\title{
La Religión
}

\section{del Imperio de los Incas}

PUR

\section{J. JIJON Y CAAMAT̃O}

Individuo de número de la Sociedad Ecuatoriana de Estudios Históricos Americanos, Sncio correspondiente de la Real Academia de la Historia de Madrill, de

la Academia Nacional de Ilistnria de Bogoti, de la Sociedad

Geográfica de Lima, etc.

\author{
VOLUMEN I \\ LOS FUNDAMENTOS DEL CULTO. \\ Huacas, Conopas, Apachitas, Urcos, \\ Huancas, Machais.

$$
\text { QUITO. - ECCADOR }
$$ \\ Tipografia Y Excuadernación Salesianas
}

1919 


LA RELIGION DEL IMPERIO DE LOS INCAS 


\section{La Religión}

del Imperio de los Incas

POR

\section{J. JIJON Y CAAMAÑO}

Individuo de número de la Sociedad Ecuatoriana de Estudios Históricos Americanos, Socio correspondiente de la Real Academia de la Historia de Madrid, de la Academia Nacional de Historia de Bogotá, de la Sociedad Geográfica de Lima, etc.

\section{VOLUMEN I}

LOS FUNDAMENTOS DEL CULTO.

Huacas, Conopas, Apachitas, Urcos,

Huancas, Machais.

$$
\text { QUITO. - ECUADOR }
$$

Tipografia y Excuadernación Salestanas

1919 


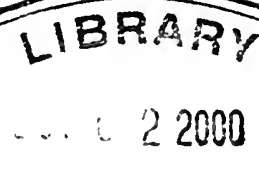


F la santa memoria de mi madre.

Paris, Febrero de 1916. 


\section{Digitized by the Internet Archive in 2010 with funding from University of Toronto}




\section{PROLOGO}

El presente volumen, es el primero de aquellos en que nos proponemos estudiar la religión del Imperio de los Incas, tal cual era al tiempo de la conquista española y como nos las dan a conocer los escritores contemporáneos, o poco posteriores al derrumbamiento de la monarquía de los sucesores de Manco Cápac.

Las creencias y supersticiones incaicas, fuéronse acrecentando a medída que se ensanchaba el Imperio, el que si impuso el culto dinástico, el del Sol y los Incas, no procuró extinguir las religiones de las naciones conquistadas sino que, muy al contrario, dejando libre curso a sus manifestaciones, procuró incorporarlas en la religión incaica. 
Así el Imperio, al principiar el siglo XVI, estaba muy lejos de presentar un aspecto religioso uniforme; era un mosaico de creencias; este mosaico es el que nosotros nos proponemos analizar.

El Imperio que estudiamos, es el que quedó formado de un modo estable, des. pués de las conquistas de Guayna Cápac, esto es, la región ocupada hoy por las Repúblicas del Ecuador, Perú y Bolivia. El N. O. Argentino, no lo consideramos parte integrante del Señorío del Cuzco, por más que los Incas hayan ejercido notable influencia y dominio sobre los aborígenes de esa región, pues nunca fue incorporado de un modo tan completo en el Imperio, como por ejemplo Quito.

Consideramos en esta obra la religión, como un fenómeno social, propio a la naturaleza del hombre y la estudiamos con criterio antropológico. Cada fenómeno religioso, lo analizamos comparativamente con los fenómenos semejantes, que se observan en otros pueblos de nuestro Continente y del Viejo Mundo, así el estudio 
de la religión incaica, es también el de los fenómenos religiosos que en ella ocurren. Al hacer las comparaciones, no pretendemos establecer relación genética entre unos ejemplos y otros; simples coincidencias de la naturaleza humana, u obra de contacto y propagación cultural, sólo nos interesan en cuanto nos dan a conocer la esen. cia del hecho religioso, que investigamos.

Cuando hayamos llegado al fin de nuestra empresa y analizado las creencias, supersticiones, ritos y cosmogonías de los súbditos de los Incas y hayamos trazado un cuadro bastante completo de los fenómenos religiosos primitivos, entónces y sólo entónces trataremos de determinar el origen de las ideas de los antiguos peruanos, acerca de lo sobrenatural:

Si alguna vez, en el curso de este libro, nos hemos referido a las creencias judaicas o a las prácticas cristianas, ha sido tan solamente a la parte formal $y$ ritual de ellas, nó al dogma, que creyén. dolo divinamente revelado, lo tenemos por extraño a las leyes evolutivas que rigen a 
IV ReLigión DEL IMPerio de LOS INOAS

los fenómenos religiosos, en cuanto son hechos humanos; mas tratando esta obra de religiones, declaramos paladinamente someter todas las afirmaciones que en ella se contienen, a la revisión de la Autoridad Eclesiástica, pues respetamos como infalibles, las enseñanzas de la Iglesia Católica.

ㅍll Autor. 


\section{CAPITULO I}

\section{LAS HUACAS}

Los historiadores del Perú, deslumbrados por el brillante culto del Sol, seducidos por las afirmaciones del Inca Garcilaso o siguiendo la corriente, ya tan marcada en el mismo siglo XVI, de atribuir a los Incas una religión monoteísta, han incurrido no pocas veces, en el error de no prestar el interés debido a otras manifestaciones de la religiosidad peruana, que, no por ser menos elevadas y poéticas, son menos interesantes, para llegar al verdadero conocimiento de la mentalidad de los indios precolombinos de esa parte de la América del Sur, ya que constituían el fondo mismo de sus creencias religiosas, la parte de ellas que, más de cerca, tocaba su sensibilidad, que más se relacionaba con sus costumbres domésticas $\mathrm{y}$ a las que por más tiempo permanecieron adheridos. Así, en los primeros años del siglo XVII, los Visitadores de idolatrías casi no Religión del Imperio de los Incas 
tienen que ocuparse del culto del Sol ni de los otros grandes dioses del panteón incaico, mientras necesitan emplear todas sus fuerzas para luchar con el culto de las Huacas, que tan arraigado estaba en el alma de los naturales; las cuales, si en muchas ocasiones, eran imágenes $y$ pinturas de diversas formas $y$ materias (1),

(1) Vro en las Indias gran curiosidad de hacer idolos $\mathbf{y}$ pinturas de dicersas materias 5 estas adoraban por dioses. Llamaranlas en el Peru Guacas y ordinariamente eran de gestos feos $y$ disformes. Acosta Historia Natural y Moral de las Indias, Serilla, 1590, pág. 323.

Al segundo genero (de cosas divinas) pertenece una infnidad que tenian de imágenes $J$ estatuas que todos eran idolos muy renerados por sí mismos sin que pasase esta simple gente adelante con la imaginación a buscar lo que representaban. Destas unas eran pintadas $y$ otras entalladas de diferentes materias formas $y$ grandeza; unas eran de plata, otras de oro, palo, piedra, barro $y$ de otras cosas; unas tenian forma humana, $y$ otras de diversos animales, peces, ares y legumbres, como de carneros, culebras, sapos, guacamayos, de mazorca de maiz, y otras semillas y legumbres, muy bien contrahechas. De las figuras de animales las mas eran de menor tamaño que sus ejemplares, porque tenian estatuas de hombres no mayores que un dedo de la mano. En esta tan grande dicersidad de idolos he notado una cosa particular, $s$ es, que los que tenian formas de animales y legumbres eran comunmente mas bien obrados é imitaban con mas propiedad lo que significaban; pero los de figura humana tenian de ordinario tan feos $\mathrm{y}$ disformes gestos, que mostraban bien en su mala catadura ser retratos de aquel en cuya honra los hazian que era el Demonio. Cobo (B) Historia del Nuevo Mundo. Serilla 1892. Tomo III, pg. 346. 
de gestos feos y deformes, para el gusto de los españoles, eran, más a menudo, objetos naturales, tales como montes, rocas, islas, fuentes, etc., etc.; a los cuales, puesto que adoraban, suponían dotados de alma y conocimiento, procediendo así por aquel estado inferior de la mente, que se designa con el nombre de animismo y que consiste en atribuir poder volitivo y comprensivo a los objetos naturales, o que, según la definición de Reinach, es la proyección al exterior de la inteligencia obscura, que obra en los salrajes y en los niños, poblando el mundo, $y$, en particular, los seres y objetos que les rodean, de vida y sentimientos semejantes a los suyos (1). Concepción primitiva que se encuentra entre los salvajes y los niños y de la cual es fácil descubrir supervivencias aun en las sociedades cultas.

El hombre primitivo no siente, como nosotros, la diferencia que le separa de los otros seres de la creación ( 2 ); bastarían, para de-

(1) Reinach (Salomon), Cultes Mythes et Religions, Tomo I, París, 1905, pg. I.

Id. id Orpheus, Paris, 1909, pg. 8.

(2) Lang (A.) Mythes Cultes et Religions, Trad. franc. par Mariller. Paris, 1896, pg. 149.

Reville (Albert). Histoire des religions, Tomo I, Paris, 1883. pg. 46 a 78 . 
mostrarlo, las ideas que, acerca del totem, tienen muchos pueblos salvajes. Mas, sin ir tan lejos, tenemos a nuestra vista y ocurren, diariamente, en nuestro alrededor, hechos de igual fuerza probatoria. ¿ Quién no ha visto a un niño dirigirse a los perros o a otros animales, y hablarles, como si éstos fuesen capaces de comprender sus palabras? i $\Gamma$ qué hombre adulto no ha hablado, alguna vez, a un perro a un gato o a un caballo? Personas rústicas hay que sostienen largas conversaciones con sus animales, que los aconsejan y amonestan cual no lıarian con un niño pequeño $(\mathbf{1}), \mathbf{y}$

Im Thum Among the Indians of Guiana, London, 1883, pg. 351 a 353 .

(1) Estos sentimientos, que, hoy dia, se manifiestan tan sólo de un modo irreflexiro o en las clases inferiores de la sociedad, se traducian en épocas anteriores, en hechos, plenamente conscientes $y$ ejecutados por la autoridad social; así en Francia, se seguía proceso a los toros que mataban a un hombre, sometiéndoles a pena de muerte. Ejemplos de tales juicios se encuentran desde el año de 1120 hasta el de 1740 , en el cual fué ejecutada, por última rez, una raca. En Grecia se seguía juicio a los animales $y$ aun a objetos inanimados, que habian causado mal a un hombre. Asi, en Atenas había un edificio, especialmente dedicado a este género de procesos, el Prytaneum «donde hierros $y$ otros objetos sin rida son llevados a prueba" (Pausanias, L. I, Cap. XXVIII). Frazer Pausanias's description of Greece, Vol. I, pg. 43, Vol. II, pg. 370 , London, 1898. No faltan ejemplos parecidos en la legislación mosaica. Asi, en el Exodo, cap. XXI, leemos: 28 «Si 
que distraen las horas de soledad en compañía de un gato o de un perro.

Igual proceder se observa, si bien con menos frecuencia, con los objetos inanimados, a los que niños y salvajes dotan de vida. Muy citado ha sido el hecho de los niños que, después de caerse o golpearse, tratan de hacer mal al objeto que ha sido causa de su dolor como si fuese el responsable $y$ quisiesen escarmentarle, para que no repitiera el hecho. Fenómeno que, menos claro y consciente, se experimenta también, en los hombres maduros, cuando, por ejemplo, arrojan al suelo el bastón con que se han golpeado, o imprecan al objeto que les ha causado dolor.

Estos hechos han sido explicados por Spencer, como derivados del culto de los muertos. Este filósofo, cuya adhesión a las doctrinas evolucionistas es bien notoria, sostiene que ya los animales superiores saben distinguir, perfectamente, los seres viros de los que no lo sou, fundándose en el morimiento que tienen por propiedad exclusiva de los primeros $\mathrm{y}$ que, por consiguiente, el animismo de los niños

un buey acorneare a un hombre o a una mujer, $y$ murieren, sea apedreado: y no se comerán sus carnes). (La Santa Biblia traducida por Scio, Barcelona, Tomo I, 1910, pg. 270). 
con respecto a los objetos inertes o es debido a pobreza del lenguaje o es causado por preconceptos de educación. Así, según este autor, la explicación del culto de piedras, montes, fuentes etc. sería necesario buscarla en el culto de los muertos, a cuyos espíritus servirían aquéllos de residencia, y el que, a su vez, sería originado por los sueños que le revelan al primitivo la espiritualidad de su alma (1).

Teoría que, además de ser muy artificial, está basada en afirmaciones, cuya verdad puede ser controvertida. En efecto, hay buenas razones para creer que los animales son animistas, en ciertas ocasiones, como cuando los perros ladran a la luna, muerden el palo o piedra con que se les ha querido herir, o cuando un caballo se espanta ante un objeto de forma singular y se resiste a pasar junto a él, aunque no haya en él nada que pudiere suscitar la idea de movimiento (2).

El animismo o naturalismo como se 10 quiera llamar, que no implica la creencia en

(1) Spencer (Herbert; Principes de Sociologie, Traảucción francesa de Cazelles, París, 1890, Tomo I, pg. 435 a 499.

(2) Reville (Albert). La nouvelle théorie évhémériste. M. Herbert Spencer.-Annales du Musee Guimet Revue de l'histoire des religions, Tomo $4^{\circ}$, Paris, 1881. 
espíritus independientes, sino tan sólo la suposición que los objetos inanimados o «son vivos, a causa de sus propias facultades, o porque son en sí poderosos»(1), debe ser explicado como un hecho primario, originado en la naturaleza de la mente humana, aúu no desarrollada, y no como un producto derivado más o menos artificial (2). Pues por extraño

11) Clodd (Edward), Animism the Seed of Religion, London, 1905, pg. 22.

(2) Más de una explicación de este fenómeno tan general ha sido formulada; pero, como no puede menos de esperarse en materia tan difícil y compleja, casi todas ellas tienen el inconveniente de ser demasiado exclusivas y simplistas y de no tener en cuenta el verdadero estado intelectual de los primitivos.

En la clásica obra de Lubbock "The Origen of Civilisation» se encuentra la teoría siguiente:

Partiendo del supuesto que los salvajes atribuyen vida a cuanto tiene movimiento, se explica el culto a las corrientes de aguas, al sol, la luna etc. Se dice que la religión de los salvajes no consiste en el profundo sentimiento del espíritu, sino en un gran temor de un mal inmediato o en el deseo de un bien próximo; que la noción que tienen de deidad es esencialmente diversa de la nuestra, pues, en lugar de ser sobrenatural, es sólo natural y se insiste en el sentimiento que podemos llamar místico, que producen las grandes selvas, las rocas $\mathrm{y}$, en general, toda comunión estrecha con la naturaleza. (Lubbock, The Origen of Civilisation, London, 1882, pgs. 285 a 287 ,

Para otros antropólogos, el animismo es debido a que, en conformidad con aquella primitiva y pteril filosofía, en la cual la vida humana parece la clave directa para la interpretación 


\section{e imposible que parezca a nuestras mentes de civilizados el atribuir vida $y$ poder a objetos}

de toda la naturaleza, la teoría de los salvajes acerca del universo refiere sus fenómenos a la acción sapiente de espiritus personales. Así, no sería el animismo producto de una espontánea fantasía, sino de una reflexión lógica de los salrajes de que no hay efecto sin causa, y la aplicación al mundo exterior del único origen de actividad que conocen, esto es, el acto roluntario. Así, todos los fenómenos de la naturaleza serían producidos por el querer de los espiritus, que imaginan residentes en sus alrededores. (Tylor, Primitive culture, London, 1891, Tomo II, pg. 109. - Goblet d'Alviella, The Conception of God, London, 1892, pg. 52. - In Animism in Hastings Encyclopaedia, pg. 535. - Hewitt, Orenda, American Anthropologist, N. S., Vol. IV, Lancaster, 1902, pg. 33).

Im Thurn, cuyas observaciones sobre el valor que los salvajes dan a los sueños son tan valiosas, opina que los primitiros, raciocinando por su experiencia $y$ en rista de que su propio espíritu, cuando sueñan, se mueve con completa actiridad, mientras su cuerpo permanece inmóvil, no se extrañan de que las inertes rocas tengan espiritu actiro. Cuando al salvaje le ocurre algún mal, lo cree originado por el objeto inerte que, inmediatamente, se lo ocasiona; $y$, cuando le sobreviene una desgracia, después de haber visto un objeto de forma extraũa, se la atribuye a éste. Cree, además, este autor que los vegetales sirven de intermedio al primitivo, para atribuir rida a las rocas, ya que, siendo inanimados, le consta viren. (Im Thum, Among the Indians of Guiana, London, 1883, pgs., 355 y 356).

Clodd propone una explicación intermedia entre las dos: Según él, "la distinción entre cuerpo y espiritu, que explica al hombre su propia actividad, era la clare de las acciones de las cosas animadas e inanimadas. Una vida y querer personal las controlaba". La concepción de rida en las cosas sin movimiento sería debida a las ideas que los primitivos tienen 


\section{inertes, es el animismo un estado común a casi todos los pueblos salrajes y se encuentra}

acerca de los sueños. (Coldd, Animism, London, 1906, pgs. 26 a 51).

En la, por muchos títulos, valiosa introducción a la historia de las religiones del Profesor Toy se halla una explicación del animismo muy interesante. En este libro se lee que las «tribus más salvajes, que nos son conocidas, miran el mundo entero, la naturaleza; los muertos, como cosa de temerse $y$, a veces, como seres a quienes se debe propiciar... Esta teoría, dados los puntos de vista de los salvajes, es inevitable. Ignorantes de lo que llamamos ley natural, no pueden ver la razón, por la cual los fenómenos de la vida, no estarían controlados por alguno de los poderes por ellos conocidos; y la fuente de estos poderes la buscan en las cosas que están en sus alrededores. Todos los objetos de la naturaleza son misteriosos para el salvaje, y llenos de movimientos y aparentes capacidades, que inducen a los salrajes a ver en ellos las causas de las cosas; $y$ como sus procederes les parecen, generalmente, semejantes a los suyos, los suponen dotados de una naturaleza parecida. Como son misteriosos y potentes, los temen y tratan de aliarse con ellos o protegerse de sus nocivos influjos». (Toy, Introduction to the History of Religions, Boston, 1913, pgs. 99 y 100).

Conceptos diferentes sobre estas materias tienen Irving King, en cuyos escritos leemos: "Oscuros como son los orígenes de la cultura, es posible... que la primera filosofia del hombre, si una concepción tan simple puede llamarse filosofia, no fué animista, esto es, no era una concepción del mundo, como movido por un número más o menos grande de agentes espirituales y conscientes. Era, más probablemente, una concepción parecida a aquella, tan general hoy, entre muchos salvajes, de que existe en la naturaleza una fuerza impersonal y semimecánica, que el hombre puede en parte usar en su provechon. King, The Developement of Religions, New York, 1910, pg. 117. 
en los países y razas más diferentes, donde no sólo se atribuyen vida y poder a piedras, árboles, fuentes, montañas y otros seres inanimados (1), sino que se los considera más poderosos que el hombre, $y$, por esto, se les rinde culto.

Ocioso e imposible sería enumerar todos los pueblos en que existen creencias animistas; pero no estará por demás recordar a la consideración del lector algunos ejemplos, a fin de demostrar la universalidad del fenómeno y precisar su significación y el nivel de cultura en que se presenta, para que, así, sea más fácil el formarnos una idea aproximada del estado de cirilización en que se encontraba Tahuantinsuyo, al tiempo de la conquista española, materia sobre la que han corrido y corren aún en el mundo científico, ideas muy lejanas de la verdad.

Los esquimales creen en espíritus del mar, de los vientos y de las nubes, y, según ellos, todo lugar, por algún concepto notable, tiene

(1) Frazer, Le Rameau d'or, Trad. Franc. de Stiebel y Toutain, Tomo III, París, 1911, pg. 5.

Reville (A.), Histoire des religions, Tomo II, París, 1883, pg. 222 .

Hastings, Encycloepedia of Religion and Ethics. Animism, Vol. I, Edinbourgh, 1908, pg. 535. 
espíritu guardián (1), de carácter malévolo, a quien es necesario propiciar, mediante sacrificios adecuados.

Gentes de este mismo pueblo, nos cuenta Spencer, atribuyeron vida a un organillo y a una caja de música, y supusieron que ésta era hija de aquel (2).

Al decir de Boas, todas las poblaciones indígenas de la América del Norte son animistas (3), y, según Dorman, el culto de los objetos naturales, tales como montañas, rocas, desfiladeros etc. etc. $y$ de todo lugar que presenta alguna singularidad, prevalece en toda la América Setentrional (4).

Afirma Jones que la religión Algonquín es un puro y cándido animismo, en el cual se adora un objeto, cuando se cree que éste

(1) Turner [L.), Ethnologie of the Ungave District, Hudson Bay territory (Smithsonian Institution $11^{\text {th }}$ annual report of the Burean of Ethnologie, $1880-90$, Washington, 1894, pg. 494.

(2) Spencer (H.), Principes de sociologie, Trad. franc. de Cazelles, Paris, 1890, Tomo I, pg. 187.

(3) Boas (F.), Second General Report of the Indians of British Columbia. Report of the $60^{\text {th }}$ meeting of the British Association for the Advencement of Science. London, 1901.

(4) Dorman, The origin of Primitive Superstitions, Philadelfia, 1881, pg, 300. Véase, también, Reville, Histoire des religions, París, 1883, Tomo I, pg. 225. 
tiene poder en potencic de hacer bien o mal, sirviendo de criterio para reconocer la presencia de esta fuerza el efecto emocional que el individuo experimenta en presencia del objeto (1).

Los iroquíes y hurones eran, también, animistas, llegando estos últimos, en este orden de ideas, hasta propiciar a sus redes de pesca, rogándoles se desempeñasen bien en su oficio; para lo que, con rariadas ceremonias, las desposaban, anualmente, con dos muchachas (2).

Los hidastas, miembros setentrionales de Ja familia Siouan o Dacota, prestan inteligencia a la sombra de los grandes árboles (3).

Los omahas, otra tribu Siouan, creen que las cosas inanimadas están dotadas de vida $y$ las suponen semejantes al hombre; así, ritualmente, llaman a las piedras «vi

(1) Jones (W.), The Algonkin Manitou. - Journal of American Folk - lore, Vol. XVIII, pg. 183, Boston, 1905.

(2) Parkman (F.), The Jesuits in North America, Boston, 1867, p. lxix.

(3) Frazer, Le Ramean d'Or, trad. franc. de Stiebel y Toutain, Tomo III, Paris. 1911, pg. 5.

(4) Fletcher (A.), A Study from the Omaha tribe. Abstracts - Proceedings of the American Association for the Advencements of Science, 1897, Salen, 1898, pg. 326 y 27. 
Fácil sería multiplicar ejemplos semejantes, buscándolos entre otras naciones de la América del Norte, tales como las que moran en la Colnmbia Británica, en el estado de Washington o en la California.

Entre los mejicanos, el pueblo de América dotado de una mitología más desarrollada, los mercaderes, reneraban al cayado, que les había serrido de apoyo, en sus riajes, el cual se transformaba entonces en Iacutecutli, dios de los caminantes (1).

Los antiguos cronistas castellanos nos han conservado la memoria de un hecho, que pone muy en relieve el animismo de los aborígenes de Cuba. El Cacique Hautes, cuando supo la resolución de Colón de pasar de la Isla Española a Cuba, juntó a su gente y le recordó las crueldades de los españoles $y$ le dijo que todo aquello lo hacían por un señor mus grande, a quien amaban mucho, $\mathbf{y}$ que le quería mostrar «sacó (entonces) una cestilla de pal" ma, en que tenía oro y dixo "Veis aquí su " señor a este sirren $y$ tras este andan $y$ como * aveys oido, ya quieren pasar acá, no preten- diendo más de buscar a este señor $\mathbf{y}$ por

(1) Sahagun. - Historia General de las cosas de Nuera España. Vol. I. - Mexico - 1829, pg. 31. 


\section{ReLigióN DEL IMPERIO DE LOS INCAS}

" tanto hagamosle aquí fiesta $\mathbf{y}$ bayles porque

" quando rengan les diga que no nos haga " mal " començaron a baçlar y cantar, hasta " que todos quedaron cansados" (1).

Según Reville, la religión naturalista o animista de la mayor parte de los indígenas de la América del Sur es de una gran pobreza de formas (2).

Los indios de la Guayana creen que el espíritu puede pasar del cuerpo de su dueño a un objeto animado o inanimado. Los brujos malévolos o Kenaima persiguen a sus víctimas en forma de jaguares o de otros animales feroces. El objeto que el paiman o curandero finge extraer del cuerpo del enfermo, sea dotado de vida o inerte, es tenido por encarnación. corpórea del espíritu del Kenaima, que entró en el cuerpo del paciente, para causarle el mal.

Estos indios dotan de alma a las plantas y a las rocas y montes; así, en la estación de verano, cuando los ríos están bajos, las piedras

(1) Herrera (A.), Historia general de los hechos de los Castellanos en las Islas, Tierra Firme y Mar Océaro. - Madrid, 1683, Tomo I, pg. 293.

(2) Reville, (A.), Histoire des religions, Paris, 1883, Tomo I. pg. 406. 
que se encuentran en el cance de éstos, en la parte que el agua las cubría, presentan una patina negra vidriosa, los indios no quieren se hable del aspecto que entonces presentan, porque creen que, avergonzadas las piedras, se irritarán y les causarán males.

En el río del Escequivo hay una piedra cariosa, que los indios no permiten nombrar y que procuran no sea vista por nadie y que ellos nunca miran.

Toda roca, de aspecto singular, la creían dotada de espíritu. La misma opinión tenían de las caídas de agua y de muchos objetos inanimados.

Los Caribes, que moraban en el río Pomerum, cuando apareció una peste de viruelas, se retiraron del lugar, cortando en el camino grandes árboles, para impedir que la peste les siguiese (1).

Los araunas tenían en su templo un dios que llamaban el Guarda, que era diez lanzas de chonta, de dos yardas de largo, muy pulidas, y cuya punta era otra pieza de madera (2).

(1) Im Thurn Among the Indians of Guiana, London, 1883, pgs. 349,354 a 56.

(2) Churche (G.), Aborigines of South America, London, 1912, pg. 146. 
Los chibchas rendían, como los peruanos, culto a todos los objetos naturales que presentaban alguna singularidad (1).

No es el animismo exclusivo de América; en el Viejo Mundo abundan ejemplos de este fenómeno.

Para los negros de Africa toda la naturaleza es animada; $y$ los fenómenos naturales, obra de un sér viro. Su incapacidad mitológica, su impotencia de concebir un organismo superior hacen que teman $y$ reneren las cosas que están a su alcance, aun las más humildes, por poco que éstas hieran su imaginación y les parezcan misteriosas, a cualquier título (2).

Los naturaies del Bajo Níger llegan, en su animismo, hasta renerar sus utensillos de cocina (3).

En general, todos los africanos del Oeste creen que un espíritu vive o puede vivir en todos los objetos notables, tales como cuevas, rocas, árboles, selvas. Estos espíritus no los consideran unidos con el objeto, pero juzgan

(1) Pedro Simón, Noticias Historiales, Bogotá, 1891, Vol. II, pg. 294.

(2) Reville, op. cit., pgs. 62 y 188.

(3) Leonard, The Lower Niger and its tribes, London, 1906, pg. 310 a 341 . 
que éste les sirve de ordinaria morada. En un punto del curso del río Ongowe hay una gran piedra, que forma una como represa $y$ dificulta la navegación: los negros creen que es el espíritu de la piedra que no quiere que pasen más allá las canoas (1).

En Asia no es más raro el animismo que en el Continente negro. Hay gentes en Siberia que tienen escasas noticias acerca de los espíritus $\boldsymbol{y}$ adoran objetos naturales, personificándolos (2).

Ciertos pueblos de la India atribuyen espíritu a infinidad de objetos inanimados, por humildes y vulgares que éstos sean; así, una mujer propicia su cesto o sus utensilios de menaje (3).

Los karens de Burma creyeron que los relojes eran seres riros (4).

De los koussa kaffirs se cuenta que, habiendo muerto uno de sus Jefes, pocos días después de liaber roto una ancla, sus súbditos

(1) Nassau, Fetichism in West Africa, London, 1904, pg. 60. Tylor, Primitive Culture, London, 1891, Vol. II, pg. 157.

(E) Reville, Op. cit., Vol. II, pg. 216.

(3) Lubbock (J.), Origin of Cirilization, London, 1882, pg. 291.

(4) Lubbock (J.), Origin of Civilization, London, 1882, pg. 289.

Religión del Imperio de los Incas 
la turieron en gran respeto, como a un sér que, habiendo sido injuriado, sabía vengarse (1).

En Polinesia, los vientos, los volcanes, las rocas, todo estaba personificado (2).

En Fidji, creen que, cuando una piedra se rompe, va su alma al mismo lugar que las de los hombres muertos. Si lo mismo acontece con una hacha u otro utensilio, su espíritu va a servir a los dioses (3).

Entre los antignos pueblos de Europa no era desconocido el animismo, del cual se notan rivas huellas en las mitologías clásicas, prolongándose la práctica de ceremonias, de él derivadas, liasta épocas en las cuales las ideas que les serrían de base, habían desaparecido. Baste recordar el matrimonio de los Dux de Venecia con el Mar Adriático.

En épocas de cultura bastante desarrollada encuentra aún el animismo expresión en ciertas teorías científicas primitivas, como la explicación que los biógrafos de Apollonius de Thyana dan de las mareas, que atribuyen a la

(1) Lubbock 'J.), Origin of Civilization, London, 1882, pg. 286.

(2) Reville, Op. cit., II, 49.

(3) Marimer, An account of the Natives of Tonga island, London, 1817, pg. 137. 
respiración del mar, $y$, hasta ahora, hablamos del seno del océano (1).

Hay quien ve animismo en laz imágenes de los poetas y en las metáforas del lenguaje corriente (2); y si, fundándose en estos modos de hablar moderno, no es posible afirmar que seamos, conscientemente, animistas; no lo es el sostener que somos capaces de serlo, como lo prueba el placer que nos causan creaciones de la imaginación, tales como las fábulas de Esopo o La Fontaine, los cuentos de Perrault u otros semejantes, que son ecos del animismo primitivo, del cual hay autores que pretenden encontrar trazas en la atribución de género a los nombres de objetos inanimados, cosa corriente en numerosas lenguas cultas, como la nuestra, el francés, etc., etc. (3).

Los peruanos no eran menos animistas que ninguno de los pueblos de que hemos hablado en las páginas antecedentes. Así, cuan-

(1) Reville, La nouvelle theorie évhémériste M. I. Spencer, Annales du Musée Guimet Revue de l'Histoire des religions, T. 4, París, 1881.

(2) Reinach (S.), Orpheus, París, 1909, pg.9.

(3) Count Goblet d'Alviella, Lectures on the origin of the conception of God. Hibbert lectures, 1891. London, 1892, pg. 53 y 56 
do un indio se quebraba o descoyuntaba un hneso, mientras duraba la curación, tenía macho cuidado el médico de ofrecer sacrificios al lugar donde tal cosa había acontecido (1). Los mercaderes ponían sebo junto a los
cestos de coca, ají, camarones n otras cosas,

(1) Otros (médicos) habia que curaban quebrados y desconcertados, los cuales tenían gran cuenta y cuidado, en tanto que duraba la cura, de sacrificar en el lugar donde se quebró o desconcertó el enfermo. Cobo, Historia del Nuevo Mundo, Sevilla, 1893, Tomo IV, pg, 137.

Esta práctica puede explicarse de dos modos diferentes: ya suponiendo que el curandero, que ofrecía sacrificios al lugar donde se había ocasionado la lesión, los hacía al lugar mismo; o que iban dirigidos al espiritu del enfermo, cuya ausencia, causa del mal, se creía producida por el golpe que lo había dejado adherido al sitio. Esta segunda hipótesis se halla farorecida por dos costumbres, estudiadas por Frazer. Entre los indios de Santiago de Tepehuacan, cuando un niño había caído de los brazos de una persona $y$ este golpe causábale una enfermedad, los padres extendían la camisa del niño en el lugar en que habia caído, y llamaban al espíritu, para que volviese a penetrar en la criatura. Hecho lo cual, recogian la camisa, con un poco de la tierra, y así se la ponían al niño.

Antiguamente, en Irlanda, cuando alguno caía a tierra, se levantaba inmediatamente, $y$, con la punta de su espada, cavaba en el lugar donde había caído, recogía un poco de tierra, diciendo que así recuperaba su alma. Mas, si del golpe se ocasionaba alguna enfermedad, una mujer, perita en tales cosas, era enviada al sitio donde se había ocasionado el daño, la cual, con determinados sortilegios, trataba de recuperar de la tierra el espiritu del enfermo. Frazer, The Golden Bongh, Vol. III, pg. 67, London, 1914. 
destinadas a la venta, a fin de obtener mayores ganancias (1).

Las mujeres invocaban al fogón y a las ollas, pidiéndoles guardarse mutuamente largos años (2).

A las ropas nuevas sacrificaban, calentándolas y untándolas con zancu, para que durasen mucho y para que su dueño no cayese enfermo (3). Es de notarse que los indios del Perú creían que las enfermedades tenían estrecha relación con la ropa.

A las casas suponían dotadas de vida, y su construcción daba lugar a que, reuniéndose los del Ayllo, se hicieran fiestas y sacrificios. Rociaban con chicha los cimientos, lo cual hacían también, al concluír el trabajo, para que no se cayesen las paredes. Adoraban la madera y la paja de la cubierta, para que da-

(1) 118 As puesto sebo junto a los cestos de coca, o de agi, o de camarones, o de otras cosas que quieres vender, para que assi tengas mas ganancia. Pérez Bocanegra, Ritual formulario e instruccion de curas, Lima, 1631, pg. 138.

(2) 102 A las mujeres se les a de preguntar: Sueles dezir al fogon a las ollas a los cantaros grandes y pequeños guardemonos bien el vno al otro muchos años adorandolos? Id. id., pg. 137.

(3) 82 En acabando de texer tus ropas, sueles las calentar: y vntar con çancu diziendo, que lo hazes para que te duren mucho y para que no caigas enfermo? Bocanegra, pg. 134. 
rasen. Oolgaban del techo mazorcas de maíz, hojas de coca y cántaros de chicha, para que sirviesen de alimentos a la nueva morada. En ciertos lugares, ponían a las casas nombres de ídolos, a los cuales dedicábanlas; $y$, mientras duraba la construcción, siempre que en ellas entraban o salían, las invocaban, Jlamándolas halcones, buitres, y rogándolas les protegiesen y se guardasen ellas, a fin de mirarlas mucho tiempo. En diversas ocasiones, relaban en su honor y las calentaban con zancu. Parece que el alma de las casas se la imaginaban en forma de un pájaro.

Antes de residir en una nueva vivienda, consultaban con los hechiceros acerca de la suerte que en ella les aguardaba (1).

(1) En hazer sus casas tenian... muchas supersticiones, combidando ordinariamente a los de su Ayllo, rocian con chicha los cimientos, como ofreciendola, y sacrificandola para que no se caigan las paredes, $y$ despues de hecha la casa tambien la asperjan con la misma chicha... en algunas partes ponen el nombre de algun Idolo a quien dedican la casa. Acosta (J.), Historia natural y moral de las Indias, Sevilla, 1590, pg. 37. 91) Cubriendo tu casa o yendo fuera de ella, o viniendo a tu casa de fuera sueles decir: A casa halcon, a casa buitre, yo y tu nos guarde muchos años fielmente y sin desdicha, y yo te guarde y mire mucho tiempo: $\mathrm{y}$ tu assi mismo guardame a mi y diziendo esto adorasla?

92 Quantas rezes as hecho velar en homra de tu casa y calentar las puertas con çancu, pg. 135. 


\section{En muchos pueblos, la casa es reverencia- da, por representar la vida de la familia $y$ ser}

101 Quando cubres tu casa sueles adorar la madera $\mathrm{y}$ la paja? y quando la acabas as colgado en ella el maiz en maçorca seca, coca, y chicha para su matalotage. Pg. 137, Bocanegra, Op. cit.

Quando han acabado de hazer la casa nueva suelen velarla. Bertonio, "Confesonario muy copioso en dos lenguas Aymara y Española. Juli 1612», pg. 252.

Entró pues aqueste enemigo (el demonio) en vn banquete qe vn Indio auia ordenado pur dar alegre contrapeso a la costa y trabajo en qe le estaua una casa que ya tenia acabada (costumbre muy recebida desta nacion, hazer grandes fiestas quando leuantan edificios,) assistio el demonio por grande rato en el banquete, con aquella forma, y figura de aue, que entro, y porque esta relacion cobrasse mas credito con los testigos, mandó el padre Prior llamar vn Indio, el qual depuso de este sucesso como quien le vido, y de su boca le oí yo por el orden que aqui refiero. Verdad es padres mios (dixo el Indio) que siendo yo muchacho, antes que esta santa Imagen estuuiera entre nosotros, vi en mi casa vn dia grande junta, y concurso de Indios congregados todos a sus bayles, $\mathrm{y}$ fiestas, $\mathrm{y}$ vi ocularmente entrar vna disforme lechuça, que se asento sobre vna pirua, o troje (donde se guarda la comida) que auia en aquella junta, y desde alli saludó a los Indios, en lengua Aymara, preguntandoles por su salud, respondieron los Indios en el mismo ydioma, y lenguage, cõ sus rudas cortesias, y cansadas sumisiones, estar buenos a su servicio. Agradecioles el aue con palabras amorosas la respuesta, diziendoles el gusto que tenia de vellos alli en semejante junta. Mas contó el Indio, que su padre suplicó a la lechuça baxasse del lugar donde estaua, $y$ se sentasse entre ellos, a hõrar aquella fiesta, y que acudio luego a sus ruegos, y entonces su madre le mãdo adorar aquella lechuça, y que en señal dello le lleuase en vu pequeño vaso (que ellos llaman kero) alguna chicha, la qual ofrenda recibio el disfraçado demonio, y con sus 


\section{Religión del IMPerio de los Inoas}

\section{necesaria a su bienestar. Por la misma razón, has pueblos que consideran sagrados los muros}

aparentes vñas de lechuça punçó tanto quanto las manos del nueuo copero, que le auia seruido a la beuida. Añidió mas el Indio, que quando sucedio esto era ya de noche, y quando con muy mezquina luz se vian los vnos a los otros, siempre este Principe de tinieblas haze en ellas sus suertes.

Es costumbre muy connaturalizada entre los Iudios, al cubrir, $y$ techar sus casas, hazer jûta de hechizeros, para que leuanten figura, $y$ pronostiquen el bien, o mal que les aguarda en aquella casa. Inuocan los demonios en su fauor, con cantares tristes, al son de tamboriles destemplados (para ellos suauissimos.) Prosiguiendo con su platica el padre Prior fray Juan Vizcayno (Religioso antiguo, y grãdemente experto en cosas de los naturales) dixo que rna vez vn Indio lleuado de curiosidad, quiso rer quien era el demonio (que de ordinario assistia en sus bayles nocturnos) y tocando sus ropas, lleno de horror, y espãto. las halló de vna lana fofa, y mojada, muy asquerosa....

Por los años de 1616 en cierta dotrina, quatro jornadas del Cuzco, vn Cazique auiendo acabado de cubrir vna casa nueua, aguardo dia, y ocasion, en que el Sacerdote que los doctrinaua, se ausentasse del mismo pueblo, y juntando en la dicha casa toda su parentela, y la mayor parte del pueblo, hizo vna gran fiesta, donde fueron muchos los bayles, y las supersticiones no pocas, renouando el vso antiguo dellos, por no auer quien le fuese a la mano, hizo repicar las campanas, $y$ tocar las chirimias: estando todos en aquestos bayles entro un aue, la qual cogio el Cazique, y cõ gran alegria quitãdose el sombrero, la puso sobre la cabeça diziendo, no me puede ya suceder cosa mala, pues mi valedor me a visitado. $\mathrm{Y}$ como gracias a Dios estan ya los mas de los Indios desengañados, y conocê que la ley Euangelica es buena, $y$ la sola, segura, y santa, no faltaron algunos de los presentes que abominaron el caso; diziendo que la aue que auia entrado en la casa, era el demonio, y assi en 


\section{que protegen la habitación y las puertas y um- brales que permiten su entrada (1). En el Cuzco, se veneraba a los caminos de Ohinchasayo y Pacaritambo; al primero se}

breue se vino a publicar en toda aquella Prouincia, hasta venir a noticia del Reuerendissimo señor Don Fernando de Mendoça, Obispo de la ciudad del Cuzco, el qual me embio comission para aueriguar el caso, y hallé el Cazique muy culpado, que siguiêdo a sus abnelos y padres, se preciaua de hechizero: $\mathrm{y}$ temeroso del castigo hizo fuga, dexando su propia patria, dãdo con sus delitos ocasion al Corregidor, para quitarle el oficio de Cazique. Ramos Gavilan, Historia del celebre santuario de Nuestra Señora de Copacabana, Lima, 1621, Cap. XXV. pg.131-133.

Estos mismos hechos los narra también Fray Andrés de San Nicolás Imagen de N. S. de Copacavana Portento del Nuevo Mundo ya conocido en Europa, Madrid, 1663, pg. 17.

Según Atienza la construcción de una nueva casa, iba acompañada de muchos sacrificios al Sol y a la Luna. Sacrificaban, en esta ocasión, venados vivos, llamas, cuyes y coca; sacando a los animales aun vivos, el corazon, el cual juntamente con la sangre ofrecian en sacrificio, comiéndose luego la carne cruda. Con la sangre mezclada con harina de maiz y coca untan las paredes para que se alimenten. Atienza (Lope). Compendio historial del estado de los indios del Peru. Este manuscrito inédito, que publicamos como apéndice a este estudio, fue escrito entre 1571 y 1574.

(1) Tylor, Primitive culture, London, 1891, Tomo I, pg• 104 a 108.

Frazer, The Golden Bough London, 1913 y 1914, Vol. II, pg. 39, Vol. III, pgs. 63 y 89.

Westermarck, The origin and developement of Moral Ideas, London, 1912, Vol. I, pg. 461 a 466.

Toy, Introduction to the History of Religrions, Boston 1913, pg. 103. 
le designaba con el nombre de Ñan, que quiere decir camino, y en una plaza, donde éste comenzaba, le ofrecían sacrificios, para que no se derrumbase ni interrumpiese (1). Llamaban Uxi al segundo, en cuyo comienzo también sacrificaban (2).

En la misma ciudad, eran consideradas como huacas las cárceles de Sancacancha, que decían había edificado Mayta-Capac (3), y la de Hurinsanca, que era dos casas pequeñas, en donde los Incas guardaban leones, tigres $y$ serpientes, $\boldsymbol{y}$ en las cuales encerraban a los prisioneros que hacían en las guerras, prisioneros que habían de permanecer en ellas una noche, sirviendo esto de ordalia, para recono-

(1) La tercera Guaca (del sexto Ceque de Chinchasuyo) se decía $\tilde{N} a n$, que quiere decir camino: estaba en la plaza, donde se tomaba el camino para Chinchaysuyu, hacíase en ella sacrificio universal por los caminantes, y porque aquel camino estuviese siempre entero $y$ no se derrumbase y cayese. Cobo, Historia del Nuevo Mundo, Sevilla, 1893, T. IV, pg. 16.

(2) La cuarta (buaca del 1er. Ceque de Cuntisuyo) se nombraba Uxi. Era el camino que va a Tampu, sacrificabase al principio del por ciertas causas que los indios dan. Cobo, Op. cit., Tomo IV, pg. 40.

(3) La primera (huaca del 8 ceque de Collasuyo) era una cárcel llamada Sancacancha que hizo Mayta-Capac, la cual estaba en el solar que fue de Figueroa. Cobo, Op. cit., IV, pg. 37 . 
cer si se habían sometido, sinceramente, a sus vencedores (1).

Sabemos también que los Incas ofrecían on sacrificio conchas de colores a una pared que tenía una barriga hacia afuera; decían haberse originado porque pasando cerca de ella un Inca había salido a hacerle reverencia (2).

(1) La segunda Guaca (del 7 ceque de Chinchasuyo) era dos buhios pequeños llamados Sancacancha el uno y el otro Hurinsanca donde tenian cantidad de Leones, Tigres culebras y de todas las malas sabandijas que podian haber. En estos buhios metian a los prisioneros que traían de la guerra, y el que moría aquella noche, comíanle las dichas fieras, y al que quedaba vivo sacábanlo. Y esto tenían por señal que tenía buen corazón y propósito de servir al Inca (Cobo IV. pg. 18.)

Como se ve debe darse muy poca importancia al ceque y camino que se señala a las huacas en la lista que de las del Cuzco se lee en la obra del P. Cobo y que es copia de la de Ondegardo desgraciadamente perdida; pues la carcel Sancacancha figura en dos ceques y caminos diferentes, sin que pueda suponerse el que se trate de dos edificios del mismo nombre, ya que la primera huaca del $8^{\circ}$. ceque de Chinchasuyo estaba en la puerta de la casa de Juan de Figueroa y Sancacancha era la segunda, lo que autoriza a deducir que estaba junto a la vivienda de Figueroa, en cuyo solar se afirma estaba cuando se nos dice pertenecía al $8^{\circ}$. ceque de Collasuyo.

(2) La segunda Guaca (del tercer ceque, de Antisuyo) era una pared que estaba junto a la chacara de Bachicao (Hernando, natural de San Lúcar de Barrameda, servidor de Gonzalo Pizarro) que tenia una barriga hacia afuera, cuyo origen decian haber sido, que pasando por allí el Inca, había salido a hacerle reverencia, y desde entonces la adoraban ofrendándole conchas de colores. (Cobo IV. pg. 25). 
En las páginas anteriores hemos hablado de huacas, I todo americanista conoce la pasmosa elasticidad de esta palabra que en la lengua corriente del Perú se emplea en tan dirersos sentidos, $r$ que designa ra a los dioses de los antiguos indios, ra los enterramientos de éstos, ra, en fin, los objetos extraídos de las sepulturas prehistóricas; por lo cual, es del maror interés para nosotros, precisar las ideas que los súbditos de los Incas expresaban con ella, pues tal conocimiento nos permitirá formarnos una idea aproximada del concepto que ellos tenían de dirinidad. Mas los escritos de los cronistas castellanos, no son sobre esta materia tan precisos como se pudiera desear 5 los datos que en ellos se contienen no son suficientes para con ellos solos determinar el rerdadero significado de la expresión huaca y sólo iluminándoles con la laz prosectada por el estadio de concepciones parecidas de otros pueblos primitiros, aquellas indicaciones al parecer contradicturias 5 faltas de unidad, recobran su verdadero significado y forman un todo.

Los cronistas, hombres de una mentalidad inmensamente superior a la de los indios, pues por adelantados que fueran éstos, pertenecían a una nación que carecía de literatura escrita; in- 
terpretaban lo que los indios les contaban no en conformidad con el espíritu de los naturales sino con el suyo; en efecto, nada hay más difícil que llegar a la justa comprensión de los primitivos, pues la mente de los civilizados, deforma casi siempre sus conceptos al reflejarlos, ya que quiere introducir claridad y lógica en donde no hay sino raguedad e incoherencia.

Condición propia de la mente humana $y$ fuente de infinitas equirocaciones es aquella tendencia que todos tenemos de aplicar a los seres exteriores nuestros sentimientos y explicar sus actos, suponiéndolos originados por los móviles que hubieran sido causa para que nosotros obrásemos de igual manera.

Así, para saber qué idea tendrían los antiguos peruanos de sus dioses, es preciso tratar de restablecer la verdad, eliminando de las afirmaciones de los cronistas, aquellos elementos que se vé han sido introdncidos por ellos y los que sólo pedemos distinguir, con certeza, mediante el estudio comparativo de ideas semejantes en otros pueblos primitivos, cuya psicología, nos es mejor conocida.

La voz mrenc, que pertenece a los lenguajes de Melanesia y Polinesia y que en Maori significa autoridad, especialmente, poder super- 
natural, autoridad divina, posesión decualidades que, ordinariamente, los hombres o las cosas no tienen (1), desde hace algún tiempo ha entrado en el vocabulario técnico de la modernísima ciencia de las religiones, para designar una concepción peculiar, que parece ser propia de un estado cultural determinado (2).

Por la palabra mana los Melanesios desig. nan no sólo una fuerza o un sér, sino también, una acción, nna cualidad y un estado. Dicen que un objeto es mana para dar a entender que tiene esta cualidad. Los hombres, los espíritus y los ritos pueden estar dotados de mana para una cosa o para otra. Mana es transmisible y puede ser comunicada, así se habla de dar mana; puede ser poseída y, como tal, dícese de un sér que la tiene. Es palabra que encierra gran cúmulo de ideas y que, en cierto sentido, corresponde a nuestras expresiones: poder mágico, cuculidad mágica, sér encantado y obrar mágicamente. Mana es lo que da valor a las cosas y a las personas. Los

(1) Tregear. - Maori.- Polynesian Comparative Dictionary (Welington, N. Z. 189, pg. 203, citado por Frazer Golden Bough, Vol. I, London 1913, pg. 228, Nota $1^{\mathrm{a}}$.

(2) Toy, Introduction to the History of Religions, Boston, 1913 , pg. 101. 
hijos de los jefes no heredan de su padre el poder, sino cuando éste puede comunicarles los cantos, piedras etc., etc., por los cuales él tenía mana, $\boldsymbol{y}$ ellos mismos no guardan su categoría, sino en cuanto establecen estar dotados de la misteriosa cualidad, cuya presencia se reconoce por algún hecho que se juzga extraordinario. Así, se asegura que cierto individuo fué recibido por jefe después de una batalla feliz, en la que tomó parte may notable siendo aún mozo. Si un hombre encuentra, por casualidad, una piedra de forma singular o con algún parecido a un producto agrícola, juzga que no es una piedra valgar y que debe estar dotada de mana; para probar lo cual, pónela junto a la planta, sobre la cual cree tiene virtud, $y$, si ésta fructifica bien aquel año, queda establecido que la piedra está dotada de esta fuerza.

Mana es ya cualidad, ya substancia, ya actividad. En primer término, es cualidad. Un sér puede estar dotado de mana, mas no lo es por naturaleza.

Es una substancia subsistente en sí, una sutil esencia, que no puede ser manejada sino por individuos dotados de ella.

Es transmisible y contagiosa. Así, si un 
melanesio llega a poseer una piedra dotada de mana, para hacer crecer los árboles, $y$ un amigo desea obtener las mismas rentajas para su hnerta, debe tomar una piedra $y$, mediante un pago equitatiro, colocarla junto a la que la contiene, $\boldsymbol{y}$ así obtener algo de ella para sí.

El mana de una piedra donde reside un espíritn, puede apoderarse de un hombre, que pase sobre ella o bajo su sombra.

Se lo representa como material $y$ se afirma que se lo re y se oye su trabajo.

Es, principalmente, nna fuerza cuyo efecto es cuanto está sobre el poder ordinario del hombre $y$ de los procedimientos generales de la naturaleza, que pertenece, especialmente a los seres espirituales, almas de los antecesores y espíritus de la naturaleza. Estos están, generalmente, dotados de mana; mas no lo tienen todas las almas de los difuntos, sino sólo las de los jefes y, principalmente, las de aquellos cuyo mana se ha manifestado en vida; así, esta idea no se confunde con la de espíritu.

Mana existe $y$ funciona de un modo independiente, $\boldsymbol{y}$ permanece impersonal junto al espíritu perconal. Fl alma de los muertos es portadora de mana; mas ella no es mana. Así, no es, necesariamente, la fuerza del espíritu $y$ 
puede ser la de una cosa material, como la de las piedras, que hacen crecer las legumbres $y$ fecundan a los cerdos, o la de la hierba, que proảuce lluvia. Pero es una fuerza espiritual, en cuanto no es mecánica, que obra sin intermedio y a distancia. $Y$ si existe infinidad de manas diferentes, parece que debe pensarse que no hay sino una sola fuerza, que se encuentra repartida entre hombres, cosas, espíritus $y$ actos.

Mana es la fuerza por excelencia, la eficacia verdadera de las cosas, que corrobora a su acción mecánica, sin anularla. Por ella la red captura los peces $\boldsymbol{y}$ las paredes de la casa son sólidas. Está desparramada en todo el mundo sensible, en el cual, aún siendo heterogénea, es inmanente. A las cosas manas se las separa de la vida ordinaria, y, a menudo, se las reverencia, lo cual, en muchos casos, hace que sean tabú; y puede afirmarse que todo objeto tabú es también mana, si bien existen muchas cosas manas que no son tabú.

Mana no es solamente un poder misterioso, sino también, una entidad subsistente; $y$, en resumen, puede decirse que es una acción sui-generis espiritual, que se ejerce a distaucia, entre dos seres simpáticos, y una suerte Religion del Imperio de los Incas 


\section{ReLIGIÓN DEL JMPERIO DE LOS INOAS}

de éter imponderable, comunicable y que se desparrama por sí mismo (1).

En Fidji, la palabra para expresar la divinidad es kalou, que significa el concepto más elevado que tienen esos isleños acerca de Dios, así como de todo sér grande o maravilloso, de toda cualidad en grado superlativo, sea buena o mala; «ustedes son kalou» es una galantería que dicen los fidjianos a los blancos, cuando estos les hablan de los triunfos de la civilización.

Para los indígenas de Fidji, ciertos pájaros, peces, plantas $y$ aun ciertos hombres, tienen conexión con kalon, el que creen que, a veces, reside en ellos.

En ciertas ocasiones, un animal se vuelve la morada de un kalou, $y$ quien lo adora debe abstenerse de comer su carne, que para él es tabú (2).

(I) Codrington, The Melanesians, Oxford, 1891, pgs. 52, 118 a 121.

H. Hubert et M. Mauss, Esquisse, d'une théorie général de la Magie. L'Année sociologique. Septiéme année 1902 a 1908 Paris, 1904, pgs. 108 a 112.

King, The Developement of religion, New York, 1910. pgs. 143 a 145.

(2) Parece que entre los animales Kolou, de Fidji y los espíritus guardianes de los aborigenes de la América del Norte liay ostrecha afinidad. 
Si bien, en ciertos casos, los fidjianos distinguen el signo material del kalou representado por él, en ótros, parece que no hacen diferencia alguna entre los dos (1).

Atua o Akua es la palabra equivalente a Dios en toda la Polinesia oriental y es distinta de las que se emplean para designar espíritu o imagen. Según un fabricador de ídolos, el poder de los hechos por él provenía de que, habiendo sido llevados al templo, se habían allí llenado de atua (2).

En la lengua malagasia de Madagascar, las voces que expresan la idea de Dios son Andrimanitra, Zanahari o Andriamanahari. La primera y la última empléanlas, comúnmente, en el interior de la isla, y la otra, en la costa.

Si se pregunta a un habitante de Madagascar el significado de estos términos, responderá que no sabe explicarlo; mas, al nombrarle sus ídolos, afirmará que son andriamanitra, añadiendo, si es más inteligente e ilustrado que la masa del pueblo, que su poder se limita a anxiliar a los hombres.

(1) Willians, Fiji and Fijians, Vol. I, The island and their inhabitants, London, 1858, pgs. 216 y 220.

(2) Ellis (W.), Polinesians researches, London, 1831, Vol.

1, pgs, 334 a 888 . 
Al genio que invocan en sus juramentos, también llaman andriamanitra, así como al Rey, añadiéndole, a menudo, el calificativo de visible (1).

Los Sakkalaros, llaman a su jefe Zanahary, que equivale a llamarle dios, y se prosternan delante de él y le veneran (2).

A todo cuanto es grande, extraordinario, valioso o incomprensible, llaman andriamanitra. Así dan este nombre a la sed, al arroz, al dinero, al trueno, al relámpago, a los temblores de tierra etc. etc. Los antecesores y soberanos muertos son tenidos por andriamanitras. Esta designación dan, también, a los libros, por su maravillosa virtud de hablar, con sólo ser ristos, ya que el significado de andriamanitra no es el de dios sino el de lo divino (3).

El terciopelo recibe el singular calificativo de hijo de andriamanitra.

Muchas de estas gentes, preguntadas quién es Dios, contestan que el sol, que las estrellas,

1) Ellis, History of Madagascar, London S. F., Vol I, pgs. $390-392$.

(2) Tan Cennep, Tabou et Totémisme a Madagascar. Paris, 1904, pg. 79 .

(3) Tan Gennep, op. cit., pg. 298. 
que la moneda o cualquiera otra cosa, a la que atribuyen gloria o misterio.

Oreen que el ciego tiene un andriamanitra ciego, que le impide ver, y el acaudalado otro rico, que le colma de bienes (1).

En Madagascar existe, además, otra expresión, que tiene un sentido más semejante aún al de mana y es hásina, voz de múltiples significados y que se aplica a hombres, a animales y a seres inertes (2).

Según los vocabularios, hásina significa virtud intrínseca y sobrenatural, que hace que una cosa sea buena o eficaz; la virtud o eficacia de un remedio; la veracidad y verdad de una palabra, o de una profecía; la santidad de una cosa; la virtud de los amuletos y encantamientos. El adjetivo másina significa; santo, santificado, potente, eficaz (3).

Un tabú no puede ser infringido sino por quien se sabe más potente, más rico en hásina que aquel que lo impuso o constituyó. Esta potencia no es la física sino la espiritual, in-

(1) Ellis, History of Madagascar, London, S. F., Vol I, pgs. 290 a 92 .

(2) H. Hubert et M. Mauss, Op. cit., pg. 113.

(3) Van Gennep, Op. cit., pg. 17. 
manente en las cosas o en las personas; de naturaleza desconocida, pero cuja existencia no puede ponerse en tela de juicio, ya que sus efectos son manifiestos (1).

Un jefe malgacho tiene hásina por haber nacido de una familia rica en hásina, $y$ por que en su beneficio han sido hechos ciertos ritos másina, por individuos másinas, brujos o parientes (2). El señor de Tananarive siendo miembro de una familia másina (3) adquiere la hásina necesaria para reinar, subiéndose a una piedra másina (4).

El hásina del jefe muerto contamina a su tumba quo se vuelve másina (5).

El hásina de un jefe es en sumo grado contagioso, $y$ el que sin estar, digamos así, inmunizado, se expone a él, podrá sufrir grares molestias, enfermedades y ann la muerte inmediata (6). No así los nobles que lo son por el hásina que poseen, para quienes el contacto con la fuerza del jefo no sólo no es

(1) Van Gennep, op cit., pg. 17.

(2) Id. id., pg. 18.

(3) Id. id., pg. 115.

(4) Id. id., pg. $79-82$.

(5) Van Gemep, Op. cit., pg. 104.

(6) Id. id., pg. 18. 
dañoso sino saludable, ya que aumenta su poder (1).

No son los fusiles de los blancos sino su hásina lo que les hace invencibles (2).

Una idea semejante es la que los malayos de los Estrechos designan con la roz kremat, que es originaria del árabe. Esta palabra, aplicada a un hombre, puede traducirse, aproximadamente, por mago y profeta; mas su exasto sentido es difícil de precisar, ya que se aplica al que predice lo futuro u obtiene cuanto desea, y a aquél cuya compañía trae buena ventura.

En 1895, una muchachita que vivía con sus padres en Singei Buru, en el distrito de Alor Gajah de Malaca, era tenida por kramat y a ella acudían gentes, venidas de distancias muy considerables, para obtener su ayuda.

Todas las tumbas de los hombres famosos ya por su santidad o por cualquier otro motivo laudable, son kramat, así como los árboles, de forma singular, y los animales dotados de alguna señal especial, tales como los tigres que tienen una pata más pequeña que las otras, o elefantes $\mathrm{u}$ otros animales albinos.

(1) Van Gennep., pg. 115.

(2) Id. id., pg. 185. 
Llámase, también, kramat a los lugares sagrados $y$ de peregrinaje, en los cuales se cumplen votos y que están investidos de un alto grado de santidad $\mathbf{y}$ son muy reverenciados.

Cada pueblo tiene dos o más kramates en su inmediata recindad $\mathrm{y}$ que son perfectamente conocidos, pudiendo ser árboles tumbas o simplemente, sitios reverenciados (1).

Entre los Jaos, moradores del Africa Oentral, la voz mulungu se aplica al espíritu hamano, después de la muerte, en cuanto se le considera habitando el otro mundo. Pero esta misma palabra tiene otra más amplia aplicación. Etimológicamente, está conexionada con la raíz kulungwa, que, en muchas de las ramas de la lengua Bantu, aparece en las formas de kulo o kuro, con los significados de grande o de viejo. Esta raíz se encuentra en la palabra kafir. Onkulunkulu, que significa a Dios, y cuya traducción literal es «el viejísimo sér» o «el grande grande sér».

La expresión mulunga en Jao se emplea para designar el mundo espiritual, o más bien dicho, el agregado de los espíritus de los

(1) Sleat (W. TV.), Malaya Magic, London, 1900, pgs. 61 a 71,153 a 165,673 y 674 . 
muertos. En varias tribus, los misioneros la han traducido por Dios; pero los Jaos no expresan con ella personalidad, sino más bien una cualidad o facultad de la naturaleza hamana, cuyo significado se extiende hasta comprender todo el mundo espiritual.

Mulungu se considera, también, como la causa de cuanto es misterioso y de todo cuanto el negro no llega a comprender, por ojemplo, del arco-iris.

Mulungu expresa la gran fuerza espiritual, el Oreador del mundo y de la vida, la fuente de todas las cosas animadas e inertes (1).

Marett, deseando precisar las ideas que, acerca de lo sobrenatural, tienen los salvajes, preguntó a Bokame, Jefe Pigmeo, que, con otros de su tribu fué expuesto en el Olimpia de Londres, cómo conocían ellos cuando una muerte era debida a oudah; obturo la siguiente interesantísima respuesta: «Si una punta de flecha o algún otro cuerpo extraño se encuentra

(1) Hatherwick (A.), Some animistic Beliefs among the Jaos of British Central Africa. The Journal of the Anthropological Institute of Great Britain and Ireland, Vol. XXXII London, 1902.

Wallace, The Nyasa Plateau. The Geographical Journal, Vol. XIII, Londres, 1899, pgs. 601 - 602. 
en el interior del cuerpo, la muerte era natural; si nada se hallaba, era porque la había causado oudah. Si un animal feroz mataba a un hombre, no era obra de oudah; mas si se cortaba, accidentalmente, los dedos, sí ». Según este pigmeo, los ruidos extraordinarios que se oyen, por la noche, en la selva y que hacen ladrar a los perros, son oudah (1).

Para los negros del bajo Níger, todas las cosas del universo, que creen son vivas, están dotadas de fuerza mística, que es la misma que la que da poder a los magos y curanderos para obrar maravillas (2).

Las ideas religiosas de los Masai, habitadores del Africa Oriental, son vagas y faltas de forma. Según Hollis, la palabra más común que ellos tienen para decir Dios es Eng-ai, que se usa de un modo muy indefinido $\theta \mathrm{im}-$ personal y se aplica a los fenómemos de la naturaleza o los seres suprahumanos (3).

(1) Marett, The Threshold of Religion, London, 1914, pg. 90 a 122.

Maret, The Tabu - mana formula as a minimun definition of Religion. Archiv für Religionswissenschaft, 1909, pg. $186-194$.

(2) Leonard, The Lower Niger and its tribes, London, 1906 , pg. 310 a 314.

(3) Hollis, The Masai, Oxford, 1905, p. XIX. 
Dice Thomson que todo lo que es extraño o incromprensible, según los Masai, tiene ngai. Así, la lámpara del explorador era ngai (1).

Los Ma-rotse creen en un dios único, omnipotente, creador del universo, al cual atribuyen todo lo que sucede, sea bueno o malo. Eiste dios corresponde al Fatum de los romanos; es el destino al cual nadie puede sustraerse. A este dios llaman Niambé, mas se le rinde escaso culto, pues se dirigen ordinariamente a los Ditino, antiguos reyes divinizados (2).

Los Bangala tiene ideas muy vagas acerca de la divinidad y con la roz ikimdu expresan una idea difícil de precisar. Ikimdu es una suerte de poder oculto y misterioso del que disponen ciertos individuos. Si un hombre se enriquece, o sus enemigos se arruinan, será a causa de su poderoso ikimdu. Esta misteriosa fuerza reside principalmente en los cálculos biliares $\mathrm{y}$ en las piedras bezares (3).

(1) Thomson, Through Masai Land, London, 1885, pg. 445.

(2) Bejuin (Eugene) Les Ma Rotse-Lausanne 1903, pg. 118 y 120 .

(3) Van Overbergh et Joughe, Les Bangala (Etât ind du Congo) Collection de Monographies ethnographiques Vol I, Bruxelles, 1907, pg. 263. 
Los Mayombes creen en un sér supremo Zambi, al que no rinden culto y del que sólo tienen una vaga idea. Zambi es lo inexplicable, la fatalidad. Lo que es misterioso dicen que es negocio de Zambi, pero este singular dios ni es adorado ni reverenciado (1).

El dios de los Wangata se llama $D z \alpha-$ Komba, fuego caprichoso e irritable; no es un dios antropoide, es impersonal y unipersonal, y nunca se manifiesta de un modo directo; es omnipresente, sin residir en ningún lugar en especial. Carece de atributos, ni da bienes, ni causa males. A reces se le ha identificado con la concepción cristiana de Dios, mas nada tiene de común con ella, ya que el concepto de Dza-Komba es el de las fuerzas imprecisas, indeterminadas, a reces contrarias, que sin cesar obran en la naturaleza (2).

Risley, cuando trató de saber cuáles eran verdaderamente las creencias de los moradores de los juncales de Chota Nagpur, llegó a la conclusión de que en la mayoría de los casos, aquel algo indefinido que ellos temen y tratan

(1) Van Overbergh et Joughe, Les Mayombe Collection de Monographies etnographiques, Vol II, Bruxelles, 1907, pg. 309 y 310 .

(2) Engels, Les Wangata, Bruxelles, 1912, pg. 80. 
de propiciar, no era un sér personal, bajo ningún concepto, y que la idea que formaba la base de su religión era la de poder o, más bien, la de muchos poderes; 5 lo que estos adoradores animistas tratan, por todos medios, de influenciar y conciliar, es la triste y poderosa compañía de fuerzas desconocidas o influencias malérolas antes que benérolas, que residen en la selva virgen, en los altos montes, en el río torrentoso, en los grandes árboles; que dan agilidad al tigre, reneno a la serpiente; que generan la fiebre de los juncales y que merodean alrededor de los campamentos, en forma de viruelas o de cólera.

No tratan de definir con mayor precisión, a quien ofrecen sus víctimas, pero su símbolo pintan de vermellón, en la estación adecuada. Existe un poder, mas no tratan de areriguar de qué clase.

En todo el Ohota Nagpur se encuentran bosques sagrados, morada de cosas indeterminadas, que no están representadas por ningún símbolo, $y$ cuyas formas $y$ funciones nadie puede indicar claramente (1).

(1) Risley, Census of India, 1901, Calcuta, 1903, Vol I, part. I, pgs. $352 \mathrm{y}$ sigts., citados por Clodd (E.), Animism, London, 1905, pgs. 24 y 95. 
Restos de concepciones semejantes parecen sobrevivir en China, en la «escuela de los letrados», en donde el Chin o Genio no es la deificación de una fuerza, sino el vago calificativo del estado sobrenatural de los seres que han adquirido una suma de virtad superior a la del común de los mortales, 5 , a menudo, es el nombre que reciben los antepasados que han tenido los honores de la apoteosis.

Para estos chinos, en la montaña, en los: bosques, en los montículos $y$ en las colinas hay chin, $y$ chin es lo que forma las nubes y desencadena los vientos. En fin, cuanto se juzga extraordinario, se designa con este nombre (1).

En la primitiva religión de los romanos, algunos de cuyos dogmas y ritos están impregnados de un carácter salvaje y que retratan la condición primitiva de Italia, cuando aún estaba escasamente poblada por bárbaros cazadores (2), encontramos concepciones primitivas, semejantes a las que venimos estudiando.

(1) Rosny (León de), Les origines du Taoisme, Annales du Musée Guimet - Revue de l' histoire des religions, Onziéme année, Tomo XXI, París, 1890, pg. 171 y 172.

(2) Frazer, The Golden Bough a Study in Magic and Religion, London, 1918, Vol I, pg 8. 
Los calendarios festivos de los Romanos demuestran que éstos, en un tiempo no conocían deidades personales; pues las que adoraban son dudosas $y$ tan faltas de claridad, que quedan enteramente subordinadas a los detalles de la ceremonia. Los ritos por ellos empieados, tienden más a evitar la malevolencia de los malos espíritus que a procurar la protección de los dioses. En los templos no se encuentran trazas de adoración a los dioses de los cuales no existían imágenes.

Las primitivas divinidades romanas no eran ni dioses naturales ni abstracciones éticas, sino tan sólo ideas sistematizadas de actividades o funciones (1).

A los Algonquines, así como a otros pueblos de América Septentrional, se ha atribuído la creencia en el Gran Espíritu, que los blancos, por una tendencia natural de la mente, conciben a manera de una persona inteligente; lo que ha sido causa del error tan divalgado de que aquellas tribus eran, hasta cierto punto, monoteístas (2).

(1) E. Agnes, R. Haigh, The religions of Greece and Rome - The Contemporary Review, Vol. XCIII, London, 1908 pgs. 35 y 36 .

(2) King, The Developement of Religion, New Tork 1910, pg. 134. 
Mas la palabra manitu de la lengua Algonquín, a la cual se ha dado el significado de Dios, es, como mana y otras muchas de que ya nos hemos ocupado y de las que luego trataremos, pertenecientes a los idiomas de pueblos primitiros, de una elasticidad e indetermiuación verdaderamente sorprendentes.

Manitu es el espíritu guardián. Los mozos, en llegando a la pubertad, se someten a riguroso ayuno, píntanse la cara de negro y retíranse, a un lugar solitario, algunos días, en los cuales el hambre y la fatiga excítanles la imaginación $\mathbf{y}$ hacen tengan viros sueños o alucinaciones; $j$ el objeto que, en este estado, se les aparece más a menudo, sea un animal o una cosa, eligen por su protector o manitu (1).

Para los Algonquines, no hay nada en la naturaleza sin manitu. Cuando no comprenden alguna cosa, la atribuyen a un genio superior, lo que expresan diciendo que es manita, roz que designa, entre los montañeses, toda naturaleza superior al hombre, buena 0

(1) Frazer, Totemism and Exogamy, London, 1910, Fol. III, pgs. 372 a 396. 
mala (1). Los hombres que tienen talentos singulares son manitus, $J$ sus grandes hechos, obra de sus espíritus guardianes.

Ios brujos persuaden a la multitud de que, por virtud de su manitu, tienen transportes extáticos, durante los cuales ren en lo porrenir (2).

Por manitu se entiende toda clase de poder supernatural, desde el más alto hasta el más bajo.

Hay manitus locales de ríos, fuentes, rocas etc., que ya son buenos, ya malos, que llenan el mundo y rigen los destinos del hombre (3), y a los cnales se hacen ofrendas. Entre ellos, opinan, sobresalen en dignidad y poder, los de los elementos, de los animales y de algunas plantas (4).

(1) P. Paul le Ieune, Relation de ce qui s'est passé en la Nouvelle France, l'Anne 1637-A Roven, MDCXXxiII, pg. 154.

(2) Charlevis, Jomrnal d'un voyage fait par ordre An Roi dans l'Amerique Septentrionale, Tome VT-A, París, MDCCXLIV, pg. 69.

(3) Parkman, (Francis), The Jesuits in North America, Boston, 1867, pg. LXIX a LXXI.

(4) Loskiel, History of the Mision of the United Brethren among the Indians in North America, London, 1791, pgs. $3 \dot{9}$ y 40 .

Religión del Imperio de los Incas 
Manitu siguifica, también, una virtud o cualidad activa.

Interrogado un algonquín, de la tribu de los Zorros, acerca de las cámaras sudoríficas y de su efecto, se explicaba diciendo que el manitu, que está en la piedra, es despertado por el calor, y que sale de ella, cuando se la riega con agna; el vapor lo conduce y lo hace entrar en el cuerpo de aquél que se halla en la cámara y lo recorre de arriba hacia abajo, de un lado al otro, sacándole todo lo dañoso, $\mathrm{y}$ antes de regresar el manitu a la piedra, deja algo de su naturaleza en el cuerpo, siendo ésta la cansa del bienestar que experimenta al salir del cuarto sudorífico. Lnego opinan que manitu tiene una presencia objetiva, una realidad subsistente, annque carezca de forma; que es, además, una virtud, que puede ser transferida de un objeto físico a otro; capaz de producir no sólo efectos mecánicos, sino, también, espirituales. En caso de trasmisión de manitu, la virtud en ambos objetos es la mismá, sólo diferente en valor $y$ grado.

En un mito algonquín, se cuenta que un hombre valeroso fué capturado por sus enemigos, los cuales le mataron $y$, habiendo comido 
su corazón, reforzaron sus manitus con el del muerto.

Las leyendas sagradas sólo deben narrarse en tiempo oportuno y circuntancias adecuadas, pues evocan los manitus de los seres a quienes se refieren.

Manitu es expresión religiosa, que lleva consigo la idea de solemnidad; indica una actitud seria y trae consigo el hálito del misterio (1).

Orenda es voz iroquesa que designa la fuerza o poder mágico que los iroqueses (indígenas de la América del Norte) suponían inherente a todo cuerpo o sér natural y a todo atributo personificado, considerándola como una propiedad o actividad, perteneciente a cada una de estas cosas, y que entendían era la causa, fuerza activa o energía dinámica, origen de

(1) Jones W., The Alghonkin Manitou - Journal of American Folk Lore, Tol. XVIII, pgs. 183 a 190, Boston, 1905.

Acerca del concepto de manitu, además de las obras citadas, véanse:

King, 'The Developement of Religion, New York, 1910, pg. 134 a 138.

Fletcher, Manitu ind Hand-book of American indians North of Mexico, Vol. I, pg. 800.

H. Huber et M. Mauss, Esquisse d'une theorie general de la Magie, pg. 120. 
toda operación o fenómeno natural, de alguna manera relacionado con el bien del hombre.

Este principio hipotético fué concebido como inmaterial, oculto, impersonal, misterioso en su acción; limitado en su funcionamiento $y$ eficacia, no omnipotente; encarnable en todo e inmanente en los objetos, si bien susceptible de ser transferido, atraído, adquirido, aumentado o suprimido, por medio del orenda de las fórmulas secretas $y$ rituales provistas de major potencia.

Luos iroqueses, supusieron la existencia de una energía dinámica, para explicar las fuerzas actiras de la rida $Y$ de la natnraleza; pues conciben cuantos seres u objetos ven, como dotados de vida, y creen que sus relaciones con la naturaleza dependen del capricho de aquéllos, por lo cual es preciso conciliarlos.

El poder orenda obra místicamente; los fenómenos naturales son producidos por el orenda de sus espíritus.

El sér que causa las tempestades, lanza su orenda en forma de nubes.

Brujo es aquél cuyo orenda es de calidad superior.

El buen resultado en la caza es debido al orenda del cazador. 
Se habla del orenda de los animales difíciles de capturar $\mathrm{y}$ se lo llama fino $\mathrm{y}$ agudo.

En el juego gana quien más orenda tiene y es el orenda lo que revela al profeta los acontecimientos futuros.

Oomo la cigarra canta en el verano $\mathrm{y}$ en las horas de más calor, juzgan que la elevación de la temperatura es debida al ejercicio del orenda de este insecto.

La credencial necesaria para penetrar en el panteón iroqués, es la demostración de un poderoso orenda. Los dioses son aquellos seres con los cuales tienen más cercano contacto y a los que atribuyen orenda, de la cual creen proviene todo bienestar (1).

Wakonda (wa - kon' - da) es el término empleado por los Omaha, Ponca, Quepaw, Kansa, Oto, Misuri y Jowa, tribus de la familia Siuan o Dacota, cuando hablan del poder que creen anima todas las cosas. La palabra, según Riggs, se pronuncia wakanda, término

(1) Hewitt (J. N. B.), Orenda, and a definition of Religion Americane Antropologist New Series, Vol. IV, New York, 1902, pgs. 32 a 46.

Id. id. Orenda in Hand - pook of American indians North of Mexico, Vol. II, pg. 147 y 148. 
que algo varía en las diferentes tribus (1), y significa, para este-autor, en su diccionario Dakota, reconocer como santo o sagrado, adorar, cuando se la emplea a modo de verbo; espíritu o cosa consagrada, cuando se la usa como sustantivo; espiritual, sagrado, consagrado, mararilloso, incomprensible $\mathbf{y}$ misterioso, cuando se la adjetiva (2).

Los Siuan atribuyen a rakonda la creación y gobierno del universo; concíbenlo más bien como una cualidad que como una forma definida; así, si, para muchas tribus, el sol $y$ la luna son wakonda, no son el wakonda o un wakonda, sino, simplemente, wakonda.

El término se aplica a los monstruos míticos, al rayo, al trueno, a las estrellas, a los vientos (3). El interior de la tierra, el otro mundo, la obscuridad, son Takonda, así como los fetiches, los objetos de ceremonia, de de-

(1) Wa-kan-hdi en Santee, wakan-kdi en Yankton, Dorsey (J. O.), A Study of Siouan Cults $11^{\text {th }}$ Annual Report of the Bureau of Ethimology, 1889 a 90, Washington, 1894, pg. 366.

(2) Fletcher, Wakonda in Hand-bock of Americans indians North of Mexico, Part. II, Wasbington, 1910, pg. 397.

(3) Wakuintañka, llaman al genio del rayo. En las tradiciones de los Osages, la luna es llamada el Wakanda de la noche. Dorsey, Op. cit., pgs. 366, 376, 378 a 381, 425. 
coración, y en algunos grupos, varios animales y árboles. Para algunas tribus de las praderas, el caballo era el perro wakonda. Machos objetos naturales y lugares de carácter extraordinario recibían este calificativo (1), así como todo cuanto entrañaba un misterio, parecía milagroso, o superior al poder normal de la de las causas (2).

Dábaselo, tambión a los brujos (3); de este modo, un mago, de la tribu Omaha, hablando de sí, decía «yo soy un wakonda» (4). Así esta voz ha sido aplicada a toda suerte de entidades e ideas y usada, ya como sustantivo, ya como adjetivo, ya como verbo o advervio (5).

Las aplicaciones de esta palabra, cubren todo el vasto campo que abraza el temor y la

(1) Mc. Gee (W. J.), The Siouan indians A prelimenary Sketch Fifteenth anual report of the Bureau of Ethnology to the Secretary of the Smithsonian Institution, 1893-94, Was. hington, 1897, pg. 182.

(2) Fletcher, Wakonda in Hand-book of American Indians North of Mexico, Vol. II, pg. 398.

(3) Mc. Gee, Op. cit., pg. 182.

(4) Dorsey, (J. O.), A Study of Siouan cults 11th Annual Report of the Bureau of Ethnology, 1889-90, Washington 1894, pg. 360 .

5) $M c$. Gee, Op. cit. 
reneración. Hay muchas cosas wakondas que no son adoradas (1), pero todos los dioses están dotados de wakonda, ya que su nombre genérico es Taku-wakan (2), que significa lo que es wakan.

Wakonda significa, aunque ragamente, misterio, poder sagrado, antiguo, grandioso, animado, inmortal; mas no denota ninguna de estas cosas con presición y claridad (3).

Takonda es invisible $y$, por lo tanto, semejante a los espíritus. Los objetos percibidos en risiones o sueños, participan de la naturaleza espiritual, $y$ si hablan al que los $v e$, juzgan que acontece por el wakonda, sin que por esto lo sean (4).

Wakonda llaman al espíritu guardián que los Dakotas obtienen, al llegar a la pubertad, de un modo parecido a los Algonquines, esto es, retirándose a un lugar secreto, en donde oran $y$ asunan, hasta que en sus sueños o alu-

(1) Dorsey, op. cit., pg. 432.

(2) Pond, Dakota superstitions. Collections of the Minnesota Historical Society, T. II, St. Paul, 1860 a 67, pg. 217.

(3) Mc. Gee (W. J.), Op. cit., pg. 183.

(4) Fletcher, Wakonda in Hand-book of Americans Indians Nort of Mexico, Washington, 1210, Vol. II, pg. 398. 
cinaciones se les aparezca el sér que debe servirles de guardián, durante la vida (1).

Los Dakotas creen que hay una estrecha relación entre el torbellino y wakonda, y juzgan que el primero tiene muchas cosas en común con las móviles alas de la polilla; miran a ésta como un sér misterioso, del cual emana un poder semejante al del torbellino. La polilla era tenida por sagrada, porque es muy difícil encerrarla, $y$, como el viento, imposible de capturar. Cuando un hombre pierde la lucidez de sus ideas, dicen que ha sido poseído por el poder del torbellino. $\mathrm{Y}$ creen que el búfalo, cuando antes de acometer escarba con las patas el suelo y arroja tierrra sobre sus lomos, imita al torbellino, para adquirir su poder. Para expresar el vigor del oso, dicen que tiene la fuerza del remolino de viento, si bien opinan, también, que es él quién lo rige. Cándidas y vagas son estas ideas, mas revelan el modo como estos indígenas imaginan el wakonda, que, según ellos, tiene adecuada encarnación en el torbellino, que es el poder

(1) Frazer, Totenism and Exogamy, Vol, III, Londres, 1910, pg. 396 a 406. 
más perfecto que conciben, ya que es intangible, incapturable, invisible $\mathrm{y}$ destructor (1).

Wakondagi es palabra compuesta de wakonda y gi, signo de posesión; se emplea, hablando de los niños, cuando principian a ca. minar, y de las primeras palabras que éstos pronuncian; mas no cuando se trata de un enfermo que, habiendo perdido la facultad de andar o la de hablar, las recobra (2).

Se dice también de los hombres, por algún concepto admirables, por ejemplo, de los brujos; significa, asimismo, un monstruo subterráneo o acuático, mencionado en los mitos; y más comunmente, se usa como adverbio, para manifestar admiración (3).

Los Omahas, tribu perteneciente al grupo Siuan-Dakota, creían que todas las cosas animadas $\theta$ inanimadas estaban dotadas de una vida continua $y$ no interrumpida. La idea que acerca de esta vida se formaban, si bien com-

(1) Wissler, The Whirlwind and the Elk in the Mithology of the Dakota. Journal of American Folk-Lore, Vol. XVIII, Boston, 1905, pg. 258 y 259.

(2) Fletcher, Wakonda in Hand-book of Americans Indians North of Mexico, Washington, 1910, Vol II, pg. 398.

(3) Dorsey, (J O.), A Study of the Siouan cults 11 th Annual report of the Bureau of Ethnologic 1839 -1890, Washington, 1894, pgs. 360 y 367 , 
pleja, parece que estaba dominada por la concepción de un poder voluntario, al cual llamaban wakonda, si bien no hay señal de que lo hayan concebido como un solo espíritu.

Entendido wakonda como la vida inmanente, manifestada en todas las cosas, y desarrollándose este concepto, sufrió una antropomorfización singular, ya que daban caracteres humanos a todas las cosas, rocas, árboles etc. etc.; $\mathrm{y}$ aunque teniéndolas por diversas del hombre, creíanlas unidas con el lazo sutil de una vida común; por lo cual juzgaban que podían darse mutaa ayuda, prestándose el socorro de sus poderes especiales, del mismo modo que el hombre puede auxiliar a sus semejantes.

A wakonda dirigían los Omahas oraciones y trataban de adquirir su favor, mediante sacrificios y actos de reverencia; lo cual demuestra que lo concebían como inteligente y capaz de oír y acceder a sus ruegos. Mas todos estos conceptos eran sumamente vagos $y$ se diluían en una admósfora misteriosa $e$ indefinida (1).

(1) Fletcher, A Study from the Omaha tribe-Abstracts Procedings, of the American Association for the Advencemet of Science, 1897, Salan, 1898. pg. 328. 
Entre los Hidastas, otra triba de los Siuan Dakota, que vive en el Misuri superior, la roz mahopa o mahopa-ictias so emplea on el sentido que manitu, orenda, wakonda, entre otras parcialidades indias, $\mathbf{y}$ a menudo ha sido traducida por Gran Espíritu.

Los Hidastas la usan, al hablar de Itakaté, dios muy reverenciado, cuyo nombre significa viejo inmortal, y de cualquiera cosa de la naturaleza, al parecer maravillosa o sagrada.

Matthews dice haber oído a ancianos Minetaris muy conservadores, emplear la palabra mahopa en el sentido de una influencia o poder superior a todas las cosas; pero sin inplicar ninguna idea de personalidad.

Usase, también, para indicar encantamiento, conjuro $\mathrm{y}$ medicina, $\mathrm{y}$ con este sentido aparece en los diccionarios (1).

Fletcher and la Plesche, The Omaha Tribe 27 th Annual Report of the Smithsonian Institution, $1905-1906$, Washington 1911, pg. 597.

Id. id., Wakonda ind Hand-book of American Indians North of Mexico, Washington, 1910, pg. 397 a 398.

(1) Mattheus (W.), Ethnography and Philology of the Hidasta Indians - Departement of the Interior Unitet States Geological and Geogrophical Survey Miscelaneus publications, No. 7, Washington, 1877, pgs. 48 y 184. 
Los Shide Pawane expresan la idea que venimos estudiando con las palabras paruxti y waruxti. En una de sus leyendas, se dice que la estrella brillante se apareció a los primeros hombres y les advirtió que se acercaba el tiempo en que les entregaría un paqueto paruxti, 5 que en cualquier lugar en que estuviesen, tendrían las cosas en él contenidas. Estas no se las daría directamente, sino que poniéndolas en la tierra, se les facilitaría el encontrarlas.

Paruxti se emplea, a veces, como sinónimo del dios del trueno; pero, refiriéndose, como en el caso anterior, al paquete misterioso, debe ser traducido por "lo maravilloso encerrado» o también el poder misterioso. Paruxti se emplea también en contraposición a waruxti, que significa la fuerza mágica, en cuanto derivada de fuentes terrenas mas bien quo celestes. Todas las cosas de la tierra, que no son fácilmente comprendidas, son tenidas por waruxti. Así puede decirse que, cuando se emplea la palabra paruxti, es con relación al relámpago $u$ otras fuerzas misteriosas del cielo, y que provienen de Tirava o de otros dioses, mientras waruxti puede decirse de un pase de manos del brujo o de los 
hechos misteriosos de cualquiera criatura, hombre, animal. Estas dos palabras han sido de ordinario, traducidas por Dios (1).

Los Tawana o Klallan, moradores del Estado de Washington, emplean, al parecer, Ja palabra thamanous, perteneciente a la germanía Chimook, en un sentido semejante al de mana, orenda etc. etc. Thamanous es un sustantivo y, como tal, se refiere a cualquier sér espiritual, bueno o malo, más poderoso que el hombre $y$ menos que Dios o el Diablo. Se nsa, también, para expresar el ejercicio de cualquier influjo sobre estos espíritus, por medio de encantamientos.

La palabra es también, un adjetivo, empleándosela entonces para designar a todo sér en el cual se cree que mora un espíritu; así se habla de una casa thamanous, de hombres thamanous. Es también un verbo y, en este sentido, equirale a rerificar los encantamientos necesarios para influir en los espíritus.

Creen que thamanous reside en un palo, en una piedra o en las aguas.

(1) Dorsey, Traditions of the Skidi Pawanee Memoirs of the American Folk-Lore Society, Vol. VIII, Boston, 1904, pgs. 9 y 331. 
A los espíritus guardianes llámanlos thamanous $y$ son ordinariamente animales, y los obtienen de un modo análogo al empleado por otras tribus americanas, de las cuales ya hemos tratado (1).

Quizás los indios Thompson, que hablan un dialecto Salish, tienen concepciones semejantes a las que hemos pasado revista en las páginas anteriores.

Estos indios creen en la existencia de innumerables seres misteriosos. "Los misterios de la tierra» son los espíritus de los picos de las montañas; en los lagos y cascadas viven los espíritus de las aguas.

Las oraciones y prácticas de los Thompson están fundadas en la creencia de que la naturaleza está impregnada de espíritus; suponiendo poseídos por fuerzas misteriosas a las

(1) Eells (Rev. Myron) The Tranä Chemakun and Killan indians of Washington territory - Annual Report of the Board of Regents of the Smithsonian Institution for 1889. Part I Washington 1899, pgs. 672 a 974 . Según Boas, la palabra sería it' a-ma'-noas, y significaría sér dotado de poder. sobrenatural, y no equivaldria a orenda ni a manitu, y no designaria el poder místico. Boas, Thamanous in Hand-book of American Indians, Tomo II, pg. 681. 
estrellas, a los montes, a los árboles y a los animales (1).

Sus recinos y parientes, los Lilluet, opinan que los animales, las plantas y las personas tabu, tales como las muchachas adolescentes, las mujeres menstruadas, los huérfanos y viudos eran poseedores de un poder sobrenatural (2).

Los Kwakiult obtienen sus espíritus guardianes mediante baños $y$ ayunos, $y$ eligiéndolos entre cierto número de patronos, que son hereditarios en su clan (3). La idea que de ellos se forman corresponde a la que los Algonquines tienen de manitu. $\mathrm{El}$ obtener los dones mágicos de estos espíritus se llama $7 o^{\prime}$ kioala y la persona que los ha obtenido es maní-alakin o sobrenatural, lo cual es también calidad del espíritu (4).

(1) Teit, The Thomson Indians - Jesup North Pacific expedition, Vol. I, New York, 1898 a 1900, pg. 344 .

(2) Teit, The Lillooet indians Jesup North Pacific Expedition, Now York, 1909, Vol. II.

(3) Frazer, Totemism and Exogamy, London, 1910, Vol. III, pgs. 433 a 436 ,

(4) Boas, The Social organisation and secret Societis of the Irwakiult indians-Annual report of the Board of the Smithsonian Institution, 1895, Washington, 1897, pgs. 393 a 396. 
La religión de los Tsimshian es una adoración al ciclo, que llaman lepre' $y$ juzgan ser una gran deidad, que tiene muchos intercesores llamados neqno'q.

Cualquier objeto natural puede ser neqno'q, palabra que designa todo lo misterioso; ya el deseo supernatural de las deidades, ya el silvido especial que usan en las danzas rituales, y que es tenido en perfecto secreto, ya un nuevo pase de manos etc.

Para estos indios, como para los demás aborígenes de la Colombia Británica, toda la naturaleza es animada, y el espíritu de cualquier sér puede volverse genio guardián de un hombre, el cual obtiene así poder sobrenatural. A estos espíritus llaman yek los Tlingit, nepno'q los Tsimshian (1).

Los Lku'ñgen, creen que los animales, así como los espíritus de los objetos inanimados, pueden volverse genios de los hombres, que así, adquieren virtudes extraordinarias.

Una concepción particular es lit do stlé, lek- $(c m$, que lo mismo significa el genio pro-

(1) Boas, First General Report on the Indians of British Columbia. Report of the Fifty Xinth Meeting of the Britisl Association for the Adrancement of Science. Held at Newcastle - upon Tyne in 1889, London, 1390, pgs. 848 y 819. 
tector del hombre, como equirale también al poder que obra contra él, $\boldsymbol{y}$ parece designar toda relación entre el hombre $y$ la energía sobrenatural.

Ciertas cosas son tabus para determinadas personas, porque esos objetos son stlā'lekam contra ellas ( 1 ).

Los Denes de Alaska y del Noroeste del Canadá, creen en una especie de divinidad impersonal indefinida. Sus ideas no son panteistas, mas tienen mayor semejanza con las de este sistema filosófico que con la concepción de un dios individual. Se la representan como casi coexistente con las fuerzas celestes, y tiénenla por la causa de la lluvia, de las nubes y de otros fenómenos semejantes. La llaman yutoere, palabra que, en Carrier, significa lo que está en alto, y su culto consiste más bien en ritos propiciatorios que en adoración propiamente dicha (2).

(1) Boas, Second General Report of the Indians British Columbia. Report of the Sixtieth Meeting of the British Association for the Adrencement of Science. Held at Leeds in 1890, London, 1901, pg. 580.

(2) Mrorice (A. G.), The Western Dénés Proceedings of the Canadian Institute, Third Series, Vol VII, Toronto, 1889, pg. I57. 
Dejando las heladas regiones de la América Septentrional, encontramos, al Sur de los Estados Unidos, la tribu de los Chickasaw, perteneciente al grupo lingüístico llamado Muskhogean, en la cual se emplea la roz híllo en idéntico sentido que las voces wakan, orenda, paruxti, en Siuan, Iroquí o Pawni (1).

Las voces zemi, chemi o semi son las que, en idioma antillano, sirven para designar a los dioses, a sus imágenes o símbolos, a los hnesos de los muertos y a cuanto se considera dotado de poder mágico; $\mathrm{y}$ estas designaciones se aplican, igualmente, a la virtud sobrenatural de la luna como a la de los antecesores de un clan.

Los Caribes llamaban a sus magos o sacerdotes eeci-semi; el nombre del tabaco era el de decemi, evidentemente refiriéndose a sus virtudes, que tenían por mágicas. A Colón, a quién tenían por sobrenatural, lo llamaban guami quemi, o sea señor o dios de las aguas (2).

(1) Speck, Notes on the Chickasaw Ethnologie and Folk Lore, Journal of the American Folk-Lore Society, Vol XX, Boston, 1907, nota a la página 57.

(2) Fewkes (Jesse Walter), The Aborigines of Porto Rico and Neighboring islans 25th Annual Report of the Bureau of Ethnology, 1903-1904, Washington, 1907, pg. 64. 
En México y Oentro América, la palabra naual ha designado el espíritu guardián de los indios $\mathrm{y}$ asociádose con las ideas de magia $\mathrm{y}$ poder sobrenatural $\mathrm{y}$ habilidad; así, en mexicano, ncutelli, significa brujo, mago o encantador; nauctl, hábil, astuto, superior o cosa que suena bien, como una campana; nututlata el intérprete; nauatilli, la les o costumbre; nanatile, tener autoridad o mandato para ejercer algún oficio (1).

Los Mayas del Yucatán llamaban naual o nautlal una danza que fué prohibiba por los misioneros.

En Quiché, naual es brujo o mago; naualin, predecir fortuna, decir la buena ventura; quinauatin, sacrificar, ofrecer sacrificios.

$Y$ Brinton cita el rocabulario Cacchiquel de Cobo, escrito en 1651, que dicho autor consultó manuscrito, en donde se dice que en Cacchiquel se llamaba puz o naucl a la magia o nigromancia, a los magos y brujos, a ciertas plantas, rocas, árboles y otros objetos inanimados, por los cuales el diablo hablaba, y a los ídolos que adoraban. La vida del árbol, de la

1) Molina, Vocabulario de la lengua Mexicana y Castellana-México, 1571, H. 63 vuelta. 
colina, etc. era su naual, porque creían que estos objetos tenían vida.

De los capitanes, esto es, de los más valerosos, opinaban que hacían naual con sus armas. Tin nahulih peri puvak equivale a $\dot{z}$ puedo, acaso, hacer milagros? (1).

A los animales feroces, llamaban en Honduras nauales, que da tanto como decir guardadores o compañeros. Cuando moría su naual, moría el indio. Para obtenerlo «íbase el indio al río, monte, cerro o lugar más escondido, convocaba los demonios, por los nombres que le parecían, hablaba con los ríos, piedras y montes: decía que iba a llorar para tener lo que sus padres tuvieron, y llebaba algún perro o gallo, que sacrificaba, $y$ con aquella tristeza se dormía, $y$ en sueños o despierto, veía algunos de los sobredichos animales o pájaros, y entonces le pedía que le diese ganancia en la sal, cacao o en otra cualquiera cosa, y de. rramaba su sangre de la lengua, de las orejas y de otras partes del cuerpo, y luego hacían su pacto con el tal animal, el cual le decía

(1) Brinton (S. G.), Nagualism. A Study in Native American Folk - Lore and History. - Philadelphia 1894, pgs. 27, 28 y 67. 
en sueños o estando despierto: tal día irás a casa, y el primer pájaro o animal que vieres seré yo que seré tu naual y compañero en todo tiempo» (1).

Concepciones análogas a las que renimos estudiando, es posible existan entre otros pueblos, ya que a nadie se le oculta cuán difícil es conocer la mentalidad de los primitiros. Mas basta la larga enumeración contenida en las páginas anteriores, para demostrar que en numerosos pueblos, cuya cultura se encuentra en un estado rudimentario (2), existe la creencia en un poder o cualidad misteriosa cuya compleja naturaleza se puede determinar diciendo:

I. Que es una fuerza productura de cuanto es extraordinario, propia de los espíritus de la naturaleza; a veces, del alma de los muertos, de los hombres y de las cosas materiales; que es una sola, mas está dividida entre los diversos seres de la naturaleza, que corrobora su

(1) Herrera, Historia General de los hechos de los castellanos, efc. Década cuarta. Madrid, 1730, pg. 157.

(2) En la enumeración anterior figura la escuela de los letrados en China, en la que sólo se encuentran ciertas reminiscencias de la concepción primitiva y que, por tanto, no constituye una excepción propiamente dicbr. 
acción mecánica sin anularla; que obra sin intermedio y a distancia, de un modo místico y sobrenatural, produciendo efectos psicológicos y mecánicos y que gobierna el universo.

II. Esta fuerza es un sér subsistente, una sutil esencia, que no pnede ser manejada sino por los que la poseen; a reces, material, más a menndo inmaterial $\theta$ invisible, inmanente en el mundo, encarnable en todos los seres, dotada de presencia objetiva $\boldsymbol{y}$ enteramente impersonal.

III. Que es, además, una cualidad transmisible, contagiosa y activa, que da el valor a las cosas.

IV. Que entre casi todos estos pueblos, un solo nombre sirre para designar la divinidad, toda cosa extraordinaria y la virtud que la produce, los magos y sus encantamientos.

V. Que la fuerza misteriosa hace sean sagradas muchas de las cosas que la poseen, y da poder a los magos.

VI. Que es una misma la cualidad que da poder a los dioses, a los hombres extraordinarios y a ciertos animales.

VII. Que al poder misterioso se le dirigen oraciones $y$, por consiguiente, se lo cree dotado de razón e inteligencia. 
VIII. Que la cualidad divina no es personal (1).

Vamos ahora a ver cómo la mayor parte de estas ideas existe en el concepto de huaca; para lo cual convendrá, en primer término, que consultemos los diccionarios quichuas y aymarás, y luego a los antignos escritores, a fin de precisar cómo los indígenas comprendían la expresión, $y$ el concepto que de sus dioses tenían.

En el vocabulario de Tschadi leemos: "Huaca $=$ sustantivo de múltiples significacio"nes de las cuales la mayor parte se refieren " estrechamente a la religión de los antiguos "peruanos. El significado principal es cada » representación figurada de la divinidad, la di* vinidad en sí misma, cada objeto sagrado don» de mora una divinidad, las figuras de oro, plata »o de madera sacrificadas al sol o a cualquiera »divinidad; cada templo o lugar habitado se" gún la creencia indígena por un espíritu bueno »o malo (casi en toda casa existía un lugar de

(1) Es muy interesante el estudio que, de este asunto, hace King, en su libro, The developement of Religion, en el Capítulo VI, bajo el título "Mistirious Power", pgs. 134 a 164. Asi como el de Saintyces, en La Force Magique. Du Mana des primitives, an Dinamisme Scientifique. París, 1914. 
- esta clase), las tumbas, los lugares de sepultura, * toda manifestación extraordinaria de belleza 0 " fealdad, cayo origen no se encuentra en el " curso ordinario de las cosas, por ejemplo, la * mujer que ha engendrado gemelos, el animal » que ha dado a luz dos o más gemelos, un huevo » con dos yemas; los monstruos, niños con más " dedos de lo natural, miembros deformados, le»porinos, etc.; las grandes fuentes que nacen » entre rocas; las piedrecillas de varios colores » encontradas en los riachuelos o al borde de la * mar; las torres altas de las casas, especialmente * de las comunales, las murallas de rocas escar" padas, las montañas altas. En fiu, llamaban " con este nombre los indios a la cordillera de * los Andes, las cuestas altas y pendientes $y$ "las antigüedades sacadas de las tumbas" (1).

(1) En el texto castellano de Tschudi se lee: «Nombre - de muchas significaciones, ídolo, cosa sagrada, cosa sacrificada - al Sol, como figuras de hombres, animales, de oro, plata o ma- dera, el templo, sepulcro, cosa extraña, nada común, sea her- mosa o fea; mujer que pare dos mellizos, huevo de dos yemas, - monstruo, fuentes caudalosas, piedrecillas de varios colores, - torre alta, cuesta muy alta, la cordillera del Perú. Tschudi Die Kechua sprache. Vol II, Wien, 1853.

"Huacca =idolos, figurillas de hombres y animales que \trayan consigo». González Holguín, Vocabulario general de la lengua de todo el Perú, llamada lengua Quichua o del Inca. En la ciudad de los Reyes. Año MDCVIII, pg. 158. 


\section{ReLigión deL JMIPERIO De LOS INOAS}

\section{En el diccionario de Holguín (1) figa- ran las siguientes frases, cuya consideración conviene al fin que nos proponemos.}

«Huaca = ídolo, adoratorio o cualquier cosa señalada por la naturalezas. Arte $y$ vocabulario en la lengua general del Perú. En los Reyes, por Francisco del Canto 1614, pg. 109. Este libro no está foliado.

«Huaca =idolos, Torres Rubio, Arte de la lengua quichua. Lima, 1619. Vocabulario quichua-español, pg. 6.

- Huaca =idolo, cosa extraordinaria, fuera de lo común , Torres Rubio, Arte y rocabulario de la lengua quichua, Lima, 1700. Torres Rubio y Figueredo, Arte y vocabulario de la lengua quichua Lima 1751 , fl. 87 vuelta.

«Huaca = A word of many signification Idol; temple; sacred place; tomb; figurs of men animals and hill . Markhan, Contributions towards gramer and Quichua dictionary, London, 1864, pg. 123.

«Huaka = todo objeto sagrado, sobrenatural o sólo extraordinario; se refiere a cosas muy distintas, templos, sepulcros y lo que contienen, momias, antigüedades, idolos, cerros altos y peñas, animales grandes, monstruosidades etc." Middendorf, Wörterbuch des Runa Simi order der Keshua Sprache, Leipzig, 1890, pg. 413.

«Huaca =idolo, cosas sagradas, sepulcro, extraño, raro, singular, nada común (sea hermoso o feo) Grim, La lengua quichua, Dialecto de la República del Ecuador. Eriburgo de Brisgovia, 1896, pg. 16.

«Huca $=$ ganado vacuno.

:Huaco $=$ colmillo.

«Huako=objeto encontrado en los sepulcros de los gentiles, como ollas, cántaros etc." Arte y diccionario Quichua-Español corregido y aumentado por los R. R. P. P. Redentoristas, al que publicó Holguín. Lima 1901, pgs. 118 y 119.

(1) González Holguín (Diego), Vocabulario de la lengua general de todo el Perú, llamada lengua Quichua. En los Reyes, MDCVIII, pgs. 159 y 160. 
"Huacca, o huaccalla llampu (1) llampulla =persona o animal manso doméstico, suhjeto.

«Huacca, huacca soncolla $(2)=$ el bien acondicionado, no ayrado.

* Huacca padremcay=dizen del padre (cura) bien intencionado.

*Huaccayan o Huaccachan = irse amansando y ablandando la condición.

«Huacca chascca, (3) collque (4) o ylla (5) = la plata escondida debaxo de tierra.

«Hacca collqueta churarini $=$ guardar plata, atesorar.

«Huacca cheecta (6) cinca, (7) o checta virpa $(8)=$ hombre de nariz partida o labio bendido.

"Huacca huachasca, (9) yscas (10) huachas$c a=e l$ varón o la hembra nacidos de un parto,

(1) llampu = blando, suave, benigno, Middendorf, Op. cit., pg. 524 .

(2) sonko $=$ el corazón, el estómago, Op. cit., pg. 784.

(3) ch'aska =desarreglado, erizado, radioso. id.id., pg. 381.

(4) kollke = plata, dinero. id. id., pg. 246.

(5) illa = piedra besar, amuleto; viejo, largo tiempo guardado. id. id., pgs. $85,86$.

(6) ch'jta = cosa partida. id. id., pg. 385.

(7) senka = la nariz. id. id., pg. 768.

(8) huirp'a = el labio. id. id., pg. 465.

(9) huachay = parir. id. id., pg. 415.

(I0) iscai = el número dos. id. id., pg. 96. 
y el rarón, ttira (1) o ylla, y la hembra hahua (2) o vispa (3).

*Huaccao, runa (4) = carnero o cualquier bestia monstruosa que tiene mas o menos micmbros o fealdad natural.

«Huacca puma (5) runa $=$ cuando tiene seis dedos en manos $y$ pies como león. *Huaccap ñan (6)=paso o lugar peligroso. «Huacca punco $(7)=$ el desdentado, mellado por baldón, o cassa (8) quiru (9).

En otros léxicos figuran además las siguientes expresiones.

«Huak'a runa $=$ un loco.

"Huak'a - yay $(10)=$ volverse loco $(11)$ »

(1) t'iray = arrancar de raiz, sacar arrancando. Middendorf, Op. cit., pg. 852 .

(2) huahua = criatura en general, id. id., pg. 417.

(3) huispa $=$ mellizos. id. id., 467.

(4) El hombre, el sér humano, id. id., pg. 735.

(5) puma = el león, id. id, pg.. 669.

(6) $\tilde{n} a n=e l$ camino, la senda, el viaje, id. id., pg. 625.

(7) puncu = la puerta, id. id., pg. 669.

(8) k'asa = la interrupción de una fila, el hueco o vacio que queda, id. pg. 247.

(9) quiru = el diente, los dientes, id., pg. 208.

(10) ya. Se pone con nombres y de ellos hace verbos incoactivos, que significan irse haciendo lo que dice el nombre, o alternando, o mudando, o convirtiendo en otra cosa, o una edad en otra etc. Mossi (M. A.), Manual del idioma general del Perú. Gramática razonada de la lengua Quichua, Córdoba, 1889 , pg. 135 y 136. 
Huacamullu = cierta jerba de comer llamada así (1).

Huacashua = carnero para carga (2).

Huacu = planta con cuso jugo se curan las mordeduras de vírora (3).

La roz huaca no es exclusiva del idioma Quichna, pues se usa también en aymara, si bien esta lengua posee otra palabra equiralente; por lo cual, parece probable que sea una de tantas expresiones que los Collas tomaron del idioma de sus recinos septentrionales. Así, leemos en Bertonio (4) «Huaca=ídolo en forma de hombre, carnero etc., y los cerros que adoraban en su gentilidad.

"Huaka, hokhse, hokhasalla (5), Llallahua $(6)=$ monstruo animal que nace con más

(11 de la página precedente). Middenfordf, Wörterbuch des Runa Simi order der Keshua Sprache, Leizig, 1890, pg. 414.

(1) Mullu = concha colorada. Middendorf, Op. cit., pg. 604.

(2) Arte y rocabulario en la lengua general del Perú. En los Reyes, por Francisco del Canto, 1614, pg. 129 y 130.

(3) Grim. La lengua quichua, dialecto de la Pepública del Ecuador, Friburgo, 1890, pg. 16.

(4) Bertonio, Vocabulario de la lengua Aymara, edición de Platzman, parte segunda, Leipzig, 1879, pg. 143.

(5) hokhasalla = Nonstruo o cosa que tiene mas o menos de lo que la naturaleza suele dar asi los hombres como los animales, id. id., pg. 140.

(6) Llallahua = Papa, o animal monstruoso, como dos papas pegadas, o como una mano, un animal de cinco o seis pies etc., id. id., pg. 199. 
o menos partes de las que suele dar la naturaleza.

* Huaka haque (1) caura (2) etc., = hombre o carnero así nacido.

«Huakachatha (3) = parir monstruo».

Semejante parece haber sido el significado de la palabra vilca. $\Lambda$ sí, remos en el mismo léxico.

*Villca $=$ el sol como antiguamente decían, y agora dicen inti...

* Villca $=$ adoratorio dedicado al sol 0 otros dioses.

* Villca: es también una cosa medicinal, o cosa que se daba a beber como purga para dormir y en durmiendo dice que acndía el ladrón que auia llenado la hacienda del que tomó la purga, y cobra su hazienda: era embuste de hechizos".

- Villaparo = mais de que suelen hacer chicha muy fuerte» (4).

El carácter nativo aymara de la palabra villca, en contraposición a la de huaka, toma-

(1) haque; varón o mujer, id. id., pg. 120.

(2) Caura; carnero de la tierra, id. id., pg. 39.

(3) Parir = Yocachatha Huahuachata. Bertonio, Vocabulario de la lengua Aymara, primera parte, Leipzig, 1879, pg. 349.

(4) Bertonio, Vocabulario de la lengua Aymara, segunda parte, Leipzig, 1879, pg. 386. 
da del quichua, está bien acentuado, por haber sido reemplazada por la voz inti, para designar el sol, cuando la penetración incaica se acentuó en el Collao (1).

Antes de pasar adelante, útil nos parece hacer observar que las frases quichuas, que acabamos de citar, demuestran, que la mansedumbre y dulzura de genio eran consideradas por los aborígenes del Perú, como cualidades apreciabilísimas y propias de la divinidad, lo cual, a nadie se le oculta, habla mny alto en pro del carácter de estos indígenas y de los elementos de civilización que poseían; pues bien sabido es por los etnógrafos, que los hombres hacen sus dioses a su imagen y semejanza.

Debe también notarse que, así como en iroquí, la palabra orenda designa el poder misterioso y el canto (2), en quichna, la expresión buaca según Atienza, «significa lugar de lloro; donde manifiestan con sollozos sus necesidades a quien ningún remedio verdadero les puede dar (3) y parece estar relacionada con huacay, que equivale a llorar, y de la que

(1) La penetración incaica no cesó con la conquista espanola, antes continuó durante largos años.

(2) Vide ut supra.

(3) Atienza, Lope. Compendio historial del estado do los indios del Perú, 
proviene huacan, que significa tocar campanas, cantar las aves, graznar, aullar, bramar, chillar de todas maneras los animales; (1) pues todos estos sonidos dicen que son el llanto de los seres que los producen (2), siendo muy de notarse que los indios peruanos acompañan siempre sus gemidos de una melodía cadenciosa y monótona, lo cual establece un punto más de contacto entre el concepto iroquí y el incaico (3).

Del estudio atento y comparativo de los cronistas castellanos se desprende que los indígenas del Perú tenían una infinidad de Huacas, y que, si había algunas en forma de animales, ótras a manera de hombres (de las cuales contaban históricas genealogías) las más eran piedras informes u otros objetos naturales.

A las imágenes o ídolos no los adoraban por lo que representaban, sino por sí mismas.

(1) Holguin, Vocabulario de la lengua general de todo el Perú, llamada!lengua Quichua. En los Reyes, MDCVIII, pg. 160.

Mindendorf, Wörterbuch des Runa Simi order der Kechua Sprache, Leipzig, 1890, pg. 410.

(2) En el Ecuador la gente inculta, hablando en castellano, dice comunmente, que llora el perro, el huiracchuro, etc. por decir que aulla, canta etc. etc.

(3) En Aymara, huaka se llama la faja de las mujeres. Bertonio, Op. cit., primera parte, pg. 413. 
A cuanto, por algún concepto, les parecía extraordinario o notable, rendían culto $y$ ofrecían sacrificios; pues creían que aquella diversidad era señal de que la cosa poseía un poder extraordinario, siendo muy de adrertir que Cobo y Román dicen que no. tenían este poder por propio de las cosas, sino por extraño a ellas, y que les había sido comunicado por la divinidad; y el anónimo jesuita, cuya relación publicó Dn. Marcos Jiménez de la Espada, sostiene que no entendían que esta clase de huacas fuesen viras, sino que juzgaban que el gran dios Illa Tecce las había creado, para que sirviesen de lugar sagrado.

A los hombres en cuyo nacimiento acontecía algo singular, como cuando nacían dos o tres de un vientre o en posición distinta de la normal, llamaban huccas, y con ellos tenían especial cuenta, para respetarlos y proveerlos del sustento necesario, diciendo que, si la naturaleza los señaló, no fué sin algún misterio; y si éstos encontrabau algunar piedra, concha o cualquier otia cosa señalada, teníanla en más que si otro cualquiera la hubiese hallado (1). lin Caxamalca de Nazca,

(1) De las supersticiones que tenian acerca de los gemelos y de los nacidos de pie, se tratará en otro lugar.

Religión del Imperio de los Incas 
tenían por huaca a un cerro grande de arena, por estar colocado entre tierras de otra calidad; en el valle de Lima, a un árbol muy grande; en todo el Perú, a las patatas n otros productos agrícolas do formas extraordinarias. Rererenciaban a los pumas, jaguares $y$ osos, por su fuerza, rogándoles no les hiciesen mal; al perro, por su lealtad; al cóndor, por su grandor; al halcón, por su ligereza y buena industria para obtener su comida; al buho, por la hermosura de sus ojos 5 cabeza etc. etc. Adoraban también a los ríos $y$ fuentes, a la tierra, al aire, al fuego; a nna llama, en las tierras en que se criaban muchas; en los pueblos ribereños, a la ballena, por su corpolencia, y al pescado que más abundaba en la región, porque decían que el primer pescado, que estaba en el cielo $y$ del cual procedían todos los de aquella especie, de que se sustentaban, tenía cuidado de enriarles a su tiempo sus hijos en abundancia $y$, por esta razón, unas provincias adoraban a la sardina, porque pescaban más cantidad de élla; ótras, a la liza, a la dorada, por su hermosura, a los cangrejos 5 langostas etc. etc.

Consideraban, también, por luaacas a los llanos que se forman on las cuestas, $;$ a los 
lugares en donde sembraban maíz para los sacrificios.

Y a cada una de estas dirinidades ofrecían sacrificios con diferentes intenciones: a únas rogaban fecundasen a las mnjeres; a ótras, les diesen salud r rida; a éstas, porque decían que de ellas salían el hielo 5 el granizo; a ésas, para que lloriese.

No sólo llamaban los indios peruanos huacas a sus dioses, sino también, a todos los lugares sagrados, diputados para oración I sacrificios; éstos eran en número infinito, pues, fuera de los adoratorios comunes $y$ generales de cada nación, había en cada pueblo muchos, $y$ aun toda parcialidad 5 familia tenía los susos particulares.

Estos templos y adoratorios, así en el Cuzco como en lo demás del Imperio, estaban esparcidos por villas, despoblados, sierras, montañas; únos en los caminos, ótros en las soledades de la cordillera; ya en tierras de sembrar; sa en helados páramos.

No todos los adoratorios eran templos o casas; porque, sitndu muchos, cerros, quebradas, peñas, fuentes $y$ otras cosas semejantes, no babía allí edificio, más de una humilde choza, morada de los sacerdotes. 
No sólo adoraban a las huacas, sino aun a los lugares en donde decían que drscansaron - estuvieron, y los llamaban Saman (1), y otros lugares, donde las invocaban, tenían el nombre de Cayan (2).

El culto a las huacas no era continuo $y$, al decir del erudito $\Sigma$ culterano escritor D'Aralos y Figueroa, no se le polía llamar adoración, sino sólo reverencia a aquellas cosas, por parecerles raras (3).

(1) Samay = resollar, respirar, tomar aliento, descansar. Middendorf, Op. cit., pg. 753.

(2) K'aiya-huata = el año siguiente; K'aya punchau = pasado mañana, id. id., pg. 286.

(3) Adorauan los Ríos, las fuentes, las quebradas, las pe. ñas o piedras grandes, los cerros.... finalmente qualquier cosa de naturaleza qe les parezca notable y diferente de las demas, la adoran como reconociendo alli alguna particular deydad. En Caxamalca de la Nasca me mostrana vn cerro grande de arene que fue principal adoratorio o Guaca de los Antiguos.... (En los Reyes) tuuimos (los jesuitas) necesidad (para fundir una campana) de leña rezia $y$ mucha 5 cortoze rn arbolazo disforme, que por su antignedad y grandeza auia sido largos años adoratorio $y$ guaca de los Indios. A este tono qualquier cosa qe tenga estrañeza entre las de su genero les parecia que tenia diuinidad, hasta hacer esto con pedrezuelas $y$ metales, $y$ aun rayzes $y$ frutos de la tierra, como en las rayzes que llaman Papas ay rnas estrañas aquien ellos ponen nombre Llallahuas, $y$ las besan y las adoran. Adoran tambien ossos; leones, tygres y culebras, porque no les hagan mal. Acosta, Historia Natural y Moral de las Indias, Serilla, 1590 , pgs. 312 a 316. 


\section{Del análisis que hemos hecho en las pá- ginas anteriores, despréndese con ovidencia:}

Adoraban Rios, Fuentes, Quebradas, Peñas, Piedras grandes, $\mathrm{y}$ las Cumbres de las Sierras, y qualquiera cosa de naturaleça que les parecia notable, y diferente de las demás... y qualquiera cosa extraordinaria, les parecía que tenía diuinidad. Herrera, Historia general de los Hechos de los Castellanos en las islas y tierra firme del Mar Oceano. Decada Quinta, Madrid, 1728, pg. 91.

De ordinario (las huacas) son de piedra y las mas veces sin figura niuguna, otras tienen diuersas figuras de hombres o mugeres, $y$ algunas de estas Huacas dizen, que son hijos o mugeres de otras Huacas, otras tienen figura de animales. Todas tienen sus particulares nombres, con que les invocan y no hay muchacho que en sabiendo hablar, no sepa el nombre de la Huaca de su Ayllo; porque cada parcialidad, o Ajllo tiene su Huaca principal, $y$ otras menos principales algunas veces, $y$ de ellas suelen tomar el nombre los muchachos de aquel Ayllo.... Y no solo reverencian las Huacas, pero aun los lugares donde dizen que descansaron, o estuvieron las Huacas que llaman Zamna y a los otros lugares de donde ellos las invocan, que llaman Cayan. Arriaga, Extirpación de la Idolatría, Lima, 1621, pg. 12.

Dos maneras tenían de templos, unos naturales y otros artificiales. Los naturales eran cielos, elementos, mar, tierra, montes, quebradas, rios caudalosos, fuentes o manantiales, lagos o lagunas hondas \&c.... todas las cuales cosas fueron por ellos reverenciadas no por entender que alli habia alguna divinidad.... p porque fuese cosa viva, sino porque creían que el gran Dios Illa Tecce habia criado y puesto allí aquella tal cosa... para que sirviese de lugar sagrado. Anónimo, Relación de las costumbres antiguas de los naturales del Perú. Tres relaciones de antigüedades peruanas, Madrid, 1879, pg. 146 y 147.

No se si puede llamarse essa adoración, (la que rendian a las huacas), porque no era mas que vna manera de reuerencia, 


\section{ReIIGIÓN DEL IMPERIO De los INOAS}

\section{Que a cuanto es extraordinario se con- sidera dotado del poder huaca, el cual se en-}

que hazian a todas aquellas cosas que en su genero les parescian raras. D'Avalos y Figueroa, Miscelanea Austral, Lima, 1602, fol. 152 .

No tienen número ni cuento las cosas que reneraban y tenian por divinas estos indios, $y$ asi no fácilmente se pueden reducir a suma. Con todo eso, reduciendolas a dos generos, digo que pueden entrar en el primero las obras de Natura$l \in z a, y$ en el segundo todas las figuras e idolos que carecian de otra significación $y$ ser mas que la materia de que eran compuestas y la forma que les dió el artífice que las hizo. Para declarar las primeras, es de saber que tuvo esta gente costumbre de reverenciar $y$ ofrecer sacrificios a cuantas cosas naturales se hallaban que se diferenciasen algo de las otras de su género por alguna extrañeza o extremo que en ellas se descubriese a lo cual se morian; por creer que todo aquello que Dios había criado con alguna diversidad de lo otro había sido con misterio porque no acaso lo señalaba y extrañaba de lo común. Yendo pues sobre este fundamento, llamaban $y$ tenían por Guaca a cualquier hombre que nacía señalado de Naturaleza, como si dos o tres nacian juntos de un rientre o con otra nota $y$ particularidad. Tenian con estos especial cuenta para respetarlos y procurar su sustento, proreyéndoles de lo que habían menester o de oficio col que lo ganasen, en que no fuese menester trabajar, diciendo, que pues la Naturaleza los señaló que no fue sin algun misterio... y cualquier cosa que a estos acaecía en sus personas o haciendas que fueso diferente que a los otros, lo atribuiau a este misterio; especialmente si hallaban alguna piedra o concha o cualquiera cosa señalada la tenian en más que si otro la hallara... Cobo, Historia del Nuevo Mundo, Sevilla 1892. Tomo III, pgs. 343 y 344.

Dicho habemos ya como a todos los lugares sagrados diputados para oración y sacrificios, llamaban los indios peruanos Cruacas, asi como a los dioses e idolos que en ellos adoraban. Destos habia tanta multitud y diversidad que no es posible 


\section{cuentra en las fuerzas naturales, en los muertos $y$ en las cosas inanimadas.}

escribirlos todos; porque fuera de los adoratorios comunes y generales de cada nación y provincia, había en cada pueblo otros muchos menores; y sin estos, cada parcialidad y familia tenía los suyos particulares....

Estos templos y adoratorios asi del Cuzco como de las otras partes del reino, estaban unos en poblado y otros por los campos sierras y montañas agrias; unos en los caminos, y otros apartados dellos; en los sembrados y tierras de labor, y en punas, y desiertos y donde quiera, en tanto numero que apenas caminamos una jornada por cualquier parte que no topemos rastros y ruinas de muchos. No todos los adoratorios eran templos y casas de molada; porque los que eran cerros, quebradas, peũas, fuentes $y$ otras cosas a este tono, no tenian casa ni edificio, sino cuando mucho un buhio o chosa en que moraban los ministros y guardas de las dichas Guacas. Cobo, Historia del Nuevo Mundo, Serilla 1893. Tomo IV, pgs. 5 y 6.

Adorauã lo qe reyan rnos a diferencia de otros sin consideraciõ de las cosas qe adorauan, si meresciã ser adorados; ni respeto de si propios para no adorar cosas inferiores a ellos: solo atendiã a diferenciarse estos de aqellos y cada vno de todos; $\mathrm{y}$ assi adorauã yeruas, plãtas, flores, arboles de todas suertes, cerros altos, grãdes peñas: y los resquicios dellas, cueuas hondas, guijarros, y piedrecitas, las que en los rios y arrebejos hallahuã de diuersos colores como el jaspe. Adorauã la piedra esmeralda particularmête en vna prouincia $q^{\circ}$ oy llamã Puerto viejo, no adorauã diamãtes, ni rubies porqe no los huuo en aqella tierra. En lugar de ellos adoraron diuetsos animales, a vnos por su fiereza como al tigre, leõ, y osso, y por esta causa teniendolos por dioses, si a caso los topauã, no huya dellos sino qe se echauã en el suelo a adurarlos, y se dexaua matar, y comer sin huyr ni hazer defêsa alguna. Tăbiê adorauã otros animales por su astucia como a la zorra, y a las monas. Adorauã al perro por su lealtad y nobleza, y al gato cerual por su ligereza. Al aue qe ellos llaman Cûtur por su 


\section{Que los poderes huacas gobiernan el unicerso, e intluyen en el mundo psicológico $y$ en el físico.}

grãdeza,.... Otras naciones adoraron los halcones por su ligereza $y$ buena industria de hauer por sus manos lo $q^{\ominus}$ hã de comer, adoranã al buho por la hermosura de sus ojos y cabeça, y al murciegalo por la sutileza de su vista, qe les causaua mucha admiraciõ $q^{e}$ riesse de noche; y otras muchas aues adorauã como se les antojaua. A las culebras grãdes por su mõstruosidad y fiereza, qe las ay en los Antis de a reinticinco $y$ de a treinta pies, $y$ mas, $y$ menos, de largo; $y$ gruesas muchas mas quel muslo. Tãbiê teniã por dioses a otras culebras menores dõde no las auia tãn grandes como ê los Antis, a las lagartijas, sapos y escuerosços adorauan. En fin no auia animal tã ril ni suzio qe no lo tuuiesê por dios; solo por diferêciarse rnos de otros en sus dioses, sin acatar en ellos deidad alguna, ni prouecho $\mathrm{q}^{e}$ dellos pudiessê esperar. Estos fuerõ simplicissimos ê toda cosa a semejãça de ouejas sin pastor. Mas no ay $q_{e}$ admirarnos $q_{e}$ gête tã sin letras, ni enseñãça alguna cayessë en tã grãdes simplezas, pues es notorio $q_{e}$ los Griegos y los Romanos qe tãto presumiã de sus ciêcias, tuuierõ quãdo mas floreciã ê su ímperio, 30 mil dioses.

Cap. X. De otra gran rariedad de dioses que tuuieron.

Otros muchos Indios huuo de dirersas naciones en aqella primera edad, que escogieron sus dioses cõ alguna mas consideración, que los pasados, porque adorauã algunas cosas, de las quales recebian algun prouecho, como los que adorauan las fuentes caudalosas, y rios grandes, por dezir que los dauan agua para regar sus sementeras.

Otros adorauan la tierra, y le llamauan Madre, porque les daua sus frutos, otros el aire por el respirar porque dezían que mediante el riuian los hombres, otros al fuego porque los calentaua, $y$ porque guisauan de comer con el, otros adorauan a vn carnero, por el mucho ganado que en sus tierras se criaua, otros a la cordillera grande de la sierra neuada, por su altura 


\section{Que la cualidad de huaca es trans- misible y contagiosa, $y$ es ella la que da valor a las cosas.}

I admirable grandeza, $\mathrm{y}$ por los muchos rios que salen della para los riegos, otros al maiz o çara como ellos lo llaman, porque era el pan comû dellos, otros a otras mieses y legum. bres, según que mas abundantemente se dauan en sus prouincias.

Los de la costa de la mar demas de otra infinidad de dio. ses que tuuieron, o quiça los mismos que hemos dicho, adorauan en común a la mar, y le llamauã Mamacócha, que quiere dezir madre mar, dando a entender, que con ellos hazia oficio de madre, en sustentarles cõ su pescado. Adorauan tambien generalmente a la vallena por su grãdeza y monstruosidad. Sin esta comun adoracion que hazian en toda la costa, adorauan en diuersas prouincias y regiones al pescado, que en mas abundancia matauan en aquella tal region, porqe dezian que el primer pescado que estaua en el mundo alto, (que assi llaman al cielo) del cual procedia todo el demas pescado de aquella especie de que sustentauan, tenia cuidado de embiar. les a sus tiempos abûdancia de sus hijos para sustento de aquella tal nasción: $y$ por esta razon en rnas prouincias adorauan la sardina, porque matauan mas cãtidad della que de otro pescado; en otras la liça, en otris al tollo, en otras por su hermosura al dorado, en otras al cãgrejo, $y$ al de mas marisco por la falta de otro mejor pescado: porque no lo auia en aqella mar, o porque no lo sabian pescar y matar. En suma adorauan y tenian por dios qualquiera otro pescado, que les era de mas prouecho, que los otros. De manera que tenian por dioses no solamente los quatro elementos cada rno de por si, mas tambien todos los compuestos, $y$ formados dellos, por ríles é inmundos que fuessen. Garcilazo de la Vega, Comentarios Reales, Lisboa, 1608, folics 9 rerso a 10 rerso.

Otros muchos barones y hembras tienen cargo de las guacas fixas de que esta hecha particular rrelacion en la carta 


\section{Que el nombre de huaca sirve para designar a los dioses, a las cosas extraordina- rias $y$ a los templos.}

general del Cuzco, ques común en todo el rreyno e contiene todos los lugares que se diferencian de los otros en algo alderredor del pueblo hasta las cumbres, si es tierra aspera que llaman estos apachetas, como algunas piedras grandes e todos los puquios y nasçimientos de agua, o algunos llanos que hacen en alguna questa, o algunos arboles señalados, ó las partes aonde siembran el mayz para los sacrificios; porque todas estas cosas estan divididas por sus ceques e rrayas en el torno de cada pueblo y estan a cargo de personas que hagan en ellas sacrificios diferentes e para diversos hefetos; en unas para que se empreñen las mujeres, en otras que dizen que de alli sale el yelo o el granizo, $y$ en otras que llueva; ansi desta manera les enseña el Inga esta diuision de lugares en todo lo que conquisto, hechandoles grandisimo cargo del reneficio que rrescivian en darles noticia a cada vno en su tierra de lo que tenyan e se podían aprovechar para sus necesidades; lo qual el dia de oy hacen por su mysma horden y tienen señalada gente que entiende en ello; e si es nesçesario en todos los pueblos hacerles que pinten la carta, $S$ viendo la del Cuzco luego lo hacen, que al sacerdote le quede noticia de cada cosa de aquellas en particular, ansi para la que entienda $y$ haga castigar, como para predicarles contra ella $y$ moverlos con raçones claras a que entiendan las yllusiones y enganos del demonyo; ques negocio que por ser general ba muncho en el y es gran fundamento para su edificacion e combersión. Ondegardo, Relación de los fundamentos del nutable daño que resulta de no guardar a los Indios sus fueros. Documentos del Archivo de Indias publicados por Torres Mendoza, T. 17, Madrid 1872, pgs. 85 y 86.

Comrn es a casi todos los Indios adorar Huacas, Idolos Quebradas, Peũas, o Piedras grandes, Cerros, Cumbres de montes, Manantiales, Fuentes, y finalmente qualquier cosa de na- 


\section{Que el carácter de huaca hace que se considere a muchas cosas como sagradas.}

turaleza que paresca notable y diferenciada de las demas. Acosta (?) Instrucción contra las ceremonias y Ritos que usan los Indios. Confesionario para los Curas de Indios. Sevilla, 1603, fol I.

Eran mas superticiosos los del Perú qe los de nueua España, porque si veian alguna peña, o roca, o un gran guijarro que se diferenciaua en algo de los otros, estauan persuadidos que era cosa diuina, y que los dioses hauian puesto en el algo de su deidad. Román y Zamora, Las Repúblicas del mundo, Tercera parte, Salamanca, 1595, fl. 129 v.

$Y$ lo que supongo es que fueron tan ciegos los Indios en su gentilidad que pualquiera cosa de que pudiesen esperar algun bien, o temer algun mal, la adoraban por Dios y idolatraban en ella, y assi adoraban hasta los animales por brutos $y$ crueles que fuesen, $y$ quanto mas crueles $y$ ponçoñosos era mayor la adoracion que les hacian como a Tigres, Osos, Leones, Culebras y Serpientes. Tenian infinidades de idolos, hechos de metales de la tierra. Huacas que son cosas señaladas y notables, como Cerros muy altos, Apachetas que son obras. Piedras grandes que el diluuio dexo en partes donde no se pudo jusgar de donde rodaron. Fuentes manantiales; a qualquiera cosa de estas insensibles adoraban por Dios.... Y la misma (veneración) tienen quando alguna criatura en su nacimiento sale señalada y assi en entrando en edad los mas destos dan en hechiceros, sortilegos y adiccionos; y quanto mas lisiado fuere uno destos le tienen y veneran por mayor hechicero.... (Adoran) tambien a los lugares donde an estado y a sus mismos nombres y apellidos pues, a los lugares donde estubieron, llaman Zamama que significa descanso y otros lugares de donde ellos las invocan llaman cayan tambien las reuerencian. Oliva, Historia del Perú, Lima, 1895, pgs. 130, 131 y 133.

2. Si an tenido, ó tienen huacas, ó idolos publicos, ó particulares, ó si los an mochado, ó adorado, ofreciendoles sacrifi- 
VI. Que la cualidad que da poder a los dioses, la tienen los locos y todos los hombres dotados de alguna singularidad.

VII. Que a las huacas se dirigen oraciones, y que la cualidad divina parece no ser personal.

VIII. Que huaca es encarnable en todos los seres de la naturaleza.

Todo, pues, nos autoriza a clasificar el concepto de huaca, en la misma categoría que el de mana, manitu etc., sin que por esto pucda decirse que sea enteramente igual a éstos, ya que las condiciones económicas y sociales en que se encontraban los Peruanos (1) antes de

cios, ó haciendo algunos ritos, ó supersticiones, pidiendoles rida, salud, ó otros bienes temporales.

16. Si an adorado, ó mochado, adoran o mochan algunos cerros, ó manantiales, ó puquios, pidiêdoles vida, salud, ó otros bienes têporales. Villagómez, Carta pastoral de Exortación contra las idolatrías del Arzobispado de los Reyes-Lima, 1649, pgs. 56 y 57.

(1) Pocos son los autores modernos que han analizado el concepto de huaca, $y$ estos lo han hecho ligeramente y como de paso; citaremos sin embargo algunos, y en primer lugar, Bandelier, The Islands of Titicaca and Koati, New York, 1910, pg. 100.

Este autor habla de las Achachilas de los indios del lago Titicaca, que son las huacas del antiguo Perú, y las compara con los Shiuana y Kopish - tai de los Queres y los Ojua 
la conquista española, eran diferentes de aquellas en que vivían los Melanesios, los indios de la América del Norto y otros pueblos, de que ya homos hablado; perteneciendo, quizás, el concepto de huaca a un estado de evolución más adelantado, y cercano a la comprensión de la divinidad, como una naturaleza sobrenatural y propia de dioses personales y poderosos, tal como la que se encuentra, desde las albores de la historia, en Grecia (1) \& Asiria (2).

De muchas de las huacas creían que, antes de ser montes, peñascos o islas, habían sido hombres, y que su metamorfosis se había verificado en un período mitológico, que llamaban

de los Tehuas de Nuevo México Achachila es roz aymara emparentada con Achachi, abuelo o progenitor. (Bertonio, Vocabulario Aymara, Leipzig, 1879. Parte II, pg. 5).

Debe también consultarse Payne, History of the New World called America. Oxford, 1892, Vol. I, pgs. 410 y 411, y Reville, The Native Religion of Mexico an Peru, (Hibbert lectures 1884), New York, 1884, pgs. 166 y 167.

En las historias generales del Perú y libros que especialmente tratan de los Incas, publicados en el pasado siglo, apenas si se encuentra algún dato interesante acerca del significado de la voz huaca, pues casi todos los autores se ocupan exclusivamente de los cultos superiores de la religión peruana.

(1) Farnell, Cults of the Greek States. Oxford. 1896, Vol. I, pg. 4. 1898.

(2) Jastrow, Religion of Babilonia and Asiria, Boston, 
purumpacha, (tiempo silvestre) (1), durante la lucha entre los dioses supremos, ya fueron éstos Viracocha, Vichama, Con o Pachacámac, fábulas de las que nos ocuparemos en su debido lugar. Contaban, también, que estas huacas, mientras vivieron, fueron las introductoras del cultivo de los cereales $\boldsymbol{y}$ otras obras de civilización (2).

(1) Purun = silrestre, ordinario, vulgar, general

Pacha $=$ el tiempo, el día. Middendorf, Op. cit., pgs. 674 y 643 .

(2) Volvió (Vichama) el'enojo contra los de Vegueta, i culpandoles de complices.... pidió al Sol su padre los convirtiese en piedras, conversión que luego se izo.... No uvo bien ejecutado el castigo el Sol y el Vichama, quando se arrepintieron de la impiedad.... El Sol y el Vichama no pudiendo desazer el castigo, quisieron satisfacer el agravio, i determinaron dar onra de divinidad a los Curacas i Caciques a los nobles y a los valerosos, llevandolos a las costas y playas....i a otros puso dentro del mar que son los peñoles.... a quien les dicen titulos de deidad.... Calancha, Chronica Moralizada, T. I, Barcelona, 1638, pgs. 413.

Demas desto. Vuestros Sabios dizen, que estas Huacas antes que fueran piedras, y se conuirtieran en Huacas, eran bombres como nosotros de carne, y huessos, y que el Continiracocha, como dizen los Llacuaces, o el Huichama, como dizen los Iuncas, los conuirtieron en piedras. Agora te pregunto. Quien hizo a estas Huacas Dios? Porque vuestros sabios dizen, que antiquisimamente en el Purumpacha eran hombres, $y$ agora vemos con nuestros ojos, que son piedras, o cerros, o peoascus, o Islas en la mar. Dime hijo, quien hizo aquestas Huacas Dioses? De donde les vino la diuinidad. Porque si antiguamente eran hombres, no podian ellas hazerse Dioses asi 


\section{Los indios Thompson y otras tribus Sa- lish dicen que la mayor parte de las rocas de forma singular, fueron hombres o animales,}

mismas. Otro las hizo a ellas Dioses, y siendo assi claro está que quien las hizo a ellas Dioses es mas poderoso que ellas, y mas excelente, y mas sabio, esse será Dios, y no la Huaca, porque si la Huaca es hechura suya, ya no será Dios; porque Dios verdadero no puede ser hechura de otro, porque Dios es el hazedor de todas las cosas, y siendo el hazedor, no puede ser su hechura. Demas desto. Si estas Huacas antiguamente eran hombres, y tenian padre, y madre, como nosotros, y despues el Contiuiracocha los conuirtió en piedras, luego agora son de menos estimacion que antes; porque quando eran hombres (como talsamente dizen vuestros hechizeros) tenian entendimiento y hablauan, y tenian ojos, y pies, y manos, como los demas hombres, pero agora quien las ha de estimar? Quien ha de hazer caso dellas? No veis como las zorras, y los pajaros se ensucian en ellas? Esto puede ser Dios verdadero? Esto puede ser criador? No tienen verguenca vuestros hechizeros, de aner adorado vna piedra sucia de pajaros, y de animales? Dezidme, quando estas Huacas eran hombres como nosotros, antes que fueran Huacas, no comian mayz? No comian papas? No comian charque? Sí. Dime quien les daua entonces este mayz que comian, y las papas, y las onejas? El Dios verdadero, que ellos no conocian, se lo daua todo, como tambien dá de comer a los pajaros, y a los animales, que no conocen a Dios, luego antes que vuiera Huacas, a quien vuestros hechizeros piden el mayz, y las papas, Dios todo poderoso criaua el mayz, y las papas, y crió a essos mismos hombres, que vuestros hechizeros falsamente dizen, que se conuirtieron en Huacas.

Direisme, Padre, estas Huacas, 'quando eran hombres hallaron estas comidas, y ellos las sembraron, y las escardaron, y enseñaron a sus hijos, como las auian de sembrar. Puede ser que sea rerdad. Pero dezidme hijos? quien es mas digno de ser adorado, quien halló estas comidas, o quien las críb, 
en un período mitológico muy parecido al que los Peruanos llamaban purumpacha (1).

Las historias de transformaciones de hombres en animales $u$ objetos inanimados, se encuentran en todas las mitologías, desdo la de la Grecia hasta las de las tribus salvajes de Australia, y ocupan preeminente lugar en las más perfectas obras de arte (2). Y si algunas de estas fábulas han podido tener origen en la semejanza que presentan ciertas pieảras con la figura humana (3), las más son debidas a que, paulatinamente, merced al desarroilo de la cultura, el animismo cede su lugar en las religiones al antropomorfismo; $y$ así, la piedra que era adorada como tal, se convierte en un dios petrificado, $y$ más tarde, en su imagen.

para que los hombres las hallasen? No está claro, que es más digno de ser adorado, quien las crió de nada, para sustentar a los hombres? Dios todopoderoso las crió, $y$ por esso solo Dios ha de ser adorado, y seruido. Avendaño, Sermones en Quichua y Castellauo, Lima, 1649, Tom. I, fls. 42 a 44.

(1) Teit, The Thomson indians. Jesup North Pacific Expedition, Vol. I, New York, 1889 a 90, pg. 337.

(2) Lang, Mythes Culthes et Religions, Traduction francaise par Marilher, París, 1896, pgs. 115 a 149.

(3) Dorman, Primitire superstition, Philadelphia 1881, pgs. 130 a 135 . 
La fuente, tenida por viva y adorada por tal, al andar de los años, no es sino el lugar donde mora la ninfa, bien distinta ya de la corriente de agua en que se baña $y$ cerca de la cual elévase, algunas veces, su templo (1).

(1) Reinach, Cultes Mythes et Religions, París, 1906 y 1908, Tomo I, pg. 42, Tomo II, pgs. 32 y 77. 
$$
\text { , }
$$ 


\section{CAPITULO II}

\section{LOS CONOPAS}

Además de las huacas, que cran reverenciadas por toda una tribu, provincia o clan y que recibían culto público y general, había en el Imperio de los Incas otro género de objetos sagrados, llamados de diferentes maneras, en las varias regiones del Perú y conocidos por los estudiosos bajo la designación de conopas, como los llamaron los antiguos escritores españoles, siguiendo en esto a los indios de los llanos; pues en la sierra recibían el apelativo de chancas o de cunchur, y que han sido repetidas veces comparados a los dioses Lares $y$ Penates de los antiguos romanos (1).

(1) Los Conopas qe en el Cuzco y por alla arriba llaman Chancas son propiamente sus dioses Lares y Penates. Arriaga, Extirpación de la idolatria, Lima, 1621, pg. 14.

Avila, Relación etc. Este documento lo publicamos entre los que acompañan este estudio.

También adoran y reverencian las Conopas que en el Cuzco llaman Chancas y son sus Dioses lares y Penates. Oliva, Historia del Perú, Lima, 1885, pg. 134. 
Estos pequeños objetos ocupaban importantísimo lugar en la rida de los antiguos peruanos; a ellos pedían consejo $y$ de ellos esperaban socorro en sus necesidades. Sólo de un modo particular $y$ secreto los rererenciaban $y$, en los sacrificios que les ofrecían, hacía ordinariamente de ministro aquel que los imploraba; pues sólo rara rez llamaban con tal objeto a los hechiceros (1).

En quichua llamábanles también huresica. mayoc (2), nombre que expresa muy bien su naturaleza doméstica 5 privada, ya que quiere decir el cuidador de la casa (3).

(1) A todos los Conopas, de qualquiera manera que sean se les da la misma adoración que a las Huacas, solo que la de estas es publica y comun de toda la Provincia, de todo el pueblo, o de todo el Ayllo, segun es la Huaca, y la de los Conopas es secreta, $y$ particular de los de cada casa. Este culto y reneración o se la dan ellos mismos por sus personas.... o (rara vez llaman al Hechizero. Arriaga, id. id., pg. 15.

(2) Huasi=la casa, la habitación, la sala; la torre; la cuera de los animales, el nido de los insectos; la familia, los inquilinos. Huasi - camayoj = el mayordomo, Middendorf, Wörterbuch des Runa Simi oder Keshua Sprache, Leipzig, 1890, pg. 442 .

(3) $Y$ assi los llaman tambien Huasicamayoc el mayordomo o duefo de casa. Arriaga, extirpación de la Idolatría, Lima, 1621. pg. 14.

Assi los llaman Huacicamayoc que es el mayordomo o dueto de la casa, Olica, Locu cit. 
Había conopas de dirersas materias y figuras, si bien ordinariamente eran piedrecillas pequeñas, desprovistas de todo trabajo, y que tenían alguna particularidad, en su forma o en su color (1), sin que faltaran ótras cuidadosamente labradas, imitando objetos naturales.

Los cálculos o piedras bezares (2) que tan misteriosos e inexplicables debían ser para los antiguos indios, cuya atención no podía menos

(1) Avila, Relación de la Idolatría de los Indios de este Arzobispado de los Reyes.

Son de diversas materias y figus (sic) ordinario son algunas piedras particulares y pequeñas que tangan algo ras (sic) annq ${ }^{\circ}$ de notable o en el color o en la figura. Arriaga, id. id., pg. 14. Esta frase como muchas otras de Arriaga se hallan textualmente copiadas, salvo los errores de imprenta, en Villagómez, Carta Pastoral de exhortación e instrucción contra la idolatría de los indios del Arzobispado de Lima, Lima, 1649, fol. 39 v.

Estos ydolos suelen ser de diversas materias y figuras, pero de ordinario son de algunas piedras particulares y pequenas, que tengan algo de singular o notable en el color o fijura. Oliva, Loco cit.

(2) No solamente los barbaros americanos, quienes confiaban en la virtud $y$ eficacia de la piedra bezar, sino tambien los civilizados de Europa y el Cesar Carlos V. tomo piedra bezar para librarse de tristeza y melancolía, y como de un contraveneno poderoso le administraban los médicos del renacimiento, siguiendo a los arabes. Téase el curioso tratado "De la piedra Bezaar y la Yerua Escuerçoneras en Monardez, Primera segunda y terceras partes de la Historia Medicinal de las eosas que traen de nuestras Indias Occidentales, Sevilla, 1574. 


\section{Religión del IMPERIO de los INOAS}

de tijarse en piedras encontradas en tan sinsulares circunstancias, eran conopas mu apreciados, especialmente para obtener la multiplicación do los ganados. Su nombre ora el de Illa o Quicu (1).

Los llevaban en sus mochilas *considerándolos como talismanes, cura presencia los protege contra enfermedides 5 desgracias * (2). Tan poderosos los consideraban para atraer la buena rentura, que las roces illayog e illasapa corresponden a renturoso e hijo de la dicha; $r$, en tiempos indudablemente poshispánicos, las monedas antiguas, que las indias lleran suspendidas del cuello $r$ que creen son un eficaz amuleto para obtener riquezas, han recibido el nombre de illa-kolea (3).

Los costeños tenian también por conopas

1 Por cozopas szelen teper algunas piedras bezares que los Inaios thamahs= Quicu. Arriaga, id. 1d.. Pg. 15.

Se diezez por cosopas las piedras bezares que llaman Illa o si iss az ajcrabo o sicraz. Tillogúmez. Op. cit. tol. I Oli. Ta, \$E. IBj. Otza citada.

2 Midiendorf. Torterbuch des Ruza Simi order keshus Spracie, Leipzig. 1840. FE. 35.

s İ. id.. Ig. sob.-Sotre el origen de las piedras beza-

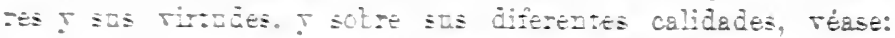
Herren. Historis gezerel de los Ëcchos de los Castellanos en las Isias Tierra Fime ael Mar Ocreno. Decada Quinta, Madrid $1728.985 .95 \mathrm{y} 90$ 
a unos cristales pequeños, que llamaban lacas (1).

Acudían a los conopas los antiguos indios en sus enfermedades o en cualquier otro trabajo que les sobrerenía (2). Las mujeres, especialmente, esperaban que las socorriesen en el parto; para lo cual ofrecían sacrificios a aquo. llos que les eran propios, llamando para esto a los hechiceros o sacerdotes, quienes se los colocaban encima de los pechos, creyendo, de este modo, facilitar el desembarazo (3).

Además de estos conopas, que podemos llamar generales, había ótros, cuya esfera de influencia era más reducida y estaban cspecializados para diversos fines; así, había conopas para el maíz (zara - conopas, arihua - zara, huantai-zara, zara-mamas), las patatas (papa-conopas, acsu-conopa (4), y las llamas (llama-

(1) En los llanos tenain muchos por Conopas vnas piedras pequeñas de cristal al modo de puntas y esquinadas que llaman Lacas. Arriaga, Op. cit., pg. 15.

(2) Avila, Relación de las Idolatrías etc.

(3) Quando la inuger esta de parto, suelen llamar a los Hechizeros, para que ha sacrificio al Conopa, que tiene como propia suya la muger y se la ponga encima de los pechos; y la traiga sobre ello para que tenga buen parto. Arriaga, Extirpación de la Idolatría, Lima, 1621, pg. 32.

(4) Agsu, Dep. de Junin, especio de papa. Middendorf, Op. cit., pg. 20. 
conopa, illa llama, caullama). Atribuíanles poder para aumentar sus ganados o para hacer fructificar abundantemente sus sembríos. A menudo, los zara-conopas eran preciosas mazorquillas de maíz, trabajadas en piedra con esmero. Estos objetos no son raros en las colecciones de antigüedades peruanas, así como ótros, en forma de llamas, que eran los conopas a cuyo cargo estaba el aumento de estos animales, y cuyo uso subsiste aún hoy, como lo ha demostrado Max Uhle. Parece que los llama - conopas eran, en muchas ocasiones, illas o piedras bezares (1).

(1) Ay tambien Conopas mas particulares, rnas para el mayz, que llaman Zarap conopa, otras para los papas Papap conopa, otras para el aumento del ganado que llaman Caullama, que algunas vezes son de figura de Carneros. pg. 15.

Otras (zaramamas) son de piedra labradas como choclos, o mazorcas de maíz con sus granos relevados, y de estas suelen tener muchas en lugar de Conopas. Pg. 16, Arriaga, Extirpación de la Idolatría, Lima, 1621.

No me he olvidado hijos de vuestros Conupas, muy bien se, que teniais en vuestras casas las Conupas, rnas para el mayz, y las llamauais carap - conupã, y Huan - tay zara, y Arihuacara, otras para las papas, $y$ las llamauais papa conupa, Acsu conupa. No era asi. No lo podeis negar; porque los Visitadores, os las quitaron, $\mathrm{y}$ las quemaron; $\mathrm{y}$ tambien teniais Conupas para el ganado, que las llamauais Llamap conupa, y vuestros hechizeros os dezian que estas Conupas tenian poder para dar buen mayz, y para el aumento de ruestros ganados, 
Transmitíanse, ordinariamente, los conopas de padres a hijos, siendo el mayor o principal aquel que los heredaba (1), reverenciándolos todos los descendientes de su primitivo posesor. A falta de herederos consanguíneos, encomendaban su custodia al pariente por afinidad, que les parecía más cercano, o a la persona con quien tenían mayor amistad, $u$ optaban por llevarlos a la tumba del proge-

y de ruestras chacras. Avendaño, Sermones en Quichua y Castellano, Lima, 1699, fol. 54 (?).

$\mathrm{Si}$ an tenido, o tienen en sus casas, ó en otras partes, Conopa, Zaramamas, para aumento del ganado, pg. 56 a 59. Que Conopa, o Chanca tiene? (que es un Dios penate? y si es Ascuy, Conopa, ó Zarapconopa, ó Llamaconopa? si es Conopa del maiz, ó del ganado, pg. 61 a 63 . Villagomez, Carta Pastoral de Exhortación contra las idolatrías del Arzobispado de Lima, Lima, 1699.

Sobre los illas, como Llama-conopas, véase la «Relación de la religión y ritos de los indios de Guamacucho (Colección de inéditos, relativos a la conquista y colonización de América y Oceania, Tomo III, pg. 50.

Uhle Max, Las llamitas de piedra del Cuzco. Rerista del Instituto Histórico del Perú, Vol. I, Lima, 1806.

(1) Pero lo ordinario es, que las conopas se hereden siempre de padres a hijos, $\mathrm{y}$ es cosa cierta y averiguada en todos los pueblos que entre los hermanos, el mayor tiene siempre la Conopa de sus Padres. Arriaga, Extirpación de la Idolatría, Lima, 1621, pg. 15.

Herédanse estas Conopas de padres a hijos y estan siempre en el mayorasgo de la casa como vínculo principal della, Olira, Historia del Perú, pg. 135 
nitor y depositarlos allí; y, cuando nada de esto era posible, enterrábanlos en la casa (1).

Mas no todos los conopas tenían igual historia; pues acontecía que, topándose un indio con alguna piedra o con cualquiera otra cosa, bajo algún concepto notable, la recogía e iba a un hechicero y preguntábale el significado de su hallazgo; a lo cual éste contestaba, diciéndole, con admiración, «éste es conopa reverenciale $y$ mochale con gran cuidado que tendras mucha comida $y$ gran tranquilidad».

Para resolver si esta clase de objetos eran conopas, servíanse, en otras ocasiones, de piedrecillas, con las que echaban suertes como con dados (2), sistema de adivinación muy empleado en el Perú.

(1) Avila, Relación de la Idolatría de los indios de este Arçobispado de los Reyes

(2) $Y$ acontece algunas veces (y no son pocas las que se han topado de estas) que cuando algun Indio o India se halló alguna piedra de esta suerte, o cosa semejante en que reparo va al Hechizero, $y$ le dize Padre mio, esto he hallado que sera? y él le dize con grande admiracion, esta es Conopa, reverenciala, y mochala con gran cuidado, que tendras mucha comida y grande descanso. - Otras vezes con vna pedrezuela larguilla y esquinada, que sirve como de dado para hechar suertes la hecha y saliendo buena dice que es Conopa. Arriaga, Op. cit., pg. 15. Véase Villagómez, Carta Pastoral de exhortación e instrucción contra la idolatria, Lima, 1649 folio 39 v. 
Homos dicho anteriormente que en la Sierra llamaban a los conopas, cunchur y chanca; mas estas dos palabras no eran equivalentes, pues si ambas significaban objetos de igual género, se aplicaban a piedras, cnyo papel, en los ritos domésticos con que imploraban su auxilio, era diverso. Así, el modo de servirse de ellos era el siguiente:

Sacaban al cunchur y al chanca, que comúnmente eran piedras rústicas, que guardaban envueltas en trapos 5 , con ellos, un paco do coca y unos ataditos de cuero, que contenían polvos amarillos, paria o cinabrio pulverizado, mulla, o sea conchas marinas molidas (1), oropel $y$, en algunas ocasiones, un pedacillo de

Por que en algunas ocasiones con una pedresuela larguilla y esquinada que sirue como de dado para echar suertes la echa el hechicero y saliendo buena le dice al yndio que es conopa y con esta aprobación y canonización tiene ya su Dios Penate y para que nos apiademos destos pobres y miserables naturales y echemos de ver quan grande es su ignorancia y ceguedad a acontecido hallarse en poder de una yndia un pedaço de lacre y en otra una bellota de seda de las que se suelen poner en las capillas de las capas aguaderas y en poder de otra un nudo de vidrio del pie de una talla y lodas ellas adoran $y$ veneran como Conopas y Dioses Penates.

(1) $\mathrm{Si}$ con ellas (las conopas) tíenen mullu pariasto o otras ofrendas que les hacen. Villagómez, Carta Pastorial de exhortación contra la idolatria de los Indios del Arzobispado de Lima, Lima, 1649. fol. 56 a 59. 
plata. Tomaban luégo dos o tres piedras planas, del tamaño de una mano, y en ellas disponían los dichos polvos, formando líneas, y con el pedacillo de plata las raspaban hasta dejar señal. Oolocaban juntamente unos conejillos de Indias, vasos (mates) de chicha ordinaria $y$ un poco de aquella que llamaban tecti yapaichi (1), que era como mazamorra espesa, hecha de maíz, mascado por muchachas vírgenes o, a falta de éstas, por mujeres que durante su fabricación, guardaban castidad y se abstenían de comer sal $y$ ají (2). Para esto habían previamente dispuesto al cunchur y al chanca sobre un poco de paja limpia. Entonces dirigíanse al cunchur, implorándole su anxilio como a padro $y$ pidiéndole les manifestase cnál era la huaca que, con su enojo, causábales el mal que sufríau; $y$, lanzando el chanca (3) al aire, preguntaba si el enojado era el Sol, $y$ del modo como caía, deducían la respuesta, y siendo afir-

(1) Tejti = Chicha cocinada con mani, a la superficie de la cual nadan gotitas de aceite. Middendorf, Wörterbuch des Runa - simi oder der keshua-Sprache, Leipzig, 1890. 1621.

(2) Arriaga, Extirpación de la idolatría, pg. 24, Lima,

(3) Chancay $=$ tirar algo alzando la mano. Middendorf, Op. cit., pg. 343 . 
mativa, repetían la experiencia, $\mathbf{y}$, en cayendo el chanca por un lado diferente que la primera vez, quedaban por ciertos de que era el Sol que los castigaba, y trataban de aplacarlo por medio de sacrificios. Si las cosas sucedían de otro modo, continuaban echando suertes y preguntando si tal o cual huaca estaba irritada, hasta obtener una respuesta definitiva. Obtenida ésta, el que hacía de oficiante, dirigiéndose al cunchur y pidiéndole su intercesión, soplaba los polvos que habían colosado en una de las piedras planas, de que antes hablamos; tras lo que regaban un poco de coca y tecti. Sacrificaban luégo un cuy, cuyas entrañas examinaban, hinchando de aire los pulmones y, según la forma que tomaban, deducían si el sacrificio había sido o no aceptado; continuando el sacrificio hasta estar ciertos de que había sido grato a las huacas. Hecho esto, ofrendaban nuevamente al dios enojado, los polvos que habían puesto en las otras piedras, vertían la chicha y el resto del tecti en el suelo y mataban unos cuantos conejillos de Indias más (1).

(1) Franco de Avila, Relación de la idolatría de los Indios de este Arzobispado de los Reyes que se ha descubierto y diversidad de idolos que adoran. 
Quien haya leído con atención las páginas anteriores, en las cuales hemos resumido fielmente lo que los escritores castellanos de los siglos XVI y XVII han dicho de los conopas, habrá podido notar cuán exacta aplicación encuentran en este asunto, las ideas que hemos desarrollo en el capítulo antecedente.

La primitiva concepción de mana, wakonda etc., que hemos creído encontrar en la idea de huaca, se manifiesta claramente en la de conopa.

En efecto, si no acudimos a ella, encontraremos inexplicable y absurdo el modo cómo los antiguos moradores del Imperio de los Incas obtenían nuevos conopas, y muchas de las otras particularidades que acabamos de exponer.

Mas, no por derivar de una misma concepción de la fuerza misteriosa y sagrada, la creencia en las huacas y en los conopas, la diferencia que existe entre estas los clases de objetos sagrados es más pequeña, que, a nuestro, juicio, Estas eran más distintas entre sí, de lo que, a primera, vista, parece, y de lo que los cronistas nos dan a entender.

Las huacas correspondían, en las rudimentarias concepciones de los antiguos peruanos, 
a los dioses de otrus pueblos de más desarrolladas ideas religiosas; $y$ los conopas eran amuletos. Esta es la opinión de Lowie (1), al estadiar los amuletos americanos, $y$ esperamos que será la del lector, después de habernos seguido en el brebe examen, que, de algunos de los talismanes de que se sirven otros pueblos de América, ramos a hacer en las páginas siguientes.

Generalmente, se entiende por amuleto un objeto portátil que se lleva sobre la persona o se guarda de otra manera, al cual se atribuye poder mágico religioso para alejar un daño u obtener un bien.

Los objetos que han servido como amuletos son muy varios, tales como piedras, o vegetales de forma singular, partes de animales o reliquias de muertos.

Muchos amuletos derivan su virtud de una semejanza más o menos real con el objeto, sobre el cual se les atribuye influencia.

Los objetos adivinatorios, guardados dnrante largo tiempo $\boldsymbol{y}$ empleados a menudo,

(1) Lowie, Charms and amulets in America of Hastings Encyclopaedia of Ethics and Religion, Edinbourgh, 1911, Tomo III, pg. 408. 


\section{ReLIGión DeL IMPERIO DE LOS INCAS}

llegan a convertirse en amuletos, dotados de virtud para producir los hechos que predicen.

Los fines para que sirven los amuletos son: $\mathbf{1}^{0}$. curar o evitar ciertas enfermedades; $2^{0}$. librar de determinados peligros; $3^{0}$. dar buena suerte o vigor; $4^{0}$. la realización de determinados deseos, tales como éxito en el juego, aumento de riqueza, fructificación de ganados y sembríos, triunfos de amor, fertilidad etc.

I ${ }^{\circ}$ amuletos están fundados en el concepto de una fuerza mística y mágica, tal como mana (1).

No siempre es fácil decir si una cosa es un amnleto o un fetiche, puesto que, bajo algunos respectos, ambas clases de objetos tienen gran semejanza y casi igualdad. Así, no debe sorprendenos que Spencer haya clasificado entre estos últimos los conopas del Perí (2), ya que fotiche es un objeto material, morada perpetua o momentánea de un dios o de un espíritu natural, o del de un muerto o un instrumento para obtener, de un modo sobrenatural, fines no acequibles de otra manera.

1) Barbara Freire- Marreco, Charms and amulets. Has. tings, Op. cit., pg. 393 a 398.

(2) Lewis Spence, Fetichism in America Hastings, Op. cit., Edimbourgh, 1912, vol. V, pg. 903. 
Machos fetiches están poseídos por espíritus indeterminados (1).

Previas las antecedentcs nociones generales, daremos, pues, principio a unestra ligera revista de los talismanes americanos, no sin adrertir antes que, estando mucho mejor estadiada la etnografía de la parte setentrional del Continente, nuestros datos, relatiros a la América del Sur, serán mucho más deficientes que los que podamos exponer acerca de las tribus que moraban al Norte dol Istmo de Panamá.

Pocos pueblos americanos son conocidos, - bajo el respecto que ahora nos interesa, mejor que los esquimales; pues el aislamiento $y$ difíciles condiciones en que riren, han sido poderosos incenticos de la curiosidad de los etnólogos, que, sin retroceder ante las más duras penalidades, han estudiado, con detención, esto pueblo singularísimo.

Lns esquimales de Groenlandia tienen amuletos muy numerosos, que llaman comuaq de quienes creen ohtener iterminadas cualidades y que dicen les libran de ciertos peligros o males 5 aun de la muerte, ejerciendo su pro-

(1) Aston, Fetichism in Hasting, Op. cit., Fol. V, pgs. 884 จ 896. 
tección, sobre todo, en los niños, que siempre andan cargados de talismanes.

Son estas piedras que tienen alguna sin. gularidad, huesos u otros restos de animales o ares, $y$ los llevan de ordinario colgados del cuello.

La mayor parte de estos amuletos están fundados en principios de magia por contacto, sin que falten ótros, cuya psicología sea de más dificil explicación. Los padres hacen que sus hijos lleven cabezas, garras u otras reliquas de halcones, para que sean buenos cazadores, $y$ un pedazo del vestido de un europeo, para darles la habilidad e inteligencia de la raza blanca.

En los botes ponen cabezas de zorlos $y$ en los arpones, el pico de una ágnila (1).

Los cazadores que moran en la Bahía de Hudson, para capturar cierros $\$$ obligar a estos animales a correr en determinada dirección, fabrican un muñeco, a imagen de algún cazador famoso, y cuélganlo de un palo, en un lugar a propósito.

Los talismanes de estas gentes están destinados a guardar a su dueño de los ataques

(1) Crantz, History of Greenland, London, 1767, Vol. I, pgs. 216 y sigts. 
de los malos espíritus, siendo algunos representaciones de parientes difuntos.

Muchos de los nombres personales, de que se sirven, designan objetos naturales. Los quo tales nombres usan, llevan ana imagen o una porción de la cosa de que se deriva su apelativo.

Frecuente es el empleo de las ropas de un muerto, para obtener el auxilio de su espíritu, así como el de restos de animales, cresendo, de este modo adquirir sus propiedades.

Los objetos extraños y nunca ristos juzgan que dan buena ventura a quien los halló.

Un talismán curioso de estas gentes era el que representaba cuatro cabezas de hechiceros célebres (1).

Según Boas, en las ideas religiosas de los esquimales del Centro, los tornait o señores invisibles de todas las cosas son los scres más poderosos después de Sedna.

Todos los objetos tienen su dueño invisible o inua que puede convertirse en el genio de un hombre, que entonces adquiere las cualidades de angakunirno o hechicero, lo cual

(1) Turner, Etnology of the Ungava Districit Hudson Bay Territory $11^{\text {th }}$ Annual Report of the Bureau of Ethonologie, Washington 18:4, pg. 201. 


\section{Religión deL Imperio de LOS INOAs}

acontece más fácilmente con los inuas de los osos, o de las piedras o con los hummnos.

El tornait de las piedras vive en las grandes rocas, que hay esparcidas por todo el país, las cuales creen que son huecas $y$ proristas de una entrada secreta, sólo conocida de los heehiceros.

Estos esquimales no fabrican imágenes de los tornait; pero se sirren mucho de amuletos arnigoas, los cuales, si bien algúnos son dados por un tornait, son la mayor parte hereditarios. Los amuletos más comunes son plumas de lechuzas, dientes de osos u otras cosas semejantes; aví como minerales raros, que envuelven en un pedazo de piel. Un retazo de la primera vestidura de un niño es tenido por poderoso talismán.

Llevan sus amuletos en medio de la espalda, en la chaqueta interior (1).

Los esquimales del Cabo Barrow dan mucha importancia a los amuletos que lleran en sus personas, en sus botes $y$ aun en algunas armas. Estos son de virias clases; los hay hochos de pieles, huesos $u$ otros restos de ani-

(1) Boas ('T.), The Central Eskimo 6 th $^{\text {th }}$ Annual Report of the Bureau of Ftnology. 1884-85, Washington, 1888, pg. 591 a 592 . 
males, con los cuales creen obtener las cualidades de éstos; ótros son hechos de plumas, como los que con las del águila dorada hacen y que llevan en sus botes; ótros son objetos que, por su forma, recuerdan el efecto que con ellos se quiere obtener; de éstos, únos son naturales ótros artificiales, tales como los en de forma de lobo marino, hechos de piedra estallada.

En fin, cada clase de amuletos parece estar destinada a distinto fin $y$ ser éstos más apreciados, cuando han pertenecido o estado en contacto con sujetos respetados, tales como los antepasados, o los cazadores famosos (1); y parece que, en general, tolas estas gentes consideran dotados de virtudes sobrenaturales y estiman en mucho todos aquellos objetos que han permanecido largos años en poder de la familia (2).

Entre los que moran en la costa de Norton Sound y en el bajo Yukon, además los de dientes, colas y orejas de lobo $\mathrm{n}$ otros anima-

(1) Murdoch (John), Etnological Results of the Ponit Baraw expedition $9^{\text {th }}$ Annual report of the Bureau of Ethnologic 1887 - 88, Washington, 1892, pg. 430 a 441.

(2) Lewis Spence, Fetichism in America Hasting, Op. cit., Vol. V, pg. 899. 


\section{Religión del IMPerio de los InOAS}

les semejantes, y de las pieles de armiño, tenían por talismán muy poderoso para la caza, el cuerpo seco de un niño pequeño, que, en un saco, llevan sobre sí o en sus canoas. Para que esta momia tenga virtud, era preciso que, el recién nacido, haya sido asesinado en secreto y su cuerpo robado, sin que nadie se enteraso de lo ocurrido. Con el mismo fin, emplean máscaras o figurillas de animales, más o menos reales, pequeñas piedras $\boldsymbol{y}$ cristales.

Agujereábanse las narices para colocar amuletos, hechos de concha (1).

Los Iniuts llevan como amuletos, dientes y figuras de animales (2).

Los esquimales del Estrecho de Bering se sirren de amuletos do madera, piedra y hueso. A menudo, la virtud es inherente al objeto; a veces, comunicada por el encantamiento de un hechicero. Un objeto doméstico, por su antigiiedad y larga posesión en la familia, es tenido por talismán, guardado como valioso tesoro y trasmitido de padres a hijos. Esperan

(1) Spence, Op. cit., in Hastings Encyclopaedia, Vol. V, pg. 899.

Dorman, The origin of primitive supersticions, Philadelphia, 1881. pg. 158.

(2) Dorman, Op. cit., pg. 158. 
protejan y ayuden al que les posee, merced al poder sobrenatural e inteligencia de que los creen dotados.

Esperan qne los amuletos les libren de ciertos males, especialmente físicos y les den éxito en las cacerías.

Las mujeres llevan collares de cascabeles, hechos de molares de reno, arrancados con un pedazo del alvéolo; a estos atribuyen singulares virtudes.

Cuando una mujer no tiene pronto hijos, para conjurar la esterilidad, el brajo practica ciertas ceremonias secretas sobre un muñeco, con el cual duerme la mujer.

Para tener suerte en la caza, además de la momia de un recién nacido y de máscaras, sírvense, como otros hiperbóreos, de representaciones de animales, más o menos, míticos. A estos talismanes creen dotados de ana clarividencia sobrenatural para ver las presas a una gran distancia, merced a lo que guían al cazador y lo conducen al lugar propicio; dicen otros que los amuletos atraen a los animales (1).

11) Nélson, The Eskimo of Bering Strait 18 Annual Report of the Bureau of Ethnologie, 1896 a 97, Washington, 1899, pg. $427-41$. 
Sírrense también, con igual fin, de momias de animales; $y$, cuando matan un lobo marino, córtanle pedazos, y estos guardan cuidadosamente $y$ en ellos frotan las puntas do las flechas, para que éstas hieran eficazmente (1).

Antes de seguir adelante? a riesgo de salirnos del programa que nos habíamos trazado, no podemos resistir al deseo de exponer a la consideración del lector algunos datos sobre los talismanes de ciertas parcialidades, moradoras del extremo oriental de Siberia, pues pensamos que scrrirán para ilustrar la psicología de las razas primitivas $y$ proyectar mucha luz en el asunto que dilucidamos, $y$ para esclarecer la verdadera naturaleza de los conopas.

Los Koryak además de los dioses espiri. tuales que son comunes a toda la nación, tienen guardianes o protectores propios de cada tribu, familia o individuo, $y$ aun, en ciertas raras ocasiones, de todo un pueblo. De estos guardianes esperan que evitarán todo mal a sus dneños y les proporcionarán ciertos bienes particulares. Unos son generales, ótros sólo tienen poder para fines determinados.

1) Dorman, Op. cit., pg. 157. 
Los atensilios empleados para producir faego por fricción, esto es, una planchita, en forma humana, muy tosca, con algunos huecos, y los palos con que la frotan son los guardianes de los rebaños y los tutelares del hogar, tanto entre los Korigak, que viven en la ribera, del mar, como entre los que se dedican a la cría del reno, y moran en el interior del país.

En el lado izquierdo de las casas $y$ junto a la puerta que llera al pórtico, tienen estas gentes un sitio exclusiramente destinado para guardar sus amuletos. Allí colocan la planchita, con que producen el fuego, en lngar eminente, poniéudole algunos adornos. Cuand, está ya demasiado usada, hacen una nueva que ocupa el lugar de la antigua; mas conservan también ésta, con cuidado, entre los objetos sagrados.

El tambor es el señor del dormitorio. Toda pareja de casados tiene su tambor. $Y$ así como no puede haber rebaño sin un fuego sagrado, así no puede haber familia siu tambor.

A otros espíritus guardianes lliman ketnaks y kalaks, y algunos do éstos comunes a toda una población, son un poste rudamente tallado. 
Hay amuletos para las redes, muñequitos muy rudamente trabajados; ótros hay, que lleran consigo cuando viajan, y son como rosarios de diminutas figurillas humanas, atadas a una cuerda; ótres, en fin, son protectores especiales de los niños.

Los botes, hechos de pieles, tienen un carácter sagrado y no deben servir sino a una sola familia. En ellos hay una figurilla humana $y$ un haz de palillos, que son talismanes.

Antropomorfo es el que suspenden en la tienda de dormir, este protege a las mujeres e impide que sean estériles. Igual forma tienen los que farorecen a los cazadores; y atriruyen idéntica virtud, su figurilla es de madera talladid en forma do focas.

A reces, una flecha, con la que se ha matado a un lobo, es ofrecida a los espirítus, y guardada con los otros amuletos.

La piedra adirinatoria juega un papel importante en la vida ritual de los koriaks $\boldsymbol{y}$ es uno de los objetos indispensables en el hogar de la familia. Por medio de ella, so adirina, antes de toda acción de algnna importancia, cuando se va a dar nombre a un niño, antes de partir para un viaje, duranto las festividades de las focas etc. etc. 
La piedra adivinatoria consérvanla en una bolsa de cuero, de la cual cuelgan otros amuletos. Para servirse, la colocan sobre uno o varios palos; $\mathbf{y}$, si al sacudirlos, cae, tienen la respuesta por negativa; 5 , si permanece en su lugar, creen que ha contestado afirmatiramente. Estas piedras son guijarros redondeados, tomados en la orilla de los ríos por personas conocedoras o hechiceros, y que, las han consagrado, pronunciando sobre ellas un eneantamiento (1).

En este pueblo, muchos amuletos no son sino piedras a otros objetos naturales, que, por alguna circunstancia, hieren la imaginación de un aborigen. Así, cuenta Krasheninnikoff que un koryak marítimo, que vivía en el pueblo de Uka, en la costa oriental del Norte de Kamchaka $y$ que sufría, desde hacía varios años, de una enfermedad renérea, probablemente sífilis, un día, paseando por los bancos del río A'dka, encontró una piedra que, al tomarla, respiró, echando sobre él un álientí sem(jante al do un hombre. Arrojóla, mas, poco después, agravóse mucho su mal hasta verse obligado a

(1) Jochelson (Waldemar), The Koryak. Religion and Miths. The Jesup North Pacific Expedition, Vol. VI, p. I, New York, 1905 , pgs. 33 a 44 y 74. 


\section{ReLigión DeL J MPERIO DE LOS INOAS}

guardar cama durante todo un invierno $y$ un ve. rano. Al año siguiente, recordando lo ocurrido, fué a buscar la piedra y encontróla juntamente con otra más pequeña; las tomó consigo, las lleró a su casa, donde les hizo restidos; y como, poco tiempo después, sintiese notable ali. rio en su dolencia, tomó a la menor por hijo y a la ótra por mujer, llerando ésta siempre consigo, en sus viajes y expediciones de caza, estimando a ambas como a poderosos amuletos (1).

Muy interesanto es averiguar como entre estas gentes la imagen de un animal o de un hombre, hecha por otro hombre, o un objoto, de natural, desprovisto de toda apariencia de vida, llegan a ser revereuciados como amuletos o espíritus guardianes. A este propósito, nos narra Jochelson un caso típico $\theta$ interesautísimo, por él observado.

Dos bermanos korsaks, pastores de renos, moradores del río Tilpai, a la muerte de su padre resolvieron ririr separadamente y repartirse el rebaño. Siguiendo la costumbre, la planchita, empleada en la producción del

(1) Bogoras (Waldemar), The Chukchee The Jesup North Pacific Expedition, Vol. VII, New York, 1906, pgs. 338 a 348. 
fuego $\Sigma$ que es el protector del ganado, fué dada al hermano menor. Vióse entoices el ótro en la necesidad de fabricarse una nueva; fué a buscar sus hachas y, a pico, regresó con lo que le hacía falta; púsola a secar subre el fuego sagrado del hogar (obteuido por fricción) $y$, de allí a pocos días, procedió a la consagración. Mató un reno, como sacrificio a gicho'-l-eti' noila en $y$ con la grasa $y$ sangre de aquél untó la planchita. Hecho esto, la madre de los dos hermanos recitó sobre ella un encantamiento, en el cual conjuraba al gran cuerro se posase sobre la nuera planchita, para guardar la morada $y$ el rebaño. Hízose entonces, por primera rez fuego, sirriéndose de ella; $f$, cuando salió un humo oscuro, el hermano masor exclamó: "Ahora ya mi rebaño tiene guardián!» (1).

Como mus bien dice el autor, según cṇ̣o testimonio hemos escrito lo antecedente, hay dos elementos que participan de la transformación del pedacillo de madera, rudamente trabajado en forma humana, en amuleto protector de los ganados. El primero, el concepto

(1) Jochelson (Waldemar/, The Koryak Religion and Miths. The Jesup North Pacific Expedition, Vol. VI, pgs. 32 a 34, New York; 1095. 
de fuerza mago-mística inmanento en toda la naturaleza, aun en los objetos inanimados, $\mathbf{y}$ el segundo, la rirtud de encantamiento que, de un modo sobrenatural y misterioso, desarro. lla esta fuerza latente, la encamina y dirige a un fin determinado (1).

Los amuletos de las dos ramas en que se dividen los chukchis $\Sigma$ los de los esquimales que moran en el Oriente de Siberia, son muy semejautes, diferenciándose según las condiciones de vida pecnliares de la famila a que pertenecen. Así, eutre los pastores de renos o moradores de la montaña, los talismanes son para proteger los rebaños, mientras los de los costeños, que viven de animales marítimos, están destinados a proporcionarles abundante pesca y cacería.

Los chukchis como los koryaks tienen amuletos que son simples objeios naturales, desprovistos de tuda labor y que, como dicen ellos, han sido tomados $y$ estimados por talismanes, porque han manifestado, por medio de alguna señal especial, deseo de ser recogidos. Esto opinan, cuando, en su ballazgo, acontece

(1) Op. cit., id. in. 
algo que hiere su atención, como cuando los encuentran bajo la cama etc.

En estos dos pueblos, los talismanes antropomorfós son de una ejecución muy ruda, mientras los juguetes son de un trabajo esmerado $y$, en ocasiones, artístico.

El nombre que los chukchis dan a sus amuletos es inend-u'-lem. Desígnanles además con los calificatiros de asistentes vi'golin, auxiliadores vire'-tilin, compañeros o asistentes viret'-tu'ingin. La misión de éstos es proteger los objetos y personas, con los cuales están unidos. Lléranlos ordinariamente sobre sí y su protección es apetecida especialmente en los viajes por regiones dseconocidas.

Oada aborigen tiene uno o varios de estos guardianes. Estos son: ya rudas imágenes humanas o de animales, hechas de madera; pieles do animales, especialmente las do los armiños; tiras de cuero con nudos.

Ponen también talismanes en los instrumontos, destinados a la caza y a la pesca.

Además de estos talismanes, que podemos llamar individnales, tienen los chukchis ótros, que pertenecen a toda una familia, cuyo bienostas protegen.

Entre los pastores do renos, los objetos 
que sirren para obtener el fuego del hogar, ocupan el lugar preeminente entre todos los objetos sagrados, especialmente la planchita, tallada en forma humana, sobre la cual se produce el frote. Cuando una familia posee varias de éstas, la más antigua es tenida por la protectora del rebaño, y las otras, según su edad, de la caza, de los sacrificios etc.

Las familias tienen también unas esplecies de rosarios, formados de figurillas humanas, atadas a una cuerda (la cual quizás no sirre sino para evitar que estos diminutos objetos se extravíen en los constantes riajes); llámanlos protectores contra la desgracia tai'mikulhin. La mayor parte do estos diminutos talismanes, son figurilias de madera; pero, en algunas cuerdas, se encuentran pedazos de restidos mortuorios o de pieles $y$ esqueletos de animales pequeños.

Gnardan un tambor en el dormitorio, tambor que es respetado como un poderoso amuleto.

Entre los chnkeihs marítimos, los amuletos son casi los mismos; así, tienen los atados on cuerdas, si bien les dan menos importancia.

En lo que se diferencian únos de ótros es en que los amuletes marítimos lienen para la 
caza de animales marinos y que, en su mayor parte, pertenecen al bote. Son éstos la punta de un arpón ya inútil, herramientas gastadas que sirvieron para la fabricación de la canoa, un par do calaveras de Larus argentutus, piedras de echar suertes, pedazos del cuerpo de una foca, que guardan en una bolsa, que haya servido en las ceremonias de las focas, etc., etc.

Algunos de los juguetes con que se entretienen las muchachas son amuletos, para que sean fértiles (1).

Entre los moradores de las islas Alentinas ora universal el uso de amuletos. Ios cazadores tenían gran aprecio a una piedra rara, que llamaban thhimkee. Ningún animal, ni el más feroz, podía resistir a su imán, y el feliz mortal que la poseía no necesitaba fatiga alguna para obtener las mejores presas. Otro poderoso talismán era la grasa de los muertos (2).

Regresando a América, notaremos que, entre los kadiak, al principiar la primavera, los cazadores de focas suben a las montañas en

(1) Bogoras, (Waldemar), The Chukchee. The Jesup Norh Pacific Expedition, Vol. VII, New York, 1906, pgs. 338-35S y 362 a 67.

(2) Bancroft, The Native Races of the Pacific States of North America, London, 1875, Vol. III, pgs, 144 y 45. 
busca de plumas de águilas, de lana de osos, de piedras de formas raras, de raíces singulares, de esqueletos de pájaros y de otras cosas semejantes, que tienen después por amuletos (1).

En las páginas antecedentes hemos tratado de los pueblos borcales que, bajo muchos conceptos, se diferencian de los verdaderos indígenas americanos. Ahora, al comenzar a ocuparnos de éstos, recordaremos que, como ya hemos dicho, en la mayor parte de las naciones de la América Setentrional es costumbre que al llegar un muchacho a la pubertad, trate, por medio de aislamiento y ayuno, de obtener un espíritu guardián, que, ordinariamente, es un animal, $y$ en tal caso, procure matar uno de la especie y hacer con su piel una bolsa mágica, a la cual rinde una especie de culto, ofreciéndole tabaco y dándole gracias en días de ventura, implorando su socorro en la tribulación. Esta bolsa o las otras reliquias que, así, guardan del animal protector, en la major parte de las ocasiones, son amuletos (2).

(1) Lisiansky, Voyage arraund the World in Rusia Sn. Petersburgo, 1812, Vol. II, cit., por Borgas, Op. cit., pg. 384.

(2) Frazer, Totemism and Exogamy London, 1910. Vol. III, pg. 307 a 456 . 
Entre los denés, la nación más numerosa de las que moran en el Setentrión de la América del Norte y que ocupan gran parte de Alaska, y de la región del Canadá, comprendida entro el Océano Artico, la Bahía de Hudson $y$ las montañas Llilloet, hay numerosos amuletos, los cuales son, en las tribus Dogribs y Athabaskans, restos de animales, que obran por mágica simpática. Los chipewaynes nunca arrojan las redes, sin colocar en ellas algunos talismanes (1).

Entre los Tlingits que habitan un país sumamente áspero y riguroso, en medio de altas montañas, cubiertas, de seculares selvas, situadas en la costa Snr de Alaska, entre 60 y 55 grados de latitud, los cálculos que llaman daña'k, si son encontrados en el cuerpo de un ciervo, los estiman por muy pederosos para facilitar la caza de este animal (2).

Los haidas, cuya residencia está en las islas Oarlotas, usan de pequeñas lechuzas y ardillas muertas como amuletos, y las miran

(1) Lowie (Robert H.), Charms and amulets of America in Hastins, Encyclopedia of Ethics and Religion, Vol. III, Edimbourgh, 1912, pg. 404.

(2) Suanton (Jhon), Social contitions Beliefs and Linguistic Relationship of the Tlingit Indiaus 26 Annual Report of the Bureaux of Ethnology, 1904-1905, Washington, 1908. 
con respeto (1), I llaman Ilhill, Ill-jow Illjow hill, (hill=medicina o amuleto; ill -jow $=$ riqueza, prosperidad), a una figurilla humana, hecha de dos plaquitas de bronce, entre las cuales hay pedazos de tela. Este talismán, para que tenga rirtad, es preciso que haya sido robado y guardado con gran secreto, $y$ que las hilachas que llera en su interior sean sacadas de los vestidos de extranjeros. Tiénenlo en el arca, en que guardan la ropa, $\Sigma$ sólo sácanlo, cuando van a hacerle alguna petición (2).

Entre los Tbomson, una de las tribus Salish, moradores del interior de la Columbia Británica, el cazador, que no logra encontrar las presas que busca, corta la cabeza a un foolhen $y$, al llegar al campamento, le ruega que le indique la dirección en que encontrará la cacería, y la tuerce una rez; 5 , si la posición que entonces toma la cabeza la conserva, al hacer por segunda rez la experiencia, deduce que todos los animales deben encontrarse en esa dirección. Entonces coloca la cabeza, por

(1) Bencroft, The Native Races of the Pacific States of Sorth America, Vol. I, London, 1875, pg. 171.

(2) Swanton (Jonh), The Haidas of Qucen Charlotte Islands Jestup. North Pacifo Expedition, Vol. V, pg. 46, Now Fork, 1909; 
la noche, bajo su cama, con el pico hacia la dirección indicada, la cual sigue, a la mañana, en busca de cacería.

Los cazadores de osos sírvense de la cola de una serpiente, llamada de dos cabezas, como amuleto contra los azares de este deporte.

Oreen también que la piel de una marmota tiene asimismo poder para dar buena suerte en las empresas venatorias (1).

En las tumbas prehistóricas de Lytton se encuentran piedras de colores brillantes $y$ claros, grotec camente trabajadas, que dabieron ser amuletos. Parecen haber sido estos antiguos moradores de la misma cultura que los Thomson (2).

Los Lillnoeter, póximos parientes de los Thumcon, firmen ammlitus, hechos de restos de animales, nuchos basidos en magia simpática.

Entre otras tribus Salish, establecidas en la isla Vancuver los magos llevan como talismán, la piel de una especie de ardilla (3).

(1) Teit, The Thomson Indians. The Jesup North Pacific Expedition, Vol I, pgs. 3i2, New York, 1898.

(2) Smith, Archeology of Lytton British Columbia. Jesup Norh Pacific Expedition, Vol. I, New York, 1889 a 1890.

(3) Bancroft, The Native Races of the Pacific States of America; London; 1875, Vol, III; pg. 130. 


\section{RELIGIÓN DEL LMPERIO De LOS INOAS}

Dejando la costa del Pacífico, para dirigirnos hacia el atlántico, encontramos a las numerosas tribus, pertenecientes al grupo Siuan o Dacota, que ocupaban un extenso territorio, comprendido entre las Montañas Rocosas y el Misisipí. Entre éstas, era muy usado el fabricar una imagen del espíritu tutelar, el cual era en la mayor parte de los casos, un animal; dicha imagen llevan siempre consigo pues dicen influye mucho en su dueño.

Flechitas consagradas y ciertas bolsas especiales eran talismanes.

Entre los Kansas la pipa de guerra es venerada.

Los Siouan hacen amuletos con pieles do animales.

Entre los Jowas, además de los objetos ya dichos, son talismanes, ciertas piedras redondeadas $y$ un pedazo de hierro.

Los jefes y guerreros Assinniboines tienen un wakan o amuleto, que consiste ya en la piel de un animal o en las plumas de un pájaro, ya en una pequeña piedra, ya en una figura fantástica, dibujada con mullos (1).

(1) Dorsey, (James Owen), A Study of Siouan Cults $11^{\text {th }}$ Annual Report of the Bureau of Ethnology, 1889 a 1890 , Washington, 1894 , pgs. 413 a 416, 426 y 427, 448, 499. 
Entre los Hidasta, todo hombre tiene una medicina personal, que es ordinariamente, la piel, las garras, la cabeza o algún otro resto del animal que tienen por su espíritu guardián; entre los cuales opinan los más poderosos son el búfalo blanco, la zorra y el lobo.

Los dientes de los osos son amuletos muy preciados, que cuelgan al cuello de las muchachas, para que sean industriosas $y$ trabajadoras.

Para asegurar la agilidad de un potro, que esperan llegne a ser un buen caballo atan a su cuello un pedacito de cuerno de ciervo o antílope (1).

Para los Ojibwayes, que pertenecen al stok Algonquín y que ocupan un extenso territorio, al rededor de los lagos Hurón y Superior, el primer hecho importante en la vida de un joven es su primer ayuno, para el cual abandona la casa paterna y so establece en un lugar solitario, donde se abstienen de alimentos hasta que el hambre y la fatiga le ponen en un estado histérico o estático, durante el cual

(1) Mattheus (W.), The Hidasta, Washington, 1877, pg. 50.

Dorsey (James Owen), A Study of Siouan Cults 11 th Annual Report of the Bureau of Ethnology, Washington, 1894, pgs. 610 y 515 . 


\section{ReLigión DeL IMPERIO DE LOS INOAS}

tiene la visión de su espírita guardián, que es el objeto que primero se le aparece en su semidelirio $y$ al cual nunca menciona, sin ofrecerle antes un sacrificio.

Hacen una imagen de este manitu, ya tallada, ya dibujada, la cual llevan siempre sobre sí, colgada al cuello o en la bolsa mágica (1).

Los Blackfoot, otra tribu Algonquín, situada en las vertientes orientales de las Montañas Roqueñas, matan un animal de la especie a que pertenece su espíritu guardián $y$, con gran sigilo, conservan su piel como valioso amuleto (2).

Los Iroqueses consideran la mayor parte de las cosas que les parecen extraordinarias como oki, y el que halla una de éstas, tiene por asegurada su ventura. Así, guardan esmeradamente los cálculos que encuentran en los animales que cazan y cualquiera otra cosa sin-

(1) Hoffman, The Midê' wiwin or grand Medicin Society of the Ojibwa $7^{\text {th }}$ Annual Report of the Bureau of Ethnology 1885-86, Washington, 1891.

(2) Wilson, Report on the Blackfoot Tribes, pg. 187. Report of the $57^{\text {th }}$ meeting of the British association for the Advencement of Science held in Manchester in 1887, London, 1888. 
gular, a tales objetos honran en sus fiestas y propician con sacrificios (1).

Para defenderse del mal de ojo, llevan collares $\mathbf{u}$ aretes de amuletos. Estos son figuras o caras humanas o restos de algún animal (2).

Un hurón, si ha tenido dificultad especial para matar un ciervo $y$ en sus entrañas encuentra alguna piedra, guárdala como objeto dotado de poder sobrenatural y empléalo como amuleto (3).

Entre los Creek, que pertenecen a la familia Muskhogeana y que, cuando la conquista francesa de 1730, vivían en los actuales estados de Alabama y Georgia, los mozos arentureros, que se armaban, de tiempo en tiempo, en partidas guerreras, llevaban como prenda de ventura una bolsa talismán, que guardaba el conductor de la expedición, que era un brujo o profeta (hob'aya). Esta bolsa contenía un

(1) Spence (Lowis), Fetichism of America in Hastings Encyclopaedia of Ethics and Religion, Vol. V, Edimbuurgh, 1912, pg. 900.

(2) Dorman (Rushton), The Origin of primitive Superstitions among the Aborigins of America Philadelphia, 1881, pg. 160 .

(3) Lowie (Robert H.), Charms and Amulets of America in Hastings, Op. cit., Vol. III, pg. 403. 
amnleto, hecho, según rezaba la tradición, con el cuerno de una serpiente y hojas de cedro (1).

Volviendo a las costas del Océano Pacífico, notaremos, en primer lugar, a los Nez percé, que viven en el Oregón, quienes cuelgan de los árboles cuernos de ciervos, para que la snerte les sea propicia.

Los amuletos de estos indios eran, a menudo, pequeñas piedras, on la mayor parte de los casos, sin trabajo alguno, y que tenían algo de notable en su forma o color, apreciando, de un modo especial, las perforadas naturalmente. Sucedía, a veces, que uno de estos amnletos fuese posteriormente labrado por su dueño.

Servíanse también para talismanes de las garras de un oso o de los dientes de un lobo (2).

Los cálculos de los ciervos, que llevan colgados al cuello, son amnletos para los cazadores Maidus, que residen en la Oalifornia

(1) Speck, The Creek Indians of Taskig Tow. Memoirs of the American Anthropological Association, Vol. II, pg. 118, Lancaster, 1907.

(2) Spinden (H. J.), The Nez percé indians Memoirs of the American Anthropological Association, Vol. II, pg. 260, Linciaster, 1008 . 
Oentral, los cuales se sirven también, con igual objeto, de piedras raras o singulares (1).

Mayor importancia tiene el conocimiento de los amuletos de los indios Pueblos que el de las otras naciones enumeradas anteriormente; pues las tribus que moran en el Arizona y Nuevo México, se encuentran en un estado de cultura más parecido al de los Antiguos Peruanos que otros indios de la América Setentrional, ya que son, sin disputa, los pueblos los más civilizados de todos los aborígenes de la porción norte del Nuevo Mundo. Razón por la cual han sido más repetida $\mathrm{y}$ atentamente visitados por arqueólogos y etnógrafos, quienes han encontrado riquísimo material para sus estudios en las ruinas de antiguas construcciones, de que llenan las altas mesetas y los profundos cañones, y en las sociedades secretas $y$ otras instituciones de estos interesantes aborígenes, los cuales, si tienen todos un mismo tipo de cultura y parecida organización social, pertenecen, filológicamente, a cuatro grupos diferentes.

(1) Lowie (Robert H.), Charms and Amulets of America in Hastings Encyclopaedia of Ethics and Religion, Edimbourgh 1912, Vol. III, pg. 405. 
Los Hopis son los más occidentales de estos indios y moran en la frontera de Nuevo México y Arizona, y hablan una lengua perteneciente al grupo Shoshoneo. Entre ellos, cuando se acerca el desembarazo, la mujer lleva en su canasta cuando va al bosque por leña, un cuchillo de piedra blanca (1).

Más conocidos y populares entre los estudiosos son los Zuñis que viven todos en an solo pueblo, cerca del río de su nombre, y que hablan un lengnaje propio, independiente de los otros Pueblos.

Cushing, cuyos escritos sobre estas gentes son una de las obras clásicas del Americanismo, nos servirá de guía en nuestra exposición de los amuletos o fetiches zuñiz, que de ambas cosas tien $n$.

Los Zuñis o, como ellos se llaman a sí mismos, los A-ski-wi, suponen que el sol, la lana, todos los fenómenos y elementos, las estrellas, el cielo y la tierra, los seres inanimados, las plantas y animales pertenecen a un sistema de vida consciente y entrelazada, en el cual los grados de relación se determinan por las semejanzas. El

(1) Pleny Earl Goddard, Life and Culture of the Hupa University of California Publications on American Ethnograjhị and Archoolögy, Brejeley, 1903-1904, yg. 5il. 
poder relativo de cada uno de los entes mídenlo por el del misterio que le rodea; $y$ como para el hombre (por lo menos, aparentemente) es el hombre el sér mejor conocido, tiénenlo por el sér menos poderoso de la creación.-Los amaletos de los zuñis son: concreciones naturales, piedras que presentan semejanza con un animal, desprovistas, en algunas ocasiones de toda labor, en ótras, trabajadas en forma de animales; encontradas estas últimas en las ruinas de los antiguos pueblos o trasmitidas, durante machas generaciones, de padres a hijos.

Para explicar el origen de estos amuletos cuentan que, en un tiempo may remoto, los hombres vivían en el interior de la tierra, en una cueva oscura y estrecha, encima de la cual había otras tres, cada una más grande y más clara que la inferior. En la primera caverna, los hombres se multiplicaron y llegaron a estar may estrechos e incómodos. Compadecido entonces el Sol, engendró dos hijos, que envió a donde los humbres, dotándoles de perpetno vigor y de mágicas armas. Estos 'accediendo a los deseos de la humanidad, fuéronla sacando de caverna en caverna, cada vez que la inferior venía estrecha al número siempre creciente de sns moradores. Al llegar a la superficie, los Hijos .... 
del Sol vieron que la tierra había sido desolada por un diluvio y que estaba llena de animales feroces. Al ver esto, sirviéndose de las armas que les había dado su padre y que tenían el poder del rayo, hicieron correr fuego sobre la faz del mundo, para secarlo y consolidarlo. Hecho lo cual viendo los grandes males que a los hombres hacían las bestias $d \theta$ presa, recorrieron el orbe, fulminándolas y ordenándoles que su gran poder, casi divino, que hasta entonces habían empleado en hacer mal al hombre, lo nsasen, en adelante, en servirle. Los animales, así beridos del rayo, convirtiéronse en piedras, $y$ éstas son las que hoy sirven de amuletos a los zuñis los cuales, si, por su forma natural o por el que les ha dado el primitivo escultor, recuerdan algún animal conocido, o identifican con éste; $y$, si presentan formas extrañas, asegura corresponden a especies desaparecidas.

Estos talismanes pertenecen a seis categorías principales, correspondientes a puntos determinados del horizonte; $y$, en cnanto protectores de la caza, son: el león de la montaña para el Norte, ol coyote para el Oeste, el lobo para el Este, el gato salvaje para el Sur, el águila para el Cenit y el topo para el centro 
de la tierra. Oada nna de estas especies está dividida en seis variedades, según el color del amuleto, que depende del pigmento que lo recubre o de la materia de que está fabricado.

Las seis especies varían ligeramente, cuando no tienen relación directa con la cacería. En este caso, son: el león de la montaña, el oso, el bedger, el lobo, el águila 5 el topo.

Estos amuletos son, casi siempre, propiedad particular; pero cuando no están en uso, los guarda, en jarros antignos, el Ouidador de la Magia del Oiervo (Keeper of the Deer Me. dicine).

Además de estos talismanes antiguos y tradicionales, sírvense los zuñis de ótros, en forma de caballos tallados en piedra, que compran a los Navajos, que llevan cuando ran a cazar o montados; pues dicen que dan resistencia a la cabalgadura. Sírvense también de ótros en forma de carneros, para que sus rebaños se acrecienten.

Fuera de los enumerados, tienen infinidad de otros amuletos, los cuales son 0 cantos extraños por su forma, que dicen ser parte de algán dios, o de sus adornos, armas o reliquias, que aseguran baber sido dadas a los hombres por los diuses, on los tiempos primitivoos (days 
of new), o medicinas mágicas, que protegen de enfermedades o son agentes de reproduc. ción (1).

Entre los Sias, cujo pueblo está en una altura sobre el río James, tributario occidental del Río Grande, y que hablan un idioma perteneciente al grupo Keresan, en el momento del parto, el padre coloca sus manos al rededor de sus rodillas, teniendo un amuleto en la palma de la derecha, mientras la cuñada de la paciente, de pie, a la izquierda de la mujer, coloca una mazorca de maíz en la cabeza de la enferma, sobre la cual sopla durante los momentos de dolor, para apresurar el desembarazo (2).

Los apaches, cuyos parentescos étnicos deben buscarse en las regiones, limítrofes a la Bahía de Hudson, y en Alaska, que viven cerca de los indios Pueblos y puede decirse en constante guerra, hacen collares con los dedos de los enemigos vencidos, no sólo como trofeo y timbre de honor de la victoria, sino

(1) Frank Hamilton Cushing, Zuni fetiches Second Annual Report of the Bureau of Ethnology 1880-1881, Washington, 1883 , pgs. 9,11 a 15 o 16 a 39 y 44 a 45 .

(2) Matilda Coxe Stevenson, The Sia 11 th Annual Report of the Bureau of American Ethnology 1889 a 1890, Washington, 1884. 
principalmente como talismán para vencer, no sólo al enemigo, sino también al espíritn de éste, a quien se espera esclavizar de este modo (1).

(1) Bourke (John G.), The Medicin Men of the Apache $9^{\text {th }}$ Annual Report of the Bureau of Ethnology, 1887-1888, Washington, 1892, pgs. 480 a 487.

Muy común es entre los primitivos el temor de los males que puede causar el espiritu de un hombre a aquél que le ha dado muerte, y para evitarlos, se ha recurrido a prácticas que repugnan a la delicadeza de los civilizados; pero que no son refinadas crueldades, sino medios para defenderse del alma del difunto. Así, ya han tratado de adquirir la amistad del espíritu comiendo el cuerpo del muerto o bebiendo su sangre, ya de esclavizarlo conservando una reliquia del difunto como trofeo y talismán.

La primera de estas explicaciones es aquella que conriene a buena parte de festines de antropófagos y a otras costumbres semejantes (Frazer, The Golden Bough, Vol. III, pg. 157, London, 1914).

La segunda explica la difundida costumbre de conservar la cabeza u otro miembro del muerto, creyendo así, asegurar la posesión del espíritu con la de los restos que guardan, basándose en los mismos principios de mágica por contacto, por los que se cree ejercer dominio sobre un sujeto, poseyendo sus cabellos.

De este modo, debe interpretarse la costumbre de llevar colgada del brazo la calavera del vencido, observada en el Perú, durante los períodos de Nazca y Tiahuanaco, como puede verse en numerosos vasos de la primera de las citadas épocas, (Uhle, La esfera de influencia del Pays de los IncasRevista Histórica, Lima 1909, Vol. IV, pg. 10), y en la figura central del más fanoso monumento de la segunda, la Puerta del Sol de Tiahuanaco (Stubel and Uhle, Uber der ruinostate von Tiahuanaco Lám. VIII, Berlín 1892).- En Fray Gerónimo de Oré se lee "en la provincia de los Collahuas (ro- 
En sus actos religiosos o mágicos, sírrense estos indios de un polen al cual atriburen grandes rirtudes r que llaman hoddentin. Sírrense también, con igual fin, de margagita 5 antimonio en polro; solamente que los usan con más parsimonia, por ser más raros 5 preciosos.

gión Aymara) conoci un indio qe tenía guardada una camiseta sembrada toda ella de uñas de indios que sus abuelos auian muerto". (Ore, Símbolo Catćlicu Indiano, Lima, I598, pg. 391 .

A iguales motiros deben ubedecer ias fimosas tzantzas de los Jíbaros r las cabezas de lus Muuluricus, Simoens da Silva, Cabezas Indigenas rartefat s de piedia del Brasil. Boletín de la Oficina Naciunal de Estadistica. La Paz, 1900, pg. 367. Hamy Decades Amerivanæe. 3a. Decades, Paris, S. D. pg. 52 y sig).

Los Comanches cortaban las orejas de los enemigos muertos $y$ con ellas furmaban ristras, proceder que, a titulo de represalias, fué adoptado por los mexicanos de Sonora en una de tantas guerrillas que sosturieron, a mediados del siglo XIX, con estos indios, que de tiempo en tiempo, desolaban las haciendas situadas en las regiones confinantes a las habitadas por dicha tribu.

El guardar las cabelleras de los muertos es uso común entre las tribus norteamericanas. Los Osages plantan en sus tumbas un palo del que cuelga la cabellera del rencido. Los Algonquines conserran, no sólo la cabellera, sino los dedos, las manos $y$ los pies; los Californianos, las cabezas, los pies $\mathrm{y}$ las manos. (Dorman, Op. cit., pgs. 143 y 114). - El autor rió un pie reducido a la manera de las tzantzas de los Jibaros, que se decía haber sido hallado en una tumba de Imbabura (República del Ecuador). 
Llaman $i=z e k l o t h$ a una cuerda, que forma parte del restido sagrado de los brujos $\mathrm{I}$ de los iniciados en las sociedades secretas, de la cual cuelgan, frecuentemente, figurillas humanas, recortadas en una tabla $y$ pintadas con líneas en zigzag, símbolos del rạo. Estas figarillas dichas $t z i-d a l-t a i$, son amuletos que nunca faltan a los Apaches, I que, a reces colocan en las cunas (1).

Los Seris de California se entierran con sus amuletos, que son muñequitos de barro, de forma humana (2).

Al tratar de los talismanes de los aborígenes de la América Central y Meridional, may a pesar nuestro, tendremos que ser más breres; puesto quo, deseando serrirnos en nuestro rápido estudio de datos etuográficos, y no arquelógicos, 5 estando, por dicersas razones, aún muy ignorada la etnografía de la América española, nuestras informaciones al respecto

(1) Bourke (John G.), The Medicine men of the Apache 9tu Annual Report of the Bureat of Ethnologr, 1887 a 1888 , Washington, 1892, pgs. 548550.553 y 587.

(2) MC Gee (T. J.), The Seri Indias $1 \pi^{\text {th }}$ Anuual Report of the Bureat of American Ethnology 1895-1896, Washington 1898, pg. 290. 
son mncho más deficientes que para la parte norte del Continente (1).

Los Coras, que viven en el Norte de México, hacen talismanes con hilos de diferentes colores, dispuestos con elegancia, formando un pequeño tejido poligonal. Su fabricación da lugar a varias ceremonias; $y$, si han de ser eficaces, es preciso que a ellas asista aquel a quien están destinados (2).

Los Huicholes, sus vecinos, que moran en el estado de Sonora, dicen que los cristales de roca son personas misteriosas, muertas o vivas; que los brujos, despnés de haberlas hecho atraresar los aires, en forma de un pajarito blanco, las han cristalizado. Llaman a estos cristales abuelos, y creen dan prosperidad en la caza, y ambicionan poseer el mayor

(1) Antes de pasar adelante, no creemos sea inútil mencionar los amuletos de los pueblos no aborígenes de los Estados Unidos de América, entre los cuales se hacen talismanes de huesos de pescado, de cangrejos, de tortuga, con el condilo del fémur de un cerdo, con plumas $y$ huesos de ciertos pájaros, con pieles de conejo o de serpientes y con pequeños guijarros. Bergen (Fany), Animals and Plants Lore-Colected from the Oral traditions of the English Speaking fool. Memoirs of the American Folk-Lore Scciety, Vol. VIII, pgs. 11-13, Boston 1913.

(2) Lumhotlz (Carl), Unknown Mexico, New York, 1902, Vol. 1, pg. 521. 
número posible de éstos, y hay indios que llegan a tener hasta diez y los guardan cuidadosamente en un lugar reservado de la casa.

Tienen, además, otros talismanes, formados por dos carrizos, atados en cruz, entre los cuales tejen, con hilos de diferentes colores, un rombo (1).

Entre los Otomíes, una mujer que va a ser madre es víctima de muchas privaciones $y$ sufrimientos, a causa de sus prácticas supersticiosas; cárganla con ciertos amuletos y sométenla a innumerables tabús (2).

Los amuletos aztecas eran figurillas de pequeñas dimensiones. Llamábanlos tepictoton, que es el plural de la roz tepicton, que significa pequeño. Los antiguos escritores los comparan a los penates de los romanos, como lo hacen con los conopas peruanos. Los reyes $y$ caudillos podían tener seis de estas figurillas, cuatro los nobles $\boldsymbol{y}$ dos los plebeyos.

De estas imágenes había profusión en las calles $y$ caminos lo mismo que en los campos;

(1) Lumholtz (Carl), Unknown Yexico, New York, 1902, Vol. II, pg. 198 y 211.

(2) Bancroft, The native races of the Pacific States of N orth America. London, 1875, Vol. I, pg. 634. 
pues los tenían por protectores de todas los $\operatorname{cosas}(1)$.

Los tepictoton o pequeños erau diminutas figuras de los espíritus de las montañas, tales como el Popocateptl, el Iztac-tepetl, el Matlacuefe, el Chalchiuhtlicue y del dios Quetzalcoatl, llamabanles también tlaloques y les atribuían causar la lluvia (2).

Hacían también talismanes con reliquias del cuerpo de una mujer, que moría al dar a $\operatorname{luz}$.

Como amuletos deben también quizás clasificarse los bastones negros, de que se servían los caminantes $y$ a los cuales, al fin de la jor-

(1) Torquemada, Monarchia indiana, Madrid, 1723, Fol. II. pg. 64 .

Clavigero, Storia antica del Messico, Cesena, 1780, Vol. II, pg. 23.

Robello, Diccionario de Mitología Nahoa. Anales de Museo de México, Vol. V, pg. 227, Méxice, 1908.

Bancroft, The natice races of the Pacific States of North America, London, 1875, Tol. II, pg. 269, Vol. III, pg. 419.

Dorman, The Origin of primitive superstitions, Philadelphia, 1881, pg. 71 .

Lewis Spence, Charms and Amulets of Mexicans and Mayans in Hastings Enciclopaedia of Ethics and Religion, Vol. III, pgs. 455 y 456 .

(2) Seler, Costumes et attributs des divités du Mexique, selon le P. Sahagun. Journal de la Societé des Américanistes de París N. S. Vol. VI, pgs. 142-145, Paris, 1909. 
nada, adoraban, identificándolos con Jacatcutli, dios de los viajeros.

La fábrica y renta de los talismanes era, ordinariamente, beneficio exclusiro del sacerdocio (1).

Los ampletos de les inlios de $\mathrm{Hon}$ luras

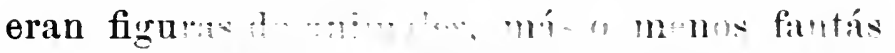
ticas, $\operatorname{chos}(2)$.

Los Nicoyas 5 otras tribus de Costa Rica hacían talismanes tallidos en piedra, algunas veces, en forma de hachas (3).

Los Ohiriquíes, para protegerse de influencias nocivas y tener buena suerte, llevaban collares con figurillas de animales, garras de bestias feroces $y$ plumas (4).

Los Antillanos llevaban sus amuletos, atados al tocado o colgados del cuello.

Los arqueólogos están de acuerdo al reconocer por talismanes a ciertos objetos pequeños de piedra, de formas antropomorfas o zoomorfas, y casi siempre perforados; mas estos

(1) Autores citados en la nota $1^{\mathrm{a}}$. de la página anterior.

(2) Dorman, Op. cit., pg. 156.

(3) Lowie (R.), Charms and Amulets of America in Hastings Encyclopaedia of Ethics and Relihion, Vol. III, pg. 408.

(4) Dorman, Op. cit., pg. 158. 
aborígenes tenían también amuletos de otras materias, tales como concha, dientes de cocodrilo, etc., etc. (1).

A los indios de la Guayana no les faltan amuletos, que en caribe se llaman turallari en waru aibihi y en àrawak binces, roz derivada de bia o bina, que significa atraer, halagar. Son estos amuletos siempre objetos orgánicos, exceptuándose tan sólo, las piedrecillas de cuarzo que hay en las sonajas le los brujos (maracas).

Para tener felicidad en la caza, cultivan con esmero ciertas plantas, que son binas, $y$ que dicen antiguamente las obtenían de grandes serpientes.

May raras son las binas de caza de origen animal.

De origen rejetal son también las binas para el amor $y$ toda mujer tiene la suya. Las muchachas arawaks cnltiran cuidadosamente en un lugar escondido, la planta que es su bina, $\boldsymbol{\Sigma}$ se bañan sirriéndose de una de sus bo. jas, $y$ si les es posible frotan con ella la hamaca de sn amante, o se frotan las manos antes de acariciarlo. Los hombres tienen tam-

(1) Fenks (Walter), The Aborigines of Porto Rico and Neighboring islands 25 Annual Report of the Burean of Ethnology, 1903-1904, Washington, 1907 
bién su talismán amatorio, con el que procuran frotar a la mujer que quieren.

Los moradores de Guayana tienen talismanes para librarse del mal de ojo, defenderse de influencias nocivas, $y$ para obtener ciertas virtades o cualidades físicas $y$ morales.

En Pomerun, la cola y las manos de un alacrán puestos en la cintura de una muchacha, hará que cuando sea mujer, las bebidas que fabrique, sean muy fuertes $y$ gustosas.

Entre los Arawaks los dientes de tigre harán al muchacho que los lleva sobre sí, hombre fuerte y rigoroso, libre de todo ataque de animales feroces.

Las mujeres Makusi, así como los muchachos, usan collares de dientes de tigre, que juzgan tienen virtudes mágicas.

Los caribes creen que los dientes de cocodrilo son talismanes poderosos, $y$ en el Oeste del Orinoco tiénenlos por antídoto contra ciertos venenos (1).

Los Goagiras llaman guaras a unos amn-

(1) Walter E. Rosh, An Inquiry into the Animism and Folk-Lore of the Guiana Indias, 30 th Annual Report? of the Bureau of American Ethnology 1908-1909, Washington 1915, pgs. 234 y 281 a 290. 
letos muy estimados; a aquellos que los poseen, los tienen por ricos y poderosos.

Los guaras, envueltos en huata, son preciosamente guardados en cajas, de las cuales sólo una vez al año los sacan para bañarlos.

Raros son los felices dueños de objetos tan preciosos, no sólo para aquellos salvajes, sino también para los civilizados, pues son de oro.

Más numerosos son los keiresia y no pocos los que los poseen; parécense mucho a los guaras, pero, tanto por su precio intrínseco como por sus virtudes sobrenaturales, valen mucho menos (1).

Los Ohibchas tenían en sus casas muchas figurillas de barro y, a veces, de oro, que guardaban con gran devoción. Estos eran sus amuletos (2).

Los Paeces, moradores del valle del Cauca, tenían amuletos que, como los de los Chibchas y de la mayor parte de los antiguos moradores de América española, han sido comparados a los lares y penates de los romanos. Los de

(1) Candelier, Le Rio Hacha et les indiens Goagires, Paris, 1893, pg. 186.

(2) Restrepo, Los Chibchas antes de la Conquista Espa. ธola, Bogotá, 1895, pg. 50. 
estos indios eran las figuras talladas en madera, que se encontraban, a menudo en sus casas (1).

No escasean entre los araucanos, dice un respetable autor, «los talismanes u objetos mágicos que comunican el bien. De ordinario son piedras negras o de pedernal transparente. Los indios las entierran en el corral para conseguir la reproducción de los animales y evitar su pérdida, o bien las guardan en el granero para prolongar la duración de los cereales » (2).

Entre los mestizos que moran actnalmente en la región Diagnita (N. O. argentino), se encuentran figuritas, llamadas illas, representaciones de animales domésticos, llamas, corderos, bueyes. Son éstos, talismanes para proteger los rebaños contra toda suerte de peligros y para favarecer su reproducción. Otra forma muy frecuente de illas es una mano que cierra un objeto parecido a un bastón; a veces, tiene un círculo grabado en el interior, que representa una moneda. A estas manos dan el nombre quichua maqui y se les atribuje vir-

(1) Pittier de Fabreqa (H.), Ethnographie and Linguistic Notes on the Paez indians of Tierra adentro Cauca, Colombia, Memoirs of the American Antropological Association, Vol. I, pg. 325, Lancaster, 1907.

(2) Guevara (Tomas) Folklore Araucano Santiago, 1911, pg. 261. 
tad para adquirir fortuna $y$ hacer bnenos negocios. Estos amuletos son importados de Bolivia y fabricados por los curiosos indios Oollahuayos, los cuales recorren gran parte de la América del Sur, vendiendo drogas y talismanes (1).

Son muy rariados los amuletos que fabri. can los Collahuayos, siendo la mayor parte figurillas de alabastro, que representan ya animales ya hombres. Estas singulares gentes, originarias de Muñecas, provincia boliviana situada al Noreste del lago Titaca, de lengua quichua; son intrépidos viajeros que recorren grandes distancias, pues vada extraño es encontrar a estos médicos ambulantes, en Guayaquil y en Buenos Aires, visten un traje especial y viajan por toda la altiplanicie, bien recibidos y respetados por todos los indios, vendiendo los amuletos que fabrican así como drogas, más o menos mágicas (2).

(1) Boman, Antiquites de la Region Andine de la Republique Argentine et du desert d'Atacama, Paris, MDCCCCVIII, pg. 134.

(2) Nordenstiöld Recetes Magiques et Medicales du Perú et de la Bolivie. Journal de la Societé des Americanistes de Paris N. S., Vol. IV, Paris, 1907, pg. 153-174.

Bandelier, The Islands de of Titicaca and Koaty, New Yok 1910, pg. 154 y sig. 
Los actuales moradores de la paná de Jaguy tienen la costumbre de florear, como ellos dicen, sus llamas, colocando a algunas de las del rebaño, borlitas de lana roja, que ha sido torcida a la izquierda y no a la derecha, como la lana ordinaria. Estas llamas, así adornadas, son tenidas por protectores del rebaño (1).

En la región de la República Argentina dicha Misionera, los amuletos son llamados payes. El paye es casi siempre personal, fabricado ad hoc y destinado a un fin determinado. El amuleto necesita un cuidado especial; $y$ así cuando en su composición entra la piedra imán, es preciso darle de comer de tiempo en tiempo, esto es agregarle pedacitos de agujas.

En la composición de algunos payes hay elementos cristianos. La posición de un paye obliga, en ciertos casos, a determinadas privaciones, verdaderos tabús, sobre todo sexuales (2).

Para ablandar al corazón de una mujer llevan en la región misionera en el bolsillo, un envoltorio que contenga una mezcla de se-

(1) Boman, Op. cit., pg. 497.

(2) Ambrosetti Superticiones $\mathrm{J}$ lejendas. Rejión Misionera, Valles Calchaquis, Las Pampas. Buenos Aires, 1907, pg. $41 \mathrm{y}$ sig. 
sos, vermellon y plumas de Caburey (glauci. dinn ferox) (1).

Ninguna india Caingua resistirá a los requerimientos de un galán que le muestre un pedazo de vermellón, pues temerá llenarse de horribles llagas (2).

Los abipones, para librarse de las picaduras de las serpientes, llevan collares, hechos con dientes de cocodrilos (3).

Los indígenas dei Brasil llamaban muirakitans a sus amuletos, que eran piedras tomadas a la orilla de un lago o huesos de animales, que se introducían en las mejillas $u$ orejas (4).

Amuletos son también, probablemente, los sonajas de los Tupinambas, hechas con la fruta, llamada maraja, en la cual, una vez seca, introducen piedrecillas y fijan una caña, que sirve de mango. Eran estas sonajas tan sagradas, que sólo el dueño podía mirarlas: creían que daban oráculos y les hacían sacri-

(1) Ambrosetti Materiales para el estudio del Folk-lore Misionero, Buenos Aires, 1894, pg. 29.

(2) Ambrosetti, Los indios Caingua del Alto Parana. Burnos Aires, 1895 , pg. 741.

(3) Dorman, Op. cit., pg. $15 \mathrm{~s}$.

(4) Id. id., pgs. 156 y 159. 
ficios. En la extremidad de la caña no era raro el que colocaran la cabellera de un vencido (1). Los Arannas, que viven cerca del río Madre de Dios, tienen muchos guijarros, de los que esperan abundantes cosechas de maíz, de yuca y de otros productos, buena pesca y oportunas lluvias (2),

En el Napo se crée, que brazaletes y ajorcas de piel de iguana, dan valor y fortaleza a quien los usa (3).

Los indios del Amazonas fabrican amuletos $\mathrm{g}$ atribuyen a únos poder sobre las aguas, a ótros sobre los sembríos, sobre la guera, etc., etc. No usan con ellos de ninguna ceremonia ni adoración; mas los tienen olvidados y arrinconados hasta cuando han menester de ellos. Si ran a la guerra, colocan en la proa de sus embarcaciones el amuleto que creen les dará la victoria, y así en los demás casos (4).

Terminada la reseña antecedente, que nin-

(1) Dorman, op. cit., pg. 160.

(2) Earl Churche 'George', Aborigines of South America, London, 1912, pg. 146.

(3) Walter E. Rolh An Inquiry into the Animism and Folk Lore of the Guiana Indians 30 th Annual Report of the Bureau of American Ethnology, 1908-1909, Washington 1915.

(4) Acuña (C.), Nuero descubrimiento del gran rio de las Amazonas, Madrid, 1641, folio 18 verso. 
gana pretensión tiene de ser completa $\boldsymbol{y}$ cuyo solo fin es el de servir de comparación $y$ esclarecimiento a lo poco que, acerca de los conopas peruanos sabemos, podemos tratar de sacar algunas consecuencias, ya que todos los amuletos americanos presentan ciertos puntos de contacto $y$ las costumbres examinadas en las páginas anteriores explican la mentalidad de los súbditos de los Incas, incomprensible, de otro modo, para nosotros, no sólo a causa de nuestra mentalidad, esencialmente diversa de la de los primitiros, sino aún más a causa de las falsas ideas que, sobre el desarrollo religioso de Tihuantinsuyo, son corrientes entre los escritores más autorizados, como en los capítulos posteriores pondremos de manifiesto.

Los amuletos, al desarrollarse las religiones, si no han perdido su popularidad, hanse vuelto cada día menos individuales y más fácilmente distinguibles del fetiche. No así en las religiones rudimentarias, en aquellas en que los dioses, más que seres personales, son encarnaciones o receptáculos de fuerza mágicoreligiosa.

Los porte-boneurs modernos son objetos destituídos de toda idea de indiridualidad, imágenes, signos o inscripciones, de las cuales se 
espera, de un modo más o menos inconsciente, cierta vaga ayuda o protección. Su eficacia es siempre igual, siendo igual el talismán; su virtud no está vinculada a tal o cual objeto; sino a la forma, o al dibujo, o a la materia; y siempre que remen una de estas cualidades o de todas ellas se obtiene un amuleto de igual potencia.

Los elefantes, las estrellas, las hojas de trébol, los números treces etc. etc., que, al infinito, reproduce la joyería contemporánea y que encuentran siempre fácil 5 segura renta, merced a los profundos y arraigados sentimientos supersticiosos, que los siglos de cultura no han logrado destruir en el espíritu del hombre civilizado, son todos iguales entre sí, dotados todos de igual potencia; $y$ si uno se pierde o rompe, siempre podrá reemplazárselo, sin que la seguridad o felicidad de su dueño se menoscaben.

Mas no son estos dijes los únices amuletos supervivientes en las modernas sociedades; que las medallas, escapularios $y$ otros objetos piadosos semejantes, hijos son del primitivo amuleto. En estos, nótase con más claridad la evolución del talismán, colrespondiente al desarrollo religioso; pues el más ligero obserReligion del Imperio de los Inces 
vador advertirá que la medalla o escapulario no tienen ninguna virtud inherente; que su poder proviene tan sólamente de la protección del santo a que está consagrado, y cuyo favor se espera obtener llevando su imagen o símbolo; pues si uno de estos objetos piadosos, se pierde o destruye puede reemplazárselo por otro semejante, sin que la protección del nuevo sea inferior o superior a la del antiguo. $Y$ no puede arguírse contra lo dicho el dolor que algunas reces causa la pérdida de uno de estos objetos; porque esto depende de circunstancias extrínsecas a su rirtud.

No así el amuleto americano, que siempre está dotado de entidad propia, exceptuándose tan solamente los tepictoton de los mexicanos, diminutas imágenes de algunas de las grandes divinidades de México, figurillas, cuyo poder proviene del de la divinidad que representaban, esto es, amuletos sin individualidad (1).

A la individualidad de los amuletos americanos parece, a primera vista, constituyen también una exepción los animales de presa de los zuñis; mas, si bien se observa, lo es

(1) Vide supra, pg، 160. 
tan sólo aparentemente, ya que son concreciones naturales, piedras desprovistas de toda labor, que por casualidad tienen alguna semejanza a un animal, o son representaciones zoomorfas, trabajadas por los moradores de los antiguos pueblos $y$ trasmitidas, durante muchas generaciones, de padres a hijos (1), esto es, que por su naturaleza, por su origen, son talismanes. Son animales casi dirinos petrificados por los formadores del mundo, para que sus poderes sobrenaturales los empleen en servicio de la Humanidad, siendo, por lo tanto, cada uno de ellos un ente independiente e individual. Mas, por otra parte, no puede dudarse de que sa clasificación en tipos determinados, relacionados con un punto fijo del horizonte (2), constituye un gran paso en la evolución del amuleto viro al amuleto símbolo o fórmula mágica.

Más sería dificultad a la teoría que ramos exponiendo, $y$ es la que se suscita del estudio de los amuletos coras $y$ huicholes, en forma de rombos, tejidos con hilos de diferentes colores (3); si

(1) Vide supra, pg. 140 y sig.

(2) Vide supra, pg. 142.

(B) Vide supra, pg. 148 y 149. 
bien, quizás, se puede opinar que también éstos están dotados de cierta individualidad, ya que su virtud, depende de los ritos que debeu practicarse al tiempo de hacerlos y sólo son eficaces para proteger a aquel para quien fueron bechos, y tan solamente si ha permanecilo junto al brujo durante todo el tiempo que éste ba empleado en hacerlos.

En los demás casos, cuando los datos de que disponemos son suficientes para esclarecer la verdadera naturaleza de los amuletos, encontramos que tienen indiridualidad.

Dos ejemplos nos servirán como demostración, acudiendo con este fin, a las dos clases de objetos, de que se hace más frecuente mención en la reseña antecedente, a saber: las piedras de formas raras $y$ las reliquias de anima. les. En cuanto a la primera, las preciosísimas observaciones hechas entre los koriyak por Krasheninnikoff no permiten dudar de la individualidad de los amuletos de ese pueblo, ya que sabemos que un lioriyak enfermo encontró una piedra, Ja cual echándole su aliento, esto es dándole una manifiesta señal de su vida oculta, le expresó el deseo de que la recogiese, y como no accedió al deseo de la piedra y no la tomó, agraróse del mal que padecía sin du- 
da, porque la piedra irritada quería castigarle; mejorándose cuando la recogió y honró (1).

Los talismanes de los chuckchis son aquellas piedras que, de algún modo, han demostrado voluntad de servirles (2).

No menos clara aparece la individualidad de los guijarros de forma rara entre los $\mathrm{zu}$ ñis, ya que aseguran que son adornos, armas o reliquias de los dioses, dados por éstos a los hombres en los días de la formación del universo (3), y en los cristales de roca de los huicholes, hombres cristalizados por obra de encantamiento (4).

Mas, desgraciadamente, si muchos autores hablan de los amuletos, hechos de piedras raras, pocos nos revelan lo que sobre estos piensan sus dueños; pero los hechos, que acabamos de citar, son suficientes para establecer nuestro criterio al respecto y deducir, lógicamente, que esta clase de talismanes entre los pueblos primitivos es siempre individual; deducción a la cual corroboran ciertas consideraciones que haremos en su lugar.

(1) Vide supra, pg. 123.

(2) Vide supra, pg. 126.

(3) Vide supra, pg. 143.

(4) Vide supra, pg. 148. 
Muchas son las naciones americanas, en las cuales los hombres tienen un espíritu guardián, generalmente un animal, del cual conservan la piel u otra reliquia, como un irreemplazable amuleto al que honran $\mathbf{y}$ sacrifican (1).

No es necesaria mucha perspicacia para apercibirse de la individualidad de estos talismanes, la que, por ser tan grande, hace que estén muy cerca de ser fetiches; lo cual es aún más evidente si se quiere, en las imágenes desus manitus, que llevan sobre sí los algonquines.

Mas, si la mayor parte y los más importantes amuletos, hechos de reliquias de animales, tienen este origen, hay ótros que son independientes del espíritu guardián y cuya función es asegurar abundante cacería (2). Estos están basados ordinariamente, en lo que Frazer llama mágica por contagio, mas no por esto son menos individuales, ya que si tienen virtud, es porque se considera residente en ellos parte del espíritu del animal a que pertenecen y mediante el cual ejercen su acción.

(1) Vide supra, pgs. 130 y sig.

2) Vide Supra, pg. 114 y sig. 
Palmaria prueba de la individualidad de los amuletos del Nuevo Mundo es también el culto que les rinden sus dueños, ya que éste sería incomprensible si no los considerasen dotados de vida. La existencia de este culto es bien manifiesta, ya que se traduce por actos tan inconfundibles como los sacrificios (1).

Mas, antes de seguir adelante, es indispensable precisar de qué clase de individualidad renimos hablando.

De los ejemplos que hemos aducido, habrá podido el lector ver que, al decir que los amuletos americanos están dotados de individualidad, entendemos afirmar que su poder es particular y propio de cada uno de ellos y que es él que los señala, da a conocer e identifica, entendiendo así, oponer esta noción a la de colectividad, y afirmar que su poder es inherente en cada uno de ellos, no común a todo un género, tipo o categoría; o más claramente, aunque con menos precisión, que están dotados de vida propia y no son fórmulas o símbolos, que se pueden repetir al infinito.

Mas, entendámos bien y precisemos nues. tros conceptos, pues no pensamos que en los

1) Vide supra, pg. 130. 


\section{Religión del Imperio de los Indas}

talismanes americanos reside un espíritu personal; lejos estamos de ello! Conocidas son nuestras ideas acerca de la expresión huaca, que pretendemos haber demostrado que corresponde a una concepción semejante a la de de mana melanesia, wakonda dakota etc. etc. Esta misma concepción es, a nuestro entender la base de los amuletos americanos, ya que, por todos los datos que hemos juntado en la reseña antecende, nos parece que la indiridualidad de éstos proviene de que cada uno de ellos por sí, está dotado de la fuerza mágicoreligiosa, productora de energía y de cuanto es extraordinario, que obra de modo sobrenatural y que está dotada de inteligencia y voluntad (1). Que esta fuerza, si bien esencialmente impersonal, una sola, es divisible sin mengua de su potencial, y que en cuanto está inmanente en cada uno de estos objetos, los constituye en su sér propio, formando así un individuo organizado, en el cual el principio de vida, digámos̀lo así, más propiamente, el de energía está constituído por el mana, siendo el cuerpo el objeto material, en el cual está inmanente $y$ del que es inseparable esta fuerza organizada, consciente y rolitiva.

1) Vide supra, pg. 70. 
Los conceptos que ramos emitiendo tienen perfecta y cabal aplicación en los conopas peruanos. En efecto, su individualidad es bien clara, como lo prueban suficientemente los ritos con que se consultaba en la Sierra a los cunchur (1), a los cuales se dirigían como a padres (2), y a los que, digámoslo así, personalmente ofrecían sacrificios (3), así como las ofrendas que les hacían las mujeres embarazadas (4), el cuidado que tenían de transmitírselos de padres a hijos o, a falta de éstos, al pariente por afinidad más cercano, al amigo más querido, o de juntarlos con el antepasado fundador del ayllu (5); y, en fin, por la manera de adquirirlos, tratando de adivinar si eran o no, por su esencia, amuletos (6).

Además, merced a Avila, sabemos que estos amuletos tenían, fuera de su nombre general, cada uno el suyo propio (7).

(1) Vide supra, pg. 107.

(2) Id. id., pg: 108.

(3) Loc cit.

(4) Id. id., pg. 103.

(5) Vide supra, pg. 105.

(6) Id. id., pg. 106.

(7) Avila, Relación de la Idolatría de los Indios de este Arzobispado de los Reyes. 
Para demostrar que el fundamento de los conopas es el concepto de mana, será snficiente recordar que el distintivo de los conopas, su característica más constante era el de ser piedras u otras cosas raras o, por algún concepto inexplicables; lo cual, según lo hemos manifestado anteriormente, era lo que hacía que una cosa fuese tenida por huaca ya que a cuanto es extraño $\theta$ incomprensible se creía dotado de poder mágico religioso (1).

El amuleto, en este estado de su evolución, presenta muchos puntos de contacto y casi se confunde con el fetiche, y quizás no sea temerario el suponer que, desarrollándose las religiones y precisándose el concepto de divino, el talismán individual desdóblase en el amuleto genérico $\mathrm{y}$ en el fetiche, ya que, en su estado individual, el amuleto se diferencia del fetiche, por ser este último morada perpetua o momentánea de un dios o de un espíritu (2); lo que supone una diferencia esencial entre el espíritu y. su receptáculo, lo que no acontece en el amuleto, en el que la fuerza mágica está unida esencialmente a la forma.

(1) Id. id., pg. 86.

(2) Vide supra, pg. 112. 
Es verdad que siempre es penoso hablar de fetiches, palabra que, etimológicamente, sólo significa facticio (1), que es una de las expresiones técnicas de que más se ha abusado, usándola arbitrariamente, apenas hay fenómeno religioso distinto del monoteísmo, que no haya recibido alguna vez el calificativo de fetichismo. Mas, si limitamos este concepto; como lo hemos hecho anteriormente, y tenemos en cuenta que lo más característico de esta forma de religión es que el espíritu, que habita en el objeto, puede entrar o salir de él, a su voluntad, y obligársele a volver a su morada, practicando ceremonias adecuadas; $y$ que al fetiche se le puede abandonar cuando ya no se lo juzga necesario (2), no cabe duda de que los conopas y objetos semejantes de América no son fetiches aunque tengan tantos puntos de contacto con éstos, que Lewis Spence puede decir, con cierto semblante de razón, que los amuletos mexicanos como casi todos

(1) Aston, Fetichism in Hantings Encyclopaedia of Ethics and Religion, Vol. V, pg. 894, Edimbourgh, 1912.

(2) Toy, Introduction to the History of Religion. Boston 1913, pg. 100. 
los del Nuevo Mando eran fetiches personales (1).

Más exacto es afirmar que la individualidad de los amnletos, que no es exclusiva de los americanos sino propia de todos los pueblos que se encuentran en el mismo nivel de evolución religiosa, representa un estado primitivo, en el cual no está aún bien diferenciado el amuleto del fetiche; aplicándose en esto, como en todo fenómeno orgánico, la gran ley del progreso, la división del trabajo.

Uno de los distintivos más propios del amuleto es su carácter privado (2), y éste es bien manifiesto en los conopas, de los cuales, si los súbditos de los Incas esperaban protección y ayuda en general, confiaban sobre todo, en que les darían alimento abundante.

La alimentación es el primer problema del primitivo, al cual se le presenta, no bajo la forma amplia y elástica de riqueza, como en las sociedades más avanzadas, en las que existe la moneda, sino de una manera mucho más angustiosa y apremiante, la obtención de sustancias alimenticias. Este es el eje, alrededor

(1) Lewis Spence, Charms and Amulets in Mexico Hastings Encyclopaedia of Ethics and Religion, Vol. III, pg. 455.

(2) Vide supra, pg. 111. 
del cual giran en las razas primitivas, no sólo el mundo físico, sino el suprasensible y religioso.

Así, por la enumeración hecha en este capítulo, habrá podido ver el lector que, entre los pueblos cazadores, el amuleto está destinado a proveer do abundantes presas, entre los agrícolas, de buenas cosechas: éstos son fenómenos demasiado conocidos de los estudiosos, para que sea útil insistir en ellos; pero séanos lícito recordar cuán grande es la influencia del medio económico sobre el mundo religioso, puesto que el solo estudio de los amuletos sería suficiente para darnos a conocer los medios de subsistencia de los diferentes pueblos americanos. 


$$
\text { - }
$$




\section{CAPITULO III}

\section{APACHITAS}

Todos aquellos que han escrito, desde la Oonquista hasta nuestros días, descripciones o relaciones del Perú o de los países vecinos, que formaron parte del Imperio Incaico, han hablado de los apachitas o montones de piedra, situados en los pasos de las cordilleras, en las encrucijadas $y$ en otros lugares de los caminos, en los cuales los viajeros indígenas nunca dejan de añadir una nueva piedra.

Las más extravagantes teorías, las más falsas hipótesis han sido emitidas para explicar esta costumbre, que, aunque de origen idolátrico, no fue perseguida con rigor aun en Jas épocas en que se tuvo mayor empeño en cristianizar a los indios y cuando se castigaba con gran severidad el delito de idolatría. Verdad es que el Concilio Provincial celebrado en Lima en 1567, condena esta práctica como sapersticiosa, si bien autorizo su tolerancia fa- 


\section{ReLigión DeL IMPerio de LOS INOAS}

cultando a los curas para poner si les parecía decente, una cruz en la apachita que así quedaba cristianizada (1).

La práctica de depositar los caminantes una piedra, un palo u otra cosa parecida $y$ de escaso valor en sitios determinados no es exclusira del antiguo Perú, ya que igual costumbre ha existido en los más diversos países, tan to del Viejo como del Nuevo Mundo, y es una de aquellas usanzas primitivas, en que todas las razas y pueblos coinciden.

Así, muchos son los escritores, que han tratado de encontrar las razones, que han determinado la erección de esta clase de informes monumentos, cuyo autor es un pueblo y cuya construcción nunca se acaba.

Ninguna pretensión tenemos de conocer todas estas teorías; pero, antes de examinar los apachitas peruanos $y$ de indagar su origen, nos parece conveniente resumir algunas de las interpretaciones propuestas notables ya por sus autores, ya por su valor intrínseco.

(1) Que los adoratorios de los caminos que los Indios llaman Apachitas procuren los Sacerdotes cada uno su distrito quitarlos y deshacerlos del todo, y en esto se les pone precepto, y si les pareciere cosa decente' pongan una cruz en su lugar. Sumario del concilio provincial que se celebró en la Ciudad de los Reyes el año de 1567. Serilla, 1641, No: 100, pg. 64. 
Curioso es, sin duda, el recordar la opinión de Carlos Darwin, autor de muchas y fecundas hipótesis, que tánto han contribuido al progreso de las ciencias naturales.

Al hablar de los carines que encontró en los pasos de. la Sierra de Animas, on el Uruguay, emite la opinión de que el origen de estos monumentos tan comunes es el deseo de conmemorar un acontecimiento en el punto más alto de los vecinos a aquel en que aconteció, lo cual cree es debido a una tendencia común a todos los hombres (1).

Esta interpretación tan poco científica, sólo merece recordarse por haber sido emitida por uno de los hombres que más han influído en la intelectualidad moderna.

Mayor importancia tiene la teoría emitida por el helenista Welcker, ai tratar del culto de Hermes, y que aun, en nuestros días, ha sido adoptada por un mitólogo eminente, Farnell. Según los autores mencionados, estos montones eran señales para los caminantes, anteriores a la construcción de rutas definidas, que, por servir para un fin útil a toda la comunidad, cayeron bajo un tabu religioso,

(1) Darwin (Charls), Journal of rescarches in to the Geology and Natural History, London, 1840, pg. 52. 


\section{Religión del Imperio de los Indas}

al ser consagrados al dios de los caminos, llegando así los carines cuya naturaleza primitiva no era religiosa, a ser objetos de adoración y a estar cargados de poder divino, de tal modo que los viajeros depositaban ofrendas en ellos, en acción de gracias, las cuales (ofrendas) eran de la misma naturaleza que el montón y por cuyo intermedio se trataba de establecer cierta alianza y comunión entre el dios y el viajero.

Andree, que estudió detenidamente el asunto, opina que «son estos los monumentos más primitivos $y$ antiguos y que están destinados a recordar toda clase de acontecimientos, así los prósperos como los adversos. Pero este uso no conmemora solamente hechos, sino también personas, y por esto, las tumbas son adornadas con montones de piedras, caracterizados, por ser hechos con ofrendas de diferentes personas $y$ en divorsos tiempos; y aun pueden ser considerados como recuerdos de reconocimiento los elevados por viajeros, al regreso de expediciones peligrosas, sea en las costas, sea on lo alto de las montañas, en acción de

(1) Famell, Cults of the Greek States, Oxfor, 1896, Vol. V, pg. 18 . 
gracias a la dirinidad local $y$ para probar a los que sigan sus pisadas que la penosa ruta les ha sido suavizada. En sí mismos, estos montones son ofrendas, a decir rerdad, las menos costosas, las más simples y cómudas » (1).

Según Hartland, la costumbre de erigir montones de piedras, que es tan antigua como esparcida por el mundo, debe explicarse, distinguiendo tres clases de montones.

I. Los carines, a los cuales no se hacen añadiduras $y$ en los que no se celebra ningún rito. Estos no existen sino en los lugares, donde se ha olvidado el motiro de su erección.

II. Aquellos que se levantan sobre el lugar, en el cual un hombre ha muerto, especialmente, si ha parecido de modo riolento.

III. Los de los carines eregidos en lugares sagrados.

Estas dos últimas clases son, prácticamente, equivalentes, fa que, en todo el mundo, las tumbas, sobre todo, las de aquellos que perecían violentamente, han sido tenidas por sagradas. Así, en la segunda y tercera clase de carines el arrojar piedras tiene por objeto escho.

(1) Andree (R.), Ethnographische Parallelen and Verglei- 
tablecer una unión ceremonial con el espíritu, que se supone reside en el carín (4).

Leibrecht que ha estudiado prolijamento la costumbre que aquí nos interesa, no ha formulado una explicación clara de su origen. Este autor en su erudito estudio, examina primeramente los carines que se erigen sobre lugares de enterramiento, estudia luego aquellos que se encuentran en sitios sagrados, en que se cree reside una divinidad, para considerar después aquellos en que el arrojar nuevas piedras al montón, se hacen en señal de menosprecio al genio del lugar o al espíritu del muerto allí enterrado. Parece que la opinión de este autor es, que el origen de esta costumbre es el deseo de perpetuar la memoria de aquel que bajo el montón se halla enterrado, y que las piedras que se añaden al carin, son ofrendas destinadas al alma del muerto; con el transcurso del tiempo olvídase el origen del montículo y para explicar su existencia fórjanso nuevas lejendas, on las que se cuenta que allí existe nu dios al que se debe honrar, o un

(4) Hartland (E. S.), The Legend of Perseus, Vol. II pgs. 204 a 209, 211 y 218, London, 1895. 
espíritu maligno al que es preciso menospreciar (1).

Dussaud se propone explicar las piedras que se arrojan en montones determinados, suponiendo que son oraciones materializadas, incorporadas en la piedra, para que, forzosamente, lleguen al dios o genio del lugar residente en el sitio en que se erige el montón (2). Esta singular teoría parece tanto más extraordinaria, cuanto que ha sido formulada, con posterioridad a la publicación del Ramo de Oro, en donde Frazer sostiene la primera explicación probable de esta frecuentísima costumbre, explicación que ha sido ordinariamente aceptada.

Este autor, fundándose en el proceso bien conocido, y del cual no faltarán ejemplos en este estudio, de encarnar un mal físico o moral en un objeto inanimado, para así, poder arrojarlo y libertarse de él, y apoyándose en numerosos hechos, sostiene que el acto de depositar piedras en lugares señalados tiene por objeto li-

(1) Leibrecht (Felix), Zur Volkskunde. Alte and Teue Aufsätze. Heilbronn 1879, pgs. 267 a 284., especialmente pgs. 267 y 276.

(2) Dussaud (R.), La materialisation de la priere en Orient Bulletin et Memoirs de la Societé d'Antropology, V Serie, Vol. VII, Paris, 1906, pgs. 213-220. 
bertarse de la fatiga, de la enfermedad, del miedo, del horror, transferidos a la piedra o rama que se depositan en el montón (1).

Casi idéntica es la explicación propuesta por Dontte, que cree, como el sabio autor del Ramo de Oro, que el origen de estos montones es explicable por el deseo de expulsar, por medio de la piedra que en ellos se deposita, el cansancio en las cuestas, la indecisión en las encrucijadas de los caminos $y$ las influencias nocivas de las sepulturas de aquellos que mueren de modo violento. Si bien opina que este motivo original se modifica con el transcurso del tiempo, ya que los carines llegan a ser tenidos por beneficios, puesto que libertan del mal, de donde se origina la mezcla de temor y reverencia, de que son objeto (2).

Más reservado se muestra Dudley Kidd, quien juzga que son muchas las causas que han originado esta costumbre; así, afirma que, en ciertos casos, está fundada en magia imitativa, para detener el curso del día, ya que muchas tribus indican las horas, colocando ra-

(1) Frazer, The Golden Bough. Vol. IX, The Scapegoat. pg. 22, nota 2a. London, 1914.

(2) Doutte (Edmond), Magie et Religion dans l'Afrique du Nord, Alger, 1909, pgs. 427 a 435. 
mas en los árboles. Cree también que puede originarse de la creencia que, en el lugar donde se erige el montón, moran malos espíritus o almas airadas, $y$ siendo entonces ofrendas las piedras que en él se ponen. Opina, asímismo, que, en algunas circunstancias, su fin es defenderse de un espíritu enemigo; mas juzga que, en la mayor parte de los casos, esta práctica está basada en la expulsión de un mal, incorporándolo en una materia determinada (1).

De todas estas diver'sas teorías, ninguna hay que nos satisfaga enteramente, ya que o no se hacen cargo de la verdadera naturaleza o del rito o sólo se aplican a un limitado número de hechos. Así, para explicar los apachitas peruanos seguiremos el mismo método que en los capítulos anteriores, buscando el fundamento de la costumbre, no en un solo pueblo, sino en todos aquellos en que conocemos usanzas análogas; para lo cual, comenzaremos por enumerar algunos casos, que ninguna de las hipótesis anterioros explica y que, al parecer, están fundados en la idea verdaderamente sencilla $\mathrm{y}$ primitiva de impedir la

(1) Dudley Kidd, The essencial Kafir, London, 1914. 
emanación de una fuerza mágica, cuyos efectos se temen, tapando, como si dijéramos, su manantial: concepción simplicísima muy en armonía con las ideas de los primitiros acerca de la virtud mágica, de las que ya nos hemos ocupado, $\boldsymbol{y}$ tal como la que podíamos esperar sirviese de base a una práctica difundida en todo el orbe $y$ entre los pueblos más heterogéneos.

Refieren Spencer y Gillen que, en Australia, no lejos de Undulia, doce millas al Este de Alice Springs, hay unos montones de piedras, acerca de los cuales cuentan que, en ese lngar, en los tiempos mitológicos, vivían dos hombres del tótem del águila hank; que un día comieron a muchas gentes de su clan, lo cual prodájoles tan fuerte indigestión, que les causó abundante rómito, el cual está representado por los carines, llamados ulkutha. Creen los aborígenes que estas piedras están repletas de poder mágico maligno $y$ a fin de impedir lo emanen, es preciso cubrirlas, para que no se las rea, ya que, si alguien las mirase, contraería un fuertísimo vómito. Así, todo indígena, de cualquier sexo o edad, al pasar por el sitio, arroja en el montón un palito, para, 
de este modo ayudar a cubrir el poder mágico e impedir su salida.

Oreen también los australianos que uno de los antecesores de los del tótem Muntilier’u (nombre de una pequeña rata), en la tribu Urabuna, yendo de viaje, trató de tener conocimiento con mujeres que aún no habían pasado por los ritos de iniciación; en castigo de lo cual se le cayó el órgano masculino, muriendo juntamente con las mujeres. Esto aconteció en un lugar llamado Atnintjunera, que está señalado por dos piedras, y repleto de poder mágico nocivo, tan poderoso, que sólo los viejos pueden pasar por las inmediaciones, sin morir al instante. De tiempo en tiempo, va a este sitio un anciano $y$ arroja piedras $y$ ramas, para tener tapado el poder mágico (1).

Los Baganda tenían especial horror a los suicidas, los cuales eran más frecuentemente hombres que mujeres, siendo el medio ordinario de suicidio el ahorcarse de un árbol.

Cnando algún desgraciado atentaba contra su vida, el árbol de que se había colgado era cortado, para que sirviese de leña para quemar

(1) Spencer and Gillen, The Northern Tribes of Central Australia, London, 1904, pg. 472. 
el cuerpo del difunto, lo cual se hacía en donde se cruzaban dos caminos. Si el crimen se babía verificado en la casa, destruíanla y sus materiales servían para la cremación del cadáver. Sobre el sitio, donde había ardido la pira y en el cual reposaban los restos del suicida, no tardaba en levantarse un montículo, ya que cuantas mujeres pasaban por junto a él arrojaban hierbas o palos en el montón, para impedir que el alma del difunto, penetrando en ellas, renaciera: costumbre que no sólo observaban las mujeres, pues todos temían que el espíriu, apoderándose del pasante, le hiciese cometer ignal delito (1).

A los niños que nacían de pie, mataban y enterraban en las encrucijadas de los caminos, $\boldsymbol{y}$, sobre sus tumbas, se levantaban montones a reces considerables; pnes todas las mujeres, al pasar, arrojaban algo sobre su tumba, para que no saliese y se apoderase de ellas el espíritu que allí residía.

Igual cosa acontecía en las sepulturas de los gemelos, junto a las cuales nadie quería pasar (2), 289.

(1) Roscoe, The Baganda, London, 1911, pgs. 21, 127 y

(2) Id. id., pgs. 47, 124 y 127. 
Semejantes montones reíanse también en las tumbas de los blancos, muertos en el país (1).

Ouando alguien era acusado de brujería y después de la prueba del veneno, reconocido culpable; lo quemaban en un campo baldío, y los que por él pasaban arrojaban sobre las cenizas, hierbas y palos, para impedir que el espíritu los cogiese (2).

En Islandia los carines en los que los transenntes depositan al pasar, piedras, o a falta de éstas un zapato, un guante, una liga, una rama o una moneda, llámanse dys que signiÎca tumba cubierta con piedras, si bien a este nombre añaden a veces el calificativo greide que equivale a ofrenda. Mas esta ofrenda es propiamente una precaución contra el alma del que está allí sepultado, el cual es en muchos casos algún hombre que pereció de un modo violento, cuyo espíritu es tenido por malévolo del que es preciso defenderse arrojando una nueva piedra en el carin (3).

En Suecia cuando en un camino perecía

(1) Roscoe, The Baganda, London, 1911, pg. 289.

(2) Id. pgs. 289 y 290.

(3) Leibrecht, Zur Volkeskunde Heilbronn, 1879, pg. 237 y 274 . 
alguien de un modo violento, sea asesinado o de otra manera, y se teme que aparezca $y$ perturbe a los viajeros, ya en forma de un espíritu o en la de fantasma, los pasantes depositaban en el lugar del siniestro una piedra, una rama o una moneda. Muy peligroso sería dejar de arrojar una piedra sobre la tumba de un suicida al pasar junto a ella, pues quien tal imprudencia cometiere caería bajo el maligno influjo del perverso espíritu, de aquel que atentó contra sus días.

No sólo arrojan piedras en Suecia en estos sitios, sino en los lugaras en que ha habido un comercio ilícito o cualquier otro acto impuro (1).

En Grecia es usauza popular, arrojar piedras en las tumbas de las personalidades notables de mala reputación, exclamando: Maldito sea! Así se forman montículos sobre los que cada pasajero arroja nuevas piedras, ignorando en muchos casos el por qué de la costumbre. Parece que el fin de este uso es impedir que el muerto moleste a los vivos, con apariciones; pues bien conocido es cuan arraigado está entre

(1) Leibrecht, Op. cit., pg. 274 y 275. 
los griegos el temor al vampiro salido de las tumbas (1).

El carin de Vicar, en el condado de irlandes de Armagh, es un montón de piedras, rodeado de un círculo de piedras entre las cuales hay una que tiene caracteres oghánicos, una avertura permite la entrada al interior del montículo. Nadie pasa sin coger una piedra y dejarla en el montículo, pero desgraciado aquel que cogiera una sola piedra del carin pues le sobrevendría una gran desgracia (2).

Los Bosquimanos creen que el domonio está enterrado bajo los carines, $y$ todos, al pasar, arrojan allí una piedra, para que Satán no pueda salir (3).

En el Chota Nagpur, especialmente, en los estados aborígenes, se encuentran, a menudo, montones de hojas, ramas o piedras, que ban sido arrojadas por los pasajeros en los lugares, en que se supone que alguien ha sido muerto por una bestia feroz. Ia creencia es que aquel que no observa esta usanza, bien pronto ve surgir ante sí un animal de la especie de aquel que causó la desgracia que

(1) Leibrecht, Op. cit., pg. 282.

(2) Leibrecht, Op. cit., pg. 280.

(3) Andree, Ethographische Parallelen und Vergleicg. 
conmemora el hacinamiento (1). Lo cual indica muy bien que se juzga que allí existe una virtud nocira, en forma de carnívoro, a la que se impide salir, echando una hoja, rama o piedra al montón.

En Mirzpur, los carines, erigidos con igual motivo, están al cuidado de un Baiga o sacerdote indígena, que sacrifica en ellos un cerdo, un gallo, o un poco de licor; en ciertas ocasiones, enciende junto a los montones, una lamparita (2).

En Schwannewitg pueblo perteneciente a Dahleu cerca de Oschatg, $y$ que se llama así por un dios que allí se reneraba, en un bosque sagrado; has un pantano llamado el lago de la muerte, en donde sacrificaban en tiempo del paganismo, vírgenes cujos espíritus aun vagan en la vecindad, por esto y para defenderse de estas apariciones, cada transeunte pone una rama en el lugar del sacrificio. En los caminos de Alemania, haíba antiguamente en los lngares en que yacía el cadáver de algún, muerto violentamente montones, de

(1) Journal of the Aciatic Society of Bengal, No. 21913, pg. 87, Supplement. Calcutta 1903.

(2) Frazer, The Golden Bougg, Vol. XI, (The Scapegoat), London, 1914, pg. 27. 
piedras o palos a los que todo transennte añadía algo, a esta clase de montículos pertenecía el situado sobre la tumba de un tabernero que fue asesinado de un modo misterioso en los alrededores la aldea de Rauen cerca de Storkow (1).

En los Alpes en el camino de Burgeis pueblo en el Vintschgan hay un lngar consagrado a la "Virgen salraje», en donde existe un montón de piedras, los niños que por vez primera suben al cerro deben tomar una piedra, escupir en ella y arrojarla al montón, diciendo: ofrezco a la Virgen Salvaje, costumbre que deben observar también los adultos, pues de lo contrario se expondrían a un gravísimo peligro (2).

En Africa Mungo Park hay un árbol, delante del cual, según sus guías, no era posible pasar, sin ofrecerle un trapo, a menos de exponerse a su cólera (3).

En el pueblo de N'pâl, situado entre el país de Caydor y el de Oualo, hay una piedra, a la cual, según uso antiquísimo, todos, al pasar, ofrecen un hilo de su vestidura. Esta piedra es tenida por guardián del pueblo, al cual

(1) Leibrech, Zur Volkskunde Heilbronn, 1879, pg. 272.

(2) Id. id., pg. 268.

3) Reville, Histoire des Religions, Vol. I, pg. 62. 
estiman por may seguro, ya que dicen que, cuando está en peligro, da la piedra vueltas al rededor de él y lo defiende por medio de su poder sobrenatural (1).

Los peregrinos a la Meca, en el $10^{\circ}$. día del mes de Dzon'-l' hiddja, después de haber hecho la oración de la mañana y antes de la salida del sol, se dirigen a Mida. En el camino deben recitar ciertas oraciones $y$ atravesar, corriendo, una llanura. Al llegar al estrecho valle de Mida, principian a arrojar piedras, del tamaño de un fréjol, tomadas, preferentemente, en un lugar determinado; pero que pueden cogerse en cualquiera otra parte, mas sin tomar nunca nna piedra que haya sido ya arrojada en los carines. Antes de servirse do ellas, lávanlas.

Al tirar las piedras, dicen la siguiente oración: «En el nombre de Dios, Dios es grande a pesar del demonio y los suyos: haced, Señor que los trabajos de mi peregrinaje sean dignos de Tí y agradables a tus ojos. Concededme el perdón de mis pecados e iniquidades»; 0 bien: «En el nombre de Dios, Dios sólo es

(1) Caille (Reue), Journal d'un royage a Temboctou et a Jenné. Paris, 1830, Vol. I, pg. 25. 
grande. Arrojamos estas piedras, para estar seguros de los ataques del demonio y de sus legiones".

Las siete primeras piedras las arrojan contra un pilar o altar de piedra sin tallar, que está a la entrada del valle; las otras siete contra otro pilar, que está por la mitad del valle, y las otras siete a la extremidad occidental, junto a un muro de piedra.

En los tres días siguientes, los peregrinos atraviesan de nuevo el valle de Mida, repitiendo las ceremonias que hicieron, al pasarlo por primera vez.

El último día, cámbianse de vestido y entran a la Oaba, con lo cual dan tórmino al peregrinaje.

La peregrinación a la Meca, que los Mahometanos estiman por muy meritoria, pertenece, a no dudarlo, a la Religión Islámica; mas el arrojar las piedras en el valle de Mida, así como otras de las ceremonias que se practican en los días que dura el peregrinaje, son anteriores al Islamismo; $y$, según algunos autores árabes, antes de Mahoma, las piedras eran mayores, y sólo las arrojaban en los montones a la caída de la tarde y cuando el Oficial, enReligión del Imperio de los Incas 
cargado de presidir el rito, había consentido principiase.

La costumbre de que venimos tratando no ha dejado de interesar a los teólogos árabes, quienes han propuesto rarias explicaciones, que poco o ningún interés tienen para nosotros (1).

La idea general, la tradición es que esta práctica originóse de que Abraham, por consejo del Arcángel Gabriel, apedreó al demonio, que quiso impedirle pasase por Mida y que se dejó ver en los tres lugares, donde ahora los peregrinos acumulan guijar'os.

Hay quien dice que las piedras deben arrojarse por la espalda, para renunciar solemnemente al demonio (2).

Muy significativos para nuestro estudio son estos usos de un pueblo de cultura ya muy desarrollada; pues en ellos se nota muy claramente que el fin de acumular piedras en un lugar determinado es el mismo en pueblos tan distintos por el grado de su evolución religiosa, como los Australianos y los Arabes.

(1) Algunas de las explicaciones musulmanas de esta costumbre pueden verse en Leibrecht, Zur Volkskunde, pg. 280 $y$ sig.

(2) Chauvin, (V.), Le Jet des piedres au pelerinage de la Jieeque, Anvers, 1902. pgs. $272-278$ y 284. 
En efecto, tanto la oración que acompaña al acto de tirar las piedras, como la leyenda que explica el origen del rito, evidencian que el fin de éste es apedrear, cubrir al demonio (forma evolncionada de la fuerza mágica nociva), para estar a seguro de sus ataques.

De igual manera piensan los Kayancs de Borneo, que creen pueden ahuyentar a los ma. los espíritus, arrojándoles piedras o palos, lo cual no dejan de hacer, cuando pasan junto a un sitio, en donde creen reside un demonio (1).

A estas costumbres se asemeja la curiosa práctica que se observaba en algunos lugares de Alemania, de apedrear los lugares en que existió un monumento religioso pagano, siempre que se pasaba junto a ellos, en señal del triunfo del cristianismo sobre los falsos dioses (2).

Ya tendremos ocasión de ocuparnos de los carines del Tibet; mas, antes de pasar adelante, conviene recordar lo observado en este país por Waddell. Cuenta este autor que la parte más alta de los pasos, entre la India y el Tibet, está marcada por una línea de carines y

(1) Frazer, The Golden Bough, Vol. IX (The Scapegoat). London, 1914, pg. 18.

(2) Leibrech, Zur Volkskunde Heilbronn, 1879, pg. 280, 
que los guías y arrieros tibeteños, que con él iban, se detavieron ante éstos y, diriguiéndose hacia Ohnmolhario, montaña de la diosa señora, reverentemente, pusieron una piedra en el carín, exclamando, con voz viril: «Tomad, tomad esta ofrenda a los dioses. Los dioses han conquistado. Los demonios son desterrados!» (1).

Muy poco avenible con las teorías que hemos analizado $\mathrm{y}$ en perfecto acuerdo con la hipótesis de que, bajo los montones, existe un poder mágico nocivo, cuya emanación se trata de evitar, es la siguiente historia, narrada por Jansen. Onenta este verídico autor, que un árabe, que caminaba por el desierto, al ver uno de aquellos montones que se levantan en los lugares, donde se ha cometido un asesinato, se persuadió de que ese montón (ragín) le quería matar y turo tal terror, que temblaba de pies a cabeza. Por la Vida de Alaha, exclamó, conjurándole, no me matéis ni hagáis mal; y, apenas pasó junto al carín, echó a correr con todas sus fuerzas, para ponerse al abrigo de sus golpes (2). 117.

(1) Waddell, Llasa and its misteries, London, 1905, pg.

(2) Jansen, Costumes des Arabes du Pays de Moab, Paris, 1903 , pg. 337. 
Quizás la misma idea fundamental de cubrir el lugar, de donde se emana la influencia nociva, es el origen de la siguiente costumbre lilloet. En el territorio ocupado por estos indios, hay un monte llamado Po'pesamen (corazoncito). Ouantos cazadores acampan en su vecindad, visitan la cumbre, a la cual se dirigen, diciendo: «Oh Jefe, que no llueva ni nieble; dadnos un fácil cabe de raíces y prospera cacería. Tomad todo el olor para tí, a fin de que la caza no nos vea ». Tras lo cual tanto los hombres como las mujeres se golpean las piernas con juncos, que han llevado para el efecto, y que depositan luégo en un montón (1).

Esta práctica nos parece explicable, suponiendo que los Lilloetes creen, como tantos otros pueblos, que el monte al sentirse hollado, manifiesta su enojo haciendo llover; para impedir lo cual, se apresuran a tapar el sitio, por donde emana el monte su wakonda, cansa de la lluvia.

En la más alta punta de la colina que domina Weston-super-Marc, los pescadores en su viaje diario a Sand Bay, colocan una nue-

(1) Teit, The Lilloet indians. Jesup North Pacific Expodition, Vol. II, New York, 1906, pg. 279. 
va piedra en el carín que hay en ese lugar, para tener feliz pesca, quizás con el objeto de impedir la emanación de una fuerza o influencia favorable a los peces (1).

En la culta Grecia, el dios Hermes protegía las encrucijadas de los caminos, y relacionados con él eran los carines que había, donde dos rutas se encontraban, y en los cuales todo viajero depositaba una piedra. Las encrucijadas eran tenidas por lugares peligrosos, a causa de malos espíritus que las infestaban (2).

En los alrededores de un pueblo de la isla Samoa, había una piedra en el camino que conduce a las plantaciones, a la cual todos los que iban o venían de sus sembríos besaban o, mejor dicho, olían, crejendo morir si tal no hiciesen. Acerca de esta piedra contaban que, habiendo dos hermanos apostado a cuál era más valeroso, uno de ellos que era cobarde, volvió las espaldas, quedando convertido, por

(1) Leibrecht, Zur Volkskunde Heilbronn, 1879, pg. 279.

(2) Farnell, The cults of the Greek, States, Vol. V, pgs. 1-18, Oxford, 1896. - Paris, (P.), Hermes in Deremberg et Saglio. Diccioniare des Antiquités Greques et Romaines, Vol. III, pg. 130, París, 1900. 
esto, en piedra, en cumplimiento de lo que habían apostatado (1).

En la misma isla, llaman Fonge y Toafa a dos rocas planas, que estaban sobre un hacinamiento de piedras sueltas y que eran tenidas por los padres de Loato; dios de la lluvia. Todo aquel que, por casualidad, pasaba junto a ellas y lleraba comida, deteníase para ofrecerles un poco de alimento (2).

Los Bawenda, miembros de la numerosa raza Bantu, autes de atravesar el río Motsêndute, cerca de Pipits, en donde, según sus decires, vive el espíritu de las aguas, arrojan una rama, piedra $\mathbf{a}$ otra cosa de igual valor, para que el espíritu les deje pasar el río con facilidad. (3).

El clan Baganda, Bean dícese descendiente de un héroe, cuya sangre dió origen al río $\mathrm{Na}$ kisa, y adora a los espíritas del río en dos montones de hierba 5 palos que hay a las orillas, a los cuales (montones) se ofrecen cabras y cerveza en sacrificio. Cuando los Bagandas

(1) Turner. Samoa, London, 1884, pg.

(2) Id. id., pg. 25 .

(3) Gotsching, The Bawenda. The Journal of the Royal Antropological Institute of Grat Britain and Ieland, Vol. XXXV, pg. 381, London 1905. 
atraviesan el río, arrojan hierba $y$ palitos en los montones de las dos orillas, para que el espíritu del río les dé libre paso (1).

Los que descienden a los pozos de Tomberg (Colonia) deben, para no caer al bajar, arrojar una piedra (2).

Al pasar frente a la Mina del Enano Wemgarten, los muchachos arrojan piedras, y en el Delfinado, al pasar junto a cierto precipicio, es necesario tirar una piedra al fondo para conciliar al espíritu de la montaña (3).

En los últimos casos que hemos citado, parécenos que nuestra hipótesis es perfectamente aplicable, y que esas usanzas pueden explicarse, suponiéndolas originadas del deseo de impedir la salida del poder nocivo, que se cree existe en dichos lugares.

En Oumberland Sound hay un cabo, llamado Iliquimisarbing (el lugar de sacudir la cabeza), lugar peligroso y en el cual ocurren frecuentes desgracias, por lo resbaloso de la roca. Los Esquimales nunca lo pasan sin sacudir la cabeza y emitir un murmullo (4).

(1) Roscoe. The Baganda, London, 1911, pg. 163.

(2) Leibrech, Zur Volkskunde Helbronn, 1879, pg. 276,

(3) Loco cit.

(4) Boas, The Central Eskims $6^{\text {th }}$ Annual Report of the Bureau of Ethnology 1884-1985, Washington, 1888, pg. 597. 
Buchanan dice que en América del Norte, hilachas de ropa, tabaco, mazorcas de maíz, pieles y aun el cuerpo muerto de un animal se encuentran en los caminos difíciles y peligrosos, en las rocas y en las orillas de los rápidos ríos, como tributos pagados a los espíritus de estos sitios (1).

Aseguran los Tiroleses que el arrojar piedras en la cascada de Kriml pone a los espíritas de este lugar de muy buen humor y libra de toda desgracia en paso tan peligroso (2).

En el Cáncaso hay carines en los lugares peligrosos (3).

En el Tibet, hay en las cumbres y en los pasos carines que llegan a tener hasta treinta pies de alto, hechos por los viajeros, que, al pasar, colocan algunas piedras, cogidas a la subida.

Los Lamas plantan en los montones, palos, a los cuales atan unos pedazos de seda

(1) Buchanan, History of the Maners and costumes of the North America Indians, London, [1824, xit. por Spencer, Descriptive Sociology American Races compileted and Abstraeted by Prof. David Duncan, London, June. 1878, pg. 244.

(2) Frazer, The Golden Bough Vol. IX, (The Scapegoat), pg. 26, London, 1914.

(3) Hartland, (Edwin Sidney), The Legend of Perseus, Vol. VII, pg. 204, London, 1895. 
azul, cubiertos de cierto polvo blanco y que equivalen a una fórmula de urbanidad.

Al pasar por estos montones, los caminantes se arrodillan para orar. Omitir estas ceremenias, traería grandes desgracias (1).

En ciertos ríos de Africa Occidental, en lngares peligrosos, en los cuales los negros creen que reside algún espíritu irritable o mal intencionado, los Ekoi, antes de confiarse a las aguas, amontonan hojas, que, previamente se frotan a la cabeza. Igual cosa hacen sobre un camaleón que han matado, pues dicen que, si tál no hiciesen, el irritado espíritu de la sabandija obtendría del dios de la tierra Obassi Nzi, venganza contra su matador o sus semejantes (2).

En el interior de Madagascar y en la costa betsimisaraka, se encuentran, a menudo, montones de piedras, terrones y ramitas, constantemente agrandados por los viajeros, que arrojan al montón lo que tienen a mano, murmurando un encantamiento u oración. Aseguran los Malgaches que, con oferta tan poco costosa, hecha al espíritu de los caminos, ob-

(1) Cooper, Travels of a Pioneer of Comerce, London, 1871, pgs. 75 y 276.

(2) Frazer, Op, cit., Vol. IX, pg. 28. 
tienen una ruta fácil, segura posada y se li. bertan de los peligros del viaje. Estus montones llámanse ganatovana (1).

Este caso, como los antecedentes, y algunos que vamos a exponer a continuación, nos parece comprensible tan sólo suponiendo que, al arrojar las piedras en el montón, se tapa o cubre la fuente de la emanación de la fuerza mágica maligna, que se manifiesta en los azares del viaje y ocasiona los accidentes,' producidos por los peligros de determina dos lugares o de otro modo cualquiera. Así, en Onomben, encontró el P. Trilles, en la cumbre de un monte, un árbol, cuyo tronco, a modo de horca, forma una especie de plataforma, en la cual, todo pasante deja una rama o unas hojas, formando todos estos depósitos un montón considerable. Todos los naturales, que iban al servicio del Padre, pusieron una rama; mas muchos ignoraban el porqué de la costumbre, que, según uno de ellos, un pahouín, era para que los árboles les fuesen propicios, las raíces no les hiriesen los pies, las ramas no les rom-

(1) Catad (Dr.), Voyage a Madagascar. Le Tour du Monde, Vol. LXV, París, 1888, pg. 40. 
pieran las cabezas y no les aplastaran los tron$\cos (1)$.

Esta costumbre africana nos trae a la memoria la observada en Suiza, en el camino de Lucerna, entre Kulm y Zetzwill, en donde junto a un matorral notable por su vejez, todo viajero coloca una piedra (2).

En el país, en que moran los Zulus, a lo largo de los caminos, se encuentran, a intervalos, carines. Los viajeros, al pasar, se descubren y arrojan una piedra pequeña, diciendo: * Oh carín (uvivane), dadnos fuerza y prosperidad $»$.

En los bosques, los viajeros para tener buen viaje, colocan piedras en las horquillas de los árboles, $\mathrm{y}$, en los lugares cubiertos de pasto, hacen ataditos de hierba (3).

Antiquísima y venerable usanza, que da buena suerte a quien la observa, es, entre los

(1) R. P. Trilles, Mille lieus dans l'inconu. A travers el pays Fang, de la cote aux rives du Bgah Les Missions Catholiques, Lyon, 1902, pg. 142.

(2) Leibrecht, Zur Volkskunde Heilbronn 1879, pg. 270.

(3) Macdonald, Maners, Costumes, Superstitions and Religions ef South Africa Tribes-Journal of the Royal Antropological Institute of Great Britain and Ieland, Vol. XX, pg. 126, London, 1890. 
Zambesis, detenerse ante un árbol y colocar, entre sus ramas, un palito (1).

Según Andree, cuando Roblfs, en su viaje de Trípoli a Ghadames, llegó al límite de Ilammada, los conductores de sus camellos le rogaron que erigiese an montón de piedras, llamado Bu-Sfor o Bussafor; mas no le pudieron explicar el significado ni el fin de este monumento. Fué tan sólo más tarde cuando logró averiguar que los viajeros que, por primera vez, llegan a un lugar importante, deben protegerse contra los maleficios de cierto espíritu, origiendo un Bu-Sfor que, les proteja (2).

En una población del país de Laokon, se añaden piedras a los montones que sirven para determinar las fronteras, siempre que se las traspasa (3).

Iguales carines hay en las fronteras $d \theta$ Galicia española, en donde cada labrador que sale de la provincia en busca de trabajo, pone una piedra, lo que vuelve a hacer cuando regresa a la tierra natal (4).

(1) Dudley Kidd, The essential Kafir, London, 1904.

(2) Andree, (R.), Ethnographische Parallelen und Verglei. che.

(3) Leibrecht, Zur Volkskunde. Heilbronn, 1879, 279.

(4) Id., id. 
Los Basutos, al depositar en los carines una piedra, en la que han escupido, creen asegurarse un feliz viaje (1).

Entre los Zambesis, los montones no son de piedras sino de palos, y estos salvajes llevan siempre palitos para este objeto, con los cuales se frotan, a veces, las piernas antes de arrojarlos. A menudo, colocan piedras en las horquillas de los árboles.

Dicen que es una costumbre muy antigua y que da prosperidad, tal como abundancia de ganado (2).

Los Bannuchis, cuando la mujer es estéril, arrojan 'piedras en los carines que hay sobre las tumbas de aquellos personajes que tienen por santos (3).

En Bechimaland, los que viajan por negocios importantes hacen, por el camino, paquetes de hierba, para tener buena suerte (4).

Entre los tártaros y pequeños rusos se cree que añadir una piedra a los carines, da prós. pero viaje (5).

(1) Dudley Kidd, The Essential Kafir, London, 1904.

(2) Op, cit.

(3) Leibrecht, Zur Volkskunde. Heilbronn, 1879, pg. 269.

(4) Id. id.

(5) Leibrecht, Op cit,, pg. 269. 
Los montañeses de Escocia dicen como cortesía « yo pondré una piedra en tu carín» (1).

En el alto Senegal, a lo largo de los senderos, se encuentran, a menudo, montones de piedras, en los cuales cada viajero deposita úna, para obtener pronto $\mathrm{y}$ feliz regreso (2).

En los pasos, en el altiplano de Mashonaland, se encuentran hacinamientos, formados por los viajeros, que, al pasar, depositan en el montón una piedra o un palo. Los Atonger dicen que éste es un tributo a los espíritus del lugar, para obtener feliz vuelta (3).

Los Oheroquies en sus riajes $\mathrm{y}$ expediciones guerreras, en ciertos lngares, siempre que por allí pasan, ponen una piedra en los montones formados por la constante observancia de esta costumbre. Observar esta usanza asegura feliz viaje (4).

En el distrito del Himalaya, en las cumbres $\mathrm{y}$ encrucijadas, hay carines, $\mathrm{F}$, al hacerles una añadidura los pasantes, ruegan a la

(1) Leibrecht, Loco cito.

(2) Bellany, Notes Ethnographiques recucillies dans l'Haut Senegal Revue d'Ethnographie, Vol. V, Paris, 1886, pg. 83.

(3) Decle (Lionel), Three years in Savage Africa, London, 1898, pg. 288 .

(4) Leibrecht, Zur Volkeskunde Heilbronn, 1879, pg. 279. 
diosa, que suponen reside allí, que les preserve de todo mal (1).

Enfrente de las casas de los Egbos hay frecuentemente un árbol, de hojas verde-oscuras, que los Ekois llaman ucomma.

El Jefe del pueblo Akwa Ibani, viejo ya, contó a Parkinson que, en su jurentud, el árbol que estaba frente a su morada era pequeño; en 1904, el tronco medía 14 pulgadas. Este árbol era reverenciado por los indígenas como nna deidad inferior, $\bar{y}$, en su base, había un carín, en el cual depositaban piedras, aquellos que se habían golpeado contra una de las muchas de que está llená la ruta del pueblo, esperando, así, que este accidente no se repitiese (2).

Si, como ya hemos dicho, los ejemplos anteriores sólo tienen racional explicación en la teoría por nosotros sugerida; más fácil os aún su explicación a las ofertas que los Shuswap, moradores de la Columbia Británica, hacen en determinados lugares. Así, en Whip-

(1) Frazer, She Golden Bough, Vol. IX, (The Scapegoat), pg. 29, London, 1914.

(2. Parkinson (John), A note on the Efik and Ekoi tribes of the Eastern Province of Southern Nigeria Journal of the Royal Anthropological Institute of Great Britain and Ieland, Vol. XXXVII, London, 1904, pg. 264. 
saw Oreek, había un carín, en el camino Similkameen y Hope, al cual todos debían pagar un peaje, poniendo una piedra o rama en el montón (1).

Entre los Jakuts, las cerdas de los caballos han sustituído a las piedras $\mathrm{y}$ a lo largo de los caminos, se ven árboles, recubiertos de cerdas, en los cuales cada caballero añade úna, arrancándola de la cola de su corcel. Estos árboles se encuentran tan sólo en los lugares más elevados de los collados por donde pasan las rutas, y no es sino después de una penosa subida cuando se hace esta ofrenda al espírita del bosque (2).

Si los Estonianos de la isla de Oesel arrojan piedras, gritando Rju, en los carines que hay, en donde ha sido sorprendida en estapro una pareja (3), es probable que sea por un concepto análogo a aquel por el cual los Australianos tapan el Ingar en que pecó y murió el libertino antecesor de los del clan Muntilieru

(1) Dauson (G.), Notes on the Shuswap people of British Columbia Proceedings and trasnsactions of the Royal Society of Canada for the year of 1891, Vol. IX, Montreal, Section II, pg. 38.

(2) Andree, Op. cit.

(3) Andree, Op. cit.

Religion del Imperio de los Incas 
de la tribu de Urabuna (1), esto es, porque, a consecuencia del acto ilícito, se supone poseído el lugar del poder mágico nocivo.

Inexplicable con nuestra hipótesis, como con las expuestas previamente, es la uzansa de los Judíos, que moran en Siria, de hacer una pirámide de piedras en sus sembríos, para protegerlos de los ladrones (2). Lo dicho se debe, quizás, a que estos carines sean distintos de aquellos de que venimos ocupándonos, ya que no se dice que se les haga añadiduras, a no ser que sus constructores se propongan ahuyentar a los ladrones, haciéndoles creer que en su campo existe un poder mágico, a cuya ira se exponen, si traspasan los linderos con intenciones poco honradas (3). Esta hipótesis parece tanto más fundada, cuanto que en los países árabes, se ve a menudo, unos cuantos arados,

(1) Vide supra, pg. 185.

(1) Rouse, Notes from Syria Folk Lore, Vol. VI, London, 1895, pg. 173.

(3) Entre los Akikuyos, bantus del Sur-Este de Africa, a veces, el posesor de un terreno pone un encantamiento en él, para proteger su propiedad e impedir que los extraños gocen de ella. Para indicar que tal ha hecho, coloca ordinariamente paquetes de hojas de banano suspendidas de un árbol o palo. Dundas, The organisation and laws of some Bantu tribes in East Africa-Journal of the Anthropological Institute of Great Britain and Ireland, Vol. XLT, pg. 300, London, 1915. 
amontonados junto a la tumba de un santo. Los campesinos los colocan allí cuando no quieren llevarlos hasta su casa, para estar seguros de que no se los robarán, pues nadie se atrevería a hacer tan grave ofensa al podernso espíritu bajo cuya guarda se eneuentran (1). En la mayor parte de las ocasiones, las tumbas de los personajes sepultados por santos, o son carines o los tienen en sn alrededor.

Es también de dificilísima explicación, la costumbre observada por los campesinos de Dodentiansen, región de Frankember, de depositar al pie de un arbusto situado al borde del bosque, siempre que renían de recoger bellotas en la montaña, unas cuantas de estas frutas, arrojando al mismo tiempo una piedra, costumbre que era preciso observar, so pena de no cosechar bellotas el año entrante o de que si las cosechaban las perdiesen en el camino (2).

Difícil de explicar es, sin duda, la costumbre de los Batokas de Zambeza, quienes mostraron a Livingston un carín que sus antepasados habían erigido, como una protesta contra los males que les había causado una

(1) Johnson, Some Beduin Customs, Man 1918-3-Londres.

(2) Leibrecht, Zur Volkskunde Heilbronn, 1879, pg. 277. 
tribu vecina, en lugar de hacerles la guerra (1). Quizás estos males eran la muerte de algunos de los miembros de la parcialidad y su tumba el carín; en cuyo caso, entraría en el grupo que ramos a examinar a continuación.

En Fiji, algunas tumbas tienen grandes montones de piedras, los que, a reces, sirven para indicar el lugar en que se ha cometido un asesinato (2).

En las islas Sandwich, el rencedor amontona sobre el cuerpo del rencido, pequeñas piedras, que dicen son los trofeos de la victoria (3).

Los aborígenes de la costa norte de la isla Luzon, en las Filipinas, eleran montículos de piedras en memoria de los desaparecidos (4).

Las sombras de los mnertos son mus temidas por los Malgaches, que huyen do la recindad de los sepulcros, a los que sólo se aproximan después de conjurarlos.

Las tumbas aisladas, que están cabe los caminos, son tenidas por infames, 5 los viaje-

(1) Andree, Op. cit.

(2) Williams, Fiji and the Fijans, London, 1858, Vol. I, pg. 192.

(3) Andree, Op. cit.

(4) Id, id. 
ros, al pasar, arrojan sobre ellas una piedra o un puñado de tierra, sin voltearse a mirarlas, a fin de no ser seguidos por los malos genios que allí residen (1).

Los Hotentotes creen en un héroe semidiós, que, según la tradición, murió y renació varias veces y que tiene muchas tumbas on el país, al cual llaman Heitssi Eibib o Hetzi Kabip; y cuando pasan junto a alguna de ellas, arrojan una piedra, para tener buena suerte (2).

Los Namaques entierran a sus muertos sentados, colocándolos en un hueco que excavan con un palo o cuerno, sobre el que amontonan piedras, dejando el instrumento que les ha servido para cavar, clavado en el montón (3).

Fuera de estas tumbas comunes, hay otras, marcadas por un 'carín, ante el cual todos los viajeros se detienen para arrojar una pie-

(1) Finaz S. J., Sépultures de Madagascar. Les Missions Catholiques, Lyon, 1875, Vol. III, pg. 328.

(2) Bleek, Reynard the Fox in South Africa or Hottentot fables and Tales, London, 1864, pg. 76.

Dudley Kidd, The Essential Kafir, London, 1904.

Callaway (Canon), The Religious System of Amazulu Natal, 1868, pg. 67.

(3) Alexander (J. E.), An expedition of discovery of the Interior of Africa, London, 1838, V. I, pg. 170. 


\section{ReLigión DEL IMPERIO De LOS INOAS}

dra o rama, murmurando al mismo tiempo, «dadnos mucho ganado». Dicen que en ellas está enterrado Heiji Eibib, su antecesor, acerca del cual nada saben, sino, que, como ellos, vino del Este $y$ que era rico en gauados (1).

En Amazulu, isivivane, es un montón de piedras, cuyo. significado ignoran los aborígenes, $y$ en el cual los pasantes arrojan una piedra, en la que escupen previamente, diciendo algunas veces: "Buenos días, hijo de Usivivane», personificando así, la voz «isivivane» (2).

El Capitán Harris encontró montones semejantes entre los Matcbele, si bien, dichos negros ignoran su significado (3).

Los Amakara levantan carines sobre las tumbas, a los que hacen constantes añadiduras (4).

Los Maraves, como los Bagandas, queman vivos a los brujos, $y$ en donde se ha verificado la ejecución, al pasar, echan una piedra (5).

(1) Alexander, Op. cit., Vol. I, pg. 166.

(2) Callaway (Canon), The Religious System of Amazulu Natal, 1868, pg. 67.

(3) Andree, Op. cit.

(4) Id. id.

(5) Frazer, The Golden Bough, Vol. IX, (The Scapegoat), pg. 19, London, 1814. 
El viejo Magto, Jefe de los Bawenda, murió en Botokoa, mas sus restos fueron trasladados. En los lugares en que descansó el cadáver, todos los que tomaron parte en el traslado, depositaron una piedra.

Muchos de estos montones se encuentran en el país, en donde se llaman tsêaoelo, esto es, lugar de reposo; cuando un viajero pasa junto a uno de ellos, dice que allí descansa alguien y añade una piedra al carín, para tener buen viaje (1).

A la muerte de un hechicero Masaí o de una persona rica, se mata un buey o una cabra, con cuya grasa se unta el cuerpo y luégo lo llevan al lugar en que lo han de enterrar, y allí cavan un pequeño hneco, en el cual depositan el cadáver, que recubren con piedras. Quienquiera que pase por el lugar, y en cualquier tiempo, arroja una nueva piedra sobre el montón (2).

Cuando Burckhardt se encontró, en 1814, en el Nilo Superior, vió un cheic que llevaba

(1) Gottschlin, The Bawenda The Journal of the Anthropological Institute of Great Britain and Ireland, London, 1905, Vol. XXXV, pg. 381.

(2) Hollis, The Masai, Oxford, 1005, pgs. 305 y 306. 
un vaso lleno de piedrecillas blancás, sobre las cuales pronunció algunas oraciones, antes de depositarlas sobre una tumba (1).

La práctica de erigir carines sobre los sepulcros, se encuentra entre los Bischari, los Mensa y otras poblaciones que moran entre el Nilo y el Mar Rojo (2).

Las poblaciones árabes de Africa Septentrional, llaman kerkur a los carines, que son numerosísimos en estos países y que se encuentran, a menudo, en las partes más altas de los caminos.

Doutte halló úno en el paso Tizin Mîri, en el Alto Atlas, al Sur de Merahādo, a 3,200 metros sobre el nivel del mar y que era un montón de piedras, en el cual estaban clavados palos, de los que pendían jirones de tela. Era el kerkur de Sidi Ah'med o Mousa, sujeto que está enterrado a varios centenares de kilometros $y$ que es el marabout protector de Tazerouatt. La razón para que le hayan levantado un carín en lugar tan insólito, es que las gentes que por allí transitan, le tienen gran devoción. Así, cuando llegan a la cumbre, to-

(1) Andree, Op. cit.

(2) Id. id. 
man una piedra y la añaden al montón que, de este modo, crece paulatinamente. Los más supersticiosos ponen un bastón con un trapo.

No siempre está tan distante de la tumba el carín, pues es muy ordinario que se encuentre en el sitio en que, por primera vez, se ve un marabout célebre. A reces, es el kerkur el marabout, esto es, la tumba de un santo, del cual, en muchos casos, se ignora el nombre. No sólo en los sepulcros de estos venerados personajes se levantan carines, sino también en los sitios en que, según la tradición, brillaron sus virtudes (1).

Mas ; cosa muy singular! no es privilegio exclusivo de hombres famosos en santidad, el que, a su memoria, se erija esta clase de monumentos, ya que en los lugares en que se ha cometido un asesinato, o en el que alguien ha perecido de modo violento, todos los pasantes depositan una piedra, formándose así ca-

(1) Doutte, (Edmond, Magie et Religion dans l'Afrique du Nord, Alger, 1909, pgs. 420 a 427.

Chauvin (V.), Le Jet des pierres au pélerinage de la Mecque, Anvers, 1902, pgs. 279 y 280.

Montet, A special Mission to Morocco. Imperial Asiatic quarterly Review, Vol. XU, pg. 316, London, 1901. 


\section{ReLigín DEL INPERIO De los INOAS}

rines, que, en nada se diferencian de los que se construyen junto a los marabout (1).

En Figuid, se llaman estos montones, agrour, y los caminantes arrojan on ellos piedras, ignorando el significado del rito (2).

En Arabia, mientras aquellos que mueren do muerte ordinaria son simplemente enterrados, sobre la tumba de un asesinado se forma un montón de piedras, al cual todos los pasantes hacen una añadidura. Así, en recuerdo de un árabe muerto por los Wagogos 5 enterrado bajo un carín en el camino de Mizanza, los Wanya muézis que por allí pasan, recogen pequeñas piedras, para arrojarlas en el montón (3).

Según algunos árabes, este acto es una señal de la indignación que experimentan contra un criminal o asesino (4).

i1) Leared (Arthur), Morocco and the Moors, London, 1876, pg. 105.

Doutte, (Edmond), Magie et Religion dans l'Afrique du Nord, Alger, 1899, pg. 427.

(2) Doutte, (Edmond), Figuig Notes et impressions. La Géographie, Bulletin de la Société de Géographie de Paris, Paris, 1903, Vol. VII, pg. 197:

(3) Haron, Rites et usarges Funéraires Revue des traditions populaires, Paris, I894, Vol. XII, pg. 691.

(4) Chaurin (V.), Le Jet des pierres au pélerinage de la Mecque, Anvers, 1902, pg. 282. 
Ocho días antes de pasar por Midia $\mathrm{y}$ de practicar los ritos que ya analizamos, los peregrinos que van a la Meca, dirígense a un montón de piedras, situado a un cuarto de legua de la ciudad y cada uno de los concurrentes toma una piedra y la arroja sobre el carín, recitando el surra del Corán, en que Mahoma maldice a su tío, el impío Abou Lahab, por no haber creído en él (1).

Los Beduinos, en los lugares en que alguien ha muerto de modo trágico, con derramamiento de su sangre, forman carines, en los que los pasantes arrojan piedras. Si en el lugar han perecido varias personas, hacen un montón para cada una. Lo esencial para que se construya esta clase de monumentos, no es que allí se encuentre el cadáver del muerto, basta que en el sitio se haya derramado su sangre. A veces, como en la tumba del Oheik Amiry, arrojan piedras en señal de indignación y desprecio (2).

En Biskinta, en el Líbano, se encuentra la tumba de un druzo, del cual cuentan que se enterró vivo, para obtener méritos para la

(1) Chauvin, (V.), Op. cit., pg. 276.

(2) Janssen, Costumes des Arabes du Pays du Moab, Paris, 1903, pg. 356. 
vida futura que esperaba tener en este mundo, pues los Druzos creen en la transmigración. Los griegos ortodoxos del lugar, arrojan piedras en la tumba (1).

Al Este de Djebel Haurān, sobre un antiguo fortín romano, está la tumba de Cheik Wemār. Los Druzos la veneran, así como los nómadas $y$ los Arabes rezan sobre ella y depositan piedras (2).

Cerca de Birmana está la tumba de un marinero, que pereció asesinado y en ella los caminantes arrojan piedras, pues dicen que fué un mal hombre (3).

En el camino de Sychar, en el lugar desde el cual se ve la tumba de un santo musulmán, hay montones de piedras, hechos por los viajeros (4).

En la vecindad de Damasco, en Kferhaur, hay una tumba con un gran carín, y la leyenda asegura, que allí yace el bíblico Nemrod (5).

(1) Lessions (F.), Some Syrian Folklore notes gathered on Mount Lebanon, Folk Lore, Vol. IX, pg. 15, London, 1898.

(2) Dussaud, La Matérialisation de la priére on Orient. Bulletins et Mémoirs de la Société d'Anthropologie, V Serie, Vol. VII, Paris, 1906, pg. 215.

(3) Lessions, (F.), Loco cit.

(4) Lessions (F.), Loco cit.

(5) Burckhard, Travels in Syria and the Holly Land, London, 1822, pg. 46. 
En Siria $y$ otros lugares de Asia Menor, los sepulcros de los personajes renerados por santos, se llaman magan y en sus muros y grietas, los devotos depositan guijarros, o cuelgan de los árboles recinos, jirones de sus restiduras. Junto a algunos enterramientos, hay carines considerables (1).

Ouando un musulmán va por primera vez a un lugar sagrado, tal como Hebrón o la tumba de Moisés, hace un montón de piedras, o añade úna a un montón ya existente (2).

Entre Jerasán y Jericó, se pasa junto al sepulcro de un santo del Islam, sobre el cual los pasantes arrojan piedras. En muchos lugares de Palestina, donde ha muerto asesinado un hombre, hay carines, en los que todos los transeuntes arrojan guijarros, murmurando oraciones (3).

Entre los antignos Hebreos no era descocida esta costumbre y se la menciona repetidas veces en la Biblia, como por ejemplo, al

(1) Dussaud, La Matérialisation de la priére en Orient. Bulletins et Mémoirés de la Société d'Anthropologie, V Série,
Vol. VII, pg. 215, París, 1906.

(2) Rouse, Notes from Syria. Folk Lore, Vol. VI, pg. 173, London, 1895.

(3) Lessions (F), Some Syrian Folk-Lore notes gathered on Mount Lebanon. Folk-Lore, Tol. IX, pg. 158, London, 189. 
tratar de las tumbas de Achar y Absalón (1) $\boldsymbol{y}$ aun hoy, al pasal junto a esta última, los Judíos arrojan piedras y maldiciones contra el hijo desnaturalizado (2).

Es preciso recordar esta usanza, para penetrar el verdadero sentido de aquella sentencia de los Proverbios, de que el que da gloria al estulto, es como aquel que arroja una piedra en el carín (3); 5 la Vulgata, para comparar con un hecho más conocido en el mundo latino, traduce en el acervo de Mercurio o sea de Hermes, carines que, como hemos visto, eran algo diferentes de los Judíos (4).

La práctica de arrojar piedras en lugares determinados, era tenida por idolátrica y $\mathbf{s e}$ practicaba, no sólamente en las tumbas, si no también junto a monumentos formados por dos piedras verticales, sobre las cuales descansaba una horizontal y que se llamaban markolis (5).

(1) Andree, Ethnographische para llelen und Vergleiche.

(2) Rouse, Notes from Syria, Folk-Lore, Vol. VI, London, 1895, pg. 173.

Lessions, Loco cit.

(3) Bianus Waltonus, Biblia Poliglota, London, 1657, pg. 380 , columna hebrea.

(4) Proverbios, Cap. XXVI, versículo $8^{\circ}$.

(5) Buxtorfil, Lexicon Chaldaicum Talmudicum et rabbinicum, Lipsicae, 1896, pg. 640. 
El nombre hebreo de los carines, es margemaah (1).

En el barrio jndío de Praga, se encuentra Bet-Cbain, antiguo cementerio israelita; observando atentamente, sus viejos enterramientos, tapizados de musgo 5 en los que crecen plantas silvestres, se notan sobre muchos de ellos, especialmente en aquellos en que sacen personas de significación, montones de piedrecillas. Son estas ofrendas, de respeto al muerto y ningún judío piadoso que pasa junto a estos montones, falta a la antigua usanza de añadir un nuevo guijarro al carín (2).

En Eriwan, en Armenia, hay unos carines, en que, según la tradición, reposan los restos de unos monjes, que fueron lapidados. Los tártaros, al pasar, arrojan una nuera piedra en los montones $\mathrm{y}$ los cristianos quitan úna (3).

Los Ossetes del Cáncaso, sobre los restos de los que murieron heridos de rayo, erigen un alto montículo de piedras, junto al cual

(1) Ennery (M.), Dictionnaire Hebreu-français, Paris, 1891, pg. 145.

(2) Andree, Ethnographische Parallelen un Vergleicho.

(3) Andree, Op. cit. 
colocan una percha, de la que cuelgan la piel de un cabrón negro (1).

En el gran desierto de Gobi, hay carines en los lugares donde una caravana ha sido atacada y no de sus miembros muerto (2).

En el Tibet, hay mausoleos, formados por montones de piedras. Todos aquellos que sobrepasan el nivel de los demás, llevan una inscripción sanscrita, cuyo significado es, según únos «que el tesoro del cáliz de lotus sea santificado», $y$, según ótros, es obsceno. En machos de estos sepulcros hay un falo, tallado en piedra. En Leh (Ladak), estos monumentos se extendían por espacio de media milla inglesa $y$ miden seis a ocho pies de alto $y$ diez a quince de ancho. El número de piedras inscritas, llega a veces a mil y se asegura que hay Lamas, a quienes estos monumentos han costado hasta seiscientos mil thalers. Se hallan siempre junto a una calle y los naturales sólo pasan por su izquierda y cuando van a una empresa importante, compran a un lama una piedra inscrita y la depositan sobre una de es-

(1) Andree, Op. cit.

(2) Frazer, The Golden Bough, Vol. IX, (The Scapegoat), pgs. 13 y 14, London, 1914. 
tas tumbas, esperando, así, obtener buen éxito en su viaje (1).

En Ta-tsun, las piedras inscritas, son pedazos de pizarra $y$ se las deposita sobre las tumbas, como una ofrenda piadosa (2).

Los Tchouktchis practican la cremación y sobre las cenizas disponen piedras en forma de cuerpo humano, amontonando a lado, cuernos de reno. Los parientes van cada año a la tumba y añaden nuevas astas al montón (3).

En la isla de Lesbos, se encuentran, a menudo, al borde de las rutas, montones de pequeñas piedras, que los campesinos llaman anatematisrai y que indican el lugar donde se ha cometido un asesinato. Son los riajeros quienes los han formado; cada pasante pone una piedra, diciendo: «Dios perdone los pecados de la víctima! Maldito sea el matador!» El más notable de estos hacinamientos, se encuentra cerca del camino que conduce del lago mayor al menor. Acerca de él, cuentan que la región, en un tiempo, esturo dominada por un negro, que desvalijaba $y$ mataba a todos

(1) Andree, Op. cit.

(2) Cooper, Travels of a Pioner of Comerce, London, 1871, pg. 208.

(3) Andree, Op. cit.

Religión del Imperio de los Incas 
los riajeros; dicho negro fué muerto por su peluquero. Al pasar por la vecindad, la gente decía: «Dios perdone al peluquero. Maldito sea el negro!» (1).

Los rumanos de Transilvania creen que aquel que al momento de la muerte no turo encendida la «cera de bien morir», no tiene derecho para ser enterrado como los demás. Sus restos no pueden reposar en tierra santa, por el contrario, se los sepulta en lugar profano $y$ sobre su tumba, se forma un montón de ramas, al que todo pasante arroja algunas (2).

Los majiares ponen una piedra al pasar junto a una tumba (3).

En el Tirol, hay carines, en los que los pasantes arrojan piedras, en los lugares en que ha acontecido una muerte repentina (4). La misma costumbre se obserra en Suiza (5). En el Delfinado, no sólo se eriggen carines en los

(1) Georgeakis et I. Pineau, Le Folk-lore de Lesbos, Paris, 1894, pgs. 323 y 324.

(2) Frazer, The Golden Bough, Vol. IX, (The Scapegoat), pg. 16, Lond่on, 1914.

(3) Leibrecht, Zur Volkskunde, Heilbronn, 1878, pg. 269.

(4) Joane (A.), Excursion dans lo Dauphiné. Le Tour du Monde, Paris, 1869, Vol. II, pg. 375.

(5) Andree, Op. cit. 
lugares en donde un hombre ha sido víctima de un crimen, sino también en los que alguien ha perecido, víctima de un accidente de la naturaleza (1).

En el Niévre, hay una cruz, junto a la cual los caminantes arrojan sus bastones y a poca distancia, un montón de palitos, sobre la tumba de un asesinado (2).

Los Celtas nunca pasaban junto al sepulcro de uno de los suyos, sin depositar una piedra, o un poco de tierra (3).

En el departamento de la Obarant Inferior, existen carines en las cumbres de las colinas y a lo largo de los caminos; cada vez que un campesino llega a uno de estos montones deposita en ellos una nueva piedra (4).

En el Condado de Longford, en Irlanda, a la vera de los caminos, hay montículos de

(1) Joane, Op. eit.

(2) Saisnel de la Sage, Croyances et legendes du centro de la France, Vol. II, pg, 76, París, 1875.

(3) Irish Folk-lore reprinted of a Statistical Account or Parochial Survey of Ireland, drawn from the conmucations of the Clergy by William Shair Mason, Dublin, 1814 a 1819, FolkLore, Vol. VI, pg. 6.3, Lomion, 1898.

(4) Buron Chandrug de Carazans, Memoire sur les antiquites celtiques et gauluiveo du departement de la Charante Inferieur. Memoirs de la Societé Royal des Antiquaires do France, París, 1823, pg. 61. 
piedras, a los que todo pasante hace una añadidura, en los lugares en donde alguien ba muerto asesinado o de otro modo riolento (1). Igual costumbre se obserra en Tipperars, en el condado de Dublín y en el de Wilkow (2).

En medio de la floresta, en un lugar fragoso, en el camino quo va de Schmauneivitz a Lausa, en territorio de Leipzig, hay nna tumba en medio de los árboles, en donde yace una sirvienta, que regresando de un baile, fué asesinada por un muchacho, carnicero de oficio. Los que por allí transitan, arrojan tres ramas de pino sobre el pequeño montículo, que marca el lugar del crimen. El hacinamiento sería muy considerable, si no se recogiera anualmente lo acumulado.

En Baden es costumbre arrojar ramas en los sitios, donde alguien ha sido asesinado (3). En Pomerania y Prusia Occidental, las almas de los suicidas son muy temidas y en las tumbas de estos desgraciados, las que están situadas en el lugar donde atentaron contra sus vidas, todos los pasantes arrojan piedras o

(1) Leibrecht, Zur Volkskunde, Heilbronn 1878, pg. 272.

(2) Haddon, A Batch of Irish Folk-Lore, Tol. IV, pg. 360, London, 1893.

(3) Andree, Op. cit. 
palos, ya que si tal no hicieran, creen que el espíritu del suicida les atormentaría en sueños $y$ no les daría reposo (1).

En Suecia sobre la tumba de dos hombres que se mataron mutuamente, hay un montón de ramitas, que constantemente crece, con las nuevas ramas que añaden los transeuntes (2).

Hay en Unalaska, tumbas en las que todo aquel que, junto a ellas pasa, deposita una piedra (3).

Entre los Osages, sobre el enterramiento de un jefe, se erigía un montecillo, que luégo se engrandecía, pues cada visitante depositaba en él un poco de tierra (4).

Esta costumbre era observada, además, por otras tribus indígenas de Norte América, que ofrendaban a las tumbas de los guerreros notables un poco de tierra, que, para el efecto, llevaban los viajeros cuidadosamente, desde dis. tancias, a veces, considerables (5).

(1) Frazer, Op. cit., Vol. IX, pg. 27.

(2) Leibrech, Zur Volkskunde. Heilbronn, 1878, pg. 272.

(3) Andree, Op. cit.

(4) Thomas, (Cyrus), The Problem of the Ohio Mound, Washington, 1889, pg. 12.

(5) Smith (W.), The History of Wisconsin, Part. II, Vol. III, Madinson (Wis), 1854, pgs. 245 y 246. 
Entre los Oheroquíes, para perpetuar la memoria de los jefes muertos en los bosques, los viajeros arrojan piedras en los sitios en que perecieron. En donde no había piedras, se servían de tierra. Los Mohawk, al depositar las piedras, exclamaban: "Abuelo te cubro» (1).

Los Cougaris o Santis, del Sur de California, cuando alguien perece asesinado, en el lugar en que tal cosa ha acontecido, hacen un montón de piedras o palos, al que todo viajero hace una añadidura, en señal de respeto por el difunto (2).

En Venezuela, hay carines en los sitios en que un hombre ha muerto violentamente, a los que cada pasante añade un nuevo guijarro; junto al montón está una sencilla y rústica cruz (3).

Oomo, por lo expuesto, puede verse, el amontonar piedras sobre una sepultura, arro-

(1) Adair, 'J.), The History of the American Indians, London, I775, pgs. 181 y 85, No. $3^{\circ}$.

(2) Schoolcraft, History of Indians Tribes of the United States 1854, Part. VI, pg. 155, citado por Jarrow, A further Contribution to the Study of the Mortuary Customs of the American North Indians $1^{\text {th }}$ Annual Report of the Bureau of Ethnology 1879 a 1880, Washington, 1881, pg. 132.

(3) Andree, Op. cit. 
jaudo úna todos los que junto a ella transitan, es una de las formas más comunes del rito, que venimos estudiando; la interpretación del por qué de esta usanza no será difícil para el lector que haya seguido, atentamente, la exposición de otras formas del rito, que en las páginas anteriores hemos hecho.

Nada satisfactorio nos parece el explicar los carines que se lavantan sobre enterramientos, diciendo que el primitivo, incapaz de distinguir lo inmaterial de lo material, lo abstracto de lo concreto, se siente asaltado por ragos terrores, expuesto a mal definidos peligros en los escenarios de grandes crímenes o desgracias. El lugar parécele encantado. Los torcedores recuerdos que se acumulan en su mente, si no se transforman en duendes y fantasmas, oprimen su fantasía con terrible peso. Su impulso es huír del temible sitio, arrojar ol peso que le atormenta cual pesadilla. Así, en su sencilla manera material, piensa que puede hacerlo, arrojando algo en el horrible lugar y alejándose. ¿̇Por qué el contagio de la desgracia y la angustia que detienen los latidos de su corazón, no los desfiará do sí, encarnándolos en un objeto material? ¿ No reunirá en la piedra o rama todas las influencias nocivas, 
que le atormentan, para continuar su ruta en paz y seguridad? Una manera de pensar semejante, (si tales divagaciones de la mente en las tinieblas de la ignorancia, merecen el nombre de pensamientos), parece explicar la costumbre, observada por los viajeros de muchos países, de arrojar piedras o palos, en los lugares en que algo terrible ha acontecido, o en que se ha cometido un crimen (1).

Más natural, más sencillo, más de acuerdo con la mentalidad del salvaje, es el suponer que, asaltado por grandes temores, al pasar ante el escenario de un crimen y considerándose expuesto a determinados males, que en su modo de juzgar las cosas material y más sensitivo que intelectual, tiene por propios del lugar, como producidos por una fuerza invisible, inmanente o residente en él, trate de impedir la emanación de dicha virtud, cegando, como si dijéramos así, su fuente o biriendo a aquel poder, que sus primitivas $y$ mal diferenciadas ideas, concibe como algo corpóreo y material, si es que no les da forma más precisa de fan-

(1) Frazer, [J. G.], The Golden Bough Vol. IX, [The Scapegoat], London, 1914, pg. 13. 
tasmas, sombras o bestias feroces (1), para, impedir que le sigan (2).

Acto natural e instintivo en el hombre poseído de miedo, es el alejarse corriendo del objeto de sus temores, procurando separarse de él, lo más posible y acumular entre dicho objeto y él, el mayor número de obstáculos. Y si este sentimiento es producido por un objeto vivo, ¿ no será el gesto más espontáneo de aquel hombre, arrojarle piedras?

Varios de los hechos que hemos citado y entre ótros con gran claridad, las costumbres australianas, bagandas y malgaches, demuestran que el fin primero $y$ primordial, de arrojar piedras en un sitio determinado, es el impedir la emanación de la fuerza mágica nociva.

Ya, en su lugar, estndiamos cómo los primitivos entienden la naturaleza de aquella virtud, fundamento de las más rudimentarias concepciones religiosas y que pertenece a un estado embrionario, en el que la religión y la magia no están aún diferenciadas. Dichos conceptos nada tienen de lógicos, ni de claros y

(1) Vide supra, pg. 189.

(2) Vide supra, pg. 196.

(3) Vide supra, pg. 184 y sig. 
entre sus constantes contradiccionos, no es la menor, la de entender que aquella fuerza invisible, inteligente e impersonal es, por otra parte, material, trasmisible, contagiosa y activa (1).

Pues bien, dados estos antecedentes, muy fácil nos será comprender la actitud del primitivo, que acumula obstáculos sobre la fuente de donde mana aquel poder, cuyos efectos teme, para así, impedir su difusión.

Imaginémonos, por un momento, lo que haría un homble rudo, ignorante de los adelantos modernos, que se encontrase junto a un orificio practicado en el suelo, que emanase gases, que él supiese le eran desagradables o nociros. ¿Trataría, acaso, aquel hombre de encarnar la molestia $\mathrm{y}$ daño, producidos por las emanaciones, en un objeto material, para arrojarlos sobre el lugar de donde se originan; o se serviría más bien de los cuerpos sólidos y resistentes, que encontrase a su alcance, para tapar aquel orificio e impedir la salida del gas?

La respuesta no puede ser dudosa y no so objete que el gas $y$ el poder mana, son dos

(1) Vide supra, pg. 70 . 
cosas enteramente diferentes; que de cuantos ejemplos pueden citarse, parécenos que la emanación de mana, con lo que mejor se puede comparar, es con el desprendimiento de gases, o con la producción de electricidad.

El deseo de ponerse al abrigo del poder del muerto que, generalmente para el primivo, es malévolo y peligroso, debe haber contribuído, en gran parte, al desarrollo universal de la costumbre de enterrar los cadáveres (1).

Este mismo deseo, es el que hace que el viajero deposite piedras, al pasar ante aquellas tumbas, que considera como especialmente peligrosas, ya a causa del carácter del que en ellas yace (gemelos, hechiceros, hombres ricos, extranjeros, malvados), ya por el modo cómo terminó sus días (asesinato, suicidio, fulminación, etc. etc.), esto es, aquellas en que juzga mora un espíritu, especialmento poderoso, o una alma airada y deseosa de venganza.

Pero el primitivo, el campesino, no sólo temen el lugar en que reposa un cadáver, no

(1) Los Uskoques para impedir que los muertos se apareciesen $y$ molestasen a sus parientes, ponían sobre la cabeza y pies de los cadáveres, al enterrarlos, pesadas piedras. Leibrecht, Zur Volksknnde, Heilbronn, 1878, pg. 275. 
sólo allí acumulan piedras, sino que les basta que el sitio haya sido impregnado con la sangre del difunto, aunque su cuerpo descanse tranquilo a considerable distancia. iNo es la sangre el rehículo de la vida, el elemento vital por excelencia, aquello en que se cree reside el espíritu? Así, al rerter su sangre, al impregnar con ella la arena, aquel cuerpo que murió ríctima de alevosa herida, no perdió su espíritu vital? ino se compenetró con la tierra, al teñirse ésta de rojo? $Y$ por lo mismo que allí el pobre espíritu está 'privado de su compañero y receptáculo, por obra de cruel enemigo, estará más airado y deseoso de venganza $\boldsymbol{y}$ será, por ende, más temible.

No debe extrañarnos y sorprendernos, el que el mismo rito que se practica ante la tumba de un mago o de un asesinado, se verifique también ante el sepulcro que encierra las venoradas reliquias de un santo, ya que sabido es por todos aquellos que han estudiado las costumbres de los pueblos no civilizados, cuán débil e imperceptible es la línea 'que separa lo impuro de lo sagrado $y$ con cuanta facilidad un mismo objeto pasa de una a otra categoría, a tal punto de parecer justificada la afirmación, de que ambos atributos no son sino dife- 
rentes formas de erolución de un mismo concepto fundamental; el de sagrado.

Es de notarse, además, que entre el mago y el santo, para las masas ignorantes, apenas hay diferencia. ¿ $\mathrm{No}_{0}$ es para el vulgo, el síntoma, la esencia de la santidad, el practicar milagros? Un santo es tál para las gentes rudas, no por la ética superior de su vida, sino por la faculdad que posee de trastornar las lejes de la naturaleza en pro de sus derotos. Así, la virtud que eflaye de su sepulcro, es una entidad de la cual conriene desconfiar, como se desconfía de una corriente de alta tensión, que, como puede producir luz y fuerza, empleada en circunstancias propicias, pnede ser causa de muerte, si al servirse de ella, no se toman las debidas precauciones.

Lo que acabamos de ver nos preparará para el estudio de otra serie de casos, en los que se levanta el carín en un sitio sagrado.

En algunos, como en aquellos que expondremos a continuación, es permitido el suponer, que a la tumba de un personaje renerado, debe el lugar su reputación de santo.

Así, en la India, en el pueblo de Niamatpur, junto al templo de Anktak Bir, hay un 
carín de piedras calcáreas, en el que todo pasante deposita un guijarro (1).

En Escocia, existe, en Papa Westra, nna capilla, Tredwels, a cuga puerta hay un carín, en donde era superstición del vulgo de aquel lugar, que reneraba esta capilla más que otra alguna, no entrar nunca sin arrojar una piedra al montón (2).

Para los irlandeses es un acto de devoción, poner una nueva piedra en los carines que hay junto a pilares que tienen una cruz (3).

Entre los peregrinajes del país de Salzbourgo, ocupa el primer lugar, el de San Wolfang, capilla pequeña, rodeada de una fuente sagrada, situada en la parte alta de una colina, a la cual se sube por dos lados, por senderos cabiertos de bosques. Los peregrinos, entre los cuales se encuentran bávaros, que vienen desde muy lejos, traen con gran trabajo grandes cantos, pues, segín la leyenda, cuando la can-

(1) Ilartland. (Edwin Sidney), The Legend of Perseus, Vol. II, pg. 206, London, 1895.

(2) Martin, A description of the Western islands of Scotland in Pinkerton, Voyages and Trarels, Tol. III, 691, London, 181.

(3) Leibrech, Op. cit., pg. 279. 
tidad de piedras sea suficiente, el santo se edificará una nueva y grande iglesia (1).

En Palestina $y$ otros países islámicos, los peregrinos levantan carines, en los lugares desde donde, por rez primera, contemplan una mezquita célebre (2).

En Sudero, isla del archipiélago de Foere, hay montones de piedras llamadas kirjarheygfur, en los puntos desde donde se ve por primera vez una iglesia. Los caminantes añaden, a menudo, una nueva piedra al montículo, cuando pasan junto a él (3).

En Persia, los riajeros piadosos, al ver la villa santa de Meschhed o la de Kim, acumulan piedras en determinados lugares $y$ cuelgan trapos de todos colores en los arbustos del camino, mientras expresan su fe $y$ devoción por medio de himnos $y$ cánticos (4).

Cerca de Dundalk, en Irlanda, hay un dolmen llamado la tumba de Cuchullin, a la-

(1) Andree, (R.), Ethnographische Parallelen und Vergleiche.

(2) Jansen, Costumes des Arabes du Pays de Moab, Paris, 1:01, pg. 336 .

(3) Leibrecht, Zur Tolkskunde Feilbronn, 1878, pg. 273.

(4) Andree, Op. cit. Leibrecht, Op. cit., pg. 279. 
do del cual hay un montón de piedras, en el que los transeuntes al pasar arrojan una más (2).

Mas, si en algunos de los ejemplos antecedentes, es posible sospechar, con más o menos probabilidad, que la santidad del lugar es debida a un enterramiento, hay otros casos en que no cabe tal suposición y en que es preciso reconocer, que lo que motiva el hacinamiento de piedras, es la virtud que se cree posee el sitio, por una u otra circunstancia, virtud sagrada, activa y trasmisible, que sólo puede ser manejada por aquellos que están dotados de cualidades especiales, ya que es sumamente peligroso manejar potencial tan temible (1). Por lo cual, todos los profanos, procuran ponerse al abrigo de sus ataques, hacinando sobre el lugar en que está impregnada, piedras, palos o tierra, para impedir su emanación.

Innecesario nos parece recalcar sobre principio tan conocido como es el de que, para las mentes primitivas, apenas existe diferencia entre lo sagrado y lo impuro $\mathrm{y}$ en que ambas cualidades, como igualmente peligrosas, hacen

(1) Leibrecht, Op, cit., pg. 268.

(2) Vide supra, rgะ.70. 
que tal o cual objeto, o determinada acción, sean tabú (1).

En Marruecos, se levantan carines para conmemorar el pasaje del Sultán, mas, una vez hechos, no es costumbre depositar en ellos nuevas piedras (2). Nada de extrañar tiene esta usanza. El atribuír poder mágico a los reyes y el creerlos llenos de virtudes extraordinarias, son, podemos estar seguros, uno de los orígenes y fundamentos de la realeza: muchos son los pueblos que han tenido reyes divinos (3), y, aún en tiempos relativamente modernos, se ha creído que podían curar, de modo milagroso, ciertas enfermedades.

Isabel de Inglaterra y todos sus sucesores, excepción hecha de Guillermo III, hasta épo. cas tan tardías como los reinados de Jacobo II y de Ana, ejercieron su mágica virtud, de sa-

(1) Frazer, The Golden Bough Vol. III, (Taboo and the perils of the Soul), pgs. 224 y 225, London, 1914.

(2) Doutte (Edmond), Magie et Religion dans l'Afrique du Nord, Alger, 1909, pg. 427.

(3) Frazer, Lectures on the Early History of Kingship, London, 1905.

Id, The Golden Bough, Vol. I, (The Magic Art and the Evolution of kings), pgs. 44 a 51, 332 a 421, London, 1913, Vol. III, (Taboo and the Perils of the Soul), pgs. 1 a 25, 131 a 137, London, 1914 Vol, IV, (The Dying God), pgs. 1 a 195, London, 1914.

Religion del Imperio de los Incas 
nar determinadas dolencias (1). Se cuenta que, cuando Francisco I, cautivo después de la rota de Paría, pasó por Barcelona, acudieron a él presurosos muchos enfermos, esperando que les derolviese la salud. Así, bien podemos suponer que el origen de formar hacinamientos, en memoria de la presencia del Sultán, es el deseo de cubrir la tierra que ha estado en contacto con la persona sagrada y que, por tanto, es de suponer está cargada de mana.

A igual causa deben obedecer los montículos, que se obserran junto a la Roca de Hesi el Ohattatin, en Wadi Mokattel, en la península de Sinaí, que los Arabes identifican con la roca, de la cual hizo Noisés manar agua, para calmar la sed de los Israelitas. Los indígenas cuentan que los Hebreos, una vez que bebieron, elevaron carines en las recindades del milagro. Los Arabes actuales continúan esta costumbre, en conmemoración del portento, pensando, de este modo, obtener el favor de Moisés. Así, arrojan piedras en los carines, por un amigo enfermo, para que recobre la salud (2).

(1) Frazer, The Golden Bough, Vol. I, (The Magic Art and Erolution of kings), pgs 368 y 369, London, 1913 ,

(2) Andree, Op, cit. 
No hay duda, que los moradores de Sinaí, creen que algo de la virtud portentosa de Moisés, quedó impregnada en la roca, de donde hizo brotar agua; $y$ por esto, temerosos de su poder o deseando conservarlo, acumulan piedras, para impedir su difusión.

En Senegambia hay carines en los sitios en que los viajeros dicen la oración de la tarde (1).

En Provenza, en la montaña de SainteBaumé, hay una cuera venerada, que la tradición relaciona con Santa María Magdalena. Los devotos que allí van, acostumbran subir a la cumbre del monte $\Sigma$ erigir montoncitos de piedras, como testimonio de su piedad y para adivinar si serán dichosos cuando proyectan casarse (2).

Para los Osetes, son sagradas algunas de las altas cimas del Cáucaso, en las que ahora invocan a San Jorge, a San Miguel, a San Nicolás o al profeta Elías. Allí levantan carines, ante los cuales oran (3).

En Palestina, hacia el fin del Ouãdy Gerãfeh, los Tiahã, en nna roca enorme, desta-

(1) Leibrecht, Zur Volkskunde, Heilbronn, 1878, pg. 276 ,

(2) Berenger Ferand, Notes sur las Cultes de la Montagne Saint-Baumé-Revue d'Anthropologie $3^{\text {me }}$ Serie, Vol. III, Paris, 1888.

(3) Andree, Op. cit. 
cada de la montaña, al pasar arrojan siempre piedras pequeñas (1).

Los Mongoles, en los pasos difíciles y en o tros muchos lugares, tienen lo que llaman obo, esto es, un altar al aire libre, que, según la tradición, fué consagrado por un lama célebre, y en el que se re, algunas reces, rudas imágenes de Buddha y en donde los viajeros, al pasar, depositan un pedazo de papel o de la piel de su manto (2). Posible es que esta usanza no sea sino una forma evolucionada de otro de los grupos en que puede diridirse el rito que estudiamos, correspondiente a un grado más perfecto de religiosidad. Ejemplos de tales mutaciones no faltan. Mas no es posible suponer otro tanto de las prácticas provenzales y palestinas, así como de aquellas que se observan junto a árboles sagrados, en las que no cabe duda de que la santidad del sitio y su wakonda, determinan la erección de los carines. Son estas prácticas primitivas, correspondientes a un nivel muy inferior de religiosidad, conservadas en pueblos adelantados, mer-

(1) Janssen, Les Costumes des Arabes du Pajs de Moab, Paris, 1:15, pg. 336.

(2) Poussielyue, Relation de Voyage de Shang-hai a Moscou. Le Tour du Moud, Tol. XI, Paris, 1865, pg. 246. 
ced a una de aquellas extraordinarias (no por lo poco. frecuentes) supervirencias, a las que se debe, permitásenos la comparación, que se conserven fósiles de extremada edad, propios de ambientes religiosos, semejantes a aquellos en que viven hoy las tribus salvajes.

En la llanura, por donde pasa el río Colorado, región desierta, tristísima y sin árboles, hay un algarrobo, de dimensiones considerables y muy añejo, que sobresale en medio de la soledad de la pampa y rompe la angustiosa monotonía del desierto. Tiénenlo por muy poderoso y llámanlo gualichu, roz que, en anca significa espíritu o dios y al cual todos los indios que junto a él pasan, ofrecen una prenda de vestir, unos hilos de color, tabaco $y$, a veces, monedas, o aquellos que no tienen otra cosa mejor, una cerda de la cola de su caballo, que atan de una rama. Los nás devotos llegan a sacrificarle sus cabalgaduras, el más precioso bien de estos salvajes. Los dones colócanjos en las hendiduras del tronco, o cuélganlos de las ramas. No hay indio, por miserable que sea, que al pasar no deje una ofrenda (1).

(1) D'Orbigny A.), Voyage dans l'Amerique Meridionale, Vol. II, pgs. 156 a 161, París, 1839 a 43. 
El Santuario Hopi, Gran Masanûu, uno de los más conocidos de la meseta oriental, es una roca, a cuyo pie hay un gran montón de palitos y ramas, que han sido puestos por los que por allí pasan con leña, sin que falten ofrendas de mayor valor, tales como bastones de oración o rasos.

El pequeño Masanûu está a alguna distancia del antecedente $y$ es cuatro montones de piedras $y$ astillas, que han sido erigidos por los leñadores.

Hay muchos carines semejantes en el país Hopi (1).

Al pasar junto a un árbol, que parece muy viejo, los Oraherrero colocan palitos en las ramas, hablan con el árbol y tiénenlo por sagrado, si se imaginan que les responde. Los Obambo arrojan hierba y ramas en un árbol de este género, pues creen que es la tumba de un héroe (2).

En los alrededores de Kum, en Persia, se ven árboles, en los que los pasantes amarran trapos (3).

(1) Fewks (Walter J.), Hopi Schirines near East Mese, Arizona. American Anthropologist New Series, Vol. VIII, pg. 35̆4, New York, 1906.

(2) Dudley Kid, The essential Kafir, London, 1914.

(3) Andree, Ethnographische parallelen und Vergleiche. 
Los Sankes y Foxes, rara vez pasan por junto a una cuera, roca u otro objeto extraordinario, sin dejar algo de tabaco (1).

En las vecindades de ciertas minas de cobre, a sesenta $y$ nueve grados de latitud, los mineros ponen guijarros sobre ciertas piedras planas, cada rez que, junto a ellas transi$\tan (2)$.

El santuario de la diosa, madre de los Juncales, en el Norce de la India, es un hacinamiento de piedras o palos, a cuya formación todo pasante debe contribuír, so pena de que irritada la diosa, envíe contra él un tigre o leopardo (3).

Los Wahamba, creen que ciertos lugares peligrosos, son la residencia de malos espíritus; en ellos todo riajero debe danzar un momento y depositar una piedra (4).

En Tonkín, bay montículos en los que las mujeres creen reside un espíritu, al que invocan para tener buena suerte cuando ran al 301.

(1) Dorman, Primitive Superstitions, New York, 188, pg.

(2) Andree, Op. cit.

(3) Frazer, The Golden Bough, Tol. IX, The Scapegoat), pg. 27, London, 1914.

(4) Frazer, Op. cit., Vol. IX, pg. 29. 
mercado, ofreciéndole bacer una añadidura al carín, al regreso de la feria, si en ella les ha ido bien.

En Ceylán, hay carines asociados con Gamese, dios con cabeza de elefante.

En el Japón, hay un montículo semejante, junto a un árbol en el templo de Hatchiman $y$ otro cerca de una estatua de Budha. $Y$ antigua costumbre de los germanos fué la de amontonar piedras, junto a las imágenes de ciertos dioses (1).

Si todos los hechos examinados hasta aquí, parecen estar en armonía con la hipótesis que para explicarlos hemos sugerido, debemos ahora proceder al estudio de otro grupo de casos, que, a primera vista, justifican la teoría emitida por el sabio profesor Frazer, en su inimitable Ramo de Oro. Mirándolos con más detención, juzgamos que, originariamente, son debidos a las mismas causas que las de los ya examinados, si bien, por circunstancias fáciles de explicar, con el transcurso del tiempo, habiéndose olvidado su motivo fundamental, atribúyeseles como fin, lo que antes no fué sino una consecuencia y accidente. y 78.

(1) Leibrecht, Zur Volkskunde, Heilbronn, 1873, pg. 27 
En las islas Salomón, es costumbre general, arrojar palos o piedras en un montón, en las bajadas rápidas o en los pasos difíciles. Dicen que arrojan la fatiga y no dan al acto ningún carácter religioso (1).

En un bosque, en la isla de Norfolk, hay un carín, erigido para tener buen descenso a la playa, y en donde, al colocar las piedras, decían los naturales: "Allí va mi fatiga» (2).

En la parte occidental de la isla de Timor, los hombres o mujeres que hacen un largo o fatigoso viaje, llevan consigo hojas, que luego arrojan en lugares determinados por la tradición. La fatiga que sienten, creen dejarla allí. Algunos se sirven de piedras, en vez de hojas (3).

En el Archipiélago Babar, los que están cansados, frótanse las piernas con piedras, las que luégo dejan en determinados sitios, juzgando así descansar (4).

(1) Codrington, "The Melanesians, Oxford, 1891, pg. 185, nota.

(2) Codrington, Loco cit.

(3) Frazer, The Golden Bough, Vol. IX, (The Scapegoat), London, 1914, pg. 8.

(4) Frazer, Op. cit., pg. 9. 
Los Kosa Kafires y los Oafres practican este rito para obtener vigor (1).

Entre los Zambesis, los montones son de palos. Antes de depositarlos, se frotan con ellos las piernas, esperando librarse de la fatiga y obtener mayor vigor, para continuar la ruta (2).

En el altiplano Nyasa Tanganik, en la cumbre de muchas escarpadas colinas, hay pequeños carines. El intérprete de Boileau le dijo que eran montones de suerte. Los indígenas, antes de subir con sus cargas, toman un guijarro, escupen en él y después de frotárselo en las pantorillas, lo depositan en el montón: esto lo hacen para que sus piernas sean ágiles (3).

Los Seeds llaman m'zemu, a carines que hay en los pasos, en los que arrojan una piedra, cuando por allí transitan. Junto a una gran roca, los que acompañaban al viajero Grant, depositaron guijarros (4).

(1) Dudley Kidd, The Essential Kafir, London, 1904. Frazer, Op. cit., pg. 11.

(2) Dudley Fidd, The Essential Kafir, London, 1904.

(3) Boileau, The Nyasa Platean The Geographical Jour nal, Vol. XIII, pg. 589, London, 1899.

Dudley Fidd, Op. cit.

(4) Grant (J. A.), A Walk across Africa-Edimbourgh, 1864, pgs. 133 y 34. 
Speke, en su largo viaje de Zanzíbar al Mediterráneo, recorriendo el valle de Uthingu, en la provincia de Usensa, encontró a lo largo del camino, montículos, en los que todos los pasantes arrojan una piedra. Carines semejantes halló en el territorio de los Wahuma (1) y en Somalís, en donde juran por algunos de estos carines, así como por ciertas piedras o árboles sagrados (2).

Los M'rus, cuando salen de viaje, toman por la mañana un retoño de hierba, $y$ el que conduce la partida, entrando en un río hasta que el agua le cubra la cintura, dirige una oración a ésta, mientras los ótros, que permanecen en actitud reverente en la orilla, plan$\tan$ en la arena los retoños.

Estas mismas gentes, al atraresar una colina, cuando llegan a la cumbre, cogen un poco de hierba y la colocan sobre los marchitos restos de otras ofrendas semejantes, hechas por los viajeros que les han precedido (3).

(1) Andree, Ethnographische Parallelen und Vergleiche.

(2) Burton, First Foutsteps in East Africa; or an exploration of Harar, London, 1856, pg. 113.

(3) Lewin, Wild Races of South Eastern India, London, 1870, pgs. 232 y 233. 
En el Indostán, los carines son llamados peerke-jaggeh (1).

En Birma, en las montañas que separan este país del de Siam, se encuentran, en la parte más alta de los collados, carines, en los que los viajeros depositan flores y hojas (2).

En Laos, se ven carines en las cumbres, en donde los caminantes depositan una hoja o rama, pidiendo al Señor de los Diamantes, buena ventura y larga vida (3).

En la cumbre del paso que lleva a $\mathrm{Du}$ lau-kuo, capital del principado mongol de Koko-nor, hay un obo, o montón de piedras, al cual todos los viajeros añaden siempre algo al pasar (4).

Esta costumbre es muy general en el Tibet; ya hemos tenido ocasión de tratar de los carines, que en este país se encuentran en en las cumbres de las montañas y de señalar su explicación (5). 1864.

(1) Grant, A Walk across Africa, pg. 134, Edimbourgh,

(2) Bastian (Adolf), Reisen in Birma in the Jahren, 18611862, Leipzig, 1866, pgs. 483, 484.

(3) Frazer, Op. cit., Vol. IX, pg. 29.

(4) Rockill, The land of the Lama, London, 1891, pg. 126.

(5) Vide supra, pg. 195.. 
En las ruinas de la antigna cindad de Khara Korum, se ve una gran tortuga de piedra, en la que hay un obo, formado por multitad de piedrecillas (1).

En Corea, existe un verdadero culto a las montañas, cuyos espíritus se llaman San-Shin Rijüg, que tienen templos en casi todos los montes del país, especialmente junto a un gran árbol, o a una piedra plana. Estos genios son masculinos, mas no carecen de mujeres. El tigre, que tan temido es en Oorea, creen que sirve a estos espíritus o que es su encarnación (2).

Al borde de las rutas, en los pasos más frecuentados, hay pequeñas pagodas, dedicadas a los dioses del lugar. Son templetes de madera, de un metro cincuenta en cuadro, cubiertos con tejas y cuyo interior tiene una imagen, figuras de tigres, $\theta$ inscripciones chinas, pintadas en los muros (3).

Cuando Gowland, viajaba por Oorea, al llegar al pueblo de Bambe, al pie del paso de

(1) Commandant de Bonillanc de Lacoste, Au pays sacré des anciens Turcs ot des Mongols, Paris, 1911, pg. 64.

(2) Bishop, Korea \&. and her Neighbours, London, 1898, Vol. II, pgs. 243 y 244.

(3) Bret, Dans la Corée Septeutrional. Misions Catholiques, Vol. XXXI, pg. 237, Lyon, 1899. 
Mungyön, que atraviesa la cordillera, en que se encuentra el divorsizm aquarum de la península, los indígenas, que le acompañaban, le requirieron que sacrificase un cerdo al espíritu del paso, a fin de no ser atacados por los tigres.

Los coreanos mataron al animal, bebieron un poco de su sangre $y$ lo pusieron sobre el lomo de una mula $\mathrm{y}$ al pasar ante el templo del genio del monte, llevaron el cerdo al santuario, donde el sacerdote, que lo servía, hizo ciertas ceremonias, derolviendo luégo la carne a los riajeros, en cambio de una pequeña retribución en dinero (1). No siempre reciben estos dioses sacrificios de tanto precio, ya que hay viajeros que se contentan con depositar en el santuario, zapatos viejos, pequeñas cantidades de arroz, o con colgar unos trapos, si es que no se limitan a hacer en el carín, las usuales ofrendas (2).

En los pasos menos importantes, hay, por lo menos, un árbol sagrado, al pie del cual está un montón de piedras.

(1) Gouland, Notes on the Dolnens and other Antiquities Korea. The Journal of the Anthropological Institute of Grat Britain and Ireland, Vol. XXIV, London, 1895.

(2) Bishop, Op. cit., Vol. I, pg. 147. 
Estos carines, así como aquellos que se encuentran junto a los templetes de los dioses de las montañas, son hechos por los viajeros, que, al subir la cuesta, recogen una piedra, más o menos cerca de la cúspide, según sea su devoción (1), en la que escupen antes de depositarla en el montón (2).

No sólo guijarros arrojan en estos lugares

- los pasantes, sino que creen que es muy grata oferta a los genios de aquellos lugares, un pedazo de papel o de calicud (3).

Estos ritos no se practican tan solamente en las cúspides de los cerros, sino también a la salida de algunas poblaciones, en las que es común, que el carín se encuentre al pie de un poste, cuya punta está esculpida rudamente, en forma de una cabeza humana y de la cual penden largas cuerdas (4).

Hay también montones en las encrucijadas (5). En fin, según advierte un perspicaz observador, esta costumbre es general en to-

(1) Bret, Op. cit., pg. 237.

(2) Bishop, Op. cil., Vo. I, pg. 147, y II, pg. 223.

Gowland, Loco cit.

(3) Gowland, Op. cit.

(4) Bishop, Op. cit., Vol. II, 223,

(5) Id, id. 
dos aquellos lugares, en que se cree que reside un espíritu maligno (1).

Los indios Hopis, al acercarse a un pueblo, toman una piedrecita $y$ la arrojan sobre un carín, que se encuentra a la entrada de la población y que, según los Hopis, es el templo de Masamû, dios de los muertos.

Fewkes excavó uno de estos carines, junto a un pueblo abandonado. Era un pequeño reducto y contenía muchas piedras de formas singulares, que recordaban las que los indios Paeblos tienen por fetiches, siendo algúnas, rudamente talladas, en forma de animales (2).

En el Norte de Méjico, en los pasos de las cordilleras, se encnentran carines, formados con hierba, palos y piedras. Aunque de altura no despreciable, ya que algunos alcanzan hasta un metro cincuenta, carecen estos montones de todo orden. Todo indio, al pasar, añade a ellos algo, a fin de obtener vigor, para continuar su viaje. Entre los Taraumaras, sólo los viejos obserran esta costumbre.

(1) Bishop, Op. cit., Vol. I, pg. 174.

(2) Feuties (W. J.), 'Two summers'Work in Pueblo Ruins 22. Annual Report of the Bureau of American Ethnology, 1900-1901, Washington, 1904, pgs. 127 y 128. 
Uno de los Huicholes, que acompañaba a Lumholtz en sus excursiones, se detuvo ante un montón, llamado Nutiquaye, el que sabe curar, y cogiendo un poco de hierba y una piedra, después de escupirla, se frotó con ellas los muslos, se las pasó dos veces sobre el pecho y las espaldas, exclamando: "Kemestiquaí!» (Que yo no me canse!), y las depositó sobre el montón.

Ouando los Tepehuanes llevan un cadáver, descansan, junto a cada uno de estos montones, quince minutos, a fin de que el difunto no se fatigue y pueda llegar al término de su larga jornada, a la tierra de los muertos.

Si algunos de estos montículos, como en el caso ya citado, tienen nombres particulares, todos están bajo la protección de la Diosa de las nubes meridionales (1).

Antiguamente, en México, en los montes, sierras $y$ en los puertos por donde pasaban de una parte a otra, los que subían, derramaban sangre do las orejas, quemaban incienso, echaban rosas, de las que cogían por el camino, o amontonaban piedras, como lo continua-

(1) Lumholtz (Carl), Unknown Mexico, New York, 1902, Vol. II, pg. 282.

Religión del Imperio de los Inens 
ron haciendo, bajo la dominación española, los indios que pasaban por los caminos, que van por las sierras contiguas al volcán Popocatepel, en Huexótzinco y en otros lugares. Esta costumbre era especialmente observada por los mercaderes y cargadores (1).

En Yucatán, si el que va caminando, topa con una piedra grande, de las muchas quo se levantaron para abrir los caminos, la revelencia, poniéndola encima una rama y sacudiéndose con otra las rodillas, para no cansal'se (2).

En Guatemala, los indios hacían sacrificios en las puntas de los cerros y en las encrucijadas de los caminos, en unos adoratorios que llamaban mumuz, que había de trecho en trecho on los caminos; on llegando al humilladero, que estaba a la entrada del adorato rio, tomaban unas hierbas, dábanse con ellas en las piernas, escupían on ellas y poníanlas on el humilladero, con una piedra encima. Decían ellos, que esto era cosa saludable, para desechar el cansancio y por lo que lìégo sen-

(1) Torquemada, Monarquia Indiana, Madrid, 1723. Vol. II, pg. 33.

(2) Cogolludo (Diego), Historia de Yucatán, Madrid, 1688, pg. 189 . 
tían fortaleza en las piernas, ofrecían allí algodón, caza, sal, pimientos o de las otras cosas que llevaban (1).

En Nicaragua, en tiempos precolombinos, había carines en los senderos. Los que junto a ellos pasaban, echaban un puñado de hierba, opinando que, haciéndolo así, no se cansaban ni tenían hambre, o que, al menos, no eran tan aquejados de hambre o no se fatigaban, como se fatigarían, si no observasen la antigua usanza (2).

En las cumbres de la hoy desierta sierra de Animas, en el Urugnay, encontró Darwin, carines, que, según sus informantes, eran obra de los antiguos indios (3).

En varios lugares de este capítulo, hemos hecho ya mención de carines, situados en las cumbres de los pasos y sugerido el modo de explicarlos. En las páginas que anteceden, hemos querido juntar aquellos ejemplos, en que puede suponerse, que el fin del rito es arrojar

(1) Román y Zamora, Las repúblicas de Indias, Madrid, 1897, Vol. I, pg. 207.

(2) Bobadilla, Información de los ritos e idolatrias de los indios de Nicaragua en Oviedo. Historia General y Natural do Indias, Vol. IV, pg. 52, Madrid, 1855.

(3) Daruin, (Charles), Journal of researches into the Geology and Natural History, London, 1810, pg. 52. 
la fatiga, encarnada en una piedra, palo a otra cosa semejante, en la cual se ha escupido, con la que se ha frotado las piernas o cualquiera otra parte del cuerpo. En muchos de ellos se menciona claramente este objeto; en otros, nada se dice del móvil del acto, tál acontece en las informaciones que poseemos acerca de los carines observados en el valle de Uthingo (1), entre Ios M'rus (2), en el prinpado mongol de Korko - nor (3) y en Méjico (4). En otros, como entre los Seeds, se nos dice que los carines se levantan ante rocas singulares (5); lo cual nos antoriza a suponer, que dichos montones en nada se diferencian de los que se levantan sobre lugares sagrados y de caya interpretación ya nos hemos ocupado (6), puesto que los pueblos primitivos han tenido por poseedoras de virtudes sobrenaturales, a las rocas y piedras que les parecían extraordinarias, por su forma o tamaño (7).

\footnotetext{
(1) Vide supra, pg. 251.

(2) Vide supra, pg. 251.

(3) Vide supra, pg. 252.

(4) Vide supra, pg. 257.

(5) Vide supra, pg. 250.

(6) Vide supra, pg. 237.

(7) Vide infra, Capitulo $V$.
} 
En cuanto a los montículos que hay en los pasos y en otros lugares de Oorea, parece imposible el no atribuírlos a la misma causa que a la que hemos atribuído los carines estudiados hasta aquí, esto es, al deseo de cegar la fuente de poder maligno, de enterrar al demonio, cuyas maldades se temen. Esto aparece con toda evidencia de los datos que, acerca de los montículos coreanos tenemos y que, prolijamente, hemos expuesto (1).

En efecto, no sólo son peculiares de los montes y caminos, sino, según lo observa un bien informado autor, de todos aquellos lngares en que la tradición señala la existencia de un espíritu maligno (2).

No nos parece necesario el ocuparnos de los montículos que hay a la entrada de preblos hopis y zuñis, ya que el estar dedicados al dios de los muertos, hace que los identifiquemos con los que se construyen en lugares sagrados $o$ en enterramientos (3).

Si los casos apuntados, pueden explicarse en conformidad con la hipótesis general, por
(1) Vide supra.pg. 253.
(2) Vide supra pg. 255.
(3) Vide supra pg. 255. 


\section{Religión DeL IMPERIO DE LOS INOAS}

nosotros propuesta, no por eso dejan de existir algunos carines que, según lo afirman sus constructores, tienen por fin dar reposo a los caminantes, lo cual parece estar on contradicción con la doctrina que, acerca de estos monumentos, hemos deducido de muchos y muy significativos hechos. Mas, quizás, la contradicción es tan sólo aparente. Para disiparla, basta saber a qué atribuyen los primitivos la fatiga, asunto acerca del cual, como ya puede suponerse, no abundan las informaciones. Sin embargo, el gran viajero francés D'Orbigny ha hecho al respecto, observaciones preciosas. Dice, que los Araucanos, cuando se cansan en ol camino, atribuyen el cansancio a un mal espíritu, que ha penetrado en su cuerpo $y$, para hacerlo salir, se sangran las espaldas, brazos o muslos, creyendo que, con la sangre, saldrá el genio de la fatiga y añade que de este modo de pensar participan los Ohiriguanos, $\mathrm{Yu}$ racases $y$ otras poblaciones que habitan al Oriente de la Oordillera de los Andes (1). Lo cual es muy significativo, pues demuestra que no se trata de una idea local, ya que se en-

(1) D'Orbigny (A.), Voyage a l'Amerique Meridionale Paris, 1839-43, Vol. II, pg. 39. 
cuentra en pueblos, que es improbable hayan tenido algún contacto.

Ahora bien, si los primitiros atribuyen la fatiga a un espíritu o poder mágico maligno, no podremos suponer que creen que éste reside en las cumbres de las montañas? ¿ No sabemos acaso (ya que de ello tenemos repetidos ejemplos) que han creído que en las cúspides residen genios irritables y dañinos? En cuyo caso qué cosa más natural que el que atribuyan a éstos la fatiga producida por la ascención, ya que, mientras más se acerca el caminante a la cumbre, más difícil se le vuelve el continuar su ruta $y$ una rez coronada la montaña, el espíritu se dilata, los músculos se llenan de nuevo vigor, a la vista del descenso y ante la convicción de que la mayor dificultad ha sido dominada. $Y$ si es así, $\dot{c}$ no será muy lógico el suponer, dada la mentalidad del hombre no civilizado (que, por motivos que no es del caso analizar, cree que la cúspide de los cerros es la residencia de espíritus mal intencionados) que atribuya a éstos la fatiga experimentada en la subida $y$ que arroje piedras en los lugares, de donde juzga que emana, para impedirle salir 5 enterrarla? $\mathrm{Y}$, si esto es así, muy fácil es explicarse cómo, 


\section{RELIGIÓN DEL IMPERIO DE LOS ÍNOAS}

con el transcurso del tiempo, la evolución de las ideas y la constante repetición del acto, seguido de una misma sensación, la de disminución del cansancio, propia del descenso, se haya olvidado el fin primitivo del rito $\mathrm{y}$ llegado a juzgarse que, al arrojar el guijarro sobre el montón, se echa allí la fatiga. Lo cual era tanto más fácil de que crea el primitivo, cuanto que muchos de sus ritos mágico-religiosos, estaban fundados en la trasmisión del mal de que adolecía a un objeto material, para librarse de él, al mismo tiempo que de éste.

Bien sabemos que todo lo antecedente no es sino hipótesis; mas parécenos que no carece de apreciables fundamentos $y$ que, si no andamos muy equirocados, el arrojar la fatiga, al depositar una piedra sobre un carín, es una modificación más o menos profunda de la costumbre original, según la cual se amontonaban piedras en un sitio, para impedir la emanación de la fuerza mágica o espíritu maligno, que, penetrando en el cuerpo del viajero, hacíale experimentar la sensación del cansancio.

Mas no desconocemos la existencia de otros casos, en que el arrojar piedras ha sido motivado por el deseo de libertarse de los males, en ellas encarnados. Así, en las ceremonias 
descritas en el libro sagrado de la India, Satapatha-Brâhmana, en la Tanda novena, Andaynya primera, Brâhmaña segunda, el sacerdote arroja piedras hacia el Sudoeste o Mirriti, para echar el sufrimiento, encarnado en la piedra y que ésta puede trasmitir (1).

Más significativa para nuestro objeto, es la siguiente usanza escosesa, fa que en el Rito Brahmánico, no existe un carín. En el manantial sagrado de Strathfillan, en Pertshire (Escosia), los que allí acuden, cogen nuere piedras en la fuente $y$, después de bañarse, van a un cerro, que está en la vecindad, en donde hay tres carines, alrededor de cada uno de los cuales dan tres vueltas, arrojando en cada giro una piedra. Si el que se ha bañado, sufría de algún dolor corporal, echa también sobre los carines una parte del restido, que cubría la parte enferma. Con el agua de la fuente, fabrican además, remedios para animales, pero que sólo son eficaces, si se deja sobre uno de los carines, la cuerda, con que, ordinariamente, se ataba al animal (2).

(1) The Satapatha Brâhmaña-acording to the text of the Madhyandina Scool-Translated by Julius Eggeling-The Sacred Books of the East, Vol. XLIII, Oxford, 1897.

(2) Hartland (E. S.), The Legend of Perseus, Vol. II, pgs. 203 y 204, London, 1895. 
266 Religión DeL İMPerio de los INOAS

Con la precedente, se puede poner en parangón esta otra usanza, obserrada en las Antillas, en Santo Domingo. Dos kilómetros antes del célebre santuario de la Virgen de $\mathrm{Hi}$ guej, está una colina, llamada el calvario, y formada por las piedras que los peregrinos, que ran a esta romería, arrojan, las cuales traen desde sus casas, respecto de las que dicen que, como al echar la piedra, se quitan un peso de encima, así, al implorar a la Virgen, se libran de sus sufrimientos (1).

Muy posible es que la explicación do minicana del rito, practicado en el Calvario de Higues, haya sido inventada, para justificar y cristianizar una usanza primitiva, cuyo móvil original fuese distinto del que ahora se le atribufe. Queda, no obstante la costumbre escocesa, en la que parece que las piedras se depositan sobre los carines para libertarse de una dolencia. Mas, aún en este caso, cabe preguntar: ¿no serían más bien los vestidos que se ponían sobre el carín, aquellos en que estaba encerrado el mal, y la piedra, un peso para sujetarlos, e impedir que fuesen llevados

(1) Been, Mayotte, Paris, 1898, pgs. 18 y 19. 
por el viento y se convirtiesen en vehículo de contagio?

El lugar cargado por los males de tantos enfermos, que en él dejaban sus vestidos contaminados, no sería quizás el que se quería tapar, para que las enfermedades que allí contenían, no se propagasen, nó por la dispersión de los baccilos físicos, sino de los inmateriales y suprasensibles?

Sea esto como fuere, estos solos bechos no son suficientes para desvanecer el peso de los numerosísimos ejemplos, que prueban que las piedras se depositan sobre los carines para impedir la emanación de una fuerza nociva, sin que pretendamos que no existan montones, construídos con otras miras. Así, según Doutte, hay montones de piedras en el Sahara, que no tienen otra razón de ser, que la de guíar a los caminantes, señalándoles la ruta (1).

Los Arabes, tienen carines que indican linderos, o que sirven para la caza de las gacelas (2).

(1) Doutte (Edmond), Magie et Religion dans l'Afrique du Nord, Alger, 1909, pg. 426.

(2) Chauvin (V.), Le Jet des pierres au pelerinage de la Mecque, Anvers, 1902, pg. 279. 
El mismo Doutte, nos dice, que en la Kabila se construye uno de estos monumentos, para conmemorar una resolución importante; mas a este carín no se añaden nuevas piedras, una rez la obra terminada (1).

Sabido es que Jacob y Labán amontanaron piedras, en testimonio de su reconciliación (2).

Ouando los Estonianos, de la isla de Oe. sel, so comprometen a alguna cosa de importancia, arrojan sobre un carín, piedras o astillas de madera, para dar mayor peso a la promesa (3).

Según un viejo znlú, los ejércitos invasores amontonaban piedras, para marcar la extensión de sus conquistas (4).

Reflexionando sobre los seis casos antecedentes, se advierte que, si bien es posible que los montícnlos del Sahara, así como aquellos a que se refería el riejo zulú, no tengan otro objeto que el de señalar el camino, o el de testimoniar el arance de un ejército en territorio enemigo, es también muy probable que, habiendo sido erigidos para marcar el sitio en

(1) Doutte (Edmond), Loco cit.

(2) Génesis, Cap. XXXI, versículos 45 a 48.

(3) Andree (R.), Ethnograpische Parallelen und Vergleiche.

4) Dudley Kidd, The essential Kafir, London, 1904. 
que ocurrió una muerte violenta, hayan servido de guía a los caminantes, o de memorial de las victorias conseguidas, pues, como era natural, las tumbas so encontraban, o junto a las rutas, seguidas por las caravanas, o en el área recorrida por el ejército enemigo.

Más especial atención, merecen la práctica estoniana, que debe compararse con la somalí ya estudiada, pues nos revela que aquellos insulares, creen que en el carín reside una virtud superior, que garantiza el cumplimiento de lo que se promete, añadiendo piedras o palos al montón, lo cual está muy de acuerdo con lo que hasta aquí hemos expuesto, respecto a estos monumentos. La añadidura que se hace al carín, es un acto de magia imitativa, para que la promesa sea estable, como la piedra en el carín; y así como no se puede quitar ésta, ya que el que tal hiciere, recibiría, digámoslo así, la descarga de la fuerza mágica, tanto más poderosa cuanto que estaba tapada con el guijarro, del mismo modo no se puede levantar el compromiso allí adquirido. Segín esto, trataríase de un rito, compuesto de una fórmula de magia bien común, la do dar a nna promesa, merced a un acto imitativo, la 
estabilidad $y$ peso de una piedra (1) y de la creencia que, hasta aquí hemos encontrado, ser el fundamento de aquellos carines, on que se hacen añadiduras.

Acerca de los carines conmemorativos de la Biblia, la Kabila $y$ los árabes, nos parece innecesario extendernos. De los segundos, consta que en ellos no se ponen nueras piedras y de los otros se puede suponer, fundadamente, otro tanto. Nada extraordinario es que se amontonen piedras, para rememorar una resolución importante, tanto más, cuanto que el hacinamiento hecho por el patriarca hebreo y su contrincante, parece que fué un rústico $\theta$ improvisado altar.

Estos carines, nos traen a la memoria, la siguiente $y$ curiosísima práctica de Borneo. Entre los Ibans, una de las varias naciones que moran en aquella gran isla, si un hombre ha engañado a otro, en materia grare, mintiendo maliciosamente y su falsedad es descubierta, uno de los engañados toma un palito y lo arroja en un lugar muy frecuentado, diciendo en presencia de otros: "Aquel que no añada

(1) Frazer, The Golden Bough, Vol. III, (The Magic Art and erolution of kings.) 
en este montón de mentirosos (tugongbul) su fra dolores de cabeza». Los demás hacen otro tanto $y$, si el montón llega a ser conocido, todo pasante arroja una nueva vara sobre él, de miedo de los dolores de cabeza que podrían sobrevenirle. Así, el montón crece, llegando a veces, a tener considerable tamaño y siendo conocido por el nombre del mentiroso, es para éste una gran afrenta (1).

Por demás estaría cualquier comentario, ya que es evidente, que aquel que establece la costumbre, fija, mediante un encantamiento, en un sitio determinado, un poder que da dolores de cabeza, a menos que se cubra el sitio, arrojando en él varitas, que lo tengan tapado.

No son de tan fácil explicación, las siguientes usanzas melanesias:

En la isla do Saddle, en el lugar denominado Valuwa, hay un carín, en el que todos los pasantes, que no son del lugar, depositan una piedra. Los naturales dicen que los días se acumulan como las piedras y que aquel

(1) Hose (Charles), and Mac Dongall (William), The Pagan of tribes Borneo, London, 1912, Vol. II, pg. 123. 
que coloca una sobre el montón, pone un día sobre él.

En Pun, en la misma isla, hay un montón de frutas de varias clases. Todo extranjero que pasa, recoge úna en el camino y la arroja en el montón. Tanto este carín, como el anterior, son peculiares de los pueblos en que se encuentran, a cuyos moradores agrada que se observe la antigua usanza, pues demuestra el número de visitantes que ha tenido la población (1).

¿Trátase de genios locales, que es preciso cubrir, para poder pasar? Temerario sería el asegurarlo.

El camino que va de Valuwa a Motlar, pasa entre dos grandes piedras. Los viajeros que van a Valuwa, tocan la piedra de la derecha, diciendo: "Permite que Valuwa esté cerca y Motlar lejos». Los que van en sentido opuesto, hacen otro tanto con la otra piedra, pidiendo hallarse próximos al fin de su jornada (2).

Tócanos ahora ocuparnos en otra clase de carines, que sorprenden y parecen inexplica-

(1) Codrington, The Melanesian, Oxford, 1891, pg. 185.

(2) Codrington, Loco cit. 
bles, cuando, por primera vez, se los examina, puesto que difieren notabiemonte de los hasta aquí estudiados.

Los Basutos, que sienten hambre $y$ ren a lo lejos al humo de un kraal, en donde mora el amigo que van a ver, temiendo que éste haya tenido aquel día más apetito que de ordinario $y$ no encontrar comida a su llegada, se detienen ante uno de los carines, que hay a la vera de los caminos 5 , tomando una piedra, escúpenla $y$ pónenla en el montón, con lo cual creen estar seguros de que, al fin de la jornada, no les faltará el ansiado alimento (1).

En todo el país de los Kafires, se encuentran pequeños montones de piedras, junto a los caminos. Ijus aborígenes, al pasar, depositan una piedra, después de escupir en ella y murmuran una corta oración. Los naturales son muy rarios en la explicación de esta costumbre: a reces, dicen que asegura hallar comida en la próxima rivienda, o que impide que los alimentos se cocinen antes de la lle. gada del huésped (2).

(1) Casalis, Les Basutos, París, 1859, pg. 288.

(2) Dudley Kidd, The essential Kafir, London, 1904. 
Según otros, son estos carines testimonios de que, al salir del Kraal, no intentan abandonarlo, sino que piensan volver pronto a la morada; aseguran también, que al depositar una nueva piedra en el montón, consiguen un feliz viaje (1).

En Bechunaland, los riajeros colocan una piedra entre las ramas de un árbol, o ponen yerba en en el camino, para encontrar qué comer en el próximo kraal (2).

Los Australianos, para que el sol no se oculte, hasta que ellos lleguen a su casa, ponen una piedra en la horquilla de un árbol, situada al Occidente. Lo mismo hacen los Gobos de la tribu de Bahr-el-Ghazal (3).

Cogolludo nos cuenta que, cuando un yucateco caminaba a la puesta del sol y temía llegar de noche al pueblo donde iba, encajaba una piedra en el primer árbol que liallaba, para que el sol no se pusiese tan presto (4).

Posible es que la explicación de algunos

(1) Tleming, Kafraria and its inhabitans London, 1853, pg. 113.

(2) Dudley Fidd, Op. cit.

(3) Frazer (J. G.), The Golden Bough Tol. I, [The Magic Art and the evolution of kings], pg. 318, London, 1913.

(4) López Cogolludo (Diego), Historia de Yucathan, MrCTrid, 1688, pg. 183. 
de estos hechos, sea la misma que la de aquellos carines, en que se espera obtener buena ventura, fácil viaje o reposo; $y$ que se atribuya el exceso de hambre a un mal espíritu, residerte en el sitio, o más bien, que deseando llegar pronto a un lugar, se trate de impedir los retrasos que puedan causar los genios mal intencionados del camino, sepultándolos bajo los montones de piedras.

Mas esta interpretación, no es aplicable a lo observado en Bechunaland, en Australia, entre los Golos y Mayas, acerca de los cuales opina, con mucha razón, Frazer, que los actos de éstos son de magia imitatira, fundándose, para afirmarlo, en la práctica australiana, de señalar las horas del día, colocando guijarros en los árboles, a diferentes alturas, según la eleración del sol (1).

Dada la importancia que tienen las apachitas en la religión del Perú y el lugar que ocupan en todos los libros, en que del Imperio de los Incas se trata, hemos querido que la enumeración antecedente, sea lo más completa posible, sobre todo, dada la rariedad de opiniones de los autores, sobre el fundamento

(1) Frazer, Loco cit. 
de esta clase de monumentos $\boldsymbol{y}$ el no encontrar nosotros ninguna de las teorías, que nos eran conocidas, satisfactorias.

Ahora, basados en el considerable número de hechos acumulados, podemos, con alguna probabilidad de acierto, exponer breremente el porqué del rito, segúu el cual todo pasante arroja piedras en un lugar determinado, $\boldsymbol{y}$ las rariantes $y$ modificaciones que ha sufrido esta sencilla usanza, con el andar de los tiempos y la erolución de las ideas religiosas.

Nacida en aquellas épocas primitivas, en las que el concepto de diriniład era aún muy oscuro $y$ en las que andaban confundidas las nociones de magia $\mathbf{y}$ religión, $\boldsymbol{y}$ cuando todaría 110 se había marcado netamente la línea que separa lo santo de lo impuro, y ambas entidades se encontraban aún en embrión en la idea de sagrado; la práctica de amontonar piedras en un sitio, estaba basada en el deseo de mantener cubierta la fuerza mágica, cuyos misteriosos efectos se temía.

En aquellos pueblos, en los que el progreso se rerificaba; en los que, por obra de clases dirigentes, dotadas de actividad $\mathrm{y}$ talento, las ideas abstractas y los conceptos metafícicos iban penetrando en las masas popula- 
res, la antigua costumbre, según los casos, trocóse en un acto de defensa, lapidación del demonio, o en un tributo de reneración y respeto a un poder, que, así como es benigno con aquellos que le son gratos, podía castigar $y$ herir a aquellos que le habían irritado. O bien, coincidiendo el acto de arrojar la piedra o palo con una disminución de fatiga, cuando ya no era corriente el atribuír un espíritu a las montañas o cuando la creencia en este genio sólo ocupaba un lugar secundario, olvidóse, más o menos completamente, de la noción primitiva y juzgóse que la fatiga disminuía, arrojando la piedra, y supúsose que tál acontece, porque la piedra llevaba encarnada el cansancio.

Mas no de un salto, pasó la Humanidad de las vagas y hermosas concepciones primeras, a las precisas y nítidas ideas de los pueblos modernos: entre ambos extremos encuéntranse mil estados intermediarios. Así, cuaudo la vaguedad de las ideas primitivas ha desaparecido, para dar plaza al antropomorfismo más o menos exclusivo, juzgóse que no sería inútil precaución, tratar de obten píritu, residente en el luggar, on que se arrojaban las piedras, por si la tapa que se lo po- 
ne, o la piedra, con que trataba de amedrentársele, no fuesen suficientes, entónces procúrase establecer entre el genio y el viajero, cierta consanguinidad y parentesco o de entregarle una parte de sí mismo, para que con ella se distraiga $y$ entretenga, mientras el pasante se aleja y se pone al abrigo de sus ataques. Cuando así se juzga, es cuando se escupe en la piedra o se la pone en contacto con la persona, frotándosela al cuerpo o empleando algún procedimiento semejante.

Si se cree que en el sitio reside un espíritu poderoso; si, teniéndolo por peligroso $\mathbf{y}$ maligno, se juzga que, dirigiéndose a él con las debidas fórmulas, se puede obtener su auxilio, ¿no será natural el que, tomando las convenientes precauciones para acercarlo, esto es, impidiendo su inmediata emanación, acudan a él los que tál juzgan, rogándole les conceda tal o cual favor? Proceder de esta manera es obrar muy on conformidad con la mentalidad primitiva; y así se explica cómo estos lugares, originariamente de terror, lleguon a recibir cierta adoración y culto.

La sencillez de esta usanza, la facilidad para practicarla $y$, sobre todo, su poco costo, han sido causas para que perdure y se perpe- 
túe en pueblos, en el que el estado religioso, de que se originó, ha desaparecido completamente, y en que aún el rulgo posee nociones de teodicea, incompatibles con proceder tan primitivo, como es el de tapar o lapidar a un espíritu, para librarse de sus ataques. Sólo merced a estas cualidades, el rito en referencia, ha podido sobrevivir en épocas de evolución adelantada, sin ser perseguido y prohibido, por los ministros de cultos más avanzados.

Así, las apachitas peruanas, prohibidas por el Segundo Concilio Provincial, reunido en Lima, hanse conservado hasta nuestros días, $\mathrm{y}$ aún en numerosas ocasiones, al montón pagano se ha añadido una cruz y convertídose en lugar de devoción (1).

(1) En el antiguo camino de a caballo, que de Quito conducía al santuario y pueblo de Guápulo, existía, hasta hace algunos años, una cruz, a cuyo pie los peregrinos arrojaban piedras. La tradición, según nos fué narrada, relacionaba este sitio con cruentas penitencias de un obispo muy devoto de la Virgen del lugar, quien se disciplinaba al pie de la cruz, hasta bañar la tierra con su sangre. Ignoramos si exista aún la cruz; seguramente su importancia habrá disminuido a causa de la nueva carretera, que pasa bastante apartada de dicho lugar. Aũos más tarde, cuando lo visitamos, la cruz habia desaparecido, carcomida por la humedad y el tiempo; veíase tan sólo el pedestal, que era de piedra, y algunos guijarros amontonados. En Elén-pata, cerca de Guano, (Provincia del 


\section{Llegó a tal punto esta singular amalga-} ma, cuando, por móviles fáciles de comprender, se quería hallar restos de cristianismo, o por lo menos, creencias monoteístas entre los aborígenes del Perú, que autor tan perspicaz, práctico conocedor de las idolatrías de los indios $y$ de las supercherías de que éstos se valían, para perseverar en ellas, como

Chimborazo - Ecuador, hay en el camino de Penipe, una gran cruz, que es una apachita muy renerada.

En Alacaú, (Guano) hay una cruz de piedia, de aspecto muy antiguo, que es una apachita famosa, y junto a ella, hay un trilito, en que los pasantes depositan sus ofrendas. Rumicruz de Alacaú, tiene su fiesta anual muy concurrida.

"En los pasos peligrosos $y$ áifíciles, los riajeros encuentran a lo largo del camino, grandes montones de piedras, depositadas una a una por los indios, para que no les suceda ninguna desgracia. Estos montones, existen en los puntos culminantes del camino, que de Cuenca va hácia el Norte, en el temible paso del Azuay, llamado "Tres cruces" o Quimsa cruz, y en el camino de Cuenca al Naranjal, en el sitio llamado Cajas. Junto a estas piedias, hay también pequeñas cruces, hechas con la paja del páramo; la usanza pagana se ha cristianizado, pero la intención que guia a las gentes se conserra la misma.- Rivet, Le Christianisme des Indiens de la Republique de l'Equateur.-L'Antropologie, Tol. XVII, pg. 90, París, 1906.

En Salta (Argentina) existe también un lugar llamado Tres-Cruces, en donde hay una cruz, y en ella, en lugar de depositar piedras, arrojan los viajeros crucesitas hechas con dos palitos atados con un hilo. Ambrosetti, Supersticiones y Leyendas Argentinas, Buenos Aires, 1917, pgs. 180-183. 
el Visitador Arendaño, no raciló en afirmar, desde la Cátedra Sagrada, que los antiguos hechiceros, sin conocer quién daba fuerza a los caminantes, llamaron a tan benigno ser, Apachec, y que identificase esta flamante dirinidad con el Dios desconocido, cujo altar encontró San Pablo, y que el Apóstol identificó con Jesucristo, criador del cielo y de la tierra, y aseverase que, por esta razón, los Españoles pusieron cruces en las Apachitas, para que los indios las adorasen $y$ rererenciasen, cuando, junto a ella, transitaran (1).

(1) De la misma manera los hechizeros, no conocieron, ni supieron quien era el Dios que ayudaba y daba fuerzas a los caminantes, que lleuan cargas sobre sus hombros, $y$ sin conocerlo lo llaman Apachecc, que quiere dezir el que ayuda a lleuar la carga, y a este Apachecc, le ofrezian coca mascada, o mayz mascado, plumis, o calçados viejos, o las guaracas con que se atan la cabeça, o le ofrezían rna piedra pequeña, $y$ hasta agora se ven en los caminos estos montones de piedras ofrezidas a esta Huaca no conocida.

Oydme con atención; $y$ sabréis quien es este Apachecc, que dã las fuerzas para lleuar las cargas. Sabed hijos, que quando el Apostol San Pablo andaua predicaudo, $y$ enseñaua a los hombres, qne Jesu Christo nuestro Señor era Dios verdadero, llegó a vna ciudad llamada Aeropago, $y$ vió en el templo vn altar en que estauã escritas estas palabras: Ignoto Deo: al Dios no conocido. $Y$ entonces el Apostol dixo: Este Dios que rosotros no conoceis es el que yo os enseño, este es Jesu Christc nuestro Señor, este es el que crió el cielo, y la tierra. De la misma manera hijos, este Apachecc, que ruestros abue- 
Boman encontró en Susques, Puna de Jujuy, una apachita, junto a la cual se había constraído una capillita de adobes, en la que estaba la imagen de un Santo, y, según el guía que le acompañaba, los apachitas pueden estar dedicados a un Santo o a Pachacama (1).

Conocemos un caso análogo en el camino, por donde antiguamente, se iba de Pomasqui a San Antonio (Provincia de Pichincha). En una vuelta de la ruta, encontrábase una capilla de la Virgen, en cuya capilla, muy ordinariamente, ardía una lámpara; todos los viajeros arrojaban allí guijarros.

Si algo pudieran enseñarnos estos ejemplos, fácil sería multiplicarlos, indefinidamente. Basten los anotados, para demostración de la supervivencia del uso pagano y de su forzada adaptación al Oristianismo, debida no sólo a

os no conocieron. Este que dá fuerzas para lleuar las cargas es Jesu Christo nuestro Señor, y por esso los Españoles han puesto en estos Apachitas la Santa Cruz, ya las habreis visto, paraque quando fueredes caminando, y llegaredes a estos Apachitas, adoreis la Santa Cruz en que murió Jesu Christo nuestro Señor, y le pidáis que os dé fuerzas y os ayude para lleuar las cargas. Avendaño, Sermones en Quichua y Castellano, Vol. 1, fol. 55 v. y sig., Lima. 1649.

11) Boman, Antiquites de la Región Andine de la Republiquo Argentine, París, 1908, pg. 424. 
ardides de los indígenas, arraigados en sus viejas tradiciones, sino más todavía a un indiscreto celo de parte de muchos earopeos y criollos, y del cual son buena muestra las aserciones de Arendaño, poco há citadas.

Encontrábanse, ordinariamente, las apachitas en los caminos, al fin de las subidas, $y$ eran montones de piedra, en los cuales los caminantes arrojaban coca o maíz mascado, plumas de varios colores, hondas, que algunas parcialidades empleaban en el tocado, ojotas viejas, trapos, soguillas o manojillos de la paja del páramo, llamada ichu, y, más fre_ cuentemente, una piedra, a veces, de proporciones considerables, que, en alguna ocasión, traían en hombros un buen rato (1).

(1) Quando suben algunas cuestas o cerros, ponen en el carín) coca, o maíz mascado.... ojutas... o la Huaraca, o unas soguillas, manoxillos de hicho, o paja o ponen otras piedras pequeñas encima y con esto dicen que se les quita el cansancio. A estos montones, suelen llamar Apachitas. Arriaga, Extirpación de la Idolatria, Lima, 1621, pg. 37.

Al pasar por las Apachitas y algunas otras guacas, les solian echar por ofrenda coca mascada, plumas de varios colores, y cuando no se hallaban con otra cosa les arrojaban el calzado viejo, un trapo o una piedra, y destas piedras así ofrecidas vemos hoy muchos montones en los caminos. Hacían esta o frenda cuando iban caminando, porque las dichas Guacas los dejasen pasar, y les diesen fuerzas; y así decian que los cobraban con esto y cuando otra cosa no tenían les daban otra 


\section{Religión del Iuperio de los Inoas}

\section{Los moradores de la Puna de Jujuy, nun- ca dejan de hacer una oferta en las apachitas,}

ofienda tan ridicula como las referidas, y era que arrancandose las pestañas o cejas les ofrecían. Cobo, Historia del Nuevo Mundo, Sevilla, 1894, Vol. IV, pgs. 82 a 85.

Otros quando van camino echan en los cerros, o Apachitas, o rimeros de piedras, calçados viejos, coca, maiz mascado, plumas y otras cosas, pidiendo les dexen passar en saluo, y les quiten el cansancio. Avendaño, Sermones en Quichua y Castellano, Lima, 1649, Vol. II, ff. 33.

\section{CAP. XXI.}

De lo que hazian los Indios, quando caminauan, y las cosas que adorauan.

Cosa fue muy usada en todo el Piru, adorar los Indios, cerros, piedras, peñascos, arboles, manantiales y lagunas, $\mathrm{y}$ algunas, y qualquiera cosa notable, que en los caminos se encontrauan, y a cada cosa destas ofrecian sacrificios. En este pueblo de Copacabana, que fué cabeça de idolatria, $y$ donde mas se ofendió a Nuestro Señor, por ser grande los ritos, y supersticiones que en el se hallaron, vuo gran númro de Apachetas, que para declarar que sean, se a de notar, vsauan los Indios, y oy en muchas partes, no lo an oluidado mnchos, y en particular los viejos, que quando van camino, echan en lo alto de algún cerro, o encrucijadas, algunas piedras, donde halla algun monton dellas, $y$ antes de llegar a semejantes lugares, van con algún temor, y deuoción, pidiendo al cerro fauor, y passaje próspero. A estos promontorios, y rimeros de piedras llamauan Apachetas, y suelê ofrecer el calçado viejo, (que llamaun ellos ojotas/, coca plumas y otras cosas ridiculas, y quando mas no pueden, echan vna piedra, $y$ la suelen lleuar vn buen rato en hombros, hasta llegar al lugar donde se á de poner, $y$ todo esto que echaman era ofrenda para pedir nueuas fuerças al demonio. Yera tanta la ceguera destos miserables Indios, que por semejante acto creyan, que cobrauan aliento, 


\section{como sus antecesores precolombinos; mas em- plean, con este fin, muy a menudo, aguardien-}

y vigor, y muchos estã tadavia en esta ceguera. Deste rito y cerimonia, hace menciõ el Concilio Limense segundo, parte 2, cap. 29.

Por todos los caminos del Piru, y en particular de los de la sierra, se hallan grandes rimeros de piedras ofrecidas al demonio. Ramos Gavilán, Historia del Santuario de Copacabana, Lima, 1621, pgs. 104 y sigts.

Los Serranos vsan quando van camino echar en los mismos caminos, o encrucijadas, enlos cerros, o en rimeros de piedras (que según ya queda dicho se llaman Apachitas) o en las peñas, $\mathrm{y}$ cueuas o en sepulturas antiguas calçados viejos, plumas, coca mascada, o mayz mascado, y otras cosas pidiendo que los dexen passar en saluo, y les quiten el cansancio del camino, y les den fuerças para caminar. "Confessionario para los Curas de Indios.-Instrución Lima 1585.-Fol. 1. Núm. 8.

Si ban caminando algun viaje largo ban comiendo coca (que son hojas de un árbol mediano que se coge en los Andes) y en llegando a alguna abra que llaman Apachita de donde se descubre otra tierra en aquel lugar offrecen coca que lleban en la boca y los que no la comen offrecen lo que tienen como es alguna macorca de maiz copa que son chaquiras, oro y plata y el que no tiene nada desto ofrece una piedra, o leño, $y$ guardan esta ceremonia con tan gran rigor $y$ exacción que no se atreueran a pasar adelante de la Apachita sin auerla hecho, por que de lo contrario tienen por cosa cierta que no bolberan por aquel camino y que quando quieran la apacheta que adoran por huaca no los dexara passar. Oliva (Anello), Historia del Perú.-Lima 1895, pg. 132».

En estos $y$ otros tiempos, i semejantes caminos, guardan por el mesmo fin i respeto una ceremonia luciferina, por que tienen algunos cerros i piedras conocidamente a donde reparan i toman huelgo; alli azotan los pies cou paja, y de la coca que llevan para comer ofrecen aquel lugar, arrojandolo en el aire 


\section{te, que no conocían, antes de la Conquista, con el cual asperjan el montón, cuando en él}

para del todo despedir el cansancio i tomar nueras fuerzas para el trabajo.

Atienza (Lope ${ }^{-}$de).-Compendio historial del estado de los indios del Piru.-1571-1574.

Quando iban de camino, echaban en las encrucijadas, i en los cerros, calçado viejo, Plumas, coca mascada 5 alguna Piedra, como por ofrenda, para que puedan pasar $y$ cobrar fuerzas.-Herrera, Historia General de los Hechos de los Castellanos, Decada Quinta, Madrid, 1728, pg. 90.

(Los indios) aun hoy (mediados del siglo XVIII) ofrecen como víctima siempre que pasan, para facilitar el transito alguna pequeña piedra en la cima del cerro donde ran formando rarios competentes montones. Merizalde y Santisteban, Relación Histórica Política y Moral de la ciudad de Cuenca en Tres tratados de América, Siglo XTIII, Colección de libros raros o curiosos qne tratan de América, Tol. XI, pg. 65, Мadrid, 1890.

Musters (George Chaworth), Notes on Bolivia to accompany Original Maps. The Journal of the Royal Geographical Society, Vol. XLVI1, London, 187\%, pg. 211.

Nordenstiold (Erland), Travels on the Bounderies of Bolivia and Argentine. The Geographical Journal, Tol. XXI, pg. 518, London, 1903.

Forbes (David), On the Aymara Indians, of Bolivia and Peru (The Journal) of the Ethnological Society of London Vol. II, pg. 235, London, 1870.

Marcoy, Toyage de l'Ocean Atlantique a l'Ocean Pacifique a travers l'Amerique du Sud. Le Tour du Monde, Vol VI, pg. 277, Paris, 1868.

Heddel, Toyage dans le Nord de la Bolivie et dans les parties roisines du Perou, París, 1853.

Ambrosetti, Supersticiones 5 Lejendas Argentinas, Buenos Aires, 1917, pg. 180 a 183 
no fijan una banderita, formada por un palo, al cual atan un poco de lana roja, con la que adornan también a sus ganados, en honor de Pachamama (1).

Las piedras que añaden a estos carines, pesan, en ocasiones, hasta 10 kilogramos $y$ no es raro que las lleven desde distancias nada insignificantes (2).

En otras partes del antiguo Perú, las apachitas están siempre adornadas con flores frescas, que los caminantes toman en el camino y colocan en el carín (3).

En algunos altos, en tiempo de su gentilidad, los Peruanos colocaban, en los montones de piedras, flechas ensangrentadas $y, d \theta$ vez en cuando, pedazos de oro, de plata, o cabellos (4).

(1) Boman, Antiquités de la Region Andine de la Republique Argentine etc., París, 1908, pg. 487

Nordenskiold (Erland), Travels on the Bounderies of Bolicia and Argentine. The Geographical Journal, Vol. XXI, pg. 518.

(2) Boman, Op. cit., pg. 487.

(3) Marcoy, Vosage de l'Ocean Atlantique a l'Ocean Prcifique a l'Amerique du Sud. Le Tour du Monde, Vol. VI, Paris, 1862, pg. 227.

(4) Cada rez que sobian algun puerto de niere o frio, en las cumbres tenian un gran montón de piedras, como por altar $y$ en algunas partes puestas alli muchas ensangrentadas 


\section{RELigión DEL IMPERIO de LOS INCAS}

Esperaban, observando este rito, librarse de la fatiga y obtener nuevo vigor, para continuar el viaje (1). Mas no sólo esto creían, ya que al acercarse a los lugares, en que había un monumento de éstos, $y$ a los que tenían tanto respeto, hay autores que afirman que les rendían adoración (2) e iban con gran silencio,

saetas, y alli ofrecian de lo que llevaban. Algunos dejaban alli pedazos de plata, otros de oro, otros pelos de las pestañas, otros de las cejas, otros de algunos cabellos. Las Casas, De las Antiguas gentes del Perú, Madrid, 1892. pg. 99.

(1) Acosta (J.), Historia Natural y moral de las Indias, Serilla, 1590, pgs. 312 a 316.

Los riscos y quebradas hondas, los altos y cumbres de los cerros y collados, que llamaban Apachitas: adoraban estos lugares diciendo que cuando acababan de subir la cnesta arriba y llegaban a lo alto descansaban alli de la subida. Cobo; Historia del Nuero, Mundo Serilla, 1890, Vol. III, pgs. 343 a 346.

Id. Vol. IV, pgs. a 82 a 85 y 86 a 89.

Arriaga, Extirpación de la Idolatría, Lima, 1621, pg. 37. Tillagomez, Carta Pastoral de Exhortación contra las idolatrias del Arzubispado de Lima, Lima, 1649, pregunta 20.

Avendaño, Sermones en Quichua y Castellano, Lima, 1649, Vol. I, fol. 55, Vol. II, fol. 33.

Ramos Gavilán, Loco cit.

(2) Suelen también adorar unos montones de piedras.... y los llaman Apachita. Bertonio, Confesonario muy copioso en dos lenguas Aymara y Española, Juli, 1612, pg. 250.

Cobo, Historia del Nuevo Mundo, Sevilla, 1890, Vol. III, pgs. 343 a 346 Apachita. Montón de piedras adoratorios de caminantes. Diego Conzález IIolguín, Tocabulario de la longua general del todo el Perú llamada lengua qquichua o del Inca, En los Reyes MDOVIII. 
para no irritar a los espíritus del lugar y sufrir la furia del granizo y del viento (1). Esta creencia ha perdurado hasta nuestros días, y aún hay arrieros en el Ecuador que, al atraresar una cima, van con religioso silencio, para no encolerizar a los vientos.

Según Nordenskiold, hay pasos por los cuales aseguran los indígenas que es imposible transitar, sin hacer una ofrenda, $y$ dormir junto a uno de estos monumentos, dedicados a Pachamama: tiénenlo por muy peligroso (2).

Los actuales moradores de la Puna de Jujuy, piden a estos hacinamientos, buena ven-

(1) Tenian por costumbre caminar por alli (por las Apachitas) con gran silencio; porque dicen que si se hablan, se enojarán los vientos $\Sigma$ echarán mucha nieve y los matarán. Las Casas, Antiguas gentes del Perú, Madrid, 1892, pg. 99.

Observando al mismo tiempo (al acercarse a las apachitas) notable silencio para no ser sentidos y dar con el bullicio motivo a la furia del granizo y nevada. Merizalde y Santisteban, Relación Histórica, Política y Moral de la ciudad de Cuenca. Tres tratados de América. Siglo XVIII, Colección de libros raros o curiosos que tratan de América, Tol. XI, Madrid, 1891, pg. 65.

Acosta, Loco cit.

Cobo, Op. cit., Vol. IV, pgs. 82 a 85 y 86 a 89.

Avendaño, Op. cit., Vol. II, f. 33.

Ramos y Gavilín, Loco cit.

(2) Nordenstiold, Travels on the Bounderies of Bolivia and Argentine. The Geographical Journal, Vol. XXI, London 1903,.pg. 518.

Religion del Imperio de 108 Incas 
tura y la fórmula con que los invocan y cuya moderna data se evidencia por sus muchos españolismos, es según Boman:

Tate Apachita, caipucamillmahuan caiojacochachur ospedastatike. Tanarpamay tucui diligenciaype. Padre Apachita con esta lana colorada te hospedo. Ven a ayudarme en todos mis trabajos (1).

Mas no sólo había apachitas en las cumbres de las montañas, por donde pasaba una ruta, sino también a lo largo de los caminos I en las encrucijadas (2) 5 , lo que es más significativo, en tumbas $y$ en otros lugares sagrados (3). Así, sabemos, por Calancha, que

(1) Boman, Antiquités de la Region Andine de la Republique Argentine, París, 1908, pg. 487.

(2) Cfan quando vau camino, echar en los mismos caminos o encrucijadas, en los cerros y principalmente en las cumbres que llaman Apachitas, calzados viejos y plumas, coca mascada... y quando no pueden mas siquiera una piedra, $y$ todo esto es como ofrenda para que les dexen passar $y$ les den fuerças. Acosta, Historia Natural $y$ Moral de las Indias, Sevilla, 1690, pgs. 312 a 316.

Tenian hechos grandes montones de piedras, así en los dichos Apachitas como en las llanadas 5 encrucijadas de los caminos a los cuales también hacian reverencia y ofrendaban. Cobo, Historia del Nuero Mundo, Sevilla, 1890, Vol. III, pgs. 343 a 346.

Ramos Gavilán, Loco cit.

(3) Así mismo era por ria de salutación el sacrificio ligero que en el capitulo precedente queda dicho que ofrecían 
junto a la piedra Alecpong, que era adorada, había un carín (1); y la usanza de amontonar guijarros sobre el lugar, en que ha acontecido una muerte trágica, se conserva hasta hoy (2); de ello podrían citarse muchos ejemplos en la Sierra del Ecuador. Así mismo, escupían coca y maíz mascado, u otras cosas parecidas, en grandes piedras hendidas (3).

Cuando la cabeza colosal de Tiahuanaco, que ahora está en el Mruseo de la Paz, se hallaba en Collo-Collo, los arrieros, al pasar, le arrojaban un puñado de lodo, para defenderse de las inflencias nocivas de la estatua (4).

a las Apachitas, cuando por ellas pasaban, a las sepulturas y a otros adoratorios, arrojíndoles Coca mascada, Maiz y otras cosas, pidiéndoles les lejascn pasar en paz, les quitasen el cansancio del camino y diesen tuerzas para acabarlo. Cobo, Historia del Nuevo Mundo, Vol. IV, pg. 86.

(1) Calancha, Chronica Moralizada, Vol. I, Barcelona, 1653, pg. 553.

(2) Musters (George Charwcrth), Notes on Bolivia accompany Original Maps. The Journal of the Royal Geographical Society, Vol. XLFII, pg. 211, London, $187 \%$.

(3) Si quando ran camino an echado, o echan en las cumbres altas, o apachetas donde llegan, o en piedras grandes hendidas coca mascada, o maíz mascado, o otras cosas escupiéndolas, o pidiéndoles que les quiten el cansancio del camino. $\mathrm{ri}$ llagómez. Carta pastoral de extirpación de las idolatrias del Arzobispado de Lima, Lima, 1640, pregunta 20.

14) Tiener, Perou et Bolivie, Paris, 1880, pg. 420 , 


\section{ReLigión del IMPERIO DE LOS INCAS}

Más curioso es aún el sacrificio que los súbditos de los Incas, hacían junto a los apachitas, arrancándose pestañas o cejas, $\mathbf{y}$, poniéndolas junto a los labios, las soplaban en dirección al sol, como tributo a los espíritus del lugar, a las montañas, a los vientos, o a sus dioses mayores, tales como el Sol $\boldsymbol{y}$ el Trueno (1).

En ciertos lugares de la Sierra del Ecuador, los indios para conseguir el faror de la montaña, hacen un nudo de paja (2).

(1) Otra ofrenda no menos donosa rsan que es tirarse pestañas, o cejas, $j$ ofrecerlas al Sol $y$ a los cerros y apachitas, a los rientos o a las cosas que temen. Acosta, Historia Natural $y$ Moral de las Indias, Sevilla, 1590, pg. 316.

Otros se quitan las cexas $y$ pestañas, $y$ las ofrencen al Sol, y a los cerros, y al trueno. Avendaño, Sermones en Quichua y Castellano, Lima, 1649, Vol. II, f. 33.

De otra ofrenda no menos donosa rsauã estos Indios, quãdo passauan por los Apachetas, que era tirarse de las pestañas o cejas, $y$ poner lo que dellos arracauan junto a la boca alçado el rostro al Sol, y con rn soplo arrojarlas en alto, ofreciéndolos a los cerros, o a los Apachetas, o a aquellos Dioses, que en mayor veneración tenian. Lamos y Gavilán, Historia del Santuario de Copacabana. Lima, 1621, pg. 104.

Forbes, On the Aymara Indians of Bolivia and Peru (The Journal of the Etnological Society of London, Tol. II, pg. 283, London, 1870.

(2) Rivet, Etude sur les Indies de la Region de Riobamba, Journal de la Société des Americanistes de Paris n. 8. Vol. I, Paris, 1903, pg. 78. 
Para formarnos cabal idea de lo que eran los apachitas, será bueno recordar aquellos casos particulares, mencionados por los antiguos cronistas, comenzando por los que se encontraban a la salida del Ouzco, que nos son conocidos, merced al catálogo de las huacas de esa ciudad, hecho por Ondegardo, y que, gracias a Oobo, ha llegado hasta nosotros.

Comenzando por Antinsuyo, encontramos que la tercera huaca del primer ceque, era Chiripacha (chiri $=$ frío, pacha $=$ tierra, esto es, chiripacha = tierra de frío), que estaba al principio del camino de Collasuyo (?), y a la que sacrificaban los pasantes, para tener buen viaje (1).

La décima del segundo ceque de la misma dirección, apellidada Macaycalla (macay $=$ pegar, aporrear, kallay = principiar), era un paso entre dos montones (2).

(1) La tercera Guaca era una piedra grande llamada Chiripacha, que estaba en el principio del camino de Collasuyu; ofrecianle cuantos pasaban por dicho camino, porque les sucediese bien el viaje. Cobo, Historia del Nuevo Mundo, Sevilla, 1890, Vol. IV, pgs. 6 a 47.

(2) La décima se llamaba Macayealla: era un llano entre dos cerros, donde se pierde de vista lo que está destotra parte y se descubre la otra de adelante, y por sola esta razón lo adoraban. Cobo, Loco cit. 


\section{ReltGión del Inperio de los Incas}

La novena guaca, del tercer ceque de Antinsuyo, era Yuncaycalla (yuncuy $=$ calentar, kallay = principiar, esto es: yuncaycalla principia a calentar), especie de puerta, desde donde pierde de rista al Ouzco, aquel que va hacia Chita y en la cual había guardianes, que vigilaban a los que entraban y salían de la ciudad. Ofrecíanle coca los viajeros (1).

La séptima del sexto ceque, de la misma dirección, era, como la anterior, el lugar de donde se dejaba de ver al Cuzco, y llámanla Curavacaja (korpachaj =el que hospeda). Había allí un león muerto, cuyo origen, desgraciadamente, ignoramos (2).

Cachicalla, séptima huaca del octavo ceque de Continsuyo $($ cachi $=$ sal, kallay $=$ principiar, esto es, principia la sal), era un páso entre dos montes, en donde los caminantes

(1) La novena Guaca se nombraba Yuncaycalla: es una como puerta donde se ve el llano de Chita y se pierde la vista del Cuzco; allí había puestas guardas para que ninguno llevase cosa hurtada. Sacrificábase por los mercaderes cada vez que pasaban, y rogaban que les suscediese bien en el viaje, y era coca el sacrificio ordinario. Cobo, Loco cit.

(2) La sétima se decía Curaracaja, es un altozano, camino de Chita, donde se pierde de vista la ciudad, y estaba señalado por fin y mojón de las Guacas deste Ceque. Tenían alli un León muerto y contaban su origen, que es largo. Cobo, Loco cit. 
hacían el sacrificio acostumbrado en semejantes sitios (1).

La sexta huaca del mismo camino y del octavo ceque, era Mlascutcurco, mascay $=$ buscar, ta $=$ partícula de acusativo, orko $=$ cerro; esto es: a la busca del cerro), lugar de dondo se perdía de vista el Cuzco (2).

La décima huaca del ceque de Continsuyo, llamábase Cavadcalla o, más probablemente, Korpachaj (el que hospeda). Era un paso entre dos montes (3).

$\mathrm{Y}$ principio de los montes (Urcoscalla), orko $=$ cerro, kallay $=$ principiar $)$ decíase el sitio, de donde dejaban de ver la ciudad los que se alejaban por la ruta de Obinchaysuyo, y era la novena huaca del octaro ceque de Ohinchaysuyo (4).

Quizás eran también apachitas aquellos

(1) La sétima Cachicalla, es una quebrada entre dos cerros a modo de puerta no le ofrecían otra cosa que la coca que echaban de la boca los que pasaban. Cobo, Op. cit.

(2) La sexta, Mascataurco, es un cerro donde se pierde Ia rista del Cuzco por este Ceque. Cobo, Loco cit.

(3) La décima cuarta Cavadcalla? era una como puerta entre dos cerros que está hocia Guacachaca. Cobo, Loco cit.

(4) La novena Guaca se decia Ĺroscalla. Era el lugar donde perdian de vista la ciudad del Cuzco los quo caminaban a Chinchaysuyu. Cobo, Loc. cit. 
lugares sagrados, llamados Nan y Uxi, de que fa hemos tratado anteriormente (1).

La costumbre de depositar piedras a la salida de una población, ordinariamente, en el lugar en donde se la pierde de vista, asociada con la usanza española de erigir cruces en estos lugares, ha subsistido en más de una región del antiguo Tiahnantinsuyu.

Así, en Susques has cuatro apachitas, alrededor del pueblo, correspondientes a los cuatro puntos cardinales (2).

Además de los carines enumerados, ba llegado también hasta nosotros, la fama de Oontur Apacheta (carín del cóndor), notabilísimo apachita, situado cerca de Sicasica, en país aymara (3), 5 la de Mollo Ponco (mollo = concha, colorada; ponco = puerta; esto es $=$ puerta de la concha colorada), paso que conduce a Potosí, renombrado adoratorio indígena (4).

(1) Vide supra, pg. 26.

(2) Boman, Antiquités de la Región andine de la Republique Argentine, París, 1908, pg. 429.

(3) $Y$ el mas famoso de todos (los montones de piedras), llaman Contor Apachita... no está lejos de Sicasica. Bertonio, Confesionario muy copioso en dos lenguas Aymara y Española, July, 1612, pg. 250 .

(4) Mollo Ponco, que es la entrada de Potosi muy famoso (adoratorio) entre todos los Indios. Arriaga, Extirpación de la Idolatría, Lima, 16:21, pg. 5.

Adoran a Mollo Ponco. Bertonio, Loco cit. 
Apachita es, según Middendorf, una forma de acusativo: apachista o apachijta, usado hoy, como el nominativo de un sustantivo simple. $Y$ « como al llegar a la cima de una cuesta, suele descansarse, se llama cada lugar de descanso, $y$ aún el lugar del descanso, apachita» (1); $y$ de allí se originan las expresiones apachitata ruras $=$ hacer un descanso; apachitay $=$ descansar $;$ apachita-icuy $=$ descansar $y$ hacer colación ; apachitaicusunchis $=$ descansemos y refresquémonos (2), formas, probablemente modernas, ya que no se las encuentra en los antiguos diccionarios.

En quichua, las roces apay o apau, significan llerar; apac, el que llera, cargado, o sobre sí o en las manos; apachi, hacer llevar, enviar; apachyg, el enviado; apachicu, enviar regalos; apachina, que ha de ser enriado, el enviadizo; apachini, dejar o hacer llevar; apachipu, enviar algo a alguien, volver a enviar, derolver; apachitamuy, mandar a alguien para dejar algo de paso en un lu-

1) Middendorf: Worterbuch des Runa-Simi oder Keshua Sprache, Leipzig, 1890, pg. 52.

(2) Id. id., Loco cit. 


\section{Religión deL IMPerio de los InOAS}

gar (1). Lo cual nos induce a creer que, primitivamente, la voz apachita, equivale a el enviado (apachiy = el enviado, ta es partícula de acusativo) (2).

El examen que acabamos de hacer de los carines del Perú, comprueba plenamente nuestras aserciones sobre el origen $y$ evolución de esta clase de construcciones. En efecto, vemos que originadas del deseo de impedir un mal, cubriendo, sin duda, su fuente, evolucionando, se transforman en lugar de descanso o en la residencia de un espíritu poderoso, que se trata de conciliar, estableciendo entre él y el caminante, una relación o parentesco, al entregarle éste una parte de sí mismo, tal como la saliva, o las pestañas $y$ cejas.

Mas el primitivo móvil, permanece claramente visible, en muchos hechos (3), tales co-

(1) Holguín, Vocabulario de la lengua general del Perú, llamada quichua o del Inca. En los Reyes, MDCXIII, pg. 22.

Tschudi (J. J. von), Die Keshua Sprache, Worterbuch, Wien, 1853, pg. 47.

Middendorf, Worterbuch des Runa Simi oder der Keshua Sprache. Leipzig, 1890, pgs. 49 y 52.

12) Holguín, Gramática y arte nueva de la lengua general de todo el Perú, llamada lengua Quichua, Lima, 1607. fol. 2. En jibaro apachita, quiere decir, padrecito.

(3) Que los antiguos Peruanos opinaban, que en las cumbres y pasos de la cordillera, existian espíritus malignos, lo 
mo el temor de desencadenar tempestades, creyendo que, sin depositar una piedra en el carín, no es posible transitar por tal o cual desfiladero, y en muchos más, como lo habrá advertido el lector.

Largo ha sido el espacio que, al examen de los apachitas hemos dedicado; detención, que era indispensable, para esclarecer materia tan intrincada y fenómeno que ha ocupado tanto a los que acerca del antiguo Perú han escrito. Mas no creemos que haya sido inútil nuestro trabajo, pues nos parece que hemos logrado determinar el fundamento y evolución del rito de arrojar piedras a otros objetos, igualmente vulgares $\theta$ insignificantes, en lugares determinados, demostrándose una vez más, la utilidad del método comparativo, con el que nos proponemos analizar, las creencias de los súbditos de los Incas.

Antes de terminar este capítulo, es preciso que señalemos otra costumbre, observada

sabemos con seguridad, ya que nos consta que creían que en estos lugares se encontraban los Quintas, o almas de los muertos en las guerras; $y$, para defenderse de sus ataques, imploraban a los hircas y ponían una soguilla de hicho, torcida con la mano izquierda. Véase Avendaño, Sermones en Quichua y Castellano, Vol. I, fol. 56, Lima, 1649. 
en el Perú por los caminantes, la que, los po$\cos$ autores que la recuerdan, han descrito siempre, juntamente con las apachitas.

Las tocances (tokay = escupir, tokanca = él escupirá), eran pedrones situados al fin de las subidas $y$ en los que escupían los viajeros, para no tener sed $y$ adquirir nuevo vigor (1). Muy grato nos sería estudiar prolijamente, este hecho, analizando aquellos que se le asemejan, observados en otros países; pero esto demandaría más espacio del que conviene con-

(1) Quando suben algunas cuestas o cerros, o se cansan en el camino llegando a alguna piedra grande que tienen ya señalada para este efecto escupir sobre ella (y llaman a la piedra y a la ceremonia Tocanca). Arriaga, Extirpación de la Idolatría, Lima, 1621, pg. 37.

Las piedras que vuestros viejos llaman Ttoccanca, no son Dios. Los hechizeros dizen, que quando los Indios van caminando en llegando a la cumbre del cerro donde ai rna placetilla, y en medio de ella está vna piedra parada, y que alli auian de escupir los Indios, y otrecer la saliua a aquella Huaca, para que no se les seque la boca a los caminantes, ni les falte el agua. Este hijos, es vn grande error. Dime, esta piedra tiene virtud para humedezer la boca? Si es assi. Dime el medicamento tiene rirtud para curar estando apartado del enfermo? No por cierto. Dime quando tu tienes hinchada una pierna, no pones el medicamento encima de la hinchazon? Si el medicamento estuuiera lexos, sanaras tu? No. Luego si esta piedra grande no te la pones dentro de la boca no te quitará la sed? No echas de ver que lo que dizen los viejos, es inuencion del Demonio; para que adores a essa piedra, y le ofrezcas tu saliua. 
sagrar a rito, que ocupa lugar tan secundario en la religión peruana $y$ que ha sido, satisfactoriamente explicado por Hartland, quien, despnés de estudiar detenidamente, las usanzas, relacionadas con la saliva, opina, de acuerdo con Oombie, que están basadas en la crencia de que la saliva contiene parte de la vida del que la emite, y que escupir en una persona es trasmitirle algo de su elemento vital, ya que al dar la saliva, le da una parte de sí mismo, entregándole una como garantía (1). Lo cual aplicado al caso presente, equivale a decir que, creyendo congratularse con el genio del lugar, para que no les aflija con sed y cansancio, escupen en la piedra en que reside, para formar, entre él y el caminante, confraternidad y parentesco.

(1) Hartland, The legend of Perseus, Vol. II, pgs. 258 a 260 , Londres. 


\section{CAPITULO I V}

\section{MONTES ADORADOS}

Taine, perspicaz filósofo $\mathrm{y}$ erudito historiador, aplicando a la crítica del arte $\mathrm{y}$ a la historia en general, teorías ya conocidas antes de él, pero que, entre sus manos de exquisito artista $y$ de inflexible lógico, convirtióse en un todo armónico $\mathrm{y}$ seductor, ha dicho que los hechos humanos, son el producto de tres elementos: el medio, la raza y la época (1). Esta feliz doctrina, demasiado exclnsiva y estricta, cuando se la aplica a los actos de una personalidad aislada, ya que, en tal caso, sería error prescindir del elemento indiridual, es luminosa y veraz, cuando con la debida discreción y prudencia, se la emplea en la investigación de grupos de hechos, suficiente-

1) Taine, Histoire de la Literature anglaisse Introduction, Vol. I.

Originer de la France contemporaine. Introduction.

Histoire de l'art. 
mente, numerosos, para que, oponiéndose y contrapesándose, desaparezcan los elementos personales y sólo aparezcan los que son generales $\mathrm{y}$ propios de la colectividad, o de aquellas actividades, que son el producto de todo un pueblo. Así teniéndola en cuenta, al examinar los cultos de los antiguos Peruanos, comprenderemos muy bien la enorme influencia que en ellos han ejercido el ambiente y configuración física del país, en que se desarrollaron.

Ya que se trata de fenómenos religiosos primitivos, que, tanto por pertenecer más al reino de lo emotivo que al de lo inteligente, y cuanto por su carácter, francamente colectivo y popular, escapan casi por completo del imperio del individuo $y$ del libre arbitrio, siendo su elaboración y evolución, obra de la masa, cuyos actos tampoco tienen de libres $\mathbf{y}$ de conscientes.

De los tres elementos que, según el crítico francés, determinan la orientación de las obras del hombre, ni la raza, ni la época han podido ejercer en la religión peruana tanto inflajo como el ambiente; puesto que trata de un pneblo, que ha vivido, durante muchos siglos, en an mismo país, en el mismo: lugar, 
en el cual ha erolucionado la raza, así podemos estar seguros, que las características do ésta son, en gran parte, producto de las condiciones del medio.

En cuanto a la épcé, osia cis, el momento de evolución en que so k. llir el pueblo, es evidente que el csick le civilización, en el cual so evcontrabau lrs anfiguos peruanos, no podía ser mis propicio, para que el ambiente $y$ condiciones físicas de la vida, ejercieran profando inHojo on la religiosidad peruana.

Payne, en su erudita Historia del Nuero Mundo (1), ha demostrado cuán sirandemento han influído en la formación do los mitos, creencias y supersticionos de los pueblos americanos, sus necesidades alimenticias y los medios de que ban dispuesto para satisfacer!as. Mas no sólo por esto canal, hase dejado sení: la infuencia del ambiente, sino gue también en laz concepciones del hombre primiliro, han influído el paisaje y el clima. Viviendo al pie de les Andes, en sus repliernes, en sus cumbres, en los inlinitos valles, que la grian cordillera oculta en su seno, el indígena de

(1) Payne, History of the New World, Called Aner'in, Oxtom, 1sis.?.

Religión de! Imresio de los Incas

20 
la Sierra del Perú, no podía menos de ser montañés, en su religión, como en su carácter.

Las montañas rodeaban su cuna, tras ellas, nacía y se ocultaba el sol, en sus grandes cumbres se formaban las tempestades $y$ de ellas salían las nubes, preñadas de rayos; en fin, entre los flancos de la montaña estaban los manantiales, orígenes de los ríos, cuyas aguas serríanles para el riego fecundador de la madre tierra, de cuyos productos virían.

Las altas cimas, ocultas, muy a menudo, por espesas nubes, perdíanse en el cielo, estableciendo contacto inmediato entre la tierra y el mundo superior. Las grandes montañas terminaban en inaccesibles picos o cubríanse de niere, sobre la cual brillaba, en no pocas ocasiones, el viro fulgor de las llamas volcánicas, del fuego inconsumible, del fuego que no han encendido los hombres.

En el voluble cielo del trópico, tan pronto encapotado y gris, como transparente y azul, las nubes, al pasar por junto a las escarpadas rocas, que, en muchos lugares, coronan la gran cordillera, toman formas fantásticas $\mathbf{y}$ grandiosas, que juntamente con la austeridad majestnosa del paisaje, excitan en el viajero, que, junto a ellas pasa, un místico senti- 
miento de terror y admiración por la nataraleza, cuyo poder le sorprende $\mathrm{y}$ aplasta. ¿Qué cosa más natural que, en la mentalidad del primitiro, del ineducado, este sentimiento místico, se cenvierta en adoración?

$Y$ si el culto de las montañas es explicable, isorprenderános el de los rolcanes?

Imposible nos parece, que una raza animista, deje de prestar reneración $\bar{g}$ culto a manifestaciones tan extraordinarias $\mathrm{y}$ sublimes de la naturaleza.

Quien haja risto, de cerca, alguna de aquellas grandes moles andinas, sobre las que flota, a menudo, un inmenso penacho de humo negro, iluminado de noche por numerosas centellas; aquellos flancos abruptos, destrozados por los repentinos deshielos, que han puesto a la rista las entrañas del monte, desnudo de toda regetación, con frescas huellas de formidables incendios, $\mathrm{y}$ haya escuchado el ronco fragor de truenos subterráneos, y visto estremecerse la montaña, comprenderá muy bien el respeto y reneración de que los volcanes han sido objeto, aún sin tomar en cuenta el terror (fuente fecunda de culto) que debían inspirar, por las desgracias y destrozos, que en cada erupción producían. 
Así, la antigiiedad clásica, adornó con bellos mitos el cráter del Etna, en donde arrojaba rasos preciosos, incienso y otros dones a los diozes del lugar, para tenerlos gratos (1).

In Dongs-Erok, o montaña de humo, hay una carerna, on donde, según dicen los Masai, viven gentes de su nación, ya que, desde la abertura del antro, aseguran que se oyen las roces de las gentes $y$ el mugir do los ganados. A esta cueva van las mujeres a orar y ofrecen mantequilla y miel a sus moradores, esperando que, por la noche, saldrán a comer los dones allí depositados; mas las estériles no hacen estos sacrificios, pues saben que no serán aceptados (2).

Al Nordeste de Naifacha, so eleva Bonyo Buru, monte de 2.800 metros de altura, en cuya cúspide hay solfataras, que arrojan gases encendidos, a intervalos regulares y cortos.

Thomson ascendió a esto rolcán, acompañado de un influyente Masai, el cual le hizo tomar puñados de hierba, quo todos los via-

(1) Frazer, Pausanias, Tol. III, pg. 389, London, 1898.

Id., The Golden Bough. A Study of Magic and Religion, London, 1914, Tol. V, pg. 222.

Smith, Dictionary of Grec and Roman Geographie, London, 1856.

(2) Hollis, The Masai, Oxford, 1905, pg. 280. 
jeros arrojaron en una de las solfitaras, para propiciar a los espíritus de la tierra.

A alguna distancia, encontraron una roca, de la cual salían rapores calientes, que, con la humedad $\mathrm{y}$ calor, descomponían la piedra en una especie de barro colorado, con el cual se untaban los Masai, como con una medicina muy eficaz (1).

En el camino, que conduce al rolcán Sineroe, uno de los volcanes más elerados de Jara y en un lugar cercano al cono, desde donde se le ve muy clara $y$ distintamente, has dos ídolos, que los naturales adoran, ofreciéndoles comida, para obtener el faror del dios del monte (2).

El rolcán Bromo es adorado, principalmente, durante la fiesta annal, que celebran en su honor los Javaneses de la recindad, que, si bien de religión brahamánica, no son tan apegados a sus ritos, como los de la Indiá.

En el mar de arena, que rodea al cráter, hay, desde el día anterior a la fiesta, gran animación 5 rense muchos grupos de gentes, éstos rezando, aquéllos comiendo, ótros divirtiéndose. 341 y 342.

(1) Thomson, Through Masai land, London, 1885, pgs.

(2) Stigand (J.A.), The Tolcano of Smeroe Java. The Geographical Journal, Fol. XXVIII, pg. 621, London, 1906. 
Machos comerciantes de amuletos, especialmente de piedras, encontradas el año anterior en el volcán y cuyo poder es infalible contra toda enfermedad, establecen improvisados almacenes, colocando talismanes sobre un tapiz.

En el arenal, se serguen multitud de tiendas y ante la principal, se sitúa el Jefe de los sacerdotes, $\mathrm{y}$ a poca distancia de él, disponen doce esteras, ocupadas por sacerdotes jóvenes, que venden a los derotos incienso $\mathrm{y}$ mirra. En ángulo recto, con la línea formada por estas esteras, hay otras doce, en las cuales están otros renerables sacerdotes, de mayor edad, cada uno de los cuales tiene a su lado un sirriente, que, con grandes abanicos, les tapa el sol. Delante de cada uno de estos sacerdotes, hay un pebetero encendido.

Al rededor de estos oficiantes, hay multitud de gente, que espera su turno, para hacerles bendecir las cosas que llevan, para sacrificarlas al volcán, las cuales son cocos, mangos $\mathrm{y}$ otras frutas; legumbres, pollos, pastas, seda, monedas de oro, plata $\mathrm{y}$ cobre.

La bendición consiste en unas cuantas preces, tras las cuales el sacerdote echa un poco de agua sobre el objeto, recitando luego en coro, todos sus compañeros, cierta oración. 
Cuando han permanecido en este lugar el tiempo necesario, a una señal del sacerdote más anciano, que es esperada con ansia y después de rogar al monte que continúe mostrándose favorable, toda la muchedumbre principia a correr desaforadamente hacia la cima, pues tiene por agüero de felicidad, llegar primero al borde del cráter. Los sacerdotes ancianos se detienen aquí $\mathrm{y}$ allá, para hacer oración $\mathrm{y}$ tomar aliento.

Los peregrinos entregan sus ofrendas a los sacerdotes, quienes las bendicen nuevamente $I$ las deruelren a sus dneños, para que las arrojen por las abruptas paredes del cráter, por las cuales se ren descender también algunas aves riras.

$\mathrm{Al}$ volver a sus casas, los concurrentes celebran varios juegos por el camino (1).

La opinión es de que los espíritus de los muertos, durante el año, permanecen en el mar de arena, hasta ser armitidos en el cráter, mediante los sacrificios ofrecidos en la fiesta anua. Se cuenta que, en tiempos antiguos, un jefe sacrificó un hijo suyo al monte (2).

(1) Barrington d'Almeida (W'), Life in Java, London, 1864, Vol. I, pgs. 166 a 174.

(2) Frazer, The Golden Bough, Vol. V, pg. 218, London, 1914. 


\section{Religión del IMPERIO De laos Ixdas}

En la pequeña isla de Ternate, hay un volcán, formado por tres conos superpuestos, cuyas erupciones son frecuentes y mus destructoras. Según los Galalareses de Halmahera, el Sultán de lit isla, exigía de ellos varias víctimas humanas, para arrojarlas en el cráter del rolcán, para tenerlo grato y proteger sus dominios, de los destrozos consiguientes a una recrudecencia de actiridad rolcánica (1).

En Siam, isla de las Indias Orientales, perteneciente al Archipiélago Sangí, un niño, robado en una isla recina, era inmolado, anualmente, al volcán, para que so esturiese tranquilo. Con el andar de los tiempos, el niño fue sustituído por un mañeco (2).

En el cráter del rolcán Kiraranca de Hawai, habitan los dioses Pelé y Nahraarii y otros espíritus, que, cuando están irritados, arrojan nubes de humo, hacen llorer piedras 5 ceniza, enruelven la tierra en obscuridad, o causan insólitos aguaceros. Oféndeles el que los hombres se apoderen de los ohelos o fresas sagradas, que crecen en el cono, o que echan piedras o tierra en su morada (3).

(1) Frazer, Op. cit., pg. 216.

(2) Frazer, Op. cit., Tol. IV, pg. 218.

(3) Ellis, Polynesians researches, Tol. IT, pg. 207, London, S D. 
Los aborígenes sólo comen los ohelos, después de ofrendar algnnos al rolcán, lo que hacen arrojándolos en el cráter, hacia la fumarola principal (1).

Es tradición, que los espíritus del monte vinieron a Hawai de otras islas, en tiempos mitológicos, cuyos nombres son: Kamoho-á-rï (el Rey rapor), Tapoha-i-tahiora (la explosión en el lugar de vida), Te-ua-to-po (la lluria de la noche), Te-o-ahi-tama-tama (el muchacho de guerra con flechas de fuego) I Tane-hetiri (el hermano del rayo), hermanos de las diosas Pelé, que era superior a todos, $\Sigma$ de Makorawawahi waa (la terrible destructora de canoas), Hiatawawahi-lani (la que tiene las nubes en el cielo), Hiatataarare - mata (la que tiene la nube $y$ cuyos ojos muérense prestos $y$ miran por sobre los hombros), Hiata-hoy-tepori a Pelé (la que tiene la nube $\mathrm{g}$ besa el regazo de Pelé), Hiata-tabu-enaena (la mon. taña en ascuas, que leranta nubes), Hiata tareïa (el masetero adornado con guirnaldas) I Hiata-opio (la joren tenedora de nubes).

Todas estas hermanas, vivían en el rolcán, donde residían también, a menudo, los raro-

(1) Ellis, Op. cit., Vol. IV, pg. 234-236. 
nes, si bien éstos tienen otras moradas en la isla, las cuales se hallan, sobre todo, en las cumbres nevadas.

Estas deidades acostumbraban comunicar sus cambios de dirección, por medio de temblores o de erupciones del monte en que se establecían, lo que también hacían, cuando no les pagaban los debidos sacrificios, que consistían en pescado y otras comidas (1).

Pelé tenía sus sacerdotes, a los cuales inspiraba, tomando cuerpo en ellos. Estos eran, ordinariamente, mujeres; úna, a quien conoció Ellis, afirmaba que ella era la misma diosa, inmortal como ella y que vivía en medio del brillante fuego del rolcán, en compañía de los espíritas de aquellos, cuyos huesos habían sido echados al cráter (2).

En las vecindades del monte Kirauca, había un templo, dedicado a la diosa, con varias rudas estatuas de piedra, cubiertas con telas blancas y amarillas, junto a las cuales veíanse flores, pedazos de cañas de azúcar y otras cosas semejantes, depositadas por los viajeros, que siempre, al pasar por este sitio, ofrecían algún sacrificio.

(1) Ellis, Op. cit., Vol. IV, pgs. 448 a 451.

.2) Ellis, Op. cit., Vol. IV, pgs. $310-312$. 
Anualmente, los moradores de Hamahua, celebraban en este templo, una fiesta en honor de Pelé, para propiciarla y librar al país de los estragos de una erupción. A dicha fiesta concurrían todos los ministros de su culto y en ella se sacrificaba gran cantidad de perros y frutas.

Era muy usado, por los que por el borde del cráter transitaban, el arrojar en él un me. chón de pelo (1).

El volcán Tongariro era objeto de culto para los moradores de la isla sententrional de Nueva Zelandia (2).

Los Koniagas creen que el humo que sale de los volcanes, es el de las cocinas de los dioses o de sus baños de vapor. Esta misma idea se encuentra mucho más al Sur. Así, en California, los recinos del monte Thasta, dicen, que un gran espíritu agujereó el monte, construyéndose, de este modo, su wigwan (3), siendo el humo que sale del cráter el del hogar del genio (4).

\footnotetext{
(1) Ellis, Op. cit., Vol. IV, pg. 350.

(2) Lublock, The Primitive civilitation, pgs. 300 a 316.

(3) Dorman, Primitive supertitions, Philadelphia, 1881, pg. 302.

(4) Id. Id., Loco cit.
} 
Según la creencia popular, los montes de Unimak y de Unalaska, allá, en tiempos remotos, se movieron guerra, deseosos de dominar los únos a los ótros, para lo cual luchaban, arrojándose piedras inflamadas. Los pequeños volcanes no pudieron soportar el bombardeo, quo les infligían los mayores, de modo que estallaron en pedazos, quedando solos en la lid, el Macuchen en Unalaska y el Retchesnoi en Unimak. El fragor de la lucha fué tal y tál la cantidad de piedras y ceniza que se arrojaron los dos adversarios, que todo sér viviente pereció. Cuando el Retchesnoi comprendió que sus esfuerzos eran vanos, prefiriendo la muerte a la derrota, hinchóse hasta extinguirse. Su rencedor, satisfecho del triunfo, dnerme tranquilo y sólo humea de tiempo en tiempo (1).

El monte Hood, volcán apagado del Oregón, está, según reza la leyenda, habitado por hombres ciegos (2)

En Méjico, en donde el culto de los montes ocupaba tan prominente lugar (como más adelante veremos), los volcanes no podían menos de ser reverenciados, como las montañas más

(1) Reclus, Les Primitives, París, 1903, pg. 59.

(2) Dorman, Loco cit. 
excelentes y poderosas, pero su culto so confundía con el de las demás grandes moles de la cordillera, por lo cual, aquí no describiremos los ritos con que se lo celebraba.

Entre los volcanes del país de Anahuac, el más notable es, quizás, el Popocatepelt, nombre que en azteca, significa monte que humea (popoca = que humea, tepelt = monte). Era reverenciado como el cerro más principal, especialmente, por los que virían cerca. Hacíanle continuos sacrificios y honrábanle de un modo especial, cuando celebraban la fiesta de los montes.

Atribuíanle el origen de ciertas enfermedades, $\mathbf{y} \operatorname{los} q u e$ de ellas sufrían, hacían fiestas y sacrificios en su honor, rindiendo culto a las imágenes que lo representaban, si bien esto no era exclusiro de este monte, sino común a todos los demás (1).

Los antiguos Mejicanos decían que el nevado de Iztaecihualt era la mujer de Popoca-

(1) Sagahum, Historia de las cosas de Nueva España, México, 1829, Vol. I, pg. 3t.

Durán, (Fray Diego), Historia de las Indias de Nuera España e islas de Tierra Firme, Néxico, 1880, Tol. II, pgs. 202 a 207.

Robelo, Diccionario de mitologia, nahua. Anales del Museo Nacional de México, Segunda serie, Vol. V, pg. 37, México, 1908. 
tepelt y como a tál la adoraban en los varios templos que tenía, sobre todo, en una cueva situada en la misma montaña. En el templo major de Méjico, había una imagen de esta diosa, en forma de palo, vestida de azul, cubierta la cabeza con una tiara de papel blanco, en cuya parte posterior había una medalla de plata, de la cual salían plumas blancas y negras, caíanle por la espalda varias tiras de papel, pintadas de negro. Estaba en una pieza especial y servíanla, día $y$ noche, las dignidades del templo. Su fiesta se hacía en el mes de Tepeilhuit, sacrificándole una esclava vestida de verde, con una tiara blanca, para significar que la montaña, cubierta de bosque, estaba coronada por nieres eternas.

En el propio monte eran inmolados, an ualmente, cuatro niños pequeños, dos varones $y$ dos hembras, al mismo tiempo que le ofrecían cosas mnjeriles. Estos sacrificios duraban dos días $y$ eran acompañados de grandes plegarias $y \operatorname{ayunos}(1)$.

(1) Durán (Fray Diego, Historia de las Indias de Nueva España e islas de Tierra Firme, Vol. Il, pgs. 199 a 202, México, 1880 .

Robelo, Diccionario de mitologia nahua. Anales del Museo Nacional de México, Segunda Epoca, Tol. IV, pg. 92, México, 1907. 
Después de Popocatepelt, quizás no hay otro volcán más conocido en Méjico, que el pico de Orizaba o Poyauhtecal, uno de los montes más venerados por los aborígenes del país y al cual atribuían aquellas enfermedades, que creían que eran causadas por el frío, y, por esto, los que tales males sufrían, hacían su imagen y le ofrecían sacrificios (1).

Los Quichés hacían una fiesta annal al volcán de Quezaltenango (2).

El Curaca Chorotega, Senderi, contó, al cronista Gonzalo Fernández de Oviedo y Valdez, que él y otros Caciques habían bajado al cráter del volcán Masaya, a verse con una vieja muy arrugada, con pechos que le llegaban al omblign, de escaso e hirsuto pelo, de dientes largos, agudos y negros, para consultarle si harían guerra, si había de llover y si la cosecha sería buena, ya que a esta vieja atribuían estos indios, los terremotos y temporales y "porque pensaban que todo su bien o su mal procedía della.»

(1) Sagahún. Historia de las cosas de Nueva España, México, 1829, Vol. I, pg. 36.

Robelo, Diccionario de mitología nahua. Anales del Museo Nacional de México, Segunda Epoca. Vol V, pg. 37, México, 1908.

(2) Dorman, Primitive superstitions, Philadelphia, 1881, pg. 309 . 
Un día o dos antes de penetrar en el cráter, arrojaban allí, en sacrificio a la vieja, «un hombre e o dos o mas e algunas mujeres e muchachos e muchachas.»

« A par de la boca desta sima do Masaja estaba un gran montón de ollas e platos e escudillas e cantaros quebrados e otras vasijas, e algunos sanos $\theta$ de muy buen ridriado o loça de la tierra, que solian llevar los indios cuando alli yban llenos de manjares e diversos potajes e los dexaban alli diciendo que eran para que la rieja comiese.» (1).

Los aborígenes de Chilo, que vivían cerca de volcanes, les honraban con sacrificios (2).

De los numerosos rolcanes actiros que hay en el país que denominaron los Incas, la mayor parte de ellos se encuentra, desgraciadamente para el estudio que nos ocupa, en las extremidades setentrional y meridional del vasto Imperio, regiones que, en los tiempos prehispánicos, nos son mucho menos bien conocidas que el centro de Tihuantinsuyo, siendo muy escasas las noticias que tenemos acerca de las supersticiones de los indios que en ellas moraban.

(1) Oviedo y Valdez, Historia General y Natural de las Indias, Vol. IV, Madrid, 1855, pg. 75.

(2) Dorman, Op. cit., lig. 308. 
Hay bien fundadas razones para creer que el Ootopaxi era adorado por los indios de Mulaló (1).

Oonsta que los aborígenes de Patate y los demás pueblos circunvecinos, rendían culto al Tungurahua (2), al cual los Purubaes de San Andrés de Janjí, tenían por mujer del Ohimborazo, asegurando que, a pesar de sus inmensas moles, se visitaban y comunicaban (3).

Notable semejanza con la leyenda, que, poco há transcribimos, relativa a los montes de Unalaska, tiene la que los Yauyos contaban acerca de Pariacaca o Iaro, cordillera de nieve y monte, el más alto de esta parte de los Andes, de forma cónica y junto al cual había otro cerro más pequeño, acerca del que narraban muchas historias, entre ótras, que, antes de ser montaña, había sido hombre (4).

(1) González Suárez, Atlas Arqueológico.-Id. Prehistoria.

(2) González Sućrez, Op. cit.

(3) Paz Maldonado, (Fray Jhoan), Relación del pueblo Sant Andrés de Xunxi para el muy ilustre sefror Licenciado Francisco de Aucibay del Consejo de su Majestad etc. etc. Relaciones Geográficas de Indias, publicalas el Ministerio de Fomento, Perú (editado por Marco Jiménez de la Espada), Vol. III, pg. 152, Madrid, 1897.

(4) Avila, Relación de la Idolatría de los Indios de este Arçobispado de los Reyes que sea descubierto y diversidad do Idolos que adoran, Apéndice. Religion del Imperio do los Incas 
De los mitos de Pariacaca, hay dos relaciones minuciosas, que analizaremos en su lagar, a más de publicarlas en los apéndices de de esta obra; la de Arila, "Relación de los falsus dioses idolatrías y supersticiones de Huarochirín y la Quechua, de autor desconocido, que principió a compendiar y traducir Avila, en el tratado citado.

Decían que, en tiempos remotos, gentes del valle del Rímac, penetraron, por la fuerza, en Yanyos y poblaron un asiento, que, sin duda, en memoria de sus fundadores, llamóse Lima; llevaron consigo estos invasores un ídolo, llamado Guallallo, al cual sacrificaban, en determinadas épocas del año, niños y mujeres, hasta que un día se les apareció $\mathbf{P a -}$ riacaca en el lugar, en donde está abora el pico de este nombre, y les exhortó a abandonar el culto de dios tan poco humanitario y a adoptar el suyo, ya que sólo exigía que le inmolasen animales, a lo cual objetaron que, si tál hiciesen, Guallallo se rengaría matando a todos; respondióles Pariacaca, ofreciendo que él los defendería y echaría del lugar a su rival.

La lucha entre los dos dioses, que no eran ótros sino dos volcanes, duró tres días y 
tres noches, saliendo victorioso Pariacaca, pues arrojó tal cantidad de agua y granizo sobre Guallallo, que éste huyó a la Provincia de Jauja, formándose en el lugar, en que primitivamente se encontraba, un lago. Por esto los Yanyos veneran a Pariacaca y le ofrecen sacrificios, subiendo, para este efecto, a lo más alto de la montaña (1).

(1) Cuentan estos indios desta provincia una fabula donosa que ellos tienen por muy verdadera, y dicen que los Yungas, sus vecinos del valle de Lima, entraron por esta provincia, haciendo guerra $y$ poblaron un pueblo que hoy se llama Lima ... y que en el lago que está al pie desta alta cierra de nieve de Pariacaca, tenian un idolo que llamaban Guallallo al cual sacrificaban algunos tiempos del año niños y mugeres; y les aparecio donde esta este alto pico de nieve, un idolo que se llamaba Pariacaca y les dijo a los indios que hacian este sacrificio a idolo Guallalló, que ellos adoraban: "No hagais eso de sacrificar vuestros bijos y mugeres, sacrificame a mi, que no quiero sangre humana, sino que me sacrifiqueis sangre de ovejas de la tierra, quellos llaman llamas, y corderos, que con esto me contentare." I que ellos le habian respondido Matarnos ha a todos si tal hacemos el Guallallon y que el Pariacaca habia replicado. "Io peleare con el $\mathrm{y}$ lo echare de aqui.» $\mathrm{Y}$ asi tres dias con sus noches peleo el $\mathrm{Pa}$ riacaca con el Guallallo y lo vencio echándolo a los Andes, que son unas montañas de la provincia de Xauxa, haciendose el Pariacaca la cierra $y$ alto pico de nieve que hoy es y el Guallallo otra cierra de fuego. I asi pelearou; y el Pariacaca echaba tanta agua $\exists$ granizo, que no lo pudo sufrir el Guallallo $\mathrm{y}$ asi lo vencio $\mathrm{y}$ hecho donde dicho es, $\mathrm{y}$ de la mucha agua que le echo encima, que quedo aquel lago que hoy es, que llaman de Pariacaca.... I lo tienen hoy creido los indios 


\section{RELigión Del IMPERIO DE LOS INCAS}

La gran antiguiedad de este culto, está atestiguado por el nombre de la montaña, pues circunstancia muy de tenerse en cuenta, no pertenece a la lengua quichua, sino a la aymara, en la cual significa, piedra caliente que abrasa (pari=caliente, que abrasa; caca=piedra (1).

Era Pariacaca deidad famosa, de las más notables de Huarochirí $\boldsymbol{y}$ ocupaba lugar preeminente en las fábulas cosmogónicas de aquellos indígenas, como se rerá más adelante (2).

Rendíanle culto cada luna, ofreciéndole sacrificios, para los cuales tenían, en 1582, los Caciques de Anan Tauyo, cuatrocientas llamas y catorce rasos de plata (3).

y suben a lo mas alto de dicho cerro de nieve a ofrecer sus sacrificios al Pariacaca y por otro nombre Yaro, que asi dicen quedó hecho ciera de nieve después de la dicha batalla. Dávila y Briceño Corregidor de Guarocheri, Descripción y relación de la provincia de los Yauyos toda Anuan Yauyos y Lorin Yauyos. Relaciones Geográficas de Indias. Publícalas el Ministerio de Fomento, Perú, (editor Jiménez de la Espada,) Tol. I, pgs. 71 y 72 , Madrid, 1881.

(1) Bertonio, Vocabulario de la lengua Aymara, Edición de Platzman, Parte 2, Leipzig, 1879.

(2) Avila, Relación de la Idolatría de los Indios de este Arzobispado de los Reyes etc. Apéndice

Id. Id., Tratado de los Evangelios, folio 27, verso de los sin numerar, Lima, 1616.

(3) Este dicho cerro de Pariacaca ques (sic) el mas alto desta cordillera, $y$ por ser tan famoso de alto tomo nombro 
Los del ayllo, llamado Yampilla, reuníanse, a este efecto, en un prado distante, poco más o menos, una legua de Huarochirí, en donde todos juntos adoraban a Pariacaca, a Chupinamocc y demás Huacas; en dicho lugar había un sumidero, ingeniosamente arreglado, con mucho disimulo, por donde echaban la sangre de los animales inmolados, así como la chicha y otras cosas que ofrecían a sus dioses (1).

Si Pariacaca era adorado continuamente y, de un modo especial cada luna, su gran fiesta sólo se verificaba cada cinco años, con-

mucha parte de esta dicha cerrania y cordillera que corre por este dicho reino a lo largo, de Pariaca que este (sic) cerro alto dicho llaman tambien Iaro, porque fue adoratorio famoso donde hacian los indios sus sacrificios $\mathrm{y}$ adoratorios $\mathrm{y}$ aun hoy dia no estan libres dello porque habra cuatro años poco mas que yo, el dicho corregidor, castigué algunos caciques, siendo corregidor de la parte superior desta provincia que llaman Anan Yauyos y les quite cuatrocientas cabezas de ganado desta tierra cun catorce vasos de plata que hacian sus sacrificios cada luna. Dávila y Briceño (Corregidor de Guarocheri, Descripcion y Relacion de la provincia de Yauyos toda Anan Yanyos y Lorin Yauyos. - Relaciones geográficas de Indias. Publicalas el Ministerio de fomento, Perú (editor M. Jiménez de la Espada), Vol. I, pg. 71, Madrid, 1881.

1) Carta del Padre Fab ín de Ayala, al Arzobispo de Lima, desde Santiago de Anchocaya, el 12 de Abril de 1611, Apéndice. 
curriendo a ella toda la provincia; dicha fiesta duraba cinco días (1).

No sólo aquellos montes que, con sus formidables manifestaciones ígneas, con los destrozos y ruinas que acumulaban, cuando, saliendo de traicionero letargo, daban nuevas señales de actividad, imponían telror y respeto a los que virían en sus faldas, fueron adorados por los Peruanos que, si prontos a ofrecer sacrificios $y$ a hacer cuanto les era posible, para conciliar aquellos poderes, cuya temible influencia experimentaban, rendían también ferviente culto a los espíritus benignos, de los cuales creían haber recibido algún favor, para agradecerles sus beneficios, dando así, muestras de gratitud y para que no cesasen de prodigarles sus dones, manifestándose, de este modo interesados.

De allí el que rindieran culto a muchos montes, especialmente a aquellos cuya cima co-

(1) En resolución me dixo (Dn. Cristobal Choqqueaccaca) que aunque siempre toda esta provincia, y otras comarcanas adoraban por su Dios principal a Pariacaca y Chaupinamoec su hermana. Pero que cada cinco años se hazia una fiesta mny celebrada a que concurría toda la comarca y duraba cinco días, Avila, tratado de los Evangelios, Lima, 1646 fol. 27, verso de los no numerados. 
ronaba nieve eterna (1), pues teníanles por causantes de los muchos ríos, que de ellos se originaban y que tan preciosos les eran para su sustento, ya que, pueblo agricultor, que vivía en un país árido y que mediante sus ingeniosos canales de regadío llevaba el agua desde las escarpadas faldas de la cordillera hasta sus huertos, sólo podía esperar que, fertilizada la tierra con la humedad, le rindiese los frutos indispensables para su manutención (2).

No tan solamente por el motivo enunciado, rindieron culto los súbditos de los Incas a las graudes moles de la cordillera, cuya adoración, en un principio, es probable que se inspirase en otros móviles distintos de los de la gratitud. Muchos negros africanos, si bien creen en la existencia de espíritus benignos, se cuidan poco

(1) (Adoraban) las Sierras nevados que llaman Razu o por sincope Razo o Ritti que todo quiere decir nieve, Arriaga, Extirpación de la Idolatría, pg. 11, Lima, 1621.

Quien adora la Sierra nevada .... tirándose las cejas?

Villagómez, Carta Pastoral de exhortación e instrucción contra las Idolatrias de lus ILdios del Arzubispado de Lima, fol. 61 a 63 , Lima 1649 .

(2) Otros (adoraban; a la cordillera grande de la sierra nevada, por su altura y arlmi able grandeza, y por los muchos rios que salen della para los ritgos.

Garcilazo de la Vega, Comentarios reales, Lisboa, 1609, folios 10 verso. 
de ellos, pues no los temen, mientras tratan de congratularse con los genios malignos, a quienes atribuyen toda adversidad (1). De igual manera proceden, muy amenudo, los primitivos, cuyos dioses son más temidos que amados.

Así, si las fuentes, que brotan en los picos de los Andes, inspiraron a los antiguos peruanos, gratitud para con los montes, más vivo debió ser el sentimiento de respeto $y$ temor que las grandes tempestades $y$ nublados, que en ellos se formaban, suscitaron en el corazón de aquellos rudos habitantes, que tantas reces experimentaron, a no dudarlo, el furor de los vendavales, los destrozos de las heladas y los estragos de diluviales aguaceros, tan frecuentes $y$ repentinos en los valles, situados al pie de las grandes cumbres andinas, sin que haya sido extraña al carácter sagrado de los montes, el rayo, cuyo eco repiten y multiplican los riscos de la cordillera.

Imposible es formar una lista completa de todos los nevados que han sido adorados en el Perú, y más aún el precisar el origen

(1) Verneau (R), Les Hindembourg en bois des Negres do Loango. L'Antrophologie, Vol. XXVII, pg. 111, Paris, 1916. 
de su culto y los poderes que se les atribuían. Pero no por eso será menos interesante el examinar los ejemplos, que, de este culto se encuentran en las relaciones de los primeros españoles, establecidos en el Perú. Así, sabemos que el Chimborazo, (Chimbo-razo= Nevado de Chimbo, por otro nombre Urco-raso $=$ Cerro de nieve) una de las más imponentes y hermosas cimas de los Andes, fue reverenciado por los Puruhaes, quienes, al pie de las nieves, tenían edificado un templo, en donde se juntaba toda la gente de la vecindad, para hacer sacrificios. (1)

Oreían que era varón y decían que de él habían nacido. Ofrecíanle muchachas vírgenes y principales; llamas, dejándolas en libertad en el páramo, a las que nadie osaba hacer daño, de temor de que el monte se irritase y les enviase heladas y granizo. Había muchas, cuando el Licenciado Ortegón, Oidor de Quito, visitó aquella Provincia 5 , para quitar a los indios estas supersticiones, mandólas matar, acaeciendo, poco después, gran-

(1) Nuestras excavaciones arqueológicas en Puruhá, han demostrado que el Chimborazo es volcán prehistórico. Sobre su culto, véase nuestro artículo: Folk-lore del Chimborazo, Revista de la Asociación Católica de la Juventud Ecuatoriana, tomo III, pg. 369 y sig., Quito 1919. 


\section{des heladas, confirmándose los indios en su creencia (1).}

En la Provincia de Rucanas y Soras, jurisdicción de la ciudad de Guamanga, hay otro monte nevado, que adoraron los indígenas en su gentilidad; dicho Caruarazo (Karu $=$ combustible, razo $=$ nerado, esto es, nevado combustible), designación muy propia para un volcán. Palomino propone otra etimología

(1) Es tierra templada (Sant. Andrés de Xunxi), está á el pie del volcán llamado Chimborazo, que quiere decir en su lengua del Inga "cerro nevado de Chimbo al cual tienen en gran venelacion, $y$ lo adoraban $y$ adoran, aunque no á lo descubierto, porque dicen nazcieron del. Sacrificaban en este cerro muchas doncellas vírgenes, hijas de Señores, y obejas de la tierra; $y$ otras echaban vivas; $y$ hoy día (1582) hay muchas al pie de la nieve, á las cuales no matan los indios ni llegan á ellas para hacelles mal, por decir que el dicho volcan les hechara heladas en sus sementeras y granizos y lo tienen por abuzion. Y viniendo á visitar esta tierra el ilustrísimo señor almirante y duque don Diego Ortegon, por quiteilles este abuso, mandando á muchos españoles fuesen a matar destas obejas y que fuesen muchos indios con ellos; y fueron harto contra su voluntad $y$ dijeron $y$ aun hicieron grandes llantos, diciendo que se les había de helar las cementeras, por matar las obejas ofrecidas al volcan suso dicho; y sabiendo esto el diclo señcr risitador, los enrió, y a la vuelta hallaron los maizes helados, por haber helado aquellos dias $y$ cunfimaronseles su abucion $y$ atribuyeronlo a que por haber ido los espanoles a matar las olejas, habia helado; y castigules el señor imirante. Y no osan comer esta carne destas ovejas, por estar ofrecidas aunques muy buena carne. 
para este nombre, cuyo significado, es según el, nevado amarillo (de Karbua=amarillo); color que don Marcos Jiménez de la Espada, dice provenir de los gases sulfurosos, condensados sobre la niere (1).

El Ooropuna $($ Koro $=$ pelado, puna $=$ páramo; esto es, páramo pelado), monte cubierto de eternas nieres, era una huaca muy célebre, ya que a ella iban en peregrinación los Incas (2).

En la provincia de Collaguas vivían dos tribus, los Collaguas y los Caranas, diferentes

Alrededor del (Chimborazo', al pie de la nieve, hay hoy dia algunos edificios caidos donde acudia toda la tierra alrededor a ofrecer, cada rez que se les antrjaba. Fray Juan de Paz Maldonado, Relación del pueblo de Sant Andres Xunxi para el muy Ilustre Señor Licenciado Francisco de Auncibay del Concejo de su Majestad y su Oydor en la Real Audiencia de Quito. Relaciones geográficas de Indias, publicalas el Ministerio de Fomento, Perú (editado por Jiménez de la Espada), Vol. III, pgs. 150 a 152, Madrid, 1897.

(1) $\mathrm{Y}$ lo que en jeneral adoraban es un cerro nerado que esta en lo alto de la sierra desta provincia, que se llama Caruaraso que quiere decir niere amarilla. Hernando Palomino, Descripción de la Tierra del repartimiento de Atunsora encomendado a Hernando Palomino, jurisdicción de la ciudad de Guamanga. Relaciones geográficas, Vol. I, pg. 172.

(2) Coropuna que es en la provincia de Condesuyo es un cerro muy grande cubierto de nieve y los Reyes del Parú risitaban este templo. Cieza, Segunda parte de la Crónica del Perú, pg. 111, Madrid, 1880. 
entre sí por su lenguaje, trajes y costumbres. Los primeros deformábanse el cráneo, mediante una presión circular, que impedía el desarrollo de los diámetros antero posterior y transversal, produciendo un excesivo desarrollo vertical, lo que hacían dizque para tener las cabezas semejantes al Collaguata (Kolla = la sierra alta, buata = amarra, lazo), nerado al cual adoraban, asegurando que de él había salido mucha gente, la cual bajó al valle, venció $y$ sujetó a sus antiguos moradores, fundando la Nación Collagua (1).

Los Caranas aplastábanse el cráneo desde niños, oprimiendo el frontal $y$ el occipital $y$ tenían por pacarina a la alta sierra, denominada Guallcahuallca (roz a mmara huallke=pre-

1) Se llaman collaguas....por antigualla; tienen para si por noticia que se dan heredada de padres a hijos, que proceden de una guaca o odoratorio antiguo questá en los términos de la provincia de Tellilli, comarcana desta, ques un cerro nevado a manera de volcán, señalado de los otros serros que por alli hay, el cual se llama Collaguata; dicen que por este cerro ó de dentro dél salio mucha gente y bajaron a esta provincia y valle della, que este rio en que estan poblados, e vencieron los que eran naturales e los echaron por fuerza e se quedaron ellos.... dicho volcáu llamado Collaguata que antiguamente suele (sic) ser adorado de ellos, como cosa que tenian por fee que procedian de aquella guaca o adoratorio. Joan de Ulloa Moyollón, Relación de la provincia de los Collaguas. Relaciones geográficas de Indias, Vol. I, pg. 40, Madrid, 1885. 
ñada, huallke o duplicación superlativa) y la adoraban (1).

No eran éstas las únicas cumbres, cubiertas de nieve eterna, a las que rendían culto los naturales de aquellas regiones. También tributaban honores divinos al Suquilpa (suki = descolorido, pálido; alpa $=$ tierra ; esto es, Suquil$\mathrm{pa}=$ tierra descolorida), Apoquico (apu $=\mathrm{el}$ señor; el padre; quicu =árbol del páramo, esto es: señor del quico) y Omascota (uma $=$ cabeza, jefe; koto $=$ montón de objetos menudos, esto es: montón jefe) (2).

Adorábanles de pie, con las manos juntas, haciendo, al mismo tiempo, cierto sonido

(1) Los de la provincia de Carana tienen por antigualla que vinieron al asiento donde agora esta el pueblo de Carana de un cerro questa enfrente del que se llama Gualcagualca nerado ... Dicen también que algunos hermanos e compañeros suyos fueron desde el dicho cerro Gualcagualca bacia la sierra e poblaron el pueblo de Cavana Colla. Llloa Mogollón, Relación de la provincia de los Collaguas. Relaciones geográficas. Yol. I, pg. 40, Madrid, 1885.

(2) Las adoraciones que tenian eran las guacas, que las principales que habia en esta prorincia, so llamaba Collaguata, Suquilpa, Apoquico, Omascota, Gualcagualca. Todos eran $y$ son cerros altos nerados, que por algún beneficio que les venia dellos, como es que la nieve que cae de algunos de ellos riegan algunas tierras o se funda algún rio. Clloa Mogollón, Relación de la provincia de Collaguas. Relaciones geográficas, Vol. I, pg. 44, Madrid 1885. 


\section{ReLigión DEL IMPERIO DE LOS INCAS}

\section{con los labios, como para besar: reverencia tributada a todos los demás dioses (1). \\ Sacrificábanles intestinos de llamas y otros animales $y$, por orden expresa del Inca, en ciertas ocasiones, inmlaban hombres, siendo más común les ofrendasen imágenes de oro y plata (2).}

(1) La costumbre era, adoración (sic) parados alargando juntas las manos con gran demostración de humildad.

Llloa Mogollón, Loco cit.

Acosta, Historia natural $y$ moral de las Indias, Sevilla, 1590 , pg. 312 .

(2). Sacrificaban, era (sic) intestinos de corderos, de animales $y$ de conejos, que se llaman en su lengua cubies; $y$ cuando el dicho inga quería hacer algún sacrificio famoso $\theta$ aplacar alguna guaca que decir estar airada .... enviaba a mandar que sacrificasen hombres a las tales huacas .... e sin su orden no podian sacrificar indios. Asimismo hacian bultos pequeños de oro e de plata e lus sacrificaban.

Llloa Mogollón, Loco cit.

Las antecedentes palabras de Ulloa Mogollón nos traen a la memoria que, segín iuformes reridicos, se encontró, hace años, en los picos del Rumiñahui (Nudo de Tiupullo), una figurita de oro, de aquel tipo incaico bien conocido, que representa nua mujer desmula, tal como se re en la L 153 de Paessler, Ancient Perurian Art. Era uno de aquellos bultos de que habla el Corregidor de los Collaguas. ¿Sacrificarianse aquellis imágenes en lugar de mujeres? Figurillas, confeccionadas de un modo semejante, hay, que representan un varón o una llama. (Jijón y Larrea, Un cementerio Incásico en Quito. Quito 1918. L. XL, fg. 2, pgs. 51-ó3) siendo las más frecuentes mujeres; quizás, porque casi todos los sacrificios humanos que se ofrecian en el Perú eran do mujeres J porque no ralía la prena de sustitutr una llama por una 
Según Cieza de León, el tercer oráculo de los Incas, era el templo de Vilcanota. Esta palabra es de origen aymara, lengua en que significa Casa de lo sugrado (hnilcana=de lo sagrado, (mana wakonda, lucaca) uta=casa). Difícil es saber si el templo dió nombre a la montaña, o si fué hecho para adorarla; mas no nos sorprendería que baya sido el propio cerro la mansión de la fuesza mágico-sagrada, y el santuario tan sólo un lugar destinado al culto de ella (1).

Los indios de La Paz tenían por huaca al Ilimani (2), cuga extra, rdinaria mole de eterna nieve, les parecía cosa dirina (3).

figura de metal precioso. El sustituír una victima humana por una imagen, es un procedimiento bien conocido (Frazer, The Golden Bough, Vol. IV, The Dying God, pgs. 214 a 220, London, 1914), del cual no faltarán ejemplares en este estudio.

La figurilla encontrada en el Rumiñahui, fué obsequiada a Pio X, habiéudola, previamente, colocado sobre un soporte de pésimo gusto.

(1) El tercer oráculo y guaca de los Incas, era el templo de Vilcanota. Cieza de León, Segunda parte de la Crónica del Perú, pg. 110, Madrid, 1880.

(2) Sobre el origen atacameno de este nombre, véase Uhle, Fundamentos étnicos de la región de Arica y Tacna - Boletín de la Sociedad Ecuatoriana de Estudios Históricos, Vul. II, pg. 20, Quito, 1919.

(3) Hay otra adoración que se llama Hillemana, que es una cierra alta cublerta de nieves, Cabeza de Vacia (Diego), 
No se limitaron los peruanos a adorar a aquellos montes, cuya cima permanecía siempre cubierta de hielo, sino que también rendían culto a muchas otras montañas, notables por su forma o tamaño, o a grandes rocas o piedras, llamándolas con nombres particulares y contando acerca de ellas variados mitos (1).

Los Guamachucos veneraban a dos altísimas sierras, dichas Xulcaguaec (sulká $=$ el mejor, el más joven; guaec=huaca (?), esto es: la mejor huaca) y Ianahuanca (yana $=$ compañero, sirriente; hnancu = gran piedra, esto es: el peñón sirriente), a las que acudían, cuando tenían guerra con sus recinos, para que les diesen fuerzas (2).

Descripción y relación de la ciudad de La Paz. Relaciones geográficas etc., Vol. II, pg. 71, Madrid, 1885.

(1) A Cerros altos y montes y algunas piedras muy grandes también adoran y mocha y les llaman con nombres particulares, $y$ tienen sobre ellos mil farulas de conversiones $y$ metamorfosis $y$ que fiueron antes hombres $y$ se convirtieron en aquellas piedras. Arriaga, Extirpacion de la Idolatria, pg. 11, Lima, 1621.

(2) Para cuando se alzaba alguna prorincia contra ellos tenian su idolo y guaca que se llamaba. Ianaguanca y con ella otra que se llamaba Xulcaguaec y con ella Atuguju, estas eran dos cerros muy altos, $y$ a estos mochaban $y$ adoraban para que les diese fuerzas. Relación de la religión y ritos de los indios de Guamachuco, hecha por los primeros religiosos agustinos, que allí pasaron, para la conversión de los naturales, 
Al Anconcagua (aymara, anco $=$ niño tierno, débil; cahua = camiseta, funda, boina), en la Provincia de Hatun Cana, ofrecían muchos sacrificios, no sólo de animales, sino de hombres (1).

Muchos eran los dioses de los Collas, mas, especialmente, reverenciaban a los cerros que llaman Collo o, en plural, Collo-Collo. En la Provincia de Chucnyto, eran los más célebres el Ano-ano (aymara-ano=perro, ano-ano= perros o gran perro) o Don Cararo, el Atucachi $($ quichua - hatun = grande, cachi $=$ sal $)$, el Ccapia (quichua - kapya = blando, relativamente blando), el Pachapagui (quichna-pacha= tierra, paqui = quiebra, esto es: quiebra la tierra) y el Pochpo-collo (2).

Cclección de documentos, inéditos, relativos al descubrimiento. Conquista y Colonización de las posesiones españolas en América y Oceania, publicados por Torres Mendoze, Tol. III, pg. 37, Madrid, 1855.

11) (Anconcagua) estaba pegado a la provincia de Ilatun Cana, y a tiempos iluan de muchas partes con gran veneracion... dicese que sin los muchos animales que sacrificaban a este diablo.... hacian 10 mismo de algunos inclios e indias. Ciezc de León, Segunda parte de la Cronien del Peru, pr. 111, Madrid, 1880.

(2) Muchas cosas arloran los indios pero esjecialmente son dados a la adoración de los cerros, que ellos llaman collo, o collo collo quando son muchos, y tienen sus nombres particulares en cada Provincia. En esta de Chuncuyto es muy celeReligion del Imperio de los Incas 
El favor que en el Onzco lograba esta clase de cultos, no era menor que el que tenía en las Provincias del Imperio, ya que no había menos de diez y seis huacas, que eran montes o colinas, situados en los alrrededores de la cindad.

Principiando por aquellos adoratorios, que había en la dirección de Ohinchansuyo, encontramos que la quinta huaca del primer ceque, era el cerro Sonconancay (sonkon $=$ corazón; cay =el ser la posesión, esto es: el que tiene corazón), en donde hacían sacrificios por la salud del Inca (1).

En el cuarto ceque de Oollasuyo, era la séptima huaca Raraoquirau, (rarzo o, por apócope, $r(t r o=$ cerro nevado; quir $\alpha=$ diente), monte adorado por su tamaño (2).

La novena del mismo ceque era el cerro Sinayba, junto al cual estaba la décima $y$ úl-

bre un cerro que llaman Ano-ano o Don Cararo.... Otro se dize Atucachi, Ccapia, Pachapaqui Pochpo-collo etc. Bertonio, Confesionario muy copioso en dos lenguas Aymara y Española, pg. 250, Juli, 1612.

(1) La quinta 5 postrera huaca deste ceque tenia por nombre Sonconankay es un cerro donde era muy antiguo ofrecer sacrificios por la salud del Inca. Cobo, Historia del Nuero Mundo, Sevilla, 1839, Tol. IT.

(2) La setima se decia Raraoquirau. Es un cerro grande que adoraban por su grandeza 5 por ser sefialado. Cobo, Historia del Nnero Mundo, Serilla, 1889. 
tima del ceque, llamada Sumiurco (sumi ==largo, extendido, urco $=$ monte), a la que ofrecían conchas (1).

La cuarta hnaca del octaro ceque de este mismo camino, era una colina, llamada Chuquimarca (asmara; choke $=$ oro, marca $=$ pueblo), a la que ofrecían conchas molidas (2).

La décimatercia del noreno ceque, era el monte Punco (punco = puerta), al que ofrecían los restos de los sacrificios de las demás huacas (3).

De mayor importancia era Mantocalla (mantay $=$ extender, desplegar $;$ callas $=$ principiar, comenzar), sexta huaca del tercer ceque de Antinsuyo, cerro de gran reneración, en el cual, al tiempo de desgranar el maíz, hacían muchos eacrificios, entre otros, el de haces de leña labrada, restida como lombres

(1) La novena Guaca es un cerro grande llamado Sinay. ba que está de estotro cabo de Quispicanche.

La decima y ultima se decia Sumeurco es un cerro que tenían puesto por límite de las Guacas deste Ceque. Está junto al de arriba, y ofrecianle conchas. Cobo, Op. cit., Tol. IT.

(2) La cuarta era un cerrillo llamado Chuquimarca, que está junto a Guanacauri ofrecianle conchas molidas. Cubo, Op. cit., Vol. IV.

(3) La postrera guaca de este camino era un cerro llamado Punco, a donde ofrecían lo que sobraba de las Guacas deste Ceque. Cobo, Op. cit., Tol. $1 \mathrm{~T}$. 
y mnjeres, $y$ gran cantidad de falsas mazorcas de maíz, hechas de madera. Mas no se limitaban a tan incruentos sacrificios, sa que quemaban muchas llamas y aún se dice, que mataban niños (1).

Muy probable es que Mantocalla haya sido una huaca de gran importancia, en tiempos remotos, cuyas aras se humedecían, a menudo, con sangre humana, y que, andando los tiempos, disminuyendo la importancia de este santuario y suarizándose las costumbres, se sustitayeran los sacrificios de hombres con los de imágenes que los representaban, procedimiento bien conocido, del que hay muchos ejemplos y que en su lugar estudiaremos (2). En la dirección de Continsuyo, notamos que la décimaquinta huaca del octaro ceque,

(1) La sexta se decia Mantocalla que era un cerro en gran veneracion, en el cual, al tiempo de desgranar el mais, hacian ciertos sacrificios, y para ellos ponían en el dicho cerro muchos haces de leña labrada, vestidos como hombres y mujeres y gran cantidad de mazorcas de maiz, hechas de palo; y. después de grandes borracheras, quemaban muchos carneros, con la leña dicha y mataban algunos niños. Cobo, Op. cit., Tol. IT.

12) Frazer, The Golden Bough, Tol. IV. The Dying God, pg. 214 a 280, London, 1914.

Testemarck, The Origin and Developement of the Moral Ideas, Vol. I, pgs. $469 \mathrm{y}$ siguientes. London, 1912. 
era el monte Lluquirivi (1); la segunda del siguiente ceque, Micayurco (mikuy $=$ comer, arko $=$ cerro) (2); la cuarta del décimo ceque, Viracochaurco (Viracocha, urco = cerro) (3); la cuarta del undécimo, Tampuurco (tampu = posada, urco $=$ cerro) (4). Igual número del décimocuarto ceque, era una colina, llamada Pomagnaci (puma =león, guaci $=$ casa) (5).

En el siguiente ceque, estaba Pantanaya (pantay = errar, equirocarse, pecar; na $=$ interjección de duda, ya =exclamación de sorpresa), monte partido por el medio y que dividía el camino de Chinchansuyo del de Oontinsuyo (6).

Ohinchancuay y Quiquijana (quiqui = propio, mismo; kána $=$ hombre ril, desprecia-

(1) La ultima guaca desde Ceque se decia Liuriquiri. Es un cerro grande junto a la quebrada de arriba. Cobo, Op. cit., Vol. IV.

(2' La segunda se llama Micayurco. Es un cerro grande que está encima de Puquin. Cobo, Op. cit., Vol. 1T.

(3) La cuarta Viracochaurco. Es un cerro que está encima de Puquín. Cobo, Op. cit., Vol. IV.

4) La cuarta Tampurco, es otro cerro que está a un lado del de Puquín. Cobo, Op. cit., Vol. IT.

(5) La cuarta Pomaguaci es un cerrillo al cabo deste Ce. que. Cobo, Op. cit., Tol. IV.

(6) La cuarta Pantanaya, es un cerro grande partido por medio, que divide los caminos de Chincha $y$ Condensuyo o Continsuyo. Cobo, Op. cit., Vol. IV. 
ble, enseña que se cuelga a la puerta de la chichería) eran dos montes, que no pertenecían a ningún ceque 5 eran adorados (1).

No era exclusira del Perú, la adoración a las montañas: encuéntrasela en todos aquellos pueblos, que no han llegado a un grado suficiente de erolución, para que desaparezca la creencia en la dirinidad, o, santidad de los montes 5 que tienen en su recindad alguna cumbre notable.

El respeto, que se tributa a un monte, puede presentar dos formas enteramente diferentes, pues ya es teniảo por divino, ya por lugar santo.

La primera concepción, sólo es posible en aquellas religiones, en que no ha asentado aún sus reales el antropomorfismo y en que la deidad no es necesariamente un ser humano, o en aquellas en que un principio de individaalización, ha hecho que se conciba la montaña como un ser, animado por un espírita divino. Esto es propio de las religiones, llamadas animistas $y$ aquello del estado evolutivo,

(1) La tercera se llama Chinchacuay. Es un cerro que esta frontero de la fortaleza. La cuarta y ultima de todas se decia Quiquijana. Es otro cerro que esta detras del de arriba. Cobo, Op. cit., Tol. IV. 
caprichosamente llamado naturalismo (1), caracterizado por la concepción mena, en su mayor pureza, de la cual se origina $y$ en la que se funda la adoración a los montes en su forma más primitiva.

Originada de ella, es también la que hemos dicho animista, voz que, en rigor, puede aplicarse, con igual exactitud, a ambas concepciones (como lo hicimos en el primer capítulo). La úna no es sino el natural desenvolvimiento de la otra, pues, si un sér (un monte en el caso presente), es concebido como impregnado por fuerza activa y misteriosa, conociendo mejor el hombre su modo de obrar y poniéndose por molde $y$ arquetipo de toda la creación, supondrá que la fuerza de dicho ente, es el alma de él.

Mas cuando estas ideas enrejecen $J$, junto a ellas, la constante erolución humana hace que nazcan nueras $\mathbf{y}$ más perfectas doctrinas, el monte-dios ruélrese la morada de los inmortales, el teatro de sus hazañas, el lugar de sus delicias

La montaña ha dejado de ser deidad, para conrertirse en santuario: puede ya su carácter

(1) Clodd, Animism. The seed of Religion, London 1905, pgs., $24-27$. 


\section{Religión del imperio de los İnuas}

sagrado perpetuarse a través de las edades. Revolucionará el mundo, generaciones se sucederán, morirán en el olvido y desprecio los eternos que habitaron en la cumbre, olvidaránse sus nombres, si sus gestas no ocnpan a poetas y artistas, o dan pábulo a galanos ingenios. Mas el monte seguirá siempre siendo objeto de especial respeto para los espíritus sencillos, que duermen bajo su sombra o ven salir el sol entre sus riscos; se contarán de él nuevas historias, fabulosos prodigios de santos, o proezas de demonios, venturas o desgracias, ocurridas entre sus pliegues. El monte siempre será un lugar sagrado, por sus males o por sus dones.

Muy interesante sería para nosotros precisar en cuál de estos dirersos estados evolutivos se encontraba el culto do los montes en el Perú. Los pocos datos, que sobre el asunto hemos encontrado en los antiguos cronistas y que acabamos de examinar, nos autorizan a pensar que, en la mayor parte de los casos, el monte era reverenciado por sí mismo, sin que sea posible precisar si se le dotaba do una alma, o se lo concebía como poseedor de fuerza mágico-religiosa; si bien es muy posi- 
ble fuese así, a juzgar por el concepto que aquellos indígenas tenían de huaca.

En algunas ocasiones, sin embargo, parece muy probable, que el monte haya sido tenido por la morada de un espíritu supremo. A reces, no cabe duda acerca de ésto, como en el Viracochaurco y Pariacaca.

De todas estas diferentes fases del culto a las montañas, sobran ejemplos. Así, para ilustrar el asunto y esclarecer el significado $\mathrm{y}$ valor de su adoración en el Perú, citaremos algunos casos, tomados al azar, en la literatura etnográfica.

Los Bagandas dicen de algunas colinas, que están poseídas por los espíritus de los animales sagrados, y sólo se acercan a estos lugares con gran temor $y$, cuando se ven obligados a ello, por alguna necesidad, después de congratularse con los genios del lugar, que es tabú para el Rey y sus mensajeros (1).

Para los Nandis, es sagrado un monte, situado cerca de Kãpwaven, llamado Che peloi (el cerro al cual los espíritus ponen fuego;) pues dicen que los espíritus de los muertos queman la hierba del cerro, una vez por

(1) Riascoe (J.), The Baganda, pg. 319, London, 1911. 
año. A esta montaña, no se acerca ningún nandi (1).

Los Kayans de Borneo se creen rodeados de muchos poderes inteligentes, algunos de los cuales están estrechamente relacionados con montañas, rocas y cuevas.

Mientras más remota e inaccesible es una región, más son los Toh (espíritus malignos de raguísima personalidad) de ella temidos. Las colinas ásperas o las cumbres de los montes, son las moradas de Toh, poderosos y malignos (2).

En la India, abundan las montañas reneradas; su culto, según un profundo conocedor de la mentalidad popular de aquellas gentes, proviene de que los montes, con sus tupidos juncales, con sus misteriosas cavernas, que parecen la entrada del mundo subterráneo, con los peligros de los precipicios $y$ animales feroces, parecen estar poblados de espíritus malignos (3).

Inmensa era la deroción que los antiguos Indios tenían al Himalaya, presto que decían

(1) Hollis, The Nandi, Oxtord, 1909, pg.

(2) Hose and Mc. Dongall, The Pagan tribes of Borneo, Vol. II, pgs. 16 y 25, London, 1912.

(3) Crooke, Bengal in Hastings Encycloepedia of Ethics and Religion, Vol. II, pg. 482, Edimbourgh, 1909. 
que sólo pensar en él, era más meritorio que practicar toda clase de obras pías en Benares, y que como el sol seca el rocío de la mañana, así los pecados del hombre son borrados por la vista del Himalaya, en donde aseguraban que vivían los dioses.

Desde los tiempos más remotos, el $\mathrm{Hi}$ malaya es el lugar de residencia preferido de los ascetas $y$ todo pico o roca, recuerda a algún varón ilnstre $\mathrm{y}$ recibe el tributo de respeto, debido a su memoria. En las cumbres y cuevas, moran las hadas y las brujas, y en los más altos picos, los dioses.

Toda la cordillera está personificada en la Mitología de la India, por Himarat, padre de Gangâ y Umâ Derî (1).

Mas este culto prevalece entre los pueblos no Aryos, que viren en el altiplano de Ohôta Nâgpur, que adoran a un dios de los montes, llamado Mara - ang Buro o Bar $\mathrm{Pa}$ har, al cual los sacerdotes de la tribu sacrifican búfalos $\mathrm{y}$ otros animales.

Así, entre los Santales, se juntan, ocasionalmente todos los de un pueblo, para ofrecer sacrificios a Mara-ang Buro, en la cumbre

(1) Crooke, Popular Religion and Folk-Lore of Torthem India, Wetsminster, 1S96, Vol. I, pgs. $60 \mathrm{y} 61$. 
348 ReLigión DEL IMPERIO de LOS ÍNOAS

de una montaña, sobre una roca plana; mas no tienen ideas claras acerca del cerro divino (1).

Entre los Hos, es grande la importancia de este dios, cuyo templo es la roca más alta y notable de los alrededores de cada pueblo, siendo su más célebre santuario una montaña, en la que no hay ningana estatua o piedra que sirva de simulacro; invócanlo los enfermos, y su culto público se verifica de tres en tres años (2).

Los Orans, que viven en Mundas, sacrifican a Marang Buro (3).

Los Kisans, consideran sugradas a alganas alturas, por estar consagradas a sus dio$\operatorname{ses}(4)$.

Los Nágbangsis, que viven en un valle mny fuerte, entre los ríos Maini y Eeb, en Jashpur, adoran, así como los Mundari Kols, una

(1) Crooke, Bengal in Hastings Encycloepedia, Vol. II, pg. 482, Edimbourgh, 1909.

Id. Popular Religion and Folk - Lore of Northern India, Wetsminster, 1896, Vol I, pg. 61.

Dalton, Descriptire Ethnology of Bengal, Calcut, 1872, pg. 214.

(2) Dalton, Op. cit., pg. 187.

(3) Id., Op. cit., pg, 257.

(4) Crooke, Bengal, in Hastings Encycloepedia, Vol. II, pg. 482, Edimbourgh, 1909. 
roca, morada del gran dios Baradeo (1). En Jarkwal, en el paso de Chipula, hay un templo, erigido al dios de la montaña; en Tolma, úno, en honor del pico de Dungagiri (2).

Los Kowas y Kurus, adoran a Mainpāt, altiplano situado al sur de Sou (3). Entre Jos Karkus, Dungardeo, el dios del cerro, reside en el monte más cercano al pueblo y le ofrecen sacrificios anuales (4).

En la cordillera de Mirzapur, las tribus aborígenes, tienen gran respeto a los montes (5).

En el cerro de Matrâ, vive un dios o demonio, llamado Darrapat Deo. Nadie sube al monte, excepto el sacerdote $\mathrm{y}$ sólo después de ofrecer sacrificios (6).

Así mismo, en Grarhwal, al pico Bramadeo, consagrado a Devi, nadie puede ascender impunemente (7).

Igualmente celoso de sus dominios, es Sarû Pennû, dios montañés de los Kandhs,

(1) Dalton, Op, cit., pg. 135.

Crooke, Popular Religion and Folk-Lore of Northern India, Westminster, 1886, Vol I, pg, 61.

(2) Crooke, Loco cit.

(3) Id., id.

(4) Id., id.

(5) Crooke, Op. cit., Vol. I, pg. 62.

(6) Id., id.

(7) Id., id. 
al cual rinden culto en los meses de Abril y Mayo, a fin de que proteja de los animales salvajes a aquellos a quienes sus negocios llevan a las montañas de Kandha (1).

En el Mirzapur, Chaimpur, vive Koti Rani, encargado de las langostas, que allí se encuentran (2).

Las cordilleras de Kaimûr y Kindhyan, tienen cierta santidad (3).

En Hoshangâbad, en el altiplano de la India Central, Surybahan, o rayos del sol, es un nombre muy común para rocas o colinas aisladas, en las cuales dicen, que mora un dios (4).

Creen los Todas, que los dioses moran en la cumbre de los montes y que son invisibles a los mortales, mas que los primeros hombres, vivían en estrecho contacto con ellos, en los montes Nilgiri (5).

En China, las montañas son siempre veneradas, como morada de los genios, pero la tradicción religiosa enseña la existencia

(1) Crooke, Bengal in Hastings Escycloepedia, Vol. II, pg. 483, Edimbourgh, 1909.

(2) Crooke, Papular Religion and Folk-Lore of Northen India, Westminster, 1896, Vol. I, pg. 62.

(3) Crooke, Op. cit., Vol. I, pgs. 63 y 64.

(4) Crooke, Op. cit. Vol. I, pg. 61 ,

(8) Rivers, The Todas, London, 1806, jg. 183. 
de cinco cumbres sagradas, más bien ideales que reales (1).

Los Ostayaks, adoran a ciertos montes (2).

Los Koryak, llaman abuelos a determinados cerros, cabos y rocas, de los que aseguran que protegen a los cazadores $\mathrm{y}$ viajeros $\mathrm{y}$ les ofrecen sacrificios. Mas es difícil precisar, si el nombre se dirige al monte o a un espíritu, que suponen lo ocupa, si bien parece más probable la primera interpretación (3). Entre sus recinos, los Kamchadal, existe igual creencia, y señalan entre las montañas sus antecesores petrificados y les hacen sacrificios, en lo que también coinciden con los Koryaks (4). Menos manifiesta está esta idea entre los Chukchee; sin embargo, a un pico que hay en el medio del río Andir, llaman Peru'ten, que es uno de los nombres del dios marítimo Ker'tkan. Ouentan que subiendo éste por el río, cansóse tanto, que se sentó a reposar y se convirtió en una roca (5).

(1) Reville (A.), La religion Chinoise, Paris, 1889, pg. 148.

(2) Tylor, Primitive Culture, Vol. II, pg. 163, Londres, 1891.

(3) Jochelson, The Koryak - The Jesup North Pacific Expedition, Vol. VI, pg. 31, New York, 1905.

(4) Borgas (W.), The Chukchee-The Jesup North Pacific Expedition, Vol. VII, pg. 289, New York, 1907.

.5) Id., id, 
En el folk - lore Yukaghir y en el Alenta, hay muchos ejemplos de cerros que obran como personas vivas y que, al fin de la historia, se asegura se petrificaron (1).

En el país Yosemita, uno de los grandes picos era llamado por el nombre de la heroína mítica, la hermosa Tisayac. Totokomilla, el Jefe del lugar, encontróse en una casa con una muchacha no corporal, el ángel custodio de la localidad, $y$ se enamoró de ella, que no encontró otro medio mejor para escapar de sus amorosos anhelos, que emprender la fuga. Iba ya a alcanzarla su enamorado, tocábala ya casi con las manos, cuando ella desapareció. Vanamente buscóla el Jefe, cuya desesperación anmentaba, al ver degenerar todas las cosas, mal que sólo remedióse, cuando retornó la portentosa muchacha. Mas el Cacique, aleccionado por tan triste experiencia, no trató de volver a ver a la que tanto amaba $y$ se contentó con llamar a uno de los picos de la sierra Tisayac $\mathrm{y}$ a otro Totokomilla (2).

(1) Borgas (W.), The Chuckckee-The Jesup North Pacif Expedition. Tol. VII, pg. 289, New York; 1907.

(2) Dorman, Primitive Superstition, pg. 304. Philadelphia, 1881. La historia de Tisayac recuerda algunos bien conocidos mitos del mundo clásico. de los del tipo de Itzar (Yastrow The Religion of Bitbilonia and Asiria, Boston, 1889), 
Oerca del río Blanco, en una llanura, hay una colina, en la cual dicen los Aricarares, que viven unos espíritus enanos (1).

Los Hidastas reneran a aquellas montañas, quo les parecen extraordinarias (2).

La Montaña de los Muertos, que está en la cabecera del valle Mojare, es rista con reverencia por los indios, porque creen que es la morada de los espíritus de los difuntos y porque dicen que quien la pise, caerá muerto en el mismo instante, en que cometa tan grare desacato (3).

Los Tompson creen que la mayoría de las rocas $\mathrm{y}$ peñascos de forma singular, son hombres del período mitológico, transformados en piedras, y aseguran que son muy numerosos los espíritus de las montañas. Dicen que en las más altas sierras, resile el Hombre Viejo, que forma las lluvias y las neradas.

Por ser la residencia de los espíritus de la tierra, eran tenidos algunos cerros por sa-

I es uno de aquellos mitos en que se quiere explicar el cambio de las estaciones y el renacer de la regetación con la primatera.

'1) Dorman, Loco cit.

(2) Mattheu's (W.), Etnnography and Philology of the Hidasta Indians, pg. 48, Washington, 1877.

(9) Dorman, Loco cit.

Reltigion del Imperio de los Incess 
grados: decían que pisar en ellos, ocasionaba aguaceros, a menos de tomar ciertas precauciones, como la de congratularse con los espíritus, ofreciéndoles sacrificios, como hacían los cazadores, que ofrecían un mechón de pelo, una hilacha del restido, u otra cosa semejante. Para ir a ciertos lugares de éstos, así como a determinados lagos, se pintaban de rojo. Tal hacían, cuando se acercaban a unos picos, de los cuales el central es Amotén, que creen es un hombre, que tieno a sus lados a sns dos mujeres, Ntsêke'lxtin y Séjuk. Dicen que golpear con un palo en esta región, da llusia, lo que igualmente aseguran de otros lugares.

Hay tres rocas, situadas, poco más o menos, a cinco millas al este de Spences Bridge, de las que afirman que son las rergüenzas de su gran transformador, el Coyote y de su mujer (1).

Miny poco diferentes son las ideas do los Lilluets, quienes cuentan muchas fábulas de metamórfosis, relaticas a rocas, que se lallan esparcidas por todo el país, por ellos habitado. En una roca, que so oncuentra en Slaba'-1 o

(1) Teit, The Thompson Indians of British Columbia, The Jesup Nortb Pacific Expedition, New York, 1898-90, Vol. I, Fg8, 337, 338, 341, 344 y 345 . 
Slaka, señalan ciertas pinturas, que dicen ser las de aquellas cosas que se conriertieron en piedras.

Cuando llegan a un lugar de las altas montañas, en que piensan cazar, se dirigen a los picos, diciendo: «Cararemos raíces y cazaremos. Permitid que ni llueva ni haga mal tiempo, os pedimos esto, ob picos!»

Ya hemos risto cómo en Pópesamen todos los pasantes hacen montones de varas, después de flajelarse las piernas, llamando al monte jefe $y$ pidiéndole buen tiempo (1).

En las islas Vancuver, hay un cerro que los indígenas eritan nombrar (2).

Los Hupas tienen dioses, que viren en las montañas, las rocas o los ríos (3).

En Georgia, hay un monte, al cual los indios tenían, antiguamente, supersticioso terror y del que contaban muchas lejendas. Pensaban que había en él un gran puder mágico, que controlaha el mando, desde aquellas hermosas aituras.

(1) Teit, The Lillooet indians. Jesup Ncrth Pacific expedition, Now York, 1906, Vol. II, pg. 279

(2) Lubok, La civilisation primitive, París

(3) Pliny Earle Gordon, Life and Culture of the Hupa-University of California, Archeolngical and Ethnological Series, Vol. I, pg. 77, Berkely, 1903 
En las lejanas y blancas cimas, los indios de las praderas, reconocían la residencia del espíritu, que forma el rayo $\mathbf{y}$ desencadena las tempestades y nunca se atreven a penetrar en tan sagrado recinto, sin ofrecer el debido sacrificio (1).

Para los Apalachitas era sagrado el monte Taimi, en donde había dos grandes carernas sagradas $y$ guardados en ellas vasos emblemáticos llenos de agua, $\boldsymbol{y}$ un gran altar, hecho de nna piedra redondeada, en el que quemaban, continuamente, resinas aromáticas (2).

Los Mejicanos de «todos los montes eminentes, especialmente donde se armaban nublados para llover, imaginaban que eran dioses, y cada uno de ellos hacían su imagen según la idea que tenían de los tales» (3). Oreían que las enfermedades, relacionadas con el frío, tales como el renmatismo, eran dadas por los corros, que, así como tenían poder para causar. las, podían librar de estas dolencias a los que do ellas sufrín, con cuyo fin, hacían sacrificios $y$ ofrendas a tal o cual monte, escogien-

(1) Dorman, Primitive Superstitions, Philadelphie, 1881, pag. 304 .

(2) Dorman, Loco cit.

(3) Sahagún, Historia de las cosas de Nueva Enpana, México, 1829, pga. 35 y 36, Vol. I. 
do de ordinario, aquel que estaba más cerca del doliente.

Este culto, que podemos llamar privado, daba Iugar a ceremonias bastante complicadas, acompañadas, a menudo, de banquetes y diversiones, en que tomaban parte, además de los sacerdotes, los parientes y amigos del enfermo, lo que no podía hacerse sin gastos considerables, entre los que era preciso contar los de la fabricación de las imágenes de los montes, imágenes que eran humanas y representaban a las cumbres pricipales, entre las que figuraban, en Méjico, los volcanes Popocatepetl y Poiantecatl. Fran de masa de bledos, llamadas tzoalli, y fabricábanlas los hechiceros. Ofrendábanles tiras de papel y pegábanlas a úna, para así, suspenderlas del cuello. Cinco días después, se rerificaba la fiesta principal, en que se ofrecía comida y terminaba descabezando los sacerdotes las figurillas (1).

Mas no eran lias más altas cumbres de la cordillera, las únicas que los súbditos de Montezuma adoraban, pues, muy al contrario, las alturas moderadas, aquellas que todo el año están cubiertas de verdura, eran muy reneradas.

(1) Sahagún, Loco cit. 
En la serranía de Méjico, la experiencia había enseñado, que en las montañas llovía aún durante la estación seca y se conservaba siempre lozana la regetación, por lo cual, las tuvieron por moradas de Tlaloc, dios de la lluvia, a quien tánto respeto texían (1).

Así, la bella montaña cónica, siempre verde, situada al Este del territorio tlascalteca, fué tenida por estas gentes, por la residencia o encarnación de Matlalcuey (matlactli $=\mathbf{a z u l ,}$ cueitli $=$ enaguas, ye $=$ tiene; esto es $=$ la senora del restido azul, esposa de Tlaloc). Grande era la reneración que en Tlascala gozaba este monte, semejante tan sólo a la que recibía otra gran montaña, el Tlalpatecatl, pues a ellos acudían todos los pueblos comarcanos, a quemar copal $\mathbf{y}$ ofiendar comidas, papel y plumas (2).

(1) Seler (Ed.), Codex Vaticanus, No. 3773. Codex Vaticanus, B. and Old Mexican Pictorial Manuscript in the Vatican Library, London and Berlin, 1902 a 1903, pg. 106.

(2) Fray Diego Durán, Historia de las Indias de Nueva España y Islas de Tierra Firme, Mêxico, 1880, Vol. II, pg. 206.

Seler, Loco cit.

Robelo, Diccionario de Mitologia Nahua. Anales del Museo Nacional de México, Segunda Epoca, Vol. IV, pg. 187, México, 1907 y Vol. V, pg. 282, México, 1908. 
Uno de los santuarios más famosos del venerado Tlaloc, era un cerro alto, dicho Tlalvean, o lugar de Tlalve, «que está en términos de Coatlychan y Ooatepec. En la cumbre de este cerro, había un gran patio cuadrado y en él un adoratorio, en el cual estaba el ídolo Tlaloc, y, a la redonda, cantidad de ídolos pequeños, que significaban los demás cerros y quebradas, que este gran cerro tiene en derredor, los cuales todos tenían sus nombres particulares, según el cerro que representaban" (1). Oelebraban allí, todos los años, el 29 de Abril, la fiesta Hueitozoztli, en la que sacrificaban un niño $\mathrm{y}$ a la que concurrían gran número de gente $\mathrm{y}$ todos los jefes del distrito. Verificábase esta solemnidad todos los años, cuando el maíz había ya nacido, esto es, al mismo tiempo que en Méjico se celebraba la gran fiesta a los montes, que luego describiremos, $y$ en ella pedíanles buen tiempo (2). co, 1880.

(1) Fray Diego Durán, Op. cit., Vol. II, pg, 135, Méxi-

(2) Fray Diego Durán, Historia de las Indias de Nueva Espana y islas de Tierra Firme, México, 1880, Vol. II, pgs. 135 , a 141 .

Seler (Ed.), Codex Vaticanns, No. 3.773. Codex Vaticanus B. and Old Mexican Pictorial Manuscript in the Vatican Library, London and Berlin, 1902-1903, pg. 106. 
Como acabamos de ver, según los mejicanos, en los montes residía el dios de la lluvia, Tlaloc: lo explica la opinión que tenían, de que ellos eran vasos llenos de agua, que podían romperse y anegar al mando (1).

Mas, si el dios do la lluvia, que lagar tan prominente ocupa en el culto que recibían en Anaua los cerros, aparece como una entidad distinta de la montaña, no así Tepesolotli $($ tepetl $=$ cerro, yolotli $=$ corazón), que residía en el centro de los montes; por lo cual ora tenido, especialmente, por genio do las cavernas, cuga expresión es el humo y que en el Oódex Boloña, está representado con figura humana, pero que en las pinturas mejicanas toma más ordinariamente, la forma de jaguar. Tepeyolotli era el octavo señor de la noche (2).

Ya hemos tenido ocasión de nombrar la mayor parte de aquellos montes, que eran más venerados por los mejicanos. Ahora sólo mencionaremos al Poiantecatl $y$ al Teocnicani

(1) Robelo, Diccionario de Mitología Nahua. Anales del Museo Nacional de México, Segunda Epoca, Vol. V, pg. 226, México, 1908.

(2) Seler (Ed.), Op. cit., pgs. 17 y 57.

Robelo, Op. cit., Vol. V, pgs. 226 y 227. 
(teotl $=$ dios, cuicani $=$ el que canta), que está al Sur del Popocatepetl, al que reverenciaban por las recias tempestades, que se formaban en su cumbre, en donde, muy de continuo, se oía el fragor del trueno. Allí había una casa de descanso y sombra para los dioses, con un ídolo muy rico de jadeíta (1).

A estas cimas, $y$ a todas en general, rendían en Méjico culto solemne, todos los años, en unagran fiesta, llamada Tepeilhuit Teotleco, Pachatoutli, o Ilucpactli y que, al tiempo de la Oonquista, se verificaba en el décimotercio mes, o veintena del año mejicano, por lo cual, para representarlo, "pintaban una cuesta $y$ encima una culebra, la cual cubrían de masa de tamales.... y este diablo se llamaba suchiqueçale y sacrificaban una india» (2).

(1) Sahagún, Historia de las Cosas de Nueva España, Vol. I, pg. 37, México, 1829.

Durdn, Historia de Nueva España y islas de Tierra Firme, Vol. II, pgs. 202 a 207, Nexico, 1880.

Robelo, Diccionario de Mitología Nahua. Anales del Museo Nacional de México, Səgunda Epoca, Vol. pg. 207, México, 1908.

(2) Anónimo, Libro de la vida de que los yndios antiguamente hacian. Roma 1904.- De este precioso manuscrito, con pinturas mejicanas, hay dos ediciones, que reproducen en facsímil el original de Florencia, la uua, liecha a expensas del 
Los ritos que, en esta ocasión, se celebraban, eran públicos y privados, «en honra de los montes altos donde se juntan las nubes y en memoria de los que se habían muerto en agua o heridos de rayos, $y$ de los que no se quemaban sus cuerpos sino que los enterraban" (1) y estaban destinados a establecer entre los dioses de los montes $\mathrm{y}$ sus derotos estrecha alianza, mediante la comunión de las representaciones divinas, en las cuales se consideraba inmanente la deidad: forma de sacrificios muy practicada por los mejicanos y por muchos pueblos primitivos (2).

Para los ritos pricados, servía de hostia una masa de bledos y maíz, preparada, el primer día de la fiesta, con harina recientemente molida, llamada Tzobualli, con la que subrían unos palos muy retorcidos, en una de cuyas extremidades habían labrado, cuidadosamente, una cabeza de serpiente o humana,

Duque de Lubat; la otra, con doctas notas y comentarios, impresa por $D^{a}$. Celia Nuttal, de la que, desgraciadamente, aún no está publicado el Vol. II.

Véase Nuttal, XVII International Congres of Americanistes, London.

(1) Sahagún, Historia general de las Cosas de Nueva E8paũa, Vol. I, pg. 159, México, 1829.

(2) Smith, The Religion of the Semites London, 1914. 
con la que hacían unas imágenes de los mon. tes, la mitad culebras y la otra mitad hombres, fundadas en unos palos, hechos a manera de niñas, que llamaban Ehcantontin. Estas figuras las ponían en el lugar de la casa, que servía de adoratorio, dando, en muchos casos, el sitio preeminente a una mayor que las de. más, a la que llamaban Popocatepetl, disponiendo las ótras a su rededor. Cada una te. nía un nombre, pues representaban, ya a Tlaloc, ya a Ohichocomecoatl, sa a Iztactepel, ya a Amatlecueye, ya a Cihuacuatl o a la señora de los ríos Ohalchichtliycue.

Descansaban los idolillos sobre unas roscas de heno, que guardan de un año para ótro. «En la vigilia lleraban a lavar estas roscas al río o a la fuente $y$ cuando las llevaban íbanles tañendo con unos pitos de barro cocido».

Amasaban los bultillos, ordinariamente, la noche, de manera que estuviosen listos al amanecer. Oolocaban delante de cada monte unos pedazos de la misma masa, rollizos y largos, dichos yonis, y ofrecíanles comida, mazorcas de maíz fresco y copal, mientras les cantaban himnos y dirigían oraciones.

Hacían también unos arbolillos de masa, de los que colgaban heno, para pomeriss ('n 
los cercados, y arrojaban a los cuatro puntos cardinales, maíz de diferentes colores: negro, blanco, colorado $s$ entrererado.

En el segundo día de la fiesta, adornaban los idolillos con mitras $\mathbf{y}$ vestidos de papel, $\boldsymbol{F}$, con gran solemnidad, cual si se tratare de un sacrificio humano, procedían a inmolarlos, sirviéndose de un tztzopaztlil (instrumento de tejer), como del cuchillo de sacrificios, sacábanles el corazón $y$ se lo ofrecían al dueño, quien lo comía y distribuía el resto de la masa entre las personas de su casa, quienes, con gran reverencia, lo tomaban, como a carne de sus dioses, tras de lo cual, comían y bebían, en honor de las deidades muertas.

Mientras esto pasaba en las casas de los particulares, los sacerdotes buscaban on los bosques las ramas más torcidas $\mathrm{y}$ llevábanlas a los templos y las cubrían de masa de bledos, de tal modo que representaren serpientes, con sus ojos y boca. Hacían luégo las mismas ceremonias, que el común de las gentes y fingían matarlas, repartiendo la masa a los cojos, mancos y contrabechos, quienes quedaban obligados a dar la semilla de bledos, para hacer la masa el próximo año.

Al mismo tiempo, no faltaban devotos, 
que iban a la cumbre de los cerros, a encender lumbres y quemar copal.

Los ritos públicos, eran menos inocentes y hamanitarios, que los que acabamos de describir. En ellos había una danza, para pedir buena cosecha; en esta danza remedaban pedir limosna a los dioses. Iban en ella dos esclavas jórenes y hermanas, restidas de papel, en el que habían pintado unos intestinos retorcidos, significando, en el un vestido, la hartura, $\mathrm{y}$ en el ótro, el hambre. Estas muchachas eran luego inmoladas. No eran éstas las únicas víctimas humanas, ya que igual suerto tenían otras cuatro mujeres en los caracteres de Tepechoc, Matlacuac, Xochitecal, Mayahuel, $y$ un hombre, en el de Minahual. Vestían de papel de colores, cubierto de resina elástica, y los lleraban en andas, mujeres, hasta el lugar en que los mataban.

Luego que habían muerto, sacábanles los corazones, para ofrendarlos a Tlaloc. Sus cuerpos los comían los principales señores, $y$ el vestido, que habían llerado, colgábanlo en una sala del templo, en memoria de la festiridad (1).

(1) Sahagrin (Fray Bernardino), Historia General de las Cosas de Nueva España, Vol. I, pge. 35 a 39, 67 a 63 s 159 a 162, México, 1829 . 
En otra época del año, honraban también los mejicanos, solemnemente, a los montes, en el mes de Atemoztli, en que se verificaba la quinta $\mathrm{y}$ última fiesta de los dioses del agua y de los montes. Preparábanse a ella con grandes penitencias, tales como pasarse púas, pajas y cordeles por dentro de la lengua, brazos etc. etc. Hacían, como en la otra solemnidad, figurillas, de los montes de masa de varias semillas, a cuyas figurillas, después de haberlas adorado, abrían el pecho y sacaban el corazón. El cuerpo se dividía por cada cabeza de familia $y$ entre sus domésticos, a fin de que, comiéndolo, se preservasen de ciertas enfermedades, hecho lo cual, quemaban la ropa que habían puesto a los idolillos $\mathrm{y}$ guardaban las cenizas en los adoratorios (1).

Durán (Fray Diego), Historia de las Indias de Nueva España y Islas de Tierra Firme, Vol. II, pgs. 202 a 207.

Torquemada (Juan), Monarquía Indiana, Madrid, 1723, Vol. 1I, pgs. 279 a 280.

Robelo (Cecilio), Diccionario de Mitología Nahua, Anales del Museo Nacional de México, Segunda Epoca, Vol. V, pgs. 36 a 37 y 224 a 226, México, 1908.

Payne, History of the New World called America, Vol. I, pg. 404, Oxfor, 1892.

(1) Rohelo, Diccionario de Mitologia Nahua. Anales del Museo Nacional de México, Segunda Epoca, Vol. II, pg. 360, Méxicd, $190 \dot{5}$. 
Los Chibchas, además de adorar a machos objetos naturales, como a las lagunas, ríos, arroyos y cuevas, reneraban a las montañas (1).

Los ejemplos aludidos, esclarécenos acerca del culto que los peruanos rendían a las montañas, culto que debía encontrarse en un estado de evolución poco inferior a aquel en que se hallaba Méjico; esto es, que no eran tenidas por sagradas, por estar asociadas a una divinidad determinada, de lo que en Méjico hay marcadas trazas, sino por dotadas de un espíritu divino, semejante a Tepesolotli, o por ser receptáculos de mana.

El culto de los cerros en el Perú, quizás, con el que presenta mayor semejanza, es con el que se les tributa por las tribus Salishs y los Ohibchas, similitud debida tan sólo a pertenecer a un mismo grado de erolución.

Fundado en los iguales principios que el culto de las montañas es, a no dudarlo, el de las islas, montes más sorprendentes para los primitiros, cuanto que se lerantan sobre la inmensa 5 misteriosa llauura del mar.

(1) Restrepo, Los Chibchas, Bogttá, 1895, Jg8. 51 y 76. 
Los aborígenes de la Costa del actual Perú, contaban que, en tiempos remotos, habían sostenido una encarnizada lucha los dioses Vichana y Pachacámac, cuyas terribles consecuencias sufrían los hombres, que las celosas divinidades creaban, pero que no protegían contra los ataques de su adversario. Así, decían que, durante una ansencia de $\nabla$ ichana, $\mathbf{P a -}$ chacámac mató a la madre de éste, creando, en seguida, hombres $y$ mujeres, para que poblasen la tierra. Cuando Vichana regresó y se impuso del terrible fin que había tenido la autora de sus días, tuvo tal indignación que, aún después de resucitarla, viendo que Pacbacámac se había librado de su venganza, refugiándose en el mar, «bramando encendía los ayres, e centellando atemorisaba los campos rolvió el enojo contra los de Vegueta y culpándoles de cómplices pidió al Sol su padre los convirtiese en piedras, conversión que luego se hizo.... No uro bien ejecutado el castigo que el Sol i el Vichana se arre. pintieron de la impiedad.... no pudiendo des. azer el castigo quisieron satisfacer el agrario i determinaron dar onra de divinidad a los Curacas y Caciques a los nobles y valerosos, i llevándolos a las costas y playas, los dejo 
a unos para que fuesen adorados, y a otros puso dentro del mar que son los peñoles.... a quien les dicen títalos de deidad, i cada año ofreciesen oja de plata chicha y mollu ..... dando el primer lugar al Curaca Amat, que es un peñol o roca una legua de tierra» (1).

Los moradores de las tierras bajas del Perú, que tenían una civilización tan antigua $y$ original, contaban con reducidos medios de subsistencia, pues la llama, el animal doméstico de más importancia que conocían, aclimátase mal en las regiones calientes, y los áridos campos sólo rendían frutos en los estrechos valles, a los que, merced a ingentes obras de canalización, era posible llerar agua, desdo escasos y torrentosos ríos. La tierra cultivable era escasa; la pesca, si rica y abundante, no podía, por sí sola, satisfacer las necesidades de un pueblo sensual y refinado.

Un cultiro intenso era indispensable, y el aguijón de la necesidad hizo quo la agricultura progresase grandemente, a lo cual con-

(1) Calancha, Chronica Moralizada, Vol, I, ngs. 412 a 414, Barcelona, 1638.

Los mitos de Vichana y Pachacámac serán estudiados al tratar de estos dioses. Ahora nos limitamos a reproducir, sin comentarios, las frases mismas de Calancha. 
tribuyó, de modo poderoso, el guano, que aún hoy constiture la riqueza principal de la costa peruana.

Así, si las islas en sí mismas, eran tenidas por divinas, aquellas, en que existían depósitos de grano, recibían particular adoración, pues, decían quo en éstas había una huaca que lo críaba, y, cuando el maíz iba a espigar, iban en balsas a las islas, llevando mullu, paria, chicha $y$ otras cosas en sacrinicio (1).

(1) Las Islas que en la mar tienen guano con que estercolais el máiz quando quere espigar, no son Dios.

I para que sepais bien esto, aueis de saber que estas Islas son vnos cerros grandes de piedra, que los crió Dios en la mar, para mostrar su Omnipotencia, y alli se han estado desde que Dios crio el cielo, y la tierra, y como por alli vuelan muchos pajaros, que vosutros llamais Huanai, y duermen y estercolean alli, por esso desde lexos están blancas.

Direisme, Padre, los hechizeros nos han dicho, que en estas Islas está vna Huaca, que es criador del huano y quando quie$\mathrm{r}^{\Theta}$ espigar van allá con balsas, y lleuan chicha, mullu y paria, y otras cosas y le piden licencia para traer huano.

A ciegos, sin entendimiento, no vois que el huano es estiercol del pajaro que se llama Huauai, y como el estiercol de las ouejas es bueno para las sementeras, assi de la misma manera el estiercol del pajaro Huauai es bueno para el mayz. Di. me ay alguna Huaca que crie el estiercol de la oueja? No porque las mismas ouejas lo estercolean pues assi de la misma manera no ay Huaca que crie el huano.... Avendaño, Sermones de los Misterios de nuestra Santa Fe, Lima, 1649, fol. 55 \& 57. 
En el preblo de Huacho, cuando debían ir a coger guano en los farallones de Huara, derramaban chicha en la playa, para no tener accidentes en la travesía; antes de emprender el riaje, ayunaban dos días, absteniéndose de ají, sal y mnjeres; y, cuando llegaban a la isla, adoraban a Huamancántac, como a dios del huano, ofreciéndole sacrificios en compensación de lo que le tomaban de sus dominios. De retorno al puerto, ayunaban dos días más y celebraban fiestas, con bailes y cantos (1).

La isla do la Plata era un lugar sagrado para los Mantas y para los Incas, según lo han demostrado las excaraciones de Dorsey (2). Esta hermosa isla no era habitada en épocas prehistóricas, y allá pasaban, de

(1) $Y$ en el pueblo de Huacho quando ivan por Huano a las Islas que son los farallones de Huara, hazian vn sacrificio derramando chicha en la playa, para que no se trastornasen las balsas, precediendo dos días de ayuno, y quando 110 gavan a la Isla adoraban a la Huaca Huamancantac como Sezor del Huano, y le ofrecian las ofrendas para que las dexasen tomar el Huano, $y$ en llegando de buelta al puerto ayunaban dos dias y luego baylaban y cantavan y bevian. Arria. ga, Extirpación de la Idolatria, Lima, 1621, pg. 31.

12) Dorsey, The Island of la Plata, Ecuador. Chicago, 1901. 
tiempo en tiempo, los moradores de la costa a ofrecer sacrificios (1).

Más que temerario sería afirmar que este culto, así como el que se verificaba en las islas Chinchas (2), haya sido tributado a la isla, siendo más probable que la isla se haya considerado sólamente como un lugar santo, grato a las divinidades, y nó un dios, esto es, participaban del mismo carácter y naturaleza que Koati y Titicaca, cusa santidad originábase de los santuarios del Sol y de la Luna, que en ellas había.

(1) (En la isla de la Plata) en los tpos antiguos solian tener los indios de la trra firme sus sacrificios y matauan muchos corderos y ouejas, $y$ algunos niños, $y$ ofrecian la sangre dellos a sus jdolos o diablos la figura de los qlls tenian en piedras a donde adoraun. Cieza, Primera parte de la Chronica del Perú. Sevilla, 1553, fol. 5.

12) Solian los Indios y de la tierra firme a hacer en ellas (las Islas Chinchas) sus sacrificios. Cieza, Op. cit., fol. 6 vuelta. 


\section{CAPITULO V}

\section{ROCAS Y PIEDRAS ADORADAS}

Hemos pasado ya en revista, la adoración de las montañas en el Perú; consecuencia de ésta es, a no dudarlo, la de rocas, galgas y piedras, siendo difícil, por no decir imposible, establecer una diferencia marcada, entre el culto de la montaña cubierta de eternas nieves, la veneración del monte, terminado en agudos picos de negruzcas y despedazadas rocas, la adoración del peñasco, o el culto rendido a una piedra singular por su forma, tamaño o color.

Que el culto de las piedras estaba en vigor, hasta en los últimos días del Imperio y que florecía a la llegada de Pizarro y sus compañeros, no sólo lo sabemos por el unánime testimonio de los cronistas, sino que nos lo demuestran las rocas, evidente objeto de culto, descubiertas en la grandiosa ciudad de Machu- 
Picchu, fortaleza eminentemente incaica, sepultada, quizás, después de las guerras de Manco $y$ sus sucesores, por un espeso bosque, que ha guardado íntegramente la belleza $y$ magnificencia de la vieja fortaleza, hasta hace pocos años en que, fué descubierta por la expedición arqueológica, enriada al Perń, por la Unirersidad de Yale.

Machu - Picchu, está dividido en barrios, independientes unos de otros, teniendo cada uno, lo que puede llamarse, un centro religioso, consistente en una piedra natural, más o menos tabajada, bajo la cual se encuentra una cuera (1). Algunas de estas piedras son intihuatanas (2), monumentos consagrados al culto de los muertos (3). Cerca de la llamada plaza sagrada, donde están algunos de los más admirables edificios de esa maravillosa ciudad, hay una galga con petroglifos, que representan serpientes; otra piedra llera, lo que parece ser, la imagen del sol (4). Cerca de Aban-

(1) Binghan. In the wonder land of Peru. The Geographical Magazine. Washington 1913, Vol. XXIV, pg. 471.

(2) Binghan. Op. cit, $\mathrm{pg}=$. 481, 4S2, 484.

(3) Thle. Zur Deutung der Intihuacana. Wiena 1909, pg. 379 .

(4) Binghen. Op. cit., pgs. 472, 497. 
cay, en Concacha, se encuentra un grupo de rocas trabajadas, mus notables (1). Cerca de Viticos, en Nusta, España, hay una gran peña, rodeada de un templo, en el que se encuentran varias piedras, trabajadas a modo de sillones (2).

En los mitos cosmngónicos, Viracocha crea a los hombres $y$ por una desobediencia de éstos, los convierte en piedras, estatuas que se veían hasta los últimos años del Imperio, en Tiahuanaco; según otra rersión de la leyenda, son las esculturas do Tiahnanaco, los proto tipos de los hombres que Viracocha $y$ sus ayudantes, debían crear para poblar la tierra, hechas por el Dios, para que sirviesen de modelo (3). En la lucha de Vichana y Pachacamac, los hombres que crea el un dios, el otro los convierto en piedras (4). Ayar Cachi, al decir de nnos, Asar Uohu, según otros, se transforma on el ídolo Guanacauri, piedra

(1) Binghan. Op. cit., pgs. 536, 537, 539.

(2) Binghan. Op. cit., pgs. 551, 554.

(3) Molina. Ritos y Eábulas de los Incrs. Colección de libros y documentos referentes a la Historia del Perú, Tol. I, Lima 1916, pgs. 6 a 10.

(4) Herrera. Historia de los Hechos de los Castellatos en las Islas, Tierra Firme y Mar Océano. Década Quinta, Madrid 1728, pg. 62 . 
muy venerada por los Incas (1). Manco Oapac corre igual suerte (2).

«Estas transformaciones en piedras, dice T'schudi, y la creación de nuevos hombres, sacados de la misma piedra, llama tanto la atención, que justifican ampliamente la hipótesis de un culto intensivo de la piedra, entre los antiguos peruanos, así como una antropomorfización de las piedras, en hombres animados. Al principio, las piedras eran objeto de adoración; después tuvieron su leyenda, su historia, en las que iban apareciendo, poco a poco, a manera de figuras de hombres, a los que, más tarde, levantaron estatuas (3).

¿Veneraban los antiguos peruanos a las piedras, por creer eran en sí mismas deidades, o por ser el receptáculo de la fuerza mana, la reliquia preciosa de nna divinidad, su imagen, o altar? Esto es lo que trataremos de

11 Calancha. Chronica Muralizata. Barcelona 1638, 1)gs. 412, 414.

(2) Ondegardo. Los errores y superticiones de los Indios. Confesionarios para Curas de Indios, Lima 1585, fol. 8 vuelta.

(3) Tschuli. Contribuciones a la Historia, Civilización y Lingüistica del Perú Antiguo, Tomo II, pgs. 202 y 203. Cclección de libros y documentos, referentes a la Historia del Perú. Vol. X, Lima 1913. 
precisar, siguiendo el método que bemos empleado en los capítulos anteriores.

Principiaremos nuestro examen, por aquellas piedras huacas, que se veneraban en el Cuzco y que estaban, digámoslo así, incorporadas con el plauo de la metrópoli del Imperio y a las que se les rendía culto oficial, público.

La sexta huaca, del segundo ceque de Ohinchaysuyo, era una piedra grande, que el Inca Yupanqui colocó en Chuquibamba y a la que, por su orden, se hacían sacrificios, rogando conservase la salud del Inca reinante: llamábase Macasayba (1).

Igual origen tenía Molloguanca, (mullu= concha, huanca = galga, peñón); piedra que estaba en medio de un llano y que era la sexta huaca, del tercer ceque de Ohinchaysuyo (2).

(1) La sexta Guaca, se decía Macasayba; era una piedra grande que Inca-Yupanqui puso junto al llano de Chuquibamba y mandó le hiciesen veneración y sacrificios, por la salud del Rey.-Cobo. Historia del Nuevo Mundo, Sevilla 1892, Vol. IV. Parece que esta huaca debió ser más antigua que el Inca Yupanqui, pues su nombre no pertenece a la lengua quichua, ni a la aymara.

(2) La sexta Guaca, se llamaba Molloguanca, era cierta piedra que estaba en medio de un llano, que llaman Calispuquio, la cual mandó poner allí y tenerla por adoratorio Inca Yupanqui. Cobo. Loco cit. 
La sexta huaca, del cuarto ceque de la misma dirección, decíase Oollaconcho (aymara colla $=$ purga, comida o bebida, emplasto, medicina, bebedizo o ponzoña, concho precipitado de un líquido, hez del rino de la chicha) conocida hoy con el nombre de la "piedra canzada (1), es un canto yerático, que está en las inmediaciones de la fortaleza de Sacsahuamán y que recuerda, por su forma, los resbaladeros, de que ya tendremos lugar de ocuparnos, al tratar de las supersticiones relativas a las piedras del Viejo Mundo y especialmente de Francia. Acerca de Collo - concho, contaban los indios, que trayéndola para la constracción de la fortaleza, rodó tres reces, matando a algunos indios, por lo cual los hechiceros consultaron el caso con la piedra, la que les manifestó su firme propósito de no morerse del lugar en que se encontraba. El

(1) Entre los prodigios que precedieron al fin del reinado de Montezuma, cuentan de una piedra que no quiso ser llevada a México, para servir de piedra de los sacrificios y que después de haber dado varias muestras de vida, rompió un puente de la calzada y se precipitó en la laguna, de donde, durante la noche, se volvió al lugar de su origen, lo que motivó el que se le hiciesen sacrificios. Robelo. Diccionario de Mitologia Nahua; Anales del Museo Nacional de Néxico, II Epoca, Vol. V, México 1907 , pgs. $333-334$. 
culto de esta roca, debe remontar a un período anterior, al del señorío de los Incas (1).

Ohachacomacay (chachay $=\mathrm{feo}, \quad k o y=$ dar, makay =aporrear, pegar, feo dar porrazos) era una piedra que estaba junto a unos árboles, a la cual sacrificaban, porque el Inca no tuviese ira. Pertenecía al mismo ceque que la anterior y era la séptima huaca de él (2). En el séptimo ceque de la misma dirección, era la tercera huaca, Marcatampu (mar$c a=$ pueblo, $t a m b o=$ posada ; posada de la población) eran unos cantos arredondeados, que estaban en Oarmenga $y$ a los que sacrificaban niños, por la salud y conserración del Inca. Su culto fue instituído por el Inca Yupanqui, que al parecer, era muy devoto de las piedras (2).

(1) La sexta Huaca, era una piedra grande llamada Collaconcho, que estaba en la fortaleza, la cual afirman, que trayéndola para aquel edificio, se les cayó tres veces y mató algunos indios, y los hechiceros en preguntas quele hicieron dijeron haber respondido, que si porfiaban en querella poner en el edificio, todos habrian mal fin, allende que no serían parte para ello; y desde aquel tiempo fue tenida por guaca general, a la cual ofrecían por las fuerzas del Inca.-Cobo. Loc. cit.

(2) La séptima Guaca, se decía Chachacomacay: eran ciertos árboles puestos a mano junto a los cuales estaba una piedra, a quien hacian sacrificio, purque el Inca no tuviese ira. Cobo. Loc. cit.

(2) La tercera Guaca, se decía Marcatampu: eran unas piedras redondas, que estaban en Carmenga, donde alıora es 
Toxanamaro (Toxan=el lugar donde estaban; amar $u=$ serpiente; la serpiente de Toxán ) eran cinco piedras arredondeadas, cuyo culto, se decía, fue establecido por el Inca Viracocha, y que se encontraban en la cumbre del cerro de Toxán; ofrecíanle mullu, para que el Inca fuese siempre victorioso; figuraban como la cuarta huaca, en el séptimo ceque de Ohinchaysuso (1).

La huaca siguiente, del mismo ceque, era Urcoslla amaru (Oreo $=$ monte; lla = partícula que se pospone en los nombres, dando así muestras de ternura, amor, afición, gusto; amaru= serpiente; serpiente del montecito) asinamiento de piedras, que estaban en una colina sobre Oarmenga, a las que sacrificaban por la salud del Inca (2).

la parroquia de Santa Ana, las cuales señaló por adoratorio principal Inca Yupanqui. Ofreciansele niños, por la salud $\mathrm{y}$ conservación del Inca. Cobo. Loc. cit.

(1) La cuarta, se llamaba Toxanamaro; eran cinco piedras redondas, que Viracocha Inca, mandó poner en el cerro de Toxán, que está encima de Carmenga. La ofrenda que le daban, era solamente de conchas partidas. Rogábase a esta guaca, por la victoria del Inca. Cobo. Loc. cit.

(2) A la quinta Guaca deste Ceque, Llamaban Crcoslla amaro, eran muchas piedras juntas, puestas en un cerrillo que está encina de Carmenga: haciansele sacrificios por la salud del Inca. Cobo. Loc. cit. 
Yuyotuyro, eran cinco piedras paradas, cercanas a Apuyavira, que decían ser uno de los compañeros de Guanacauri, que con él salieron de la tierra y transformado como él en una piedra. Estaba en el cerro de Piccho y era la décima huaca, del noreno ceque de Chinchaysuyo (1).

Acerca de Pillolliri, contaban, que había estado en otro cerro $y$ que dió un salto $y$ se colocó en el que llevaba el nombre de esta piedra, que por eso era adorada, siendo la huaca siguiente a la anterior (2).

En Antinsuyo, la undécima huaca del segundo ceque, era Quiscourco, (kisqui=estrecho, lleno, repleto, urko = monte); piedra redonda de pequeñas dimensiones (3).

A Pachatosa (pach $a=$ la tierra, el mundo, tusa = pilar de madera, que sostiene el techo),

(1) La décima se llamaba Iuyotuyro; eran cinco piedras juntas que estaban junto al cerro de arriba. Cobo. Loco cit.

(2) La undécima era una piedra dicha Pillo lliri, que cuentan los indios haber saltado de otro cerro a aquel que se llama asi, $y$ por esta imaginación que tuvieron la adoraron. Cobo. Loco cit.

(3) La postrera Guaca deste Ceque se decia Quiscourco: era una piedra rodonda no muy grande que servía de termino y mojón destas Guacas. Cobo. Loc. cit. 
rendían culto, quemando los sacrificios sobre ella (1).

En Chusacachi, (chusay =estar ausente de la casa, ausentarse, viajar; cachi= sal?) que era un monte, habían unas piedras, que eran huacas del segundo ceque de Antinsuyo (2).

La novena huaca, del segundo ceque de Antinsuyo, era Oascasayba, adoratorio muy importante, en el que sacrificaban niños.

Cascasayba (aymara, cccece=acongojado, lleno de cuidados; ccacca = tartamudo, fantasma nocturno, que hace ruido como un tartamudo; suyhud =el mojona) eran unas piedras, acerca de las cuales contaban un largo mito, en el que quizás figuraba el espectro ccacca, del folk-lore aymara, evidonciando así, la antiguiedad de este culto $y$ el primitivo dominio aymara, de la región que fue cabeza y centro de la expansión quichua (3).

(1) La segunda Graca deste Ceque (20 de Antinsugo) se llamaba Pachatosa, era una piedra grande que estaba junto a la casa de Cayo (Don García Cayo Tupac, hijo de Hayna-Capac). Quemábase encima della el sacrificio y decian yue lu comia. Cobo. Loc cit.

(2) La tercera Guaca se decía Chusacachi: es un cerro graude, camino de los Andes, encima del cual estaban ciertas piedras que eran adoradas. Cobo. Loc. cit.

(3) La novena llaman Cascasayba eran ciertas piedras quo estaban en el cerro de Quisco. Era Guata principal y te. 
Cerca de Mantocalla, había un cerro llamado Curi-urco (kori=oro; orko=cerro) en el que habían unas piedras, que eran la primera huaca, del cuarto ceque de Antinsugo (1). En el mismo monte estaba Oallachaca ( $k^{\prime}$ alla $=$ desnudo; chaca $=$ pierna $)$ que eran varias piedras (2).

Protectoras de la salud de los que entraban en los bosques orientales, eran unas piedras que estaban sobre el monte llamado Illansayba (aymara illa=cosa preciosa, que se guarda, reserva, provisión; $n a=$ partícula, de genitivo; sayhua = él, mojona (3).

Sauaraura era una piedra, que estaba en el pueblo de Yacomora y le ofrecían conchas (4).

nía cierto origen largo que los indios cuentan. Ofrecianle de todas las cosas, y también niños. Cobo. Loc. cit.

(1) La primera se llamaba Curiurco y era un cerro que esta cerca de Mantocalla, encima del cual habia ciertas piedras que eran reneradas $y$ les ofrecian ropa $y$ carneros manchados. Coba. Loc. cit.

(2) La tercera Guaca se decía Calla-cacha, eran ciertas piedras puestas en el mismo cerro. Cobo. Ioc. cit.

(3) La sexta Guaca (del cuarto ceque de Antinsuyoj se decia Illansayba: era cierto cerro encima del cual habian unas piedras a que sacrificaban por la salud do los que entraban en la pruvincia de los Andes. Cobo. Loco cit.

(4) La tercera (del ceque siguiente) se decía Sanaraura, era una piedra redonda que estaba en el pueblo de Yacomora; ofrecianle solo conchas, unas enteras y otras partidas. Cobo. Isoco cit. 
Pachacuti Yupanqui, estableció el culto de unas piedras, dichas Runtuyan (runtu= el huevo; $y(a=\mathrm{ah} !)(1)$.

La décima huaca, del quinto ceque de Antinsuyo, era una piedra llamada Pomavico (puma = leoncillo de América, felix puma; huekay = vaciar las tripas volteándolas, para limpiarlas) (2).

En el ceque siguiente, era la segunda huaca, Comorilca (aymara, kumu= corcovado; willia = sagrado, dios huaca) era una piedra corva, a la que ofrecían mullo (3).

En la plaza de Colca-pampa (kollca $=$ el granero, el troje; pampa=llanura) había una piedra, en cuyo honor sacrificahan niños (4).

1) La norena se decia Rondoya (Runtuyan) eran unas piedras que estaban en el cerro asi llamado; púsolas el Inca f'achacutic y mandó las adorasen. Cobo. Loco cit.

(2) La décima y última Guaca deste Ceque era otra piedra llamada Pomarico que estaba puesta por fin $y$ término de las Guacas deste Ceque. Cobo. Loco cit.

3) La segunda Gruaca era una piedra corva, llamada Comorilca que estaba cabe Callachaca, ofrecianle solo concha. Cobo. Loc. cit.

(4) La cuarta era una plaza grande llamada Colcapampa, donde se hizo la parroquia de los mártires, al cabo de la cual estaba una piedra que era idolo principal a quien se ofrecian niños con lo demás. Cobo. Loc. cit. 
Junto al manantial sagrado de Pirquipuquio, habían unas piedras, a las que ofrecían ropa pequeña y corderillos hechos de conchas; llamábanse Cuipanamaro (quepa $=$ trompeta, amaro = serpiente (1).

Sauaraura, eran tres piedras, que estaban en el pueblo de Larapa (2).

En el mismo lugar, había una piedra llamada Urcopuquio, $($ orko $=$ monte; pujyo $=\mathrm{ma}$ nantial, fuente) ofrecíanle ropa de mujer y pedazos de oro (3).

La octava huaca, del octaro ceque, era Cuipan (quepa $=$ trompeta) ofrecíanle conchas coloradas, por la salud del Inca. Esta huaca estaba formada por seis galgas (4).

Picas, (peka $=$ mosto de la chicha) era una piedra pequeña, a la que ofrecían bolitas de oro,

(1) La tercera (Del octavo ceque) se llamaba Cuipana. maro: eran unas piedras junto a este manantial, $J$ eran teni. das por Guaca principal. Ofrecianle ropa pequefia y corderillos hechos de conchas. Cobo. Loc. cit.

(2) La quinta se decia Sauaraura, eran tres piedras que estaban en el pueblo de Larapa. Cobo. Loc. cit.

(3) La sexta se llamaba Urcupuquio y era una piedra erquinada que estaba en el rincón de dicho pueblo. Tenianla por Guaca de auturidad y ofrecíanle ropa de mujer pequefia y pedazuelos de oro. Cobo. Loc. cit.

(4) La octaba se llamaba Cuipan: eran seís piedras que estaban juntas en el cerro asi llamado. Ofrecían a esta Guaca sólo conchas coloradas por la salud del Rey. Cobo. Loic, cit. 
para que no hubiese tempestades de granizo. Estaba en un cerro encima de Larapa (1).

La última del mismo ceqne, era Pilcourco $($ pillco $=$ pájaro colorado $;$ orko $=$ cerro $)$ huaca muy importante, a la cual, cuando so coronaba un nuero Inca, sacrificaban una mnchacha menor de doce años (2).

En el último ceque de Antinsuyo, estaba la huaca Churucana (asmara, churukhana= aquel restitusó) (3).

Gran importancia en la economía del universo tenían otras tres piedras, que estaban en un cerro pequeño, sin cuso poder, el Sol, dios, jefo de la dinastía $y$ sostén del Imperio, perdería sus fuerzas, por lo cual a esta huaca, que tenía el mismo nombre que la anterior $\mathrm{y}$ pertenecía al primer ceque de Collasuyos, sacrificaban niños (4).

(I) La décima se decía Picas: era una pedrezuela pequeTa que estaba en un cerro encima de Larapa, a la cual tenian por abogado del granizo. Ofrecianle demás de lo ordinario pedazuelos de oro pequeños y redondos. Cobo. Loc. cit.

(2) La undécima y última Guaca deste Ceque se llamaba Pilcourco era otra piedra a quien hacian gran veneración, la cual estaba en un cerro grande cerca de Larapa. Cuando habia Inca nuevo le sacrificaban demás de lo ordinario una muchacha de doce años abajo. Cobo. Loco cit.

(3) La cuarta Guaca eran unas piedras llamadas Churo. cana que estaban encima de un cerro más abajo. Cobo. Loc. cit.

(4) La tercera guaca se decia Churucana. Es un cerro fequeso y retondo oque esté junto a San Lazaro; entima del 
Gramansuri (huaman =halcón, suri $=$ avestruz. Según Urteaga, $\operatorname{sir} a o=e l$ hábil en dichos y sentencias, también el hacendoso) (1), era una piedra grande, a la que sacrificaban por la fuerza del Inca, ofreciéndoles ropa pequeña, oro y plata (2). Según las creencias de los Indios de Huamachnco Guamansiri, era nn dios, creado por Ataguju, que vivió pobre $y$ desconocido en la tierra $y$ fne ajusticiado $y$ quemado su cuerpo por los guachemines, por haber seducido a la hermana de éstos, Oantaguán, la que dió a laz dos hueros, de los que salicron Catequil y Piguerao (3).

Tninourco, sexta huaca del segundo ceque de Collasuyo, eran tres piedras juntas, que estaban en el pueblo de Cacra (4).

cual esta tres piedras tenidas por idolos. Ofreciaseles lo or dinario y tambien niños para efecto qua el Sol no pordiese sus fusrzaz. Co3o. Loc cit.

(1) Informaciones acerca de la Religićn y gobierno de los Incas. Lima 1918, nota 10, pg. 14.

(2) La setima guamsari era una piedra grande que estaba encima de un cerro junto a Angostura. A esta guaca sacrifcatan todas las familias por las fuerzas del Inca, $\exists$ ofrocianla ropa pequeña, oro, y plata. Cobo. Loc, cit.

(3) Relación de idolatrias en Hnamachuco por los primeros agustinos. Informaciones acerca de la Religion $y$ Gobierno de los Incas. Lima 1918, pg6. $14 \mathrm{~g} 20$.

(4) La sexta se nombraba Tinourco eran tres piedras quo estaban en un rincón del pueblo de Cacra. Cobo, Loc cịt. 
En la que fue casa de Manso Sierra Leguisano, el famoso conquistador que jngó el sol en una poche y autor de un testamento cual no lo habría escrito Las Casas, habían tres piedras, que eran hnacas, llamadas Tampucancha, (tumpu=posada, cancha=patio) (1).

Pampasona ( $p a m p a=$ llanura, suna=boca) era otra piedra adorada, que estaba junto a las anteriores (2).

En el pneblo de Sano, habían tres piedras redondas, a las que sacrificahan niños; llamábanse Sanopampa (llanura de Sano; Sano, quizás del aymara sano-sano una hierba.) (3).

En Cuipán (quepa = trompeta) monto recino a Guanacaure, habían cinco piedras, en cuyas aras se inmolaban niños (4).

(1) La primera se llamaba Tampucancha. Era parte de la casa de Manso Sierra, en que había tres piedras adoradas por idolos. Cobo, Loc. cit.

(2) La segunda guaca era una piedra llamada Pampaso. na que estaba junto a la sobredicha casa. Ofrecianle conchas molidas. Cobo, Loc. cit.

(3) La septima (del $3^{\text {er }}$ ceque de Collasujo) Sinopampa (Sanopampa?) eran tres piedras pequeñas que estaban en un llano en medio del pueblo del Sano. Sacrificabanle niños. Cobo. Loc. cit.

(4) La cuarta (de 4 ceque) era un cerro por nombre Cui. pan questa destotra parte de Guanacauri; encima del cual estaban cinco piedras tenidas por Guacas. Sacrificabanles todas las cosas especialmento niños. Cobo Loc. cit. 
Si a Catonge, piedra que estaba en lo que fue casa de Juan de Suria, no sacrificaban niños, en memoria de la época en que sangre humana le era acepto sacrificio, le ofrecían figurillas pequeñas de hombres $\mathrm{y}$ mujeres, hechas de oro $y$ plata (1). A no dudarlo, estas imágenes eran de aquellas que se han es contrado en los monumentos incaicos $y$ que admiran por lo perfecto de su labor (2).

Quintiamaro (kénti=colibrí, picaflor, ama. $r o=$ serpiente-Serpiente picaflor; compárese Quezatcoatl), eran unas piedras redondas, que figuraban como huacas, en el quinto ceque de Oollasuyo (3).

Junto a las anterinres, estaba la piedra Cicacalla (tica = ramo de flores, calla $=$ el palo de la rueca) en cuyo honor quemaban ropa y ofrecían conchas (4).

(1) A la primera (del 5 ceque) nombraban Catonge. Era una piedra que estaba cabe la casa de Juan Soria. Adorabanla como a Guaca principal y ofrecianle de todo, particularmente figuras de hombres y mujeres pequeñas de oro y plata. Cobo. Loc' cit.

(2) Larrea y Jijón. Un cementerio incásico en Quito y notas acerca de los Incas en el Ecuador. Quito 1918, Lam. XL.

(3) La tercera se decía Quintiamaro. Eran ciertas piedras redondas que estaban en el pueblo de Quijalla. Cobo Loc. cit.

(4) La cuarta se decía Cicacalla. Eran dos piedras que estaban en el mismo pueblo de arriba. Ofrecianle conchas pequenas y ropa quemada. Cobo. Loc cit. 
Al mismo grupo, pertecían las cinco piedras, que formaban la huaca Ankasmaro (an. kas $=$ azul, amaro $=$ serpiente) (1).

Ofrecían niños a las tres piedras que estaban en el llano de Intipampa (inti $=$ el sol, pompa =llanura) (2).

En Tokaras $($ toko $=$ el agujero, $k a r a y=$ dar de comer) cerro que está frontero de Quijalla, habían tres piedras, a las que hacían igual sacrificio (3).

En la cumbre de Omotourco (Umutu=pequeño, orko $=$ cerro) habían tres piedras que eran huacas (4).

En el pueblo de Membrilla, estaban unas piedras, llamadas Mamacolla (nama=madre, koll $a=$ páramo, koy a reina.) (5).

A nna piedra rodeada de cuatro peque-

(1) La quinta Guaca se nombraba Ancasmaro. Eran cinco piedras que estaban en el mismo pueblo. Cobo. Loc. cit.

(2) La octara se llamaba Intipampa. Era un llano junto a Cacra, en medio del cual estaban tres piedras. Era adoratorio principal, en que se sacrificaban niños. Cobo, Loc. cit.

(3) La sexta (del 50 ceqne de Collasuyo) Tocaray, era un cerro que está frontero de Quijalla. Habia en el tres piedras reneradas: sacrificabanles niños. Cobo, Loc. cit.

4) La décima y última era un cerro pequeño llamado Omoturco, que esta en la puna o páramo. Encima dél estatan tres piedras a las cuales of recian sacrificios. Cubo. Loc. cit.

(5) La segunda guaca (del sexto Ceque). Eran ciertas piedras que ostaban en el pueblo de . Kembrilla. Cobo. Loc. cit. 
ñas, llamaban Quiracoma (quiru=dientes, $c u$ ray $=$ ahora - actualmente $-q u i r a y=$ acostarse, cunan $=$ ahora, actualmente) (1).

Viracocha cancha (patio de Viracocha) eran cinco piedras, que estaban en el pueblo de Quijalla (2) ¿El antiguo templo de Viracocha, en ese pueblo, del que quedaban pilares semejantes a los de Tiahuanaco?

Cuipán (quepa $=$ trompeta) eran tres piedras adoradas (3).

De menos importancia, era la buaca Quiquijana, a la que solo sacrificaban conchas $y$ ropa, quemándola; eran tres piedras, en la cúspide de un cerrito (4).

Chachaquiray (aymara, $\operatorname{chach} a=$ varón, marido, varonil, quira= las varas con que cruzan las tijeras de las casas) era otra piedra, a la que daban culto (5).

(1) La cuarta Quiracona. Era una piedra con cuatro pequeñas que estaban en el llano de Quicalla. Cobo. Loc. cit.

(2) La quinta se llamaba Viracochacancha. Eran cinco piedras que estaban en el pueblo de Quijalla. Cobo, Loc. cit.

(3) La sexta se decía Cuipán, y eran tres piedras puestas en el llano de Quicalla. Cobo. Loc. cit.

(4) La novena se decia Quiquijana. Es un cerrillo pequeno donde estaban tres piedras. Ofrecianles solo conchas y ropa pequeña. Cobo. Loc. cit.

15, La tercera era otra piedra llamada Chachaquiray, que estaba lejos de la arriba (Cotacalla uno de los Pururancas, Cobo, Loc. cit. 
En el octavo ceque, había un pilar de piedra, llamado Madea, al que ofrecían mullu (1).

En el monte Ouicosa, habían otras tres piedras, que eran huaca (2).

En Tampurilca (tambo = posada, huilca $=$ ídolo) habían cinco piedras, que decían haber aparecido allí, a las que quemaban cestos de coca (3).

Quillo, (aymara, kellu= choclo) eran cinco piedras, que estaban sobre el cerro del mis. mo nombre (4).

La undécima huaca, del noveno ceque de Collasuyo, se decía Oachaocachiri (aymara, cach $a=$ varón, marido, $u c a=$ pronombre demostrativo, cachi = corral de carneros) «Eran tres piedras que estaban en un cerrrito llamado así; era adoratorio antiguo en el cual se

(1) La tercera se decía Mudea. Era un pilar de piedra que estaba en un cerrito cerca a Membrilla. Ofrecianle solo conchas. Cubo. Loc. cit.

(2) La quinta se decía Cuicosa. Eran tres piedras redondas que estaban en un cerro llamado asi junto a Guanacauri. Cobo. Loc. cit.

(3) La qninta se nombraba Tampuvilca. Era un cerro redondo que esta junto a Membrilla, encima del cual estan cinco piedras que cuentan haber aparecido alli $y$ por eso las veneraron. Ofrecianles lo ordinario, especialmante cestos de coca quemados. Cobo. Loc. cit.

(4) La decima Quillo, eran cinco piedras puestas encima de un cerro deste nombre cerca de Ginanaccuri-Cobo. Loc. cit. 
sacrificaban niños» (1). El remoto origen de esta huaca, está atestiguado por el origen aymara de su nombre.

Quiquil era una piedra que estaba on una pared, junto a Coricancha; era quizás uno de los Pururaucas, que ayudaron a los Incas en su lucha con los Canchas; pertenecía al primer ceque de Contisuyo (2).

En una quebrada estaba Huamán (huclmán=el halcón) piedra pequeña, redonda (3).

Chataguarque (chatay=acusar, huarcu= pesa) «era cierta piedra que estaba en un cerrillo» (4).

Sacrificaban niños a la piedra Anahnarquehuamán (Anahuarque, nombre de un cerro sagrado ; huamán=alcón ; ana =lunar, grano, huarín=peso [?]) (5).

«La décima cuarta huaca, del primer ceque de Ountisuyo, era cierta piedra llamada

(1. Cobo. Loc. cit.

(2) La segunda guaca era otra piedra como esta, llamala Quinquil, que estaba en una pared junto a Coricancha. Cobo. Loc. cit.

(3) La quinta Guaman, es una quebrada, donde estaba una piedra pequeña redonda que era idolo. Cobo, Loc. cit.

(4) Cobo Loc. cit.

(5) La decima Anahuarqueguaman era una piedra que estaba en un cerro junto a ́́l de arriba: ofrecianle niños. Cobo. Loc. cit. 


\section{Religión del IMPERIO DE LOS Ixcas}

Puntuguanca que estaba encima de un cerro deste nombre cerca del cerro de Anarguarque» (1).

En el camino de Pomacancha, habían tres piedras adoradas, cuyo nombre era Quiguán (kehua $=$ Jerba, planta, mata, kehui=desaseado, kehui = torcido, tortuoso) (2).

Pillochuri (pillu=corona, guirnalda, kori= oro) era huaca del segundo ceque de Oontisuyo (3).

Las cinco piedras que estaban en el monte Caquiasararaura, eran hnaca (4).

"La tercera Cayascasguaman, era una piedra larga que estaba en el pueblo de Cayascas» (5) (el halcón de Cayascas).

"Amarocti, eran tres piedras quo estaban en un poblezuelo llamado Aytocari» (6) (ama$r u=$ serpiente).

(1) Cobo. Loc, cit.

(2) La postrera guaca se decía Quiguan. Eran tres piedras que estaban en su portezuelo camino de Pomacancha. Cobo. Loc. cit.

(3) La segunda se decía Pillochuri. Era una quebrada camino de Tambo en que habia una piedra mediana y larga tenida en veneración. Cobo. Op. cit.

(4) La segunda (del tercer ceque de Contisuyo) se decía Caquiasavaraura. Es uu cerro frontero de Cayocache, encima del cual estaban cinco piedras tenidas por ídolos. Cobo. Loc. cit.

(5) Cobo. Loc. cit.

(6) Segunda huaca del cuarto ceque de Contisuyo. Cubo. Loc. cit. 
Ohuracana (aymara, churakhana =aquel restituyó) era huaca de importancia, pues en sa honor inmolaban niños (1).

«La tercera (huaca del quinto ceque de Contisuyo) Cayallacta eran ciertas piedras que estaban en un cerro cabe Choco, paeblo que fue de Hernando Pizarro" ( $K^{\prime} a y a=$ pasado mañana, después, k'aya huata $=$ el año siguiente, llacta $=$ tierra, país).

Ouando los cuatro Ayares, salieron de $\mathrm{Pa}$ caritambu y llegaron al Ouzco, uno de ellos, Ayar Cachi, dio muestras de tal fortaleza, que los hermanos resolvieron deshacerse de tan poderoso compañero, dando así principio, a la que algunos quieren, pacífica, justiciera domi . nación de los Incas, que revirió la Arcadia y realizó el ensueño de la Edad de Oro y el de la república platónica. Una de las proezas del que después fue ídolo de Guanacauri, que in. dujo a sus hermanos a concter el fratricidio, fue el que con una piedra que disparara con su honda, desmoronó una montaña. Eran qui-

(1) La cuarta Churacana, era cierta piedra grande que estaba en un cerro junto a él de Anaguarque; ofrecianle niños. Cobo. Loc. cit. En la lista de las huacas del Cuzco, que nos ha trasmitido Cobo, tomándola de Ondegardo, hay más de una repetición. 
zás los proyectiles empleados por Ayar Cachi, que al juzgar por sus efectos, debieron ser de considerable tamaño, las piedras llamadas galgas de Guanacauri, Cumpu-guanacauri (cum$p a=$ peñasco movedizo, galga que se emplean como arma defensiva en la guerra, arrojándolas contra los invasores, desde las montañas) que eran huaca del quinto ceque de Contisuyo (1). «La segunda guaca (del sexto ceque de Contisuyo) se decía Guamán. Es una piedra que estaba en Cayocache> (2).

*La segunda Guaca (del sétimo ceque) se llamaba Rocramuca. Era una piedra grande que estaba junto al templo del Sol» (3).

Al octavo ceque, pertenecían las piedras Quiacasamaro (4) (amaro $=$ serpiente).

Por huacas eran tenidas, diez piedras que estaban en el cerro Oumpi, (cumpi=galga, que se arroja desile un monte, por defensa (1).

1) La quinta se decia Cumpuguanacauri. Es un cerro derecho de Choco, encima del cual había diez piedras que tenian creido habia enviado alli el cerro de Guanacáuri. Cobo. Loc. cit.

(2) Cobo. Loc. cit.

(3). Cobo. Loc cit.

(4). La octava Quiacasamaro eran ciertas piedras que estaban en un cerro mas alla de Cayocache. Cobo. Loc. cit.

(1). La undécima. Cumpi, es un cerro grande que está camino de Cachona, sobre el cual había diez piedras tenidas por idolos, Cobo. Loc. cit. 
En Chaquira (chaquiriy $=$ dar un poco de sed) había igual número de piedras adoradas (1). Oznuro era una piedra a la cual rendían honores divinos (2).

Considerando los datos acumulados en las páginas anteriores, se deduce que, si algunas piedras eran adoradas en el Cuzco, por estar relacionadas con una divinidad antropomorfa, tal como la llamada Reyna-madre, El fantasma que amojona. Las galgas de Guanacauri, otras nos dan indicios de cultos, sobre los cuales tenemos pocas noticias, como el tribatado a la serpiente; no menos de siete piedras estaban consagradas a este Dios, bajo diversas adrocaciones, siendo las más notables, Serpiente colibrí, Serpiente azul. No era de menor importancia, la adoración del halcón y no faltan huellas del culto tributado al puma (3).

(1. La tercera (del noveno ceque) Chaquira, es un cerro que esta cerca del camino de Alca encima del cual habia diez piedras tenidas por idolos. Cobo. Loc. cit.

(2). La primera (del undecimo ceque) era une :iedra no rouy grande llazsda Oznuro oue sstaba en la Chacra do los Hualparocas. Cobo. Loc cit.

(3). En Tiahuanaco se repiten constantemente, en la decoración de las estatuas, vasos, y en la llamada puerta del Sol, tres figuras estilizadas, que todos están de acuerdo en llamar el condor, el puma y el pescado. No será el dicho pescado, una 
El motiro del culto de muchas rocas, nos es desconocido, por pertenecer el nombre de algunas, a lengnas perdidas, o de las que no tenemos rocabularios suficientes $y$ caso origen debe remontar a un período, en el que, los habitantes del Cuzco, estahan sujetos a razas distintas de la quichua y aymara. De otras piedras huacas, ignoramos su nombre $\mathrm{y}$ sólo sabemos el lagar en que se encontraban.

Queda, no obstante, más de la tercera parte de las piedras adoradas, de las que se puede creer que eran objetos de culto, por tenerlas por extraordinarias y como receptáculos de la fuerza mística, de la esencia huaca; de una creían era "el pilar del mundo", de otra que daba vigor al Sol. Hay nombres, que claramente demuestran, que la razón del culto, era la forma extraordinaria de la piedra

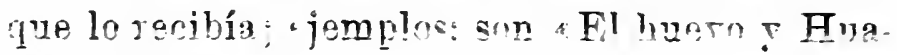
ca jorobadas.

\footnotetext{
Eex:ento! A! scrasi, en las huacas dal Cuzco, encontariazu:

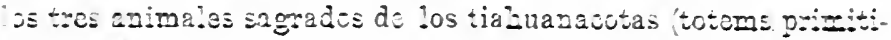
vos?: Sabido es, que el culto a Viracocha, tan valido entre jos incas, era propio de la civilización tiabuanacota, y asi como los e hijos del Sol continuaron la adoración de Viracocha Taripa. cả, (el ágila) bien han podido seguir venerando a los animales sagrados del viejo Imperio. Chle und Stübel. Die Ruinestactto von Tiahuapaco. Berlin 1802.
} 
Otro particnlar interés tiene el estudio de los nombres de las huacas veneradas en el Cuzco y es la demostración de que lo que fué capital del Impierio y centro de la expansión incaica, estavo un tiempo, bajo la dominación aymara, lo que comprueba la exactitud de las hipótesis, emitidas por el Dr. Max Uhle, al tratar del origen de los Incas, quien opina, que la monarquía de Tiahuantinsuyo, tavo principio en la disolución del señorío aymara (1).

El famoso visitador de idolatrías, el $\mathrm{Pa}$ dre Avila, encontró en San Damián de Hnarochirí, un ídolo llamado Macahuiza, que era una piedrecilla azul, que los indios guardaban, juntamente con otros ídolos, en nnos pe$\tilde{\mathbf{n}} \operatorname{ascos}$ de muy difícil acceso (2).

O tro ejemplar de este ídolo, lo conservaban en una casa en donde vivía una mnchacha paralítica, desposada con el ídolo, el cual esta-

(1) Chle. Los origenes de los Incas. Actas del XVII Congreso Internacional de Americanistas. Buenos Aires, 191:.

(2i En Sn Damian (de Huarochiri) quo es el pueblo prin. cipal, tenia yo noticia auia tres o quatro Idolos muy celebrados y seruidos, el uno llamado Llacçaybuancupa ......... el otro Macauiça......... Estauan estos Idolos en vnas breñas ca. si inacessibles y era......... una pedrezuela azul. Avila. Tratado de los Evangelios, Lima 1646, vol. I, folio 29 vuelta; de los sin pumerar. 
ba en un cestillo, juntamente con mantas $y$ camisetas diminutas (1). El nombre de esta divinidad, parece relacianarla con los dioses de la vegetación; maca =una raíz comestible, semejante a la papa; huijsa = vientre.

El ayllo Llampilla, que vivía a nna legua de Huarochirí, tenía nna huaca «que era vna piedra como de tres quartas de largo y se romataba en una coronita como la palma de la mano, y solo esta se descubría entre otras losas que estaban en el suelo, porque lo demás estaba cubierto debajo de tierra y en ella una concabidad grande cubierta con las dichas losas, por donde le echaban todo lo que se ofre-

(1). (En Sn Damian fui) a casa de un indio cassado que tenia una hijuela qne andaba con un bordon en cada mano porque estaba tullida, y era mocuela de hasta diez y ocho a fos de muy buena cara, auianme dicho estaba esta dedicada por mujer a fn Idolo y que este era de oro, halle alli a la mu. chacha padre y madre: y luego entendieron a lo que yra $y$ entro la rieja en su aposento, sin aguardarme la hablasse saco rna canastilla, y dixo: Señor en esta canastilla esta el Idolo que quieres pedir, no es de oro sino una piedra azul, que dizen que el Inga lo dio a mis majores $y$ se tomo el de oro. y lo cuso en la casa dsi Sol en el Cuzco. Estaba alli la piedra y unas mantitas y camiset:ilas tay chiquitas de cumbe que eran dedicadas al Ijolo y no exedian del tamazo de la palma..... (La piedra era) representativa de Macauiga, Idolo a quien estaba esta mucharha dedicada y ofrecida. Avila. Tratado de los Evangelios, Lima 1646, Vol. I, folios 30 vuelta, de los sin pumeras. 
cia a aquel ídolo». Esta huaca estaba en una de las casas que los indios tenían junto a sus chacras. "Alli cerquita auía otro, dentro de una bobeda apartada de las demás casas, el qual no sabían lo que era, mas de que todos decían ser vna cosa tremenda y espantable donde nadie se atreuía allegar. Mando el $\mathrm{Dr}$ (Avila) desvaratar la casa $y$ dentro se hallo vna piedra fuerte como vna cabeza de un niño sin figura ninguna la qual estaba toda untada de las cosas que le aúan sacrificado, y esta debía de ser el idolo o otra que se hallo junto a ella del mismo tamaño de poco peso, por estar hueca y dentro tenía algunos pedacillos, que anian caido de la misma piedra y meneandola, lo qual debia tener para con ellos algun gran misterio» (1).

En un cerro habían « siete piedras puestas en orden que significaban diferentes idolos».

En Santiago de Anchocaya, había *uu idolo llamado Xamuña el qual es adorado de todos los indios de esta comarca, por no se que fabula que cuentan alla de que les ayudo en cierta guerra, y despnes desapareciendose

1) Favián de Ayala. Carta al Arzobispo de los Reyes, de Santiago de Arichocaya, 12 de Abril de 1611, Apéndice. 
se conrirtio en un gran peñasco $y$ risco.... encima del qual, $y$ al derredor auian muchas rentanas, hechas de piedras en memoria de diferentes nombres que tenia Xamuña, porque dicen $q^{e}$ rnas reces parecia uno, otras reces muchos, $r$ en el lugar en que dicen se desaparecio, estaba hecha rna como bobeda de piedras entre dos peñascos grandes por donde estaran todo lo que en sus fiestas $y$ sacrificios le offrecian" (1).

El famoso dios Coniraya, aseguraban se había conrertido en ana piedra que se veía en Cmiloma $y$ su amada Choque-suso, en otra llamada Cocccha, la que estaba a la entrada de una acequia. Quizás era una haaca, perteneciente a otro grupo, cayo estudio haremos oportunamente (2).

Los Mochicas adoraban a una piedra, Aleg-

1) Fabián de Ayala. Loc. cit.

(2.) I assi quedo la dicha Choquesuso hecha piedra en Ia roca de la dicha acequia, la cual se llama Cocochalla.

I arrira desta acequia, en otra alta, la qual se llama Tmilompa está otra piødra en que dizen que se conrirtió Coniraya. Avila. Relación de idolatrias de Huarochiri. Colección de libros $\mathrm{g}$ docamentos referentes a la Historia de! Perú, Tol. ZI, Lima 1918. pg. 131. 
pong, que significa deidad en piedra (1) (mochica, aiplen = el hacedor; pong= piedra, cerro). Los indios de Huamachnco, «adorauan algunas piedras tan grandes como huevos, $y$ otras mayores de diversos colores. Las quales tenian puestas en sus templos é guacas que tenian por los altos y sierras de niere» (2).

En esta interesante región del Perú, cuyos ritos nos son bastante conocidos, «en cada pueblo había una huaca, la que era una gran piedra hincada... la cual llamaban guachecoal y a esta tenían por ojo del pueblo» (3). Semejantes a las guachecoal, eran las piedras llamadas Ohichic, Huanca o Chacra camayoc; $($ chich $i=$ germinar, brotar, hucuncu $=$ piedra, peñasco; Chccrca camayoc $=$ el señor, el amo del sembrío, el cuidador, el amo de la huerta), que ponían paradas en los sembríos,

(1) Adoran también..... . a una piedra quien asta oy. llaman Alecpong, que quiere decir deidad en piedra. Calancha Chronica Moralizada. Barcelona 1638, pg. 551, Tol. I.

(2) Cieza de León. Primera parte de la Chronica del Perí. Serilla 1553, fol. xcriil.

(3) Relación de la religión y ritos de los indios de Guamachuco, hecha por los primeros Agustinos que allí pasarou, para la conversión de los naturales. Colección de documentos inéditos, relatiros al Descubrimiento, Conquista $y$ Colonización de las posesiones Esparolas en América y Oceania. Tol. III, Madria 1865, pg. 54. 
"porque piensan que aquella chacra fue de aquella Huaca y que tiene a cargo su aumento y como a tal la reverencian y especialmente en el tiempo de stmenteras le ofrecen sus sacrificios» (1). El estudio de estas huacas, encontrará su lugar, al tratar de Mama pacha, pues estaban relacionadas con el culto de las deidades de la vegetación (2).

Volviendo a Huamachuco, encontramos a Jamguanca y Janoguanca (hanan = lo alto, huchka = piedra de gran tamaño) grandes peñas, que tenían un culto muy organizado (3).

* En una xalca y despoblada tierra estaba una piedra como una mano.... a este ídolo llamaban Casquilca (4), tenía una casa hecha

(1) Arriaga, Extirpación de la Idolatría. Lima 1621, fl. 16.

(2) También vzan en algunas partes poner en medio de las chacras uua piedra luenga para desde alli invocar la deida de la tierra y para que guarde la chacra. Ondegardo, Los errores y supersticiones de los Indios. Confesionarios para Curas de Indios. Lima 1585, folio 2.

(3) Otra se llamaba Jamguanca e la otra Jamoguanca, que eran unas peñas muy grandes, todas estas tenian criados unos para hacer chicha y otros para vestilla. Relación de la religión $y$ ritos de los indios de Guamachuco, hecha por los primeros religiosos Agustinos que allí pasaron, para la conversión de los naturales. Colección de Documentos inéditos, relatiros al Descubrimiento, Conquista y Colonización de las posesiones españolas, en América. Vol. III, Madrid, 1865, pg. 32.

(1) Kasa = hielo. K̈elkay = dibujar. 
de molle... I otra granie para las fiestas: había en esta casa muchas lanzas para guardia de la guaca, estaba esta piedra e ídolo muj embixado.... a esta guaca concurrían siete o ocho pneblos a pedir agua» (1).

Igual favor, además de otros, esperaban obtener de Llaiguen. "En una cuera que tenía diez y ocho brazas de hondo.... entrabase a ella por unos escalones bien hechos, $\boldsymbol{I}$ en el hueco de abajo estaban muchas lozas muy bien puestas, $y$ a un lado puesta una piedra, que era el idolo que llamaban Llaiguen a quien mochaban» (2).

Atahualpa, usando de aquella benigna justicia, tan laudada en los incas, por haber predicho el triunfo de Huáscar, el famoso dios Catequil, mandó arrojar su imagen de la peña donde estaba $y$ poner fuego a la roca.

Los pedazos de la estatua, fueron más tarde recogidos por los sacerdotes de Catequil y los depositaron en un teinplo, hecho en su honor (3).

«Después de entrados los cristianos en lir

(1) Op. cit., pg. 29.

(2) Op. cit., pg- 28.

(3) Op. cit., pgs. 25 y 26. 
tierra, una india andaba pensando eu las cosas de Oatequil, apareciole una piedra pequeña $y$ ella tomola $y$ llevola al gran hechicero $y$ dixo esta piedra halle y entonces el hechicero preguntole a la piedra iquien eres? y la piedra respondio yo soy Tantaguayanay (1) hijo de Catequil.... y dende allí comenzalon a honrar y asi hallaron otro que se llamaba Fatazoro, y pintaronlos ambos y asi iban los hechiceros hallando piedras que fuesen hermosas $y$ decian que eran hijos de Oatequil» (2).

Si el ejemplo anterior, nos muestra una piedra adorada, por ser hija de un dios de forma humana, claramente se advierte la tendencia que tenían los huamachucos de los últimos tiempos del imperio incásico, a la antropomorfisación de sus dioses, en el modo que tenían de adorarlos «y la manera que tenian general cuando querian hacer su mocha o adoracion, era que hacian una almohada muy labrada de muchos colores e labores... . y hacian un cestillo o canastillo de verguillas muy hlancas, y texianlo con lana y era por abajo

(1) Tantay = reunir, juntar; huajyay = llamar a gritos; $n a=$ donde, qué. Etimologia muy dudosa.

(2) Op. cit., pgs. 27 y 28. 
ancho $y$ en lo alto angosto ; tenia cuatro o cincinco palmos de alto.... y en lo angosto hacian una red que no saliese fuera sino que quedase dentro una concavidad para poner la guaca, $y$ a este cestillo restian como a persona» (1).

En San Luis de Paute, adoraban unas piedras restidas, en representación del Sol. Se asegura que este calto fue introducido por el Inca (2).

La lapidaria de los antiguos peruanos, ha sido estudiada por Tschudi en un artículo muy erudito (3). $Y$ si las piedras preciosas eran objeto de estima y algunas quizá conopas, solo en Manabí eran objeto de culto público. En Manta, la antigua Jocas, era ídolo principal, una gran esmeralda, cuyo favor imploraban los que estaban enfermos, viniendo a su santuario desde lugares remotos. Teníanla

(1) Op. cit., pg. 20.

(2) $\mathrm{Y}$ después de que rino el Inga, restian unas piedras que las hacian adorar diciendo que era el sol. - Fray Melchor Pereira. Descripción de San Luis de Paute. Relaciones geográficas de Indias, Vol. III, pg. 167, Madrid, 1897.

(3) Tschudi. Contribuciones a la Historia, Civilización y Lingüística del Perú antiguo. Tol. II, pg. 73 y sigs. Colección de libros y documentos referentes a la Historia del Perú. Tol. X, Lima, 1818. 
guardada $y$ solo la sacaban en ciertos días señalados, exponiéndola ante el público de los derotos que le ofrendaban esmeraldas pequeñas (1).

La esmeralda era apreciada por los Incas y en la costa ecuatoriana se encontraba on abundancia; los primeros conquistadores pudieron recoger rico botín de esta piedra pre-

(1) El Señor de Manta... tenia una piedra de esmeralda de mucha grandeza. La qual tuuieron y poseyeron sus antecesores por muy renerada y estimada. I algunos dias la ponian en publico $y$ la adorauan y reveronciauan como estuuiera en ella encerrada alguna deidad y como algun indio o india estuuiese malo despues de haber hecho sus sacrificios yuan a hazer oracion a la piedra a la qual afirman que hazian seruicio de otras piedras. - De muchas partes de la tierra adentro renian los qe. estauan enfermos al pueblo de Manta a hazer los sacrificios y a ofrecer sus dones. Cieza. Primera parte de la Chronica del Perú. Serilla, 1553, fol. Ixir.

Se turo por dios una rica esmeralda en la prorincia de Manta... la cual ponian en publico algunos dias.... y cuando algunos estaban malos, ibanse a encomendarse a la esmeralda, y llevaban otras piedras esmeraldas para le ofrecer. Las Casas. De las antiguas gentes del Perú. Ed. de Jimenez de la Espada. Madrid, 1892, pg. 51.

Turieron los del Perú entre otros dioses muy famosos una Esmeralda, la cual era grandísima $y$ de precio inestimable, esta no estaba puesta en publico, como los demas idolos mas tenianla guardada como reliquia y sacabanla en ciertos dias señalados. Román y Zamora. Repúblicas de Indias. Madrid, 1897, Vol. I, pg. 65. 
ciosa, que, por su ignorancia malbarataron (1). Minas de esmeraldas, sólo so han ballado en las altas regiones de Cundinamarca, (Colombia central), pero la nnánime tradición de los primeros tiempos de la conquista, señala la existencia de yacimientos de esmeraldas en Manabí (2). Los aborígenes de la costa ecuatoriana, hacían cuentas de collares de esmeraldas, dando a la piedra forma esférica $y$ perforándola.

Todos los pueblos cirilizados de América, consideraban la esmeralda como la piedra más rara y preciosa. Los Natchez fabricaban con ella, flechas simbólicas. En México, las esmeraldas eran tenidas como el más apreciado tributo que se podía rendir al dios Pinotetel y servían de insignia a los jefes de Tescuco (3).

(1) Estete. El Descubrimiento y la Conquista del Perú. Boletín de la Sociedad Ecuatoriana de Estudios Históricos Americanos. Vol. I, Quito, 1918, pg. 516.

(2) $\mathrm{Y}$ cierto mucho ha sido el numero de esmeraldas que se han visto y hallado en esta comarca de Puerto Viejo, y son las mejores de todas las Indias; porque aunque en el Tinevo Reino de Granada hay mas, no son tales ni con mucho se ignalan en ralor las mejores de alla a las comunes de aca. Cieza. Op. cit., fol. lxir.

(3). Denis Ferdinand). Les emeraudes et leur culte en Amerique.-Rerue Orientale et Americaine, Vol. I, Paris 1559, pgs. $172-176$. 
El conocido mitólogo, Robertson Smith, a propósito del culto de las piedras, hace las siguientes reflexioves.

«El culto a piedras sagradas, es a menudo calificado como un tipo religioso, inferior a aquel en que se adoran imágenes. Llámaselo fetichismo, término vago que no evoca idea alguna precisa, pero que siendo muy popular, se interpreta por algo salvaje y rudimentario. No bay lugar a duda, que bajo el punto de vista artístico, la adoración a piedras sin desbastar, es algo muy pobre, mas considerado religiosamente, la evidencia de la inferioridad es dudosa. La hostia, en la misa, es tan inferior artísticamente a la Venus de Milo, como es el massêba semítico, mas nadie se atreverá a afirmar, que el cristianismo medioeval, ralga menos que al culto de Afrodita. Lo que al parecer se expresa, al llamar fetiches a las piedras sagradas, es que datan de una ópoca en que se les consideraba como la encarnación natural del dios y su forma propia y nó como el tabernáculo en que residía la divinidad, para recibir el homenaje de sus devotos.... El hombre no comenzó por adorar los emblemas de los poderes dirinos, sino por tributar su culto al Dios mismo. Si se concebía 
al Dios, como presente, el ejercicio natural de las facultades artísticas, le hacía añadir algo en la piedra y si el Dios era concebido bajo forma humana, se trabajaba en la piedra una figura antropomorfa, o un bosqueju de las facciones más importantes.... Parece probable, que escoger un pilar o carín, como el ídolo primitivo, no obedecía a otras consideraciones que la facilidad ritual. La piedra o montón de piedras, era una señal cómoda para indicar el lugar adecuado para el sacrificio 5 al mismo tiempo, si la deidad consentía en estar presente en el lugar, facilitaba el rito de la ofrenda de la sangre sacrificada" (1).

Nada en efecto es más difícil, que precisar el grado de evolución religiosa a que pertenece el culto de una piedra. Los puros adoradores de Jevé, así como los israelitas prevaricadores, levantaban pilares de piedra, sin forma humana y a reces desprovistos de todo trabajo, como emblemas divinos. Estos pilares eran conocidos con el nombre de massebah (2). Mas usanza común con los otros pueblos se-

(1) Robertson Smith. Lectures of the Religion of the Semites. London 1914, pgs. $209-211$.

(2) Vigouroux. Dictionaire de la Bible. Vol. III, París 1899, pg. 820 . 


\section{Religión del Imperio de los Inoas}

mitas, vino pronto a convertirse en práctica idolátrica, así la Biblia cuenta, que el culto a los messebah atrajo el castigo de Dios sobre su pueblo y castigó la prevaricación con la toma y saco de Jerusalén, por los ejércitos de Besac, rey de Egipto; Ozee II y Jonás ordenaron la destrucción de las piedras consagra. das, cuya erección estaba prohibida en el Deuteronomio (1).

La dificultad, que acabamos de manifestar, no obsta para que pueda trazarse teóricamente la evolución del culto de la piedra, $y$ señalar ejemplos que correspondan a cada grado evolutivo.

La concepción primera de la divinidad, como una fuerza superior inmanente en algunos seres de la naturaleza y cuyo signo es la apariencia extraordinaria del ser que la posee (2), corresponde, a no dudarlo, con la piedra divina en sí. Mas la piedra sigue siendo objeto de veneración, cuando ya no es dios,

(1) Libro primero de los Reyes, Cap. XIV, rer. 24. - I de los Reyes, Cap. XVIII, rer. 4. - II de los Reyes, Cap. XXII, ver. 14 - Deuteronomio. Cap. XVI, ver. 22 - Waltonus. Biblia Polyglote, Londres 1657, Vol. II. pgs. 478, 592, 614, Vol. I, pg. 788.

(2) Vide supra, pg. 70. 
sino solo el altar de la deidad, el lngar adecuado para su culto, y aún su erección como simulacro divino, puede corresponder a concepciones teosóficas más elevadas que el puro antropomorfismo, aquellas en que el Dios es tenido por algo espiritual, superior al hombre y distinto de él; entónces la piedra no es sino el centro del culto, el lugar en cuyo rededor se congregan los fieles por obra de las necesidades sociales del hombre, que no puede en sus arranques supraterrenos, prescindir del templo y de la oración, en comunidad.

Hemos señalado una de las vías que puede seguir la evolución de la piedra dios; réstanos esbozar el otro camino.

Concebida la piedra como receptáculo de mana, en aquellos pueblos dotados de cualidades artísticas e imaginación fecunda, la piedra mana adquirirá individualidad propia, recibirá poco a poco caracteres humanos $\mathrm{y}$ protegida por su carácter sagrado contra el cincel del artista, será el cuerpo petrificado del dios, cuya metamórfosis se cuenta.

Lo expuesto se rerá más claramente, en algunos ejemplos de adoración a las piedras, cuyo estudio, además de comprobar la doctrina enunciada, nos facilitará el apreciar el signi- 
ficado de la adoración de las piedras, entre los antiguos peruanos.

Los Ohibchas, cuyo sistema religioso recuerda mucho el de les súbditos de los Incas, adoraban a ciertos rocas (1).

Los Patagones tributaban culto a grandes piedras aisladas (2).

Los Natchez guardaban en un templo una piedra cónica, cubierta de pieles de renado (3).

El gran oráculo de los Mandan, era una piedra larga y porosa. Cada primavera, $\mathbf{y}$ en ocasiones en el rerano, una diputación risitaba solemnemente la roca, para consultarla $y$ fumaban invitándola. Unas marcas, que con blanco hacía uno de los de la diputación, mientras los otros dormían, eran tenidas por la respuesta (4).

Los Cheroquíes reverenciaban algunos objetos inanimados, siendo el principal la piedra,

(1) Reville. Les Religions du Mexique, de l'Amerique Centrale et du Perou. París. 1855, pg. 267.

(2) Reville. Les religions des nou civilisés. París, 1853, Tol. I, pg. 394.

(3) Iafitau. Moeurs des Saurages Ameriquaines. Paris, MDCCXXIT., Fol. I, pg. 148.

(4) Frazer. Pausanias's description of Greece. London, 1888, Tol. IT, Fg. 104. 
a la cual el brujo ruega, cuando quiere encontrar un objeto perdido (1).

En Samoa se adoraba a ciertas piedras que suponían habitadas por espíritus. En uno de los pocos templos que había en la isla, so guardaban tres piedras desproristas de todo trabajo; la una era la inamorible, la segunda la endurecedora del reino, la tercera la piedra tija (2).

En otro templo había dos cantos rodados, que vadie extraño al culto, podía rer; eran dioses buenos, que daban a sus derotos rames $\Sigma$ enriaban a sus redes peces (3).

En un pneblo de la isla, se guardaba esmeradamente una piedra, tenida por el dios de la lluria (4).

En la isla Francis u Onaota, hacían sacrificios 5 oraban a una piedra parada (5).

En Aneitium de las Nueras Hébridas,

1) Mooney. The Sacred Formulas of the Cherokes. ith Anuual Roport of de Bureau of Ethnology 1385 - S6. Tasbington, $1892, \mathrm{Fg} .341$.

(2) Brown (G.) Melanesians and Polinesinns. London, $1910, \mathrm{pg} .225$.

Turner. Samoa. London. 1SS4. pg. 46.

(3) Tumer. Samos. Loudon 13st, pg, 45.

(4) Id. id.

(s) Id., id.. pg. 288. 
creían que ciertos cantos, eran los representantes de una deidad, $\boldsymbol{y}$ cuando encuentran uno de éstos, piensan haber dado con un dios. Si el canto se asemeja a un pez, será reverenciado como el dios de los pescadores; si se parece a un yam, como el de este comestible; si a la fruta del pan, rendiránle el homenaje debido a la deidad del árbol del pan (1).

En las Nuevas Hébridas septentrionales, las piedras son el medio de entrar en comunicación con los espíritus, ofreciendo sobre ellas sacrificios.

En Whitsuntide Araga, hay piedras conectadas con los espíritus, que se ballan en lugares sagrados, conocidos tan solo por los poseedores o descubridores del receptáculo mana, quienes sirren de intermedio entre los devotos $y$ la piedra, haciendo ellos los sacrificios que se les encomienda (2).

Las piedras tienen lugar conspicuo en la religión de las islas Salomón (3).

En Santa Cruz, hay piedras relacionadas con espíritus, a las que se ofrecen sacrificios (4).

(1) Id., id., Fg. 327 .

(2) Coddrington. The Melanesius. Oxford, 1891, pg. 143.

(3) Id., id., pg. 178.

(4) Id., id., pg. 181 . 
Relacionándose en las Nuevas Hébridas, así como en las islas Banks, la religión con espíritus que nunca se conciben como autropomorfos $\mathbf{y}$ caracterizados por su naturaleza mana, el que encuentra una piedra en la que advierte algo anormal, cree tener mana y le rinde culto $\mathrm{y}$ si sus negocios prosperan $\mathrm{y}$ sus cosechas son abundantes, el culto de la piedra se propaga $I$ sus recinos le encomiendan sacrificios, en honor de la flamante deidad, de cuyo culto conviértese en ministro.

En Losalar, en la isla Saddle, hay cerca de la orilla, un círculo natural de piedras, que es reverenciado desde tiempo inmemorial $y$ honrado con ofrendas.

Si la semejanza con un objeto deseado, es la que determina en la mayor parte de los casos, el culto de las piedras, no faltan algunas que son tenidas por nefastas, por haber en su vecindad sucedido algún caso desastroso.

Las grandes piedras tienen lugar preeminente entre los objetos sagrados melanesios.

En las islas Banks, las hay muy notables, por su largo, que son llamadas tamate gamgan, esto es, kespíritu que come», que creen son muy poderosas y malérolas, siendo bastante para matar a un hombre el que la sombra de Relígión del Impsrio de los Inoas 
éste toque la piedra. Colócanlas como guarda de las casas y si alguno va enriado por el dueño de una morada, que tiene tan buena guardia, debe anunciar el nombre de quien le envía, para que la piedra no le dañe. Además de estas piedras, que son inamoribles, los melanesios tienen otras muchas que son rerdaderos amuletos $z$ que sirren para obtener la fertilidad de los sembríos, o buena ventura.

Las ofrendas que hacen los melanesios a las piedras, es ungirlas con agua de coco, o untarlas tierra roja; esto último si se hace con una piedra parada, basta para disipar los nublados $y$ hacer brillar el sol (1).

En Madagascar, a muchas piedras, ungen con aceite y grasa, las mujeres deseosas de tener hijos (2) y es, sin duda, una costumbre fundada en magia imitativa, la de poner una piedra en el cimiento de una casa, para asegnrar la prosperidad de la familia. (3).

En la costa de Nigeria del Sur, el culto

[1] Coddrington. The Melanesians. Oxford, 189, pge. 181-185.

(2) Frazer. Pausanias's description of Greece. London 1888, Vol. V, pg. 355.

3) Abinal. L'Astrologie Malgache. Missions Catholiques, Fol. XI, Lyon 1879, pg. 482. 
a las rocas y piedras está poco desarrollado, por la carencia de éstas, no así en la región montañosa, en donde su culto es muy importante.

No obstante la carencia de piedras on Boni, los Ibani tienen por dios, una que deben haber traído de muy lejos.

En medio de un pequeño bosque sagrado, los Ibibios tienen una piedra, llamada el rey del bosque, a la cual atribuyen mucho poder.

En Uwet se venera un aereolito.

Los Ibos, del clan N'doke, que moran en Akwete, el dios principal, creen, reside en unä piedra que está en medio de un riachuelo, en el que se proveen de agua (1).

Los Bogos creen dar estabilidad a un juramento, haciéndolo sobre una piedra (2).

Los Todas tienen a muchas piedras como sagradas $y$ poseedoras de cierto grado de santidad, y que ocupan lugar en el ceremonial religioso. Todas tienen nombres, ya generales, ya individuales, pero dos piedras del mismo nombre, pueden tener atributos enteramente diferentes.

(1) Leonard. (A. J.) The Lower Niger and its Tribes. London 1906, pgs. 306 y 307.

(2) Frazer. The Golden Bough, Vol. I, pg. 161. 
En el ti, la más sagrada institución de la lechería, que es el centro de la vida Toda, hay piedras que señalan el lugar en donde se debe levantar $\mathrm{y}$ asentar el vaso, durante el rito de la emigración. Más importantes son en la lechería, las piedras llamadas neurwilnkars, que son ungidas con aceite.

Estas gentes hacen sacrificios a ciertas piedras, como a las funerales, en las que matan búfalos (1).

Los Kalís que moran en Abui, juran por un meteorito (2).

En todo pueblo Marring, hay un círculo de piedra $y$ en su interior unas pocas, que inrocan en sus juramentos (3).

En las aldeas Tangkhul, se encuentran montones de piedras, tenidos por muy sagrados y que los manipures llaman lei-pham, la morada de $l e i$, entidad potente y misteriosa, no siempre antropomorfa. Al regreso de sus expediciones guerreras, los Tangkhules ponían las cabezas de las víctimas en estos moutones, durante un período de cinco días, en el cual

(1) Fivers. The Todas. London 1906, pgs. 438-441.

(2) Hodson. The Naga tribes of Manipur, London 1911, pg. 111.

(3) id, id, pg. 112, 
los guerreros eran genna, esto es, que se eneontraban bajo el peso de un tabú.

Hodson, dice, que las piedras de forma extraordinaria, se las mostraban como lei-pham. Oaminando por las montañas, se encuentran montoncitos de arroz, hojas, flores y tabaco, ofrendas votivas al lei, que tiene allí su morada y a las que contribuyen peregrinos $\mathrm{Na}$ gas, Kukis y Meithers, así como comerciantes de Bengala (1).

En el país ocupado por los Nagas, es importantísimo el culto de la piedra, ya en la forma de monolitos, carines, piedras planas, soportadas por otras pequeñas. Los monolitos, o están aislados, o dispuestos en avenidas, círcalos u óvalos.

En las afueras de Marán, ciudad que fue próspera y populosa, hay una avenida de monolitos, casi todos en pie, y en la población, círculos y óvalos. Uno de los monolitos de la ringlera, que forma la calle, está asociado con la suerte de los cazadores y antes de salir toda expedición de caza, ra al lugar donde está la piedra y los que la componen, tratan de dar una pedrada en la punta del monolito,

(1) Hodson. Op. cit., pg. 126. 
seguros de que si tal hacen, la cacería tendrá mucho éxito.

En Uilong hay una interesante coleocion de piedras, dispuestas en un óvalo y en un círculo; dentro de éste, los solteros bailan $y$ descansan durante el genna anual, en honor de los muertos.

No todas las piedras sagradas datan de tiempos remotos, pues los Nagas las erigen aún hoy, lo que da lugar a varias ceremonias y tabús, entre los que merece notarse la castidad, que está obligado a guardar, durante un año, el que las erige, quien por este tiempo debe vivir alejado de los suyos. En Nao, dicon, que a aquel que erige una piedra, su padre ayuda, lo que parece indicar están relacionadas con el culto de los antepasados.

Carines cónicos de piedra, se encuentran en Tanghhule y Zudirengs.

Trilitos formados por dos piedras pequeñas y una grande, a modo de mesa, solo bay en Merán.

Oerca de Hudung, hay una piedra que conmemora, según dicen, la conquista de Tangkul, por Ohing Thangkomba, a la cual dan culto cada año. En Maikel se ve una piedra, en el lugar por el que dicen salieron sus ante- 
cesores del interior de la tierra. Todas estas piedras, creen, son la morada de espíritus (1).

En Berar se rinde culto a aquellas piedras que tienen algo notable por su forma, tamaño o posición; la adoración a piedras $y$ palos se reproduce constantemente en diferentes formas (2).

Entre las tribus del Hindoo Koosh, la mayor parte de los objetos de culto, son grandes piedras; en cada pueblo se les llama de diferente manera. Juran por estas divinidades, a las que hacen sacrificios (3).

Así es difícil exista un solo pueblo en la India septentrional, que no tenga una piedra divina, a las que, a menudo, honran pintándolas con ocre rojo; éstas a veces no tienen nombre propio y reciben la designación genérica de Gramaderãta, u otra semejante (4).

En los ritos brahmánicos, que se observan con ocasión de un matrimonio, una piedra desempeña papel muy importante. Coloca el

(1) Hodson. The Naga tribes of Manipur. London 1911, pgs. $186-190$.

(2) Lyall. Asiatic Studies, London 1899, pgs. $9-13$

(3) Biddulph. Tribes of the Hindoo. Calcuta. 1880, pg. 114.

(4) Crooke. Popular religion and Folk-lore of Northern India. Westminster 1896, Vol. II., pgs. 163 y 165. 
Akarya una piedra hacia el norte, entónces el novio se levanta cuando se repiten las palabras: « $\nabla \theta n$ acá dichoso y pisa con la punta de su pie derecho, en la piedra y el oficiante dice: "Ven, pisa en la piedra, como la piedra sed firme, pisa a tus enemigos, domina a tus enemigos » (1).

Según otras disposiciones rituales, después de las rueltas al rededor del fuego y del agua, el desposado pisa sobre la piedra, repitiendo la invocación ya transcrita (2).

Igual rito se observa en la iniciación de los jóvenes brabmanes (3).

No cabe duda que, en el rito brahmánico, la piedra es un elemento de magia imitativa, la solidez del pacto se quiere sea como

(1). Sãnkâyana. Grihya. Sûtra I adhyâya. 13 Khanda. The Grihya Sutras, Rules of Vedic Domestic Ceremonies. Translated by Oldemberg. Part. I, Oxford 1886. The Sacred Books of the East. Vol. XXIX.

12) Asralayana. Grihya I Adhyayâ, 7 kandica. Loc. cit, pg. 168.

Pâraskara Grihya. Sutra I, 7 kanda, kandikâ 1. Loc. cit, pg. 282.

Grihya Sutra de Hiranyakesin Prasna I, 6 Patala 19 Sección No. 8. The Grihya Sutras, translated by Oldemberg. Part II, Oxford 1892. The Sacred Books of the East, Vol. XXX.pg. 188.

(3) Grihya Sutra de Hiranyakesin. Prasma I, Patala I, 4 Sección, No. 1., Loc., cit. pg. 146.

Comp. Hoplins (E. W.). The Religions of India. London 1896. 
la de la piedra, la estabilidad del conrenio, al igual de la inmorilidad de ésta, la firmeza de la unión tan dura como la roca; mas si tenemos en cuenta el carácter divino de las piedras, en muchos pueblos de la India, comprenderemos que el rito brahmánico, estaba basado en un recuerdo de las piedras dioses, de los aborígenes de esa península asiática.

Los árabes, antiguamente, tenían pilares de piedra, llamados msob, que ungían con la sangre de las víctimas; eran altares, si bien a reces se confundía el ídolo con el ara (1).

En los antiguos santuarios Cananeos, había una piedra y un poste sagrado, el asherah y el massebah; en el de Gezer, parece que los masseboh eran dioses de la fertilidad (2).

Cree Sérillot muy probable, que muchos siglos antes de nuestra era, los pueblos de la Galia creyeron que determinadas piedras, por su tamaño o forma, eran la morada $d \theta$ poderes sobrenaturales, que les comunicaban cierto poder: esta creencia subsiste en algunos casos, en que la tradición señala tal o cual pie-

(1) Smith. Lectures on the Religion of the Semites. London 1914, pg. 205.

(2) Frazer The Golden Bough. A Study of Magic and Religion. London 1914, pgs. 107-108. 
dra, como la morada de una hada, u otro personaje mitológico, o en los que el vulgo acade a determinadas piedras, en ciertas ocasiones, implorando su auxilio (1).

Los Concilios de Arles (452), de Tours (507), de Nantes (658), condenaron el culto de las piedras y en España, los que se reunieron en Toledo, en 681 y 682 , fulminaron recias censuras contra sus adoradores (2).

La forma más común del culto a las piedras, que aún subsiste en Francia, es la práctica conocida con el nombre de «la glissade», cuyos fines son de amor $y$ fecundidad.

En el departamento de Ille et Vilaine, hay unas rocas dichas Roches Ecriantes, a las que acuden muchachas casaderas y por las que se dejan resbalar.

En Ploiier (Côtes du Nord) hay una piedra de este género, a la que van las muchachas por saber si se casarán en el año, para lo cual se alzan los vestidos y se resbalan por

(1) Sévillot (P) The Worship of Stones in France. American Anthropologist. N. S. Vol. IV, New York 1902, pg. 78.

(2) Reinach (S). Les monuments de pierre brute dans les langage et les croyences populaires. Cultes, Mythes et Religions. Vol. III, Paris 1913, pg. 400. 
la piedra, siendo señal afirmativa, no rasparse la piel en la bajada (1).

En la Oreuse, las muchachas que tienen igual deseo, se arrojan del dolmen, dicho $\ll \theta 1$ bosque de Urbe», o se dejan resbalar por una roca inclinada, o bien se frotan contra una «allée couverte».

En el Sena Inferior, se resbalan por la estrecha abertura del Dolmen de Ymara, para curarse de las enfermedades a los riñones (2).

Cerca de Poncin, a una legua de San Albán, hay una roca, en la que resbalan las mujeres en cinta, para tener fácil alumbramiento (3).

De las piedras, acerca de las cuales corren entre los paisanos franceses ideas supersticiosas, la mayor parte son dolmenes o menhires, los que generalmente inspiran terror a los campesinos, que junto a ellos pasan; tal acontece con el menhir de la Dama Blanca, en Ille et Vilaine, ante el cual, los campesinos se santiguan, pará conjurar los males que podría causarles.

En Ploliares (Oôte du Nord) un dolmen

(1) Sévillot. Op. cit,, pg. 79.

(2) Reinach. Op. cit., pgs. 405, 408.

3) Sévillot. Op. cit., pg. 82. 
es la capilla de los siete santos; en España hay dolmenes, que ahora son criptas de iglesias, o capillas. Cuentan en los Pirineos que, un campesino que quizo poner una cruz sobre un menhir, fué muerto por el genio del lugar (1).

Coquebert Monbert, en 1820, encontró en un dolmen del Loira inferior, llamado * pie. dra de las hadas", montoncitos de lana rosa, puestos por las muchachas deseosas de casarse; igual costumbre se obserraba en el menhir Long-B̈̈el (Sena inferior) y en algunos lugares del departamento del Sena y Marne; a la piedra de San Martín (Indre et Loire), ofrecen centaros, frutas, queso, etc. Estas ofrendas tienen lugar en otros sitios, con diversos fines, tales como recobrar la salud, tener éxito en el amor (2).

En el valle de Larboust, en los Pirineos, los paisanos van en secreto a rezar junto a las piedras sagradas, bésanlas $y$ apoyan la oreja contra ellas, esperando oír su voz; en Finisterra, el menhir de Plouarzel, tiene a la altura de un metro, unas protuberancias de 30

(1) Reinach, Op. cit., pgs. $399-403$.

(2) Reinach. Op. cit., pg. 404.

Sévillot. Op. cit., pgs. $102-104$. 
centímetros de diámetro, poco más o menos, semejantes a un seno; los recién casados ran al menbir y después de haberso parcialmente desnudado, la mujer de un lado $y$ el hombre del otro, se frotan el vientre contra las prominencias, esperando el marido tener hijos ralones y la mujer mandar en la casa (1). Esta misma costumbre había en $\operatorname{Dax}(2)$.

En Carnac, muchachas casi desnudas, se frotan el vientre contra un menhir, para pronto conseguir un marido; igual costumbre se observa en el departamento de Eure et Loire y en Roce Marie, cerca de Snt. Aubin da Cormier (Ille et Villaine) (3). Fn rarios lugares se frotan contra un menhir, las mujeres estériles (4).

Es común a muchas piedras de Bretaña, la facultad de devolver la salud al que en ellas se frota; en otros lugares es preciso subir a la piedra, para obtener los beneficios de su poder sobreuatural; así en Colombiers, en donde el que quiere casarse antes de un año,

1) Sevillot. Op. cit., pg. 405.

(2) Sévillot. Op. cit., pg. 83.

(3) Sevillot. Op. cit., pg. 82.

(4) Reinach. Op, cit., pg, 405. 
coloca en la cúspide de la piedra, una moneda y baja luego de un salto.

Cerca de Fougarais, hay una piedra, llamada «la silla del diablo», en la cual, sentándose en cierta época del año, se obtiene ser correspondido en amor (1).

Hay piedras que dan salud a los que suben a ellas, o las risitan; un dolmen de Finisterra cura los reumatismos, otro a los calenturientos; en Ablancourt (Somme) sientan a los niños enfermos, en un banco de piedra, colocado en la capilla de San Jorge; en el Oise creen que sanan, dando vueltas a la piedra de Sn. Vaast.

En un hueco natural, que hay en el pedrón del pueblo de Kerangalet, en Gouesnon (Finisterra), introducen el miembro enfermo, esperando curarlo; al menhir, dicho la "piedra agujereada ", en la Yonne, lleraban a los animales enfermos $y$ para que se curasen, depositaban una moneda en el hueco (2).

A reces, al rededor de una piedra, celebraban danzas, así en Orosse, hasta fines del siglo ZVIII, el 15 de Agosto, las mujeres del

(1) Sévillot. Op. cit., pgs. 84 y 85 .

(2) Reinach, Op. cit., pgø. 405, 400 \& 407. 
pueblo, teniéndose por las manos, bailaban al rededor de la Pierre Longue (1).

Una piedra movible de los Pirineos, se asegura produce aguaceros, al ser puesta en movimiento (2).

Es frecuente llamar a menhires, piedras del juramento, lo que recuerda la costumbre india, ya mencionada; así en el Oise van todavía a firmar los contratos de matrimonio, en una esquina de la Pierre Lartierre y en Ancelle (Altos Alpes), los recién casados pasan los brazos por el hueco de cierta piedra (3).

En la isla Roma, vecina a la costa de Escocia, hay una capilla dedicada a Sn. Román y en ella un muro de piedra, cuya limpieza cuidan mucho. En el altar hay una plancha de madera con varios huecos, en los que están puestos guijarros, a los cuales los isleños atribuyen grandes virtudes, entre otras, la de dar fácil parto (4).

(1) Sévillot. Op. cit., pg. 91.

(2) Reinach. Op. cit., pg. 409.

(3) Reinach. Op. cit., pgs. 405 y 409.

(4) Martin. A Description of the Western island of Scotland. Pinkerton, Voyages and Travele, Vol. III, pg. 681, London 1811. 
En Escocia, algnnas reces, los jurados se sentaban en piedras consagradas para este uso; igual cosa acontecía en Atenas (1).

En Laconia se conserraba una piedra rústica,en la cual, según la leșenda, el matricida Orestes, se mejoró de su locura apenas se sentó, habiendo ocurrido anteriormente otro tanto a Zeus, que se curó de su amor a Hera, al sentarse en cierta roca, en la isla Leucadia (2).

Los Ingouch, tribu del Caúcaso, adoran ciertas piedras $\Sigma$ les ofrecen costosos sacrifi$\operatorname{cios}(3)$.

En gran parte, de los ejemplos citados, se adrierte que la piedra es santa 5 está dotada de fuerza mágica mararillosa; en algnnos, como en los de Melanesia, sábese bien que este poder es la entidad misteriosa mana; en otros, como en las piedras dirinas de los Nagas, la fnerza mágica ha recibido sa una forma más diferenciada, es el lei, entidad potente 5 misteriosa, que no siempre tiene forma antropomorfa, sa que el objeto renerado

(1) Frazer. The golden Bough. A Study Magic and Religion. Iondon 1913, Tol. I., pg. 160.

(2) Id. id., pg. 161.

3. Frazer. Pausanias's description of Greece. London 1888, Vol, IV, pg. 160 . 
no es el receptáculo adecuado del poder supra sensible, sino la residencia del espíritu poderoso, no es el imán, sino tan solamente el hierro imantado, que puede perder su fuerza, en cuanto desaparezca la corriente que la causa.

De la piedra, residencia del lei, hay corta distancia en la evolución religiosa, a la piedra altar, lugar adecuado para ofrendar al Dios, y de las etapas de esta evolución, no faltan ejemplos, en los casos citados en las páginas antecedentes.

Réstanos ahora comprobar con hechos, la otra vía del desarrollo de la piedra Dios, que señalamos ya, aquella en que termina el culto a una roca, por originar un mito metamórfico y un culto netamente antropomorfisado.

Las dos vías de evolución, tienen igual valor trascendental y si las formas correspondientes a la primera, parecen más frecuentes en pueblos primitivos, deja ésta libre campo para un progreso religioso, continuamente ascendente, no así la segunda forma evolutiva que, conduce de un modo ineludible, al estancamiento del desarrollo teosófico.

En Australia, los Aruntas llaman Ohuringa a piedras sagradas que llevaban los antecesores y que están relacionadas íntimamente Religion del Imperio de los ince. 
con el espíritu de éstos y por consiguiente con el de sus sucesores; los churingas no pue. den ser vistos por las mujeres, ni los no iniciados. El lugar en el cual depositó el $A l$ chiringa, o antecesor mítico, el churinga está señalado por algún objeto natural, tal como una roca, un árbol. En este sitio creen que reside, especialmente, el espíritu del Alchiringa y se llama Nauja (1).

En la ceremonia de Intichiuma, de la Ungianba, o del totem de la flor Hakea, con la que hacen una bebida muy estimada, nno de los celebrantes, so abre una vena y deja caer la sangre sobre una piedra, que representa la flor; en el Intichuima, del totem Yarumpo, se practican ceremonias sobre una piedra, que representa el Alchiringa Erkiaka y la frotan con guijarros (2).

Los Kaitish tienen una piedra llamada de los niños, a la cual acuden cuando desean tener hijos, llevando su churinga y frotándolo contra la piedra (3).

(1) Spencer and Gillen. The Natives tribes of Central Aus. tralia. London 1889, pgs. 129, 124, 128, 131.

(2) Spencer and Gillen. Op. cit., pgs. 187 y 188.

(3) Spencer and Gillen. The Northern Tribes of Central Australia. London 1904, pg. 271. 
Los Oanaques labran piedras en la forma del objeto que desean y conviértenlas en fetiches (1).

En las Nuevas Hébridas, había igual costumbre (2).

Tonge y Toafa, eran los nombres de dos rocas planas, que estaban en una plataforma, formada por un hacinamiento de piedras, a las que en Samoa veneraban, por tenerlas por padres de Saato, dios de la lluvia (3).

En Sarai, los dioses de cierto pescado, fueron convertidos en piedras, por el héroe mítico, Upulu (4).

En el camino que conducía a las plantaciones en Samoa, había una piedra, que decían ser un cobarde petrificado, habiendo apostado con su hermano, a cuál era el más valiente, volvió la espalda y según lo que habían convenido, se transformó en piedra. En la misma isla, en el límite entre dos pueblos, se veían dos piedras, en que se convirtieron dos mozos que, batiéndose, se mataron (5).

(1) Glaumont. Usages, Moeurs et Coutumes des Neo Caledoniens. Revue d'Ethnographie. Paris 1889, Vol. VII, pgs. 114-115.

(2) Frazer. Pausanias's description of Greece. London 1888, Vol. IV, pg. 154.

(3) Turner. Samoa. London 1884, pg. 25.

(4) Id., id., pg. 31.

(b) Id., id, pg甲, 46 y 46. 
Para los aborígenes de la isla Fakabfo, el dios principal se llama Tin Tokelan, el Rey Tokelan, que creían estaba encarnado en una piedra, que tenían cubierta con finas esteras y que sólo el jefe podía rer. En la isla Nuku-laelac, del archipiélago Mitchell, los dioses Fonolape y Moloti, eran dos piedras, así como Foelangi, adorado en la isla Hudson (1).

En la isla San Agustín, era reverenciado un bloc coralino (2).

En la isla Nikiman, del grupo Gilbert, habían dioses $\boldsymbol{y}$ diosas, que eran piedras; a las primeras tenían paradas, a las segundas acostadas, pues siendo señoras, sería crueldad tenerlas en pie largo tiempo (3).

La residencia del Ogaba, on Ogbanik, es una cueva, en cuyo interior se encuentra una piedra, que es el dios castigador de los ladrones (4).

Olirine, adorada en Omitcha, la diosa madre de todos, la nutridora de los muchachos

(1) Turner. Op. cit., pgs. 268, 280 y 289.

(2) Id., id., pg. 291.

(3) Id., id., pg. 296.

(4) Leonard. The lower Niger and its Tribes. London 1906, pg. 308. 
y protectora de su pueblo, es unas rocas que están en el bajo Niger (1).

Según las tradiciones de los Yorubas, los creadores del mundo, Jemuhu y Orishala, se volvieron piedras, las que están en Ife (2).

En un bosque sagrado, cercano a esta población, hay unas piedras que son un jefe (dui), su mujer e hijo, que por evitar una guerra, se retiraron al bosque y se petrificaron al morir. Estas piedras estaban on un curioso recinto sagrado; Morine, madre de Alashe, petrificóse también y es adorada; igual aconteció con el hijo, que cuando la madre lo iba a sacrificar, por salvar a la ciudad de Ife, amenazada por la ira de Dios, se volvió piedra, juntamente con todos sus bienes. Fuera de la población, hay un pilar redondo, de once pies de alto, junto al cual se veía otro pilar roto, en el que habían clavos, un círculo y una hacha; eran el bastón de Oranyan (3).

Los Bagandas, junto al templo del dios Nkulu, en Bewendo, tienen numerosas piedras blancas, que dicen ser sus mensajeros (4).

(1) Leonard. Op. cit., pg. 308.

(2) Dennett. Nigerian Studies. London 1910, pgs. 19- 22.

(3) Id., id., pgs. 22-27.

(4) Roscoe. The Baganda. London 1911, pg. 316. 
Según los Todas, el dios Tei Kirzi, convirtió en piedras a sus enemigos (1).

Melcart era adorado en Tiro, en forma de dos pilares (2).

En Megara, había una piedra piramidal, llamada Apolo Carino.

Zeuz Gracious, tenía en Sicyon, la forma de una piedra piramidal.

En Emesa, Fenicia, el pueblo veneraba una piedra negra, como la imagen del Sol, llamado en Fenicio, Eliogábalo.

La imagen de Afrodita, en Pafos $y$ en Chipre, era una piedra cónica, blanca; Adonis, en Biblus, era adorado en una piedra cónica.

Artemisia de Perge, en Asia Menor, está representada en ciertas medallas, por nn cono.

La imagen de Amón, era quizás una piedra cónica.

Apolo, como dios de los caminos, estaba representado por un pilar cónico.

En Delfos, había una piedra que diariamente ungían con aceite (3). En Heliópolis,

(1) Rivers. The Todas. London 1906, pg. 187.

(2) Smith. Lectures on the Religions of the Semites. London 1914, pg. 208.

(3) Frazer. Pausanias's description of Greece. London 1888, pgs. $318,355$. 
una de las incorporaciones del dios Sol, ora una piedra, lo que acontecía también en otros pueblos, por influjo de los sacerdotes de Heliópolis.

Set se creía a veces, que estaba encarnado en una piedra (1).

Ouentan los Zuñis, que hubo en tiempos muy remotos, un gran diluvio y que sus antecesores se retiraron a una meseta muy alta, mas el agna, subió tanto, que para salvarse tuvieron que sacrificar a dos hermanos, que vestidos con sus más hermosos trajes, fueron arrojados al agua; apenas consumose el holocausto, cuando principiaron a decrecer las aguas, y los muchachos se convirtieron en piedras; la hermana es todavía reverenciada, con el nombre de la madre piedra (2).

En muchos altares Hopis, se emplean planchas de piedras pintadas, con figuras simbólicas de varios colores. Una de las más notables, es la Hokona mana, o "virgen mariposa" (3).

(1) Wiedemann. Religion of the Ancient Egyptians. London 1897, pg. 154.

(2) Matilde Coxe Stevenson. The Zuñi indians, their Mythologie Esoteric fraternities and Ceremonies. 23 Annual Reaport of the Bureau of Ethnology.

(3) Fewkes. Two summer's Work in Pueblo Ruins. 22 Annual Reaport of the Bureau of Ethnology, 1900-1902. Washington 1904, pg. 104. 


\section{Religión del Imperio de los tyoas}

Tetland (tetl=piedra, $t$ tan =junto) era el nombre de un dios $y$ de un pueblo, en el señorío de Tonala (México); el origen de esta divinidad, parece haber sido una piedra oscilante, que había en la vecindad del pueblo, pero tenía carácter netamente antropomorfo, pues la representaban en figura de un hombre, que tenía una piedra en la mano (1).

Los Musos adoraban a todas las piedras, porque decían que todas habían sido hombres, pues éstos al morir, se convertían en piedras, las que un día resucitarían (2).

(1) Robelo. Diccionario de Mitología Nahoa. Anales del Museo Nacional de México, Segunda Epoca, Vol. V. México 1908, pg. 241.

(2) Fernández Piedrahita. Historia general de las conquistas del Nuevo Reyno de Granada. Amberes 1608, pg. 14. 


\section{CAPITULO VI}

\section{GUEYAS Y minAS ADORADAS}

Antes de terminar el estudio del grupo de fenómenos religiosos, que nos hemos propuesto examinar, en este volumen, réstanos exponer las supersticiones que los antiguos peruanos tenían, acerca de las cuevas, minas y otros objetos semejantes.

La adoración de las cavernas, es muy natural en aquellos pueblos primitivos, en que se venera todo cuanto parece extraordinario $\theta$ incomprensible, mas su culto puede estar basado en otros principios; sabido es cuán útiles fueron las cavernas al hombre primitivo, que en ellas estableció su morada; numerosos son los ejemplos de cuevas, que al mismo tiempo que moradas de los vivos, fueron lugar de reposo de los difuntos de la tribu salvaje, que abrigó su existencia, bajo los repliegues de la roca, así en ocasiones, la veneración de la 
cuera, puede estar basada simultáneamente en el respeto que inspiran sus antros misteriosos, ocapados quizá, por temibles fieras, en el reconocimiento $y$ apego al prístino hogar $y$ en el tributo de amor $y$ terror, que el hombre simple rinde a sus antepasados difuntos.

En todas las religiones, no han faltado quienes, inspirados por un ferviente ardor místico, buscasen en el retiro $y$ el silencio, la quietud del ánimo y la perfección interior, y las cuevas han prestado, a menudo, refugio a éstos, a quienes disgusta el bullicio mundano. La caverna que sirvió de morada a un ascota célebre, fácilmente se convierte en un templo, en un centro de culto (1).

Este origen reconocen muchos templos, en cuevas que hay en la India; quien los ha estudiado con detención, cree que su construcción fue ideada por los Budistas, pero luego adoptada por los otros credos del Indostán (2).

Muchas deidades indias, viven en cuevas, las que, así como las minas, creen que ordi-

(1) Sobre el culto a las cuevas, consúltese David Mac Ritcie, Caves en Hasting's Encycloepedia of Ethics and Religion. Edinbourgh 1910, pg. 267-70.

(2) Fergasson and Burgess. The Cave Temples of India. London 1880. 
nariamente están ocupadas por espíritus malignos.

Los Korkas de Mirzapur, cuando tienen que entrar a una caverna, se arman con flechas y hachas, para defenderse de los demonios. (Bhûts) (1).

Los Nagas dicen que Jas cueras son moradas de los lei (2).

Los Ananitas adoran al espíritu de una cuera, al cual ofrecen sacrificios, en tiempo de sequía (3).

Hay casi en todo lugar sagrado de $\mathbf{P a -}$ lestina, una gruta. En las de Fenicia se encuentran símbolos de Astrate, $y$ los más antiguos templos, en este lugar, eran cuevas (4).

En Grecia, habían cueras destinadas al culto de los dioses, en las que se veían nichos para colocar las ofrendas, tales como aquellas en que en Atenas se adoraba a Apolo y la de Demetrio Negro, en Phigalia (5).

(1) Crooke. Popular Religion and Folk lore of Northern India, Westminster 1896. Vol. I., pgs. 282-285.

(2) Hodson. The Naga tribes of Manipur. London 1911, pg. 126.

(3) Frazer. The Golden Bough, Tol I, pg. 302.

(4) Smith. Lectures on the Religion of the Semites. London 1914, pgs. $197-200$.

(5) Frazer. Pausanias's description of Greece. London 1888, Vol. II, pg, 360, IV, pg. 406, V, pg. 516. 


\section{Reliaión DeL IMPerio de los INoas}

En Abeokuta hay una cueva consagrada a Oke, en la cual creen los Egba, que en caso de ser derrotados, pueden refugiarse con toda seguridad, pues se cerrará herméticamente, mientras dure el peligro (1).

Los Sanks o Foxes, rara vez pasan junto a una caverna, sin dejar allí tabaco, para el espíritu de ella (2).

Los Apalachitas tenían una caverna sagrada, en la que hacían sus ceremonias, en honor del Sol, al tiempo de sembrar y cosechar (3).

Los indios Pueblos, acostumbraban mucho emplear las cavernas con fines religiosos. Fewkes visitó una en los montes Graham y encontró muchas pruebas de su uso antiguo, tales como bastoncitos de oración y restos de canastas; se conocen muchas otras que, claramente se ve, han sido usadas como lngares de sacrificios y nunca como habitaciones (4).

(1) Dennett. Nigerian Studies. London 1910, pg. 164.

(2) Dorman. Primitive Supertitions. Philadelphia 1881, pg. 300 .

(3) Lafitau. Moeurs des Sauvages Ameriquians. París MDCcxxiv, Vol. I, pg. 147.

(4) Fewkes. Two summers's Work in Pueblo Ruins. $22^{\text {th }}$ Annual Reaport of the Bureau of Ethnology. Washington 1904, pgs. 187-188. 
Los indios de Sonora dicen, que el sonido que sale de las cuevas, es producido por las almas que allí viven (1).

Los Haitianos hacían peregrinaciones a una gruta, de donde decían habían salido el sol y la luna y en la que se encontraban dos ídolos (2).

En cuevas, según los Quiches, vivían muchos espíritus (3).

En Ramiriqui había una caverna muy venerada, que formaba una espaciosa sala; allí los Chibchas, entre otros sacrificios, mataban niños (4).

Los súbditos de los Incas, en los caminos, cuando no podían llegar al tambo o iban por rutas que, por no ser las principales, carecían de posadas, dormían en las cuevas o machais, a las que previamente ofrecían coca y maíz mascado, para que mientras durmiesen no les aconteciese mal alguno, el que temían les

1) Dorman. Op. cit, pg. 302 .

(2) Fewkes. The Aborigenes of Porto Rico and Neighboring Islands. 25 Annual Reaport of the Bureau of Ethnology. Washington $190 \pi$, pg. 56.

(3) Dorman. Op. cit., pg. 301.

(4) Restrepo, Los Chibchas. Bogotá 1895, pg. 74. 
cansase el genio del lugar, o el alma de algán muerto (1).

Los que trabajaban en minas, adorábanlas bailando toda la noche anterior, al día en que debían dar principio a la labor.

A la divinidad, que suponían tenían las minas de oro, titulaban Coya, a la de las de plata, Mama y a las piedras metalíferas, decían, Oorpas, besábanlas y hacían con ellas otras ceremonias; reverenciaban también a las piritas, al bermellón, dicho llimpi y a las guairas a hornos, en que se fundían los metales (2).

(1) 84 Haziendo dormida en alguna cueua, sueles mascar maiz, y coca y emplastarlo en ella diziendo. Esta noche tengo de dormir en ti, adorote porque me des buen sueño, hazme soñar bien? Pérez Bocanegra. Ritual formulario e instrucción de curas. Lima 1631, pg. 134.

En los Machaes, o cuebas donde dormis de noche quando rais de camino, no ay Huaca ninguna, que sea Dios, ni que tenga poder para hazeros mal alguno, el Demonio os ha puesto miedo, $y$ por esto los Indios ofrecian coca mascada y maiz mascado, y vntaban con ella la cueba, para qne mientras dormian no les sucediera mal alguno.....el miedo le entristece, y luego imagina que el Diablo lo ha de matar, o que alguna alma de los Indios difuntos le ha de matar. Avendaño, Sermones de los Misterios de Nuestra Santa Fe. Lima, fol. 56.

(2) Usan los Indios que van a minas de plata, de oro o de açogue adorar los cerros o minas; pidiéndoles metal rico, $y$ para esto velan de noche beviendo y baylando... a los de oro llamen Coya y al Dios de las mines de plata Mama; a laspio. 
Los aborígenes de la $\mathrm{Paz}$, antigua Ohnquiapo, famosa en tiempo de los Incas, por sus lavaderos de oro, adoraban a Choque-Guanca (choke $=$ oro, huanka = galga, peñón) (1).

En el Ouzco, la sétima huaca, del segundo ceque de Chinchaysuyo, «era una cantera llamada Guayraugallay (2) que está encima de la fortaleza, en la cual hacían sacrificios por diversos respetos» (3).

En el octaro ceque de Oontinsuyo, era huaca

dras de los metales Corpa, adoranlas besando, y lo mismo al soroche, al açogue $i$ al bermellon del açogue, que llaman Sehma o Limpi. Calancha. Chronica Moralizada, Barcelona 1638, pg. 31 .

Los que iban a las minas adoraban los cerros dellas y las propias minas que llaman Coya, pidiendo les diesen de su metal; y para alcanzar lo que pedian, velaban de noche bebiendo y bailando en reverencia de los dichos cerros. Así mismo adoraban los metales que llaman Mama, y las piedras de los dichos metales llamadas Corpas besábanlas y hacian con ellas otras ceremonias; el metal que dicen Soroche; la misma plata y las guairas o brazeros donde se funde. Cobo. Historia del Nuevo Mundo. Sevilla 1892, Vol. III, pg. 345.

(1) La gente deste asiento y pueblo de Chuquiapo tenían por adoración una guaca que se llamaba Choque Guanca, que quiere decir Senor del oro que no mengua. Descripción y relación de la ciudad de la Paz. Relaciones Geográficas de In. dias, Vol. II, pg. 71.

(2) Huaira = viento, ujyay=beber.

(g) Cobo, Op, cit., Vol, IV. 
448 ReLigión DeL IMPERIO DE LOS INOAs

una cueva, a la que sacrificaban niños; llamábase Inca Roca (1).

Ourovilca (koroy $=$ cortar en pedazos, vil$c a=$ divinidad ) *era una cantera de donde sacaban piedra. Sacrificabanla porque no se acabase ni se cayesen los edificios que dellas se bacian» (2).

(1) La decima tercia se decia Incaroca. Era una cueva que estaba más adelante de las fuentes sobredichas, $y$ era adoratorio principal. Ofrecianle nif́os. Cobo. Loc. cit.

(2) Cobo. Loc. cit. Pertenencia al II ceque de Antisuyo, siendo la cuarta hurca. 


\section{N DICE}

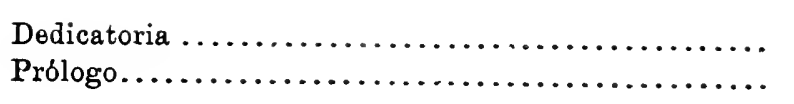

Págs.

Prólogo

VII $-I X$

\section{CAPITULO I}

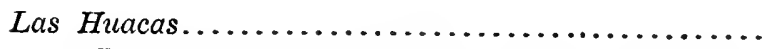

Formas de religiosidad peruanas, 1-2. Animis. mo, 3-5. Explicación de Spencer, 5-6. Animismo o naturalismo, sus condiciones, 6-10. Ejemplos de Animismo: Esquimales, Pieles Rojas, Algonquines, Iroquies, Hurones, Hidastas, Omahas, Mexicanos, Cubanos, Guayanos, Africanos, Siberia, India, Fidji, Europa, 10 19. Animismo de los peruanos, 19-29. La concepción de Mana, 29-35. Atua, 35. Andrimautira, 35-37. Hásina, 37-39. Kramat, 39-40. Muliengo, 40-41. Oudah, 4142 . Ideas semejantes del Bajo Níger, 42. Id de los Masaí, 42. Id de los Ma-rots, 43. Id Bangala. 43. Id Mayambas, 44. '1d Wangtas, 44. Id Chota Napur, 44-45. Id en China, 46. Vestigios de igual Concepción en Roma, 46-47. Manitú, 47-51. Orenda, 51-53. Wakonda, 53-59. Ideas análogas do los Hidasta, 60. Paruxti y Waruxti, 61-62. Thamanous 62-63. Ideas paralelas de los Thompson, 63. Id Lilluet, 64. Id Kwakiult, Tsimshian, Tlingit Lku' nggen, Denés y Chickasarv, 64.67. 
Cemi, 67. Naual, 67-70. El concepto primitivo Págs. del poder sobrenatural, 70-72. Análisis de la roz huaca, 72-78. Id de Vilca, 78-79. El concepto de huaca, deducido del examen de los cronistas. 79 - 84. La idea del poder huaca, 86-93. Metamórfosis, $93-97$.

\section{CAPITULO II}

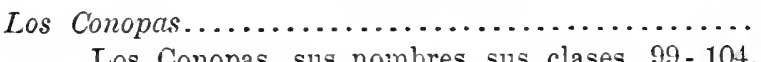

Los Conopas, sus nombres, sus clases, 99- 104. Su carácter hereditario, 105-106. Su origen, 106. Modo de invocarlos, 107-110. Naturaleza del Conopa, 110-111. Amuleto, 111-113. Amuletos esquimales, 113-120. Id Koryak, 120-126. Chukchís, 126-129. Aleutinos, 129. Kadiak, 129-131. Otros pueblos de América del N., 131 -139. Amuletos de los Pueblos, 139-144. Otros amuletos americanos, 144-149. Id Aztecas, 149-151. Id Centro americanos y Antillanos, 151-152. Id de los aborigenes de Guayana, 151-153. Id de otros Indios de Sud América, 153-159. Amuletos individualizados; amuletos genéricos, 159-173.

\section{CAPITULO III}

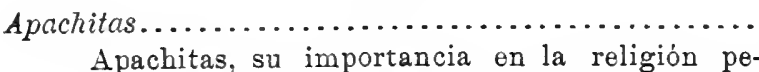
ruana, 175-176. Teorías para explicar los carines erigidos por los caminantes; suposición de Dawin, 176-177. Id de Welcker, 177-178. Id de Andree, 178-179. Id de Hartland, 179-180. Id de Leibrecht, 180. Id de Dussaud, 181. Id de Frazer, 181-182. Id de Doutte, 182. Id Dudley Kid, 183. Crítica de las teorías anteriores, 183 - 184. Carines para segar la influencia de un lugar dotado de poder nocivo, 181-200. Carines en sitios peligrosos, 200-202. Id para facilitar $\theta 1$ riaje, 203 - 201 
Id en las fronteras, 204-206. Carines para obtePágs. ner un bien, 206-208. Carines en lugares sagrados, 209 -210. Carines de causas complejas, 210-212. Carines en tumbas, 212-237. Carines $\theta$ n lugares sagrados, 237-248. Carines en muntes, 248. Sintesis del examen de las diverses clases de carines, 248-263. La concepción primitiva de fatiga, 263-264. Carines a los que no parece, a primera vista, convenir la explicación general, 264 -272. Carines fundados en magia imitativa, 272-275, Explicación de los carines erigidos por caminantes, 275-279. Apachitas modernas, 279. Cristianización de las apachitas, 280-283. Ap achitas en general, 283 . 290. Apachitas notables, 290-293. Apachitas del Cuzco, 293-296. Otras apachitas célebres. 296. Significado de la roz apachita, 296-299. Las tocancas, $299-301$.

\section{CAPITULO IV}

Montes adorados......................... $303-372$

La adoración de los montes, 303-307. La adoración de los volcanes, 307. Ejemplos de volcanes adorados, 308-321. Volcanes adorados en el $\mathrm{Pe}$ rú, 321-326. Adoración a los montes en el Perú, 326-337. Nontes adorados en el Cuzco, 338-342. Significado del culto a los montes, $342-344$. Ejemplos del culto a los montes, $344-356$. Montes divinos en México, 356-366. Id entre los Chibchas, 367. Culto a islas en el Perú, 367-372.

\section{CAPITULO $V$}

Rocas y piedras adoradas .................... $373-440$

Culto a las piedras en el Perú, 373-377. Piedras huacas del Cuzco, 377-399. Culto a las piedras en el Imperio, 399-407. Culto a piedras pre- 


\section{Religión Del IMPeRIo De los INOAS}

ciosas, 407-410. El culto de las piedras, su fun-

Págs. damento, 410 - 412. Piedras divinas en sf, $412-433$.

Piedras reliquias de un Dios, $433-440$.

\section{CAPITULO VI}

Cuevas $y$ minas adoradas .................... 441-448

El culto de las cuevas, $441-442$. Algunos ejemplos de esta adoración, $442-445$. Cuevas veneradas en el Perú, 445-446. Adoración a minas $y$ canteras, $444-448$. 


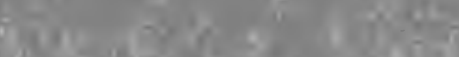

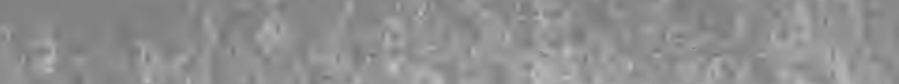

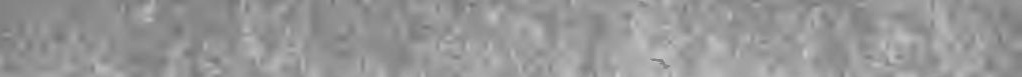

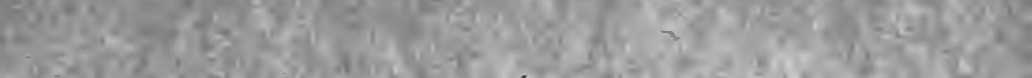

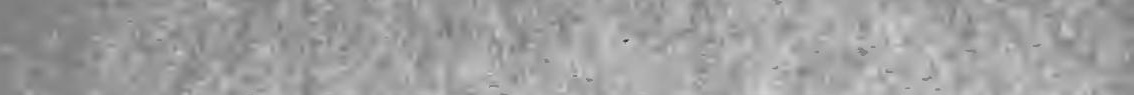

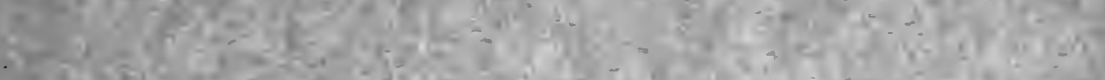

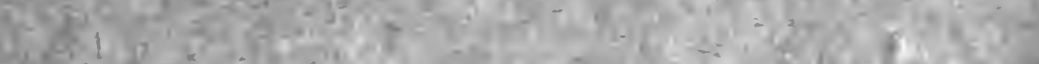

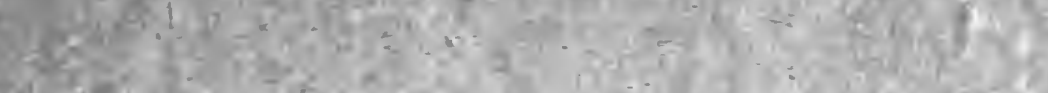

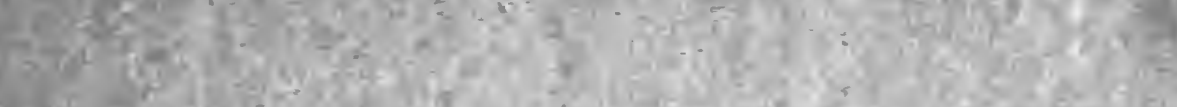

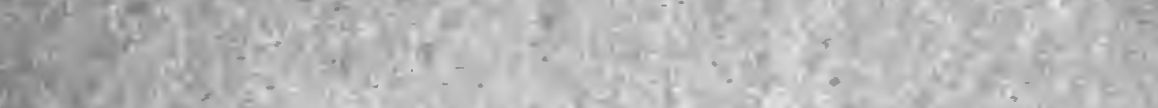

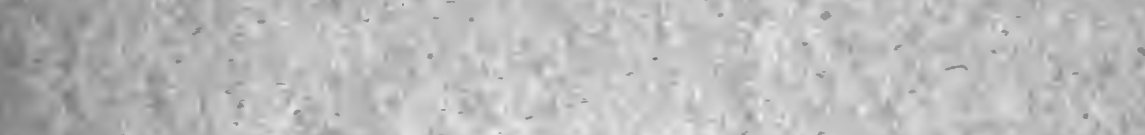

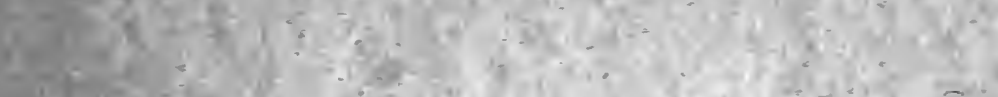

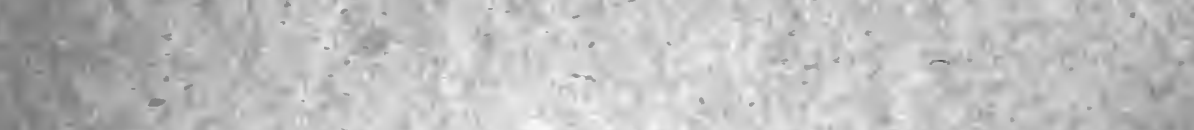

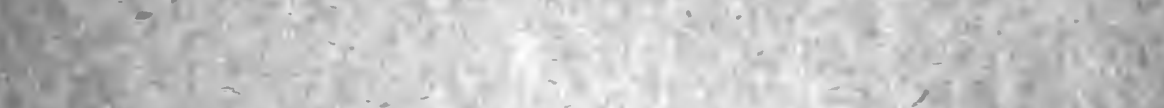

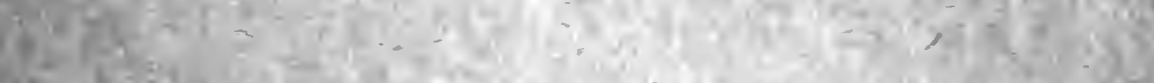

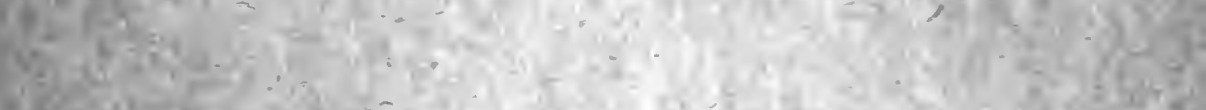

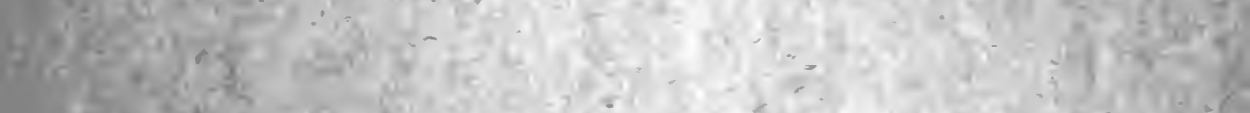

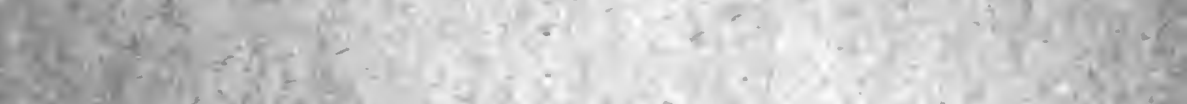

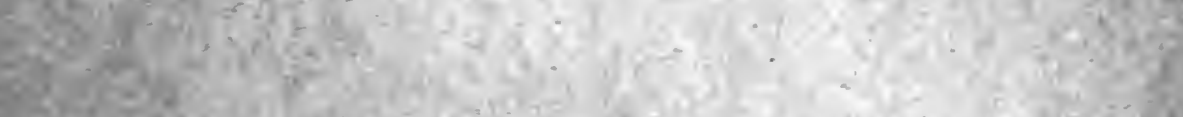

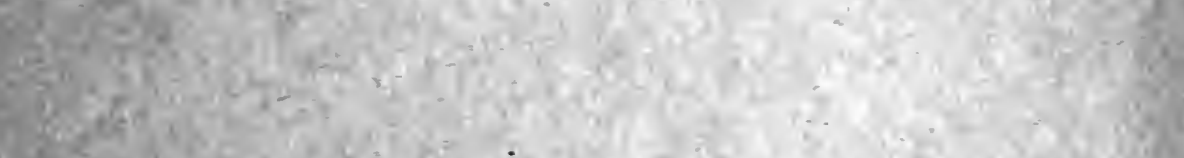

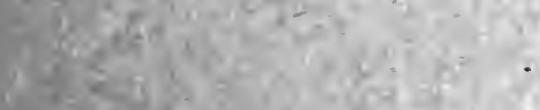

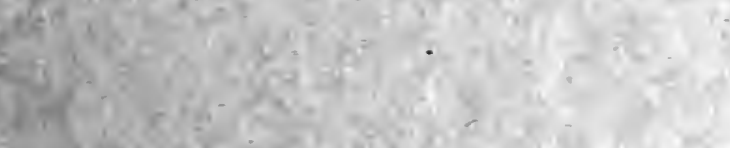

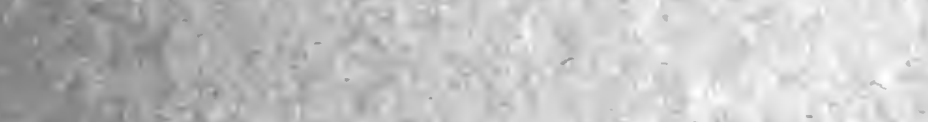

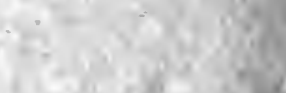

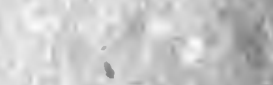

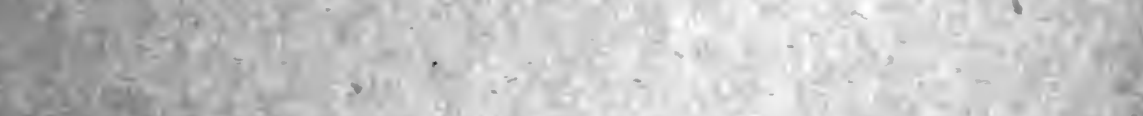

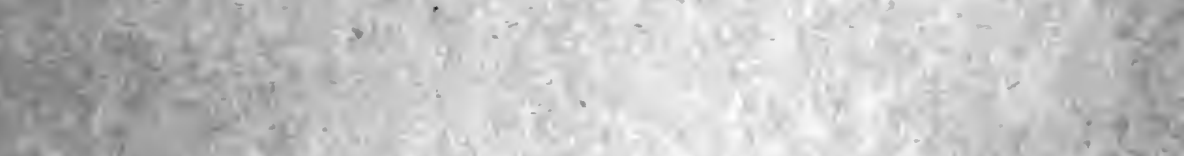

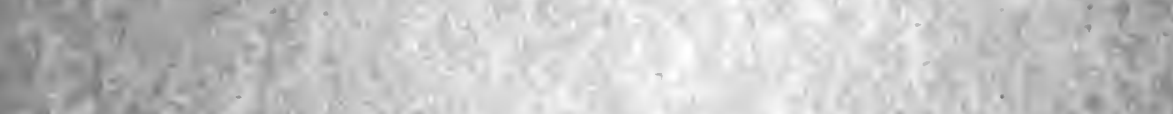

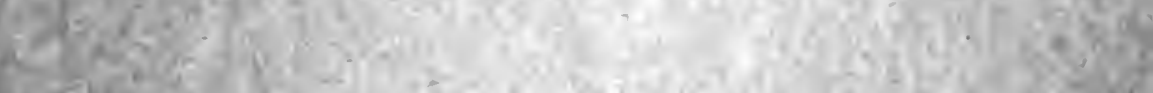

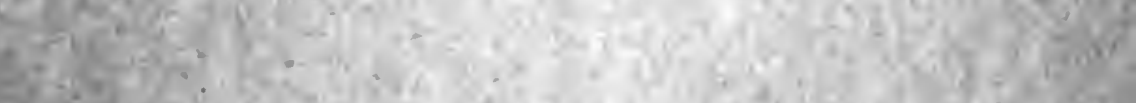

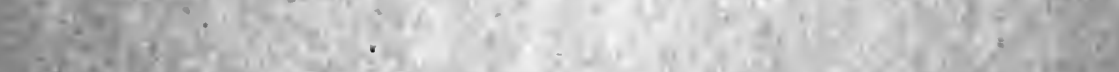

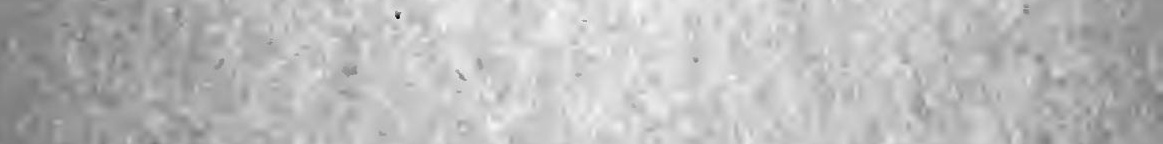

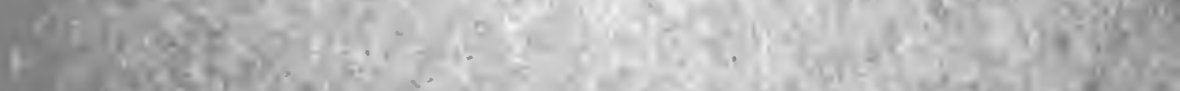
des. Fig.

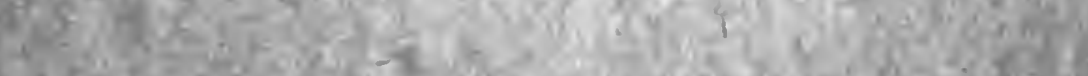

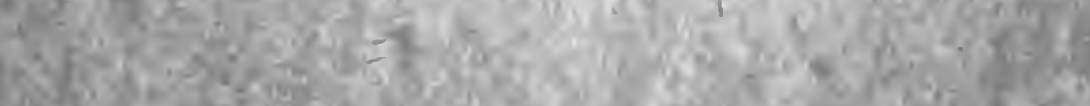

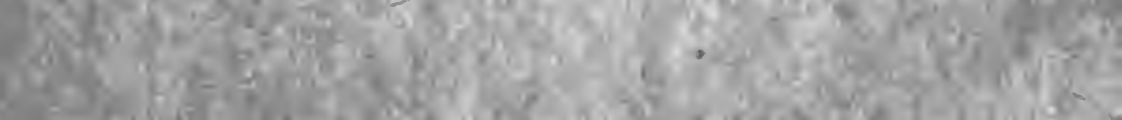




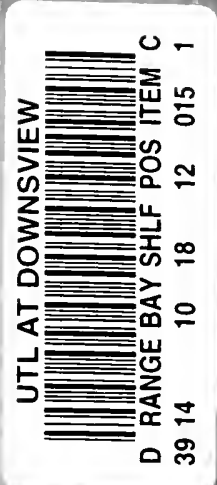

